Florida International University FIU Digital Commons

\title{
Truffles Have Never Been Modern: An Actor- Network Theorization of 150 Years of French Trufficulture
}

Eric Van Vleet

Florida International University, evanv001@fiu.edu

DOI: 10.25148 /etd.FIDC006559

Follow this and additional works at: https://digitalcommons.fiu.edu/etd

Part of the European History Commons, History of Science, Technology, and Medicine

Commons, Human Geography Commons, Nature and Society Relations Commons, Philosophy of

$\underline{\text { Science Commons, Remote Sensing Commons, Rural Sociology Commons, and the Social and }}$ Cultural Anthropology Commons

\section{Recommended Citation}

Van Vleet, Eric, "Truffles Have Never Been Modern: An Actor-Network Theorization of 150 Years of French Trufficulture" (2018). FIU Electronic Theses and Dissertations. 3679.

https://digitalcommons.fiu.edu/etd/3679 
FLORIDA INTERNATIONAL UNIVERSITY

Miami, Florida

TRUFFLES HAVE HEVER BEEN MODERN: AN ACTOR-NETWORK THEORIZATION OF 150 YEARS OF FRENCH TRUFFICULTURE

A dissertation submitted in partial fulfillment of the

requirements for the degree of

DOCTOR OF PHILOSOPHY

in

GLOBAL \& SOCIOCULTURAL STUDIES

by

Eric Van Vleet 
To: $\quad$ Dean John F. Stack, Jr

School of International and Public Affairs

This dissertation written by Eric Van Vleet, and entitled Truffles Have Never Been Modern: An Actor-Network Theory Description of 150 Years of French Trufficulture, having been approved in respect to style and intellectual content, is referred to you for judgment.

We have read this dissertation and recommend that it be approved.

Terrance Peterson

Benjamin Smith

Roderick Neumann

Gail Hollander, Major Professor

Date of Defense: January 18, 2018

The dissertation of Eric Van Vleet is approved

Dean John F. Stack, Jr School of International and Public Affairs

Florida International University, 2018

Andrés G. Gil

Vice President for Research and Economic Development and Dean of the University Graduate School 


\title{
ABSTRACT OF THE DISSERTATION \\ TRUFFLES HAVE NEVER BEEN MODERN: AN ACTOR-NETWORK \\ THEORIZATION OF 150 YEARS OF FRENCH TRUFFICULTURE
}

\author{
by \\ Eric Van Vleet \\ Florida International University, 2018 \\ Miami, Florida \\ Professor Gail Hollander, Major Professor
}

Contemporary scholars seeking to increase Tuber Melanosporum truffle

production rely almost exclusively on technological advancements to increase yields, while failing to place the cultivation of truffles, trufficulture, in its historical or local landscape contexts. In this dissertation, I describe how truffle scholars' conceptualization of trufficulture and landscapes has changed over 150 years in France, while focusing on the French département of Lot. I examine changing relations between humans and nonhumans and how they impact truffle harvests. I analyzed the history of French trufficulture through a close reading of historic truffle manuals, archival research and the classification of remotely sensed images. Shifting from the past to the present, from July 2014-August 2016, I conducted semi-structured survey interviews with working trufflegrowers (trufficulteurs) and participant observation at meetings of trufficulteurs, truffle hunts and truffle markets. I utilize actor-network theory (ANT) as both a theory and methodology. Actor-network theory allowed me to follow the impacts made by both humans and nonhumans on trufficulture. I found that truffle harvests in the $1880 \mathrm{~s}$ dropped by $90 \%$. Highly populated, intensively worked landscapes of viticulture, 
silvopastoralism and cereal cultivation created conditions suitable to truffles. By the 1870s the phylloxera aphid ravaged grapevines, which made trufficulture an important source of revenue. These advantageous conditions would not last. Post-WWI, yields fell for decades because of an ongoing rural population exodus and consequent agricultural abandonment, which promoted reforestation and closed canopy forests in Lot, France. By the 1960s, French trufficulteurs organized associations to share knowledge and promote local truffle markets to revive production. Trufficulteurs 'utilization of tractors, inoculated plants and irrigation systems produced a new form of modern trufficulture. State subsidies helped trufficulteurs adopt modern practices, in hopes of increasing yields. Modern trufficulture has not dramatically increased yields. A few highlycapitalized trufficulteurs dominate production in Lot. Many others practice trufficulture as a hobby. Instead of relying on modern technological fixes, my findings suggest that trufficulteurs, farmers and states should reinvigorate extensive polyculture farming practices that maintain open canopy forests, which were beneficial to trufficulture in the past. Actor-network theory allowed me to rethink human and nonhuman relations, and to propose alternatives to modern trufficulture. 


\section{TABLE OF CONTENTS}

CHAPTER

Chapter 1: Dissertation Introduction

Introduction

Dissertation Objectives

Topic and Research Site Selection

An Introduction to Truffle Ecology

Overview of Fieldwork

Participant Observation 19

$\begin{array}{ll}\text { Semi-Structured Survey Interviews } & 20\end{array}$

Archival Research $\quad 25$

Remote Sensing $\quad 31$

Dissertation Organization $\quad 35$

Chapter 2: Examining ANT's Theoretical and Methodological Strengths 39

Chapter Overview $\quad 39$

Introducing ANT $\quad 39$

Common Critiques of ANT $\quad 41$

Describing ANT's Fundamental Sensibilities 43

$\begin{array}{ll}\text { Relational Effects } & 44\end{array}$

Human and Nonhuman Actants $\quad 44$

$\begin{array}{lr}\text { Actor-Networks } & 48\end{array}$

Materiality $\quad 50$

Stability and Instability in Actor-Network $\quad 51$

The Local Versus the Global $\quad 53$

Power in Actor-Networks

Symmetry of Actants and Outcomes $\quad 56$

ANT as Method $\quad 58$

Where, When and How to Begin Describing Actor-Networks? 61

How to Follow Both Humans and Nonhumans? 65

Vocabulary, Reflexivity and Power in ANT 68

My Treatment of Reflexivity and Power in Truffle Actor-Networks 72

Chapter 3: Lot's Tumultuous Golden Age of the Truffle 78

$\begin{array}{ll}\text { Introduction } & 78\end{array}$

$\begin{array}{ll}\text { Describing the Département of Lot } & 78\end{array}$

Lot's Changing Wine Economy 80

An Overview of Lot's Agrarian Economy $\quad 81$

$\begin{array}{lr}\text { Farming Lot's Causses } & 84\end{array}$

"Wine Madness" $\quad 85$

The Ravages of Phylloxera in Lot 88

The Invention of Trufficulture in Lot in the Wake of Phylloxera 95

Describing the Golden Age of Trufficulture in Lot 100 
The Effects of Sheep and Per Hectare Yields

Chapter 4: The End of Lot's Truffle Golden Age: Economic Competition, Agricultural Abandonment, Rural Exodus and Forest Resurgence.

The Beginning of the End of Lot's High Truffle Production 124

Rural Exodus

World War 1 Causalities and Birthrates

Chapter 5: The Development of Modern Trufficulture and Its Fluidity in Lot 156 Introduction 156

Inoculated Plants: When Trufficulture Becomes Modern 157

Problems with Inoculated Plants 158

In Situ and Ex Situ Fungal Contamination 160

The Costs of Modern Trufficulture 164

A Changing Truffle and the Loss of Virulence 166

Geneticists' Understandings of Tuber melanosporum 167

Chemists' Understanding of T. melanosporum 170

Implementing Modern Trufficulture in Lot 172

General Description of Trufficulteurs 173

Truffle Ecology 174

The Decline of Truffle Production in Lot 181

The Political Economy of the Truffle 186

Trufficulteurs' Prognostications 194

Discussion 197

Chapter 6: Discussion $\quad 204$

Introduction 204

Lot's Truffle Golden Age 204

The End of the Golden Age 212

The Development of Modern Trufficulture 218

Recommendations for a Nonmodern Trufficulture 226

Broader Implications of ANT as Seen Through Trufficulture 235

Works Cited 244

General Works Cited 244

Archival Works Cited 254

Survey Interviews Cited 257

$\begin{array}{ll}\text { Appendix } & 263\end{array}$

$\begin{array}{ll}\text { VITA } & 260\end{array}$ 


\section{LIST OF TABLES}

$\begin{array}{ll}\text { TABLE } & \text { PAGE }\end{array}$

1. The Impacts of Phylloxera and Its Remedies in Lot 91

2. Lot's Truffle Harvests 1901-1920 103

3. Truffle and Forest Mushroom Production in Lot from 1900-1932 105

4. Lost Truffle Revenue from Sheep in the Canton of Martel, Lot 109

5. Hectares of Truffières and Production in 1915 for the Arrondissement of Gourdon

6. Limogne Truffle Market 1913-1923 115

7. Hectares of Forest and Field Areas from Cartes de Cassini 146

8 Hectares of Forests and Fields from the L'Etat Major Maps 147

9. Changes in Land Cover from 1948-2000 148

10. Changes in Forest Cover Percentages from Cassini to 2000 


\section{LIST OF FIGURES}

$\begin{array}{ll}\text { FIGURE } & \text { PAGE }\end{array}$

1. Truffle Production in the Arrondissement of Gourdon 126

2. Population Trends in Lot from 1790-2013 130

3. Births vs. Deaths in Lot from 1846-1923 140

4 Classified Communes in Lot, France 145

5. Land Cover Change in Lalbenque 1948-2000 150 


\section{Chapter 1: Dissertation Introduction}

\section{Introduction}

When I began researching French trufficulture for this dissertation in June 2014, I imagined that I would chronicle in as much detail as possible the practices of contemporary trufficulteurs, scientists, plant nurseries technicians and politicians. I wanted to capture trufficulture as it was being practiced in this moment. Lot, France, with its active syndicate and associations of trufficulteurs (truffle farmers), touristic markets and truffle festivals and rich history of trufficulture, seemed like an ideal research site. In Lot, a fascinating host of actants were trying to restore the truffle's actor-networks to stabilize if not increase production. Yet despite a group of creative, passionate and hardworking people, truffle yields have remained low in Lot. Understanding today's underwhelming yields initially led me to search for the living culprit(s).

Like many contemporary works on trufficulture, I initially assumed that there were too many uncertainties and unpredictable actants in contemporary trufficulture in Lot to seriously focus on the past. Today's actor-networks seemed unsettled enough. Only a few other scholars had deemed this past was worth investigating in detail (Bye 2000; Castelnau 1978; Champagnac 2000; Chazoule 2004; Diette and Lauriac 2005). Most contemporary works on trufficulture merely noted a few details about trufficulture a century ago. They admitted that current yields were $95 \%$ less than those of the early 1900s, but spent little time analyzing these past actor-networks (Callot 1999; Olivier et al. 2012). After a brief recap of the last 150 years in trufficulture, they returned to what was for them, the far more engrossing present. 
I found this relative disinterest in the past shocking, especially as truffle yields were almost imaginably high at as much as 2000 tonnes compared to 35 today (Callot 1999). It seemed short-sighted to try to "relaunch" (Champagnac 2000) or restore truffle production if one did not understand roughly the period of 1870-1914 that saw its greatest success, one that Chazoule (2004) has labeled the "golden age" of trufficulture.

I realized that trufficulteurs in Lot were still practicing trufficulture in the same communes with the same host tree species in hopes of producing the same truffle species Tuber melanosporum as they had 150 years ago. Interviewing contemporary trufficulteurs helped me realize that many in Lot had familial histories of trufficulture and were working the same plots as their parents or grandparents. Even when they practiced similar techniques as those of their grandparents, today's results were disappointing in comparison. Techniques had stayed relatively the same, yet today's yields were one to five percent of what they were 100 years prior. These disparities between past and present truffle yields drove me to explore in as great of detail the truffle's past in Lot.

I did not assume the past and present to be automatically connected or disconnected. Actants could sustain or relinquish associations throughout time, modifying actor-networks in turn (Latour 1993). Too many other contemporary truffle scholars have read the classic manuals like Bosredon (1887), Chatin (1892) and Pradel (1914) as historic curiosities. I read them as vital documents that would help to reconstruct past practices and associations. I admired these works as they diversely discuss trufficulture, truffle markets, phylloxera and deforestation as actor-networks in relation. They inspired the expansive nature of this dissertation. 
Unlike other scholars investigating trufficulture who were biologists, ecologists or from the other "hard" sciences, I have investigated the history of trufficulture through a human geography lens and more specifically with actor-network theory (ANT) as my guide. With ANT's assistance, I could pay attention to multiple actants and agencies, human and nonhuman as well as their "hybrid" combinations. ANT led me to consider both how humans and nonhumans had combined to transform trufficulture over time. Furthermore, ANT guided me to examine the strength of different associations, which greatly influenced the temporal and spatial scales of my investigation. I soon realized that understanding contemporary trufficulture actor-networks would mean that I traced actants for at least 150 years in the past. In Chapter 2 I discuss at length ANT as a theoretical and methodological framework for this dissertation. It is a vast body of scholarship. In Chapter 2 I situate my study within it.

I believe that by using ANT as my guide in exploring trufficulture past and present, I have produced novel results, results that would have not come but treating trufficulture historically or in its contemporary iterations as by being intrinsically separate or divided. Yet in describing the continuities and discontinuities in trufficulture in Lot over the past 150 years is no simple task. ANT opens almost infinite possibilities for the researcher. Such openness can be a blessing or potentially a curse. Spatial or temporal scales are not set (Latour 1996a, 1999). Researchers cannot assume any entities are actants. Actants must affect others and make effects (Latour 2005). Actants' ontologies are only established in their relations (Law 2004). One cannot merely fit events inside of preexisting contexts (Latour 2005). Such demands increase the investigator's labor as they go looking for the traces of and following multiple actants 
across time as they create context. Such pursuits are not simple. They lead to rich descriptions in a kind of time consuming "slowciology" (Latour 2005). Still, I hope the openness that ANT provides has allowed me to view and review the truffle's history in novel ways. I hope to blaze new trails with ANT. With ANT I offer alternatives to current directions in trufficulture.

\section{B. Objectives of this Dissertation}

This dissertation seeks to demonstrate how the construction of trufficulture, the ability of people (trufficulteurs) to actively cultivate truffles like wheat, grapes or other crops, is far more than a mere question of technological innovation or human mastery of the truffle. The story of trufficulture features no clear narrative of heroic scientific progress. Much is accidental. Instead of complying with human intentionality, I detail how trufficulture is not transformed solely through human agency. Nonhumans consistently aid and sabotage trufficulteurs. One cannot easily separate desirable and undesirable humans and nonhumans in trufficulture actor-networks.

Instead, trufficulture is a fascinating "hybrid" of human and nonhuman agency (Latour 1993). Even by the 1860s some hoped that trufficulture would become as predictable and potato cultivation (Rémy 1861). A 2007 truffle manual entitled Taming the Truffle continues these hopes (Hall et al. 2007) a century and half later. Yet, during this 150 -year period, truffle cultivation rapidly rose to historic heights by 1910 , plummeted from 1930-1980 and by the 1990s began to stabilize (Callot 1999).

Despite continued hopes of scientific mastery, the truffle has never been "tamed" or "domesticated" (Bye 2000; Hall et al. 2007). While truffle scholars have hoped to move it across the "Great Divide" that separates nature and culture (Latour 1993), such 
victories have been fleeting (Bye 2000). Early on I realized that truffle had never been "modern" in the sense of being purely a product of human culture or a nature that was transcendent of culture (Latour 1993). Furthermore, it was intimately linked to past and current land uses far more than many other crops. It defies "purification".

Yet if it was a "hybrid" of what is commonly called nature and culture, I must describe exactly what kind of "hybrid" it is and how such hybridity morphs and takes shape. Latour (2005) argues that an ANT study is judged by the richness of its descriptions of actants and not its ability to jump quickly to answers or seek outside explanations. Following this advice, I tried to traverse the truffle world describing in the finest detail possible its fascinating history. I sought to understand the actants that produced the truffle's meteoric rise in production and the causes of its brutal decline.

Instead of merely faulting scientists or trufficulteurs for their lack of hard work, determination or skill, I became convinced that the story was much more complicated. I realized with the help of ANT that the agency of different humans and nonhumans has dramatically changed over these 150 years. Above all, truffle landscapes, their species relationships and human interventions, were revolutionized throughout the 20th century. My classification of remotely sensed images shows just how profound these landscape changes were. Without any clear decision or policy trajectory to make them so, these landscapes become increasingly less suitable to trufficulture. The truffle and trufficulture were all but abandoned from the 1940s to the 1970s. When people again become interested in the truffle in the 1970s, they were engaging in what was termed "modern" trufficulture (Callot 1999) in different actor-networks. 
My readings of ANT convinced me to look beyond human action and understand how nonhumans had shaped trufficulture. An army of nonhumans soon appeared from other fungi that competed against the winter black truffle (Tuber melanosporum) in forming relations with a host tree species, to wild boars and deer that would damage these trees and upturn the soil and hurt truffle production, to how the phylloxera epidemic that nearly killed French viticulture had prepared these landscapes for trufficulture. In the history of the truffle, little is predictable.

In ANT, actants do not need to demonstrate intentionality (Callot 1984). I do not claim to understand the intentions of nonhumans or even claim that they are knowable. Instead, I demonstrate that they produce effects, the traces of which I followed through archives and interviews. At the same time, I realized that human intentionality had its limits as well. The actor-network became an increasingly strong framework to understand massive changes in a system without anyone or anything guiding these changes or even intentionally producing them.

Apropos of ANT, the more I studied ANT the less capable I became of "purifying” human and nonhuman actants. It became increasingly difficult to imagine when the truffle would be made "modern" and predictable (Latour 1993). Trufficulture becomes a story without any clear teleology or progress. Such stories appear more and more accurate to the actual outcomes of "modernization" than the fictions recounted about modernization (Tsing 2015). Trufficulture cannot realistically recreate the actornetworks that produce its productive heights, nor is there a clear direction for the future. Only the complicated work of assembling new and unpredictable actor-networks remains.

\section{Topic and Research Site Selection}


My introduction to the truffle lacks the romance that many anthropologists describe when first encountering their research subject. While searching for the topic of my dissertation, my friend and then classmate Evan Cook sent me a YouTube link to a 60 Minutes story about the secrecy and 'deception' in French truffle markets (CBS News 2012). Ironically people at my research site in Lot, France later would tell me to watch the same link as it featured a local Lotois truffle merchant.

The clip immediately captivated me. The truffle's story contained elements of crime, deep questions of provenance, celebrity chefs, pigs and dogs and a world growing hungrier for truffles. With such rich material, I was convinced I could assemble a rich dissertation about the truffle. As they seemed to be the most skilled promoters of their truffle image and heritage, I decided to study the truffle in France.

With my limited French language skills, I began to search for a research site. Yet, initial research indicated that the French truffle industry was indeed an extremely secretive business (de la Pradelle 2008). I realized I could not just arrive in market towns like Lalbenque, Richerenches or Sainte Alvère and charm truffle growers, trufficulteurs with my YouTube French. I needed official contacts.

I learned that trufficulteurs, like most farmers, had formed growers' associations/syndicates. I began to email these groups in Vaucluse, Dordogne and Lot. I only received a reply from the secretary of Lalbenque's Truffle Syndicate, Daniel Escribano. Once I provided Daniel with my dates for preliminary research, he quickly responded that he had contacts for me in Lot. He even arranged a room in the home of a local family that would house me for my first few weeks. This welcoming and hospitable email from Daniel brought me to Lot. 
This connection with the Lalbenque Truffle Syndicate allowed me to begin "tracing" the truffle's actor-network there. I was invited to attend truffle syndicate meetings in Lalbenque, Lot and from the region. That first summer the president of the national truffle association visited Lalbenque. I realized that Lot was if not at the "center" of the truffle's actor-network, it was a place where important actants associated.

Daniel also introduced me to the département's leading truffle technician Pierre Sourzat. Pierre invited me to his workplace, the experimental truffière at La Station Trufficole at the Le lycée des territoires Cahors-Le Montat, where I met other technicians and truffle enthusiasts. The next winter he allowed me to participate in a short course given to aspiring trufficulteurs at Le Montat. He was instrumental in arranging my semistructured survey interviews. He also accompanied me on these interviews, where we each recorded participants responses. His support was transformative.

These contacts further convinced me that Lot, France was an ideal site to understand French trufficulture. Lot had an active truffle syndicate in Lalbenque and an association in Martel and a departmental syndicate, while its trufficulteurs were active at both the regional and national levels of truffle organizations. Truffle technicians at Le Montat were important actants who not only acted as extension agents for local trufficulteurs, they taught courses on trufficulture, produced and sold inoculated or mycorrhized saplings, gave tours to tourist groups and even produced original research that they published and distributed. The link between Lalbenque's truffle syndicate and Le Montat was close as well as technicians from Le Montat helped manage the syndicate's experimental truffle farm. 
Subsequent time spent in Lot demonstrated that the départemental archives were a rich source of documents about historical truffle yields, viticultural history, agricultural policy and history, population trends and landscape change which would shape my thinking and the direction of this dissertation. Upon reading 19th century manuals I learned that Lot was frequently among the top three truffle-producing départements in all of France (Chatin 1892). Yet few départements saw their production fall as dramatically during the 20th century (Champagnac 2000). Therefore, while many contemporary trufficulteurs in Lot were hoping for a renaissance of truffle production, Lot as well had a deep truffle history. Explaining the disparity of truffle yields in Lot between now and the early 20th centuries became an obsession that drove much of my work.

What was particularly rich about Lot for my research interests was not only that they had experienced a "golden age" (Chazoule 2004) of truffle production, but that production had so markedly declined before trufficulteurs there tried to remake truffle actor-networks. More fascinatingly, trufficulteurs have not merely been able to succeed in "taming the truffle" (Hall et al. 2007) through technological advancements. History was not on trufficulture's side in Lot. Massive reforestation, agricultural abandonment, increasing competition for its agricultural products and a rural exodus all have helped make the Lot's landscapes less favorable for truffle production. Therefore, I argue throughout this dissertation that it is impossible to argue that humans or nonhumans alone have been responsible for successful or unsuccessful truffle harvests. Instead truffle yields have a distant hybrid actor-network. Lot is the ideal place to describe these constantly changing actor-networks.

\section{An Introduction to Truffle Ecology}


This dissertation is an in-depth examination of trufficulture and its changing actor-networks in Lot, France. Therefore, here I will provide a summary of some fundamental aspects of trufficulture and truffle ecology. While records indicate that humans had harvested truffles for hundreds of years, it was only in the 19th century that serious work began about how to cultivate them through what became known as trufficulture. Trufficulture revolutionized truffle production and commerce (Chatin 1892).

Prior to the development of "artificial" trufficulture and the subsequent search of planting of trees specifically for truffle production, farmers often helped maintained "natural" truffières in an open canopy state through the harvesting of fuelwood or silvopastoralism (Castelnau 1978). Even if these so-called "natural" truffières (De le Bellone 1888) were managed landscapes with consistent human intervention to favor truffle production, they were not necessarily managed with truffle production as their first goal (Rey 1889). A common practice was harvesting truffles at the forested edge of active pastures (Delpon 1835). Instead of existing somehow outside of anthropogenic disturbance, these "natural" or "spontaneous" truffières were unplanted forests, while "artificial" truffières were planted in straight rows specifically for truffle production. Understanding the conditions of these "natural" or "spontaneous" truffières was vital to understanding how one could cultivate truffles (Meulet 1889). While some hoped to dramatically extend the range of trufficulture beyond the range of "artificial" truffières to other countries entirely (Ravel 1857), most argued that one could only incrementally "extend" the range of "natural" truffières through nearby plantings of "artificial" truffières in regions with many "natural” truffières (Chatin 1892; Pradel 1914). 
With the development of trufficulture in the 19th century there was a concerted effort to mimic the conditions found in so-called "natural" or "spontaneous" truffières with the hope of replicating these conditions in "artificial" truffières to increase winter black truffle (Tuber melanosporum) production throughout France (De le Bellone 1888; Meulet 1889). While these techniques were 'discovered' by the roughly 1815 , they did not spread rapidly (De le Bellone 1888). Still, by the 1850s trufficulture was presented at a World's Fair (Valserres 1874). Trufficulteurs by the 1860s began to reforest on largescales with the intent to produce truffles (Pradel 1914; Valserres 1874). Government officials argued that subsidies given to trufficulteurs to replant with its host species would provide income to poorer areas while reforesting lands (Pradel 1914).

Truffle scholars began to understand necessary conditions for trufficulture, which included the existence of truffle spores in the soil and 'native' host trees usually oaks (Quercus ilex) and (Quercus pubescens) (Chatin 1892; Mouillefert 1904). Yet the ontology of the truffle resulted from a prolonged debate (Grimblot 1878; Chatin 1892). Both Ravel (1857) and Valserres (1874) were vocal and skilled spokespersons for the idea that the truffle was a growth from a tree's roots resulting from the bite of the "truffle-generating fly" (mouche truffigène).

While Valserres (1874) could "interest" many truffle-growers (trufficulteurs) to support his case (De le Bellone 1888), a host of scholars were able to utilize improved microscopes as well as cite the work of important European mycologists to support the idea of the truffle as a hypogenous mycorrhizal mushroom (Bonnet 1869; Bosredon 1887; Chatin 1892; De le Bellone 1888; Pradel 1914). They argued then that the truffle created symbiotic relationships by connecting its mycelium with the roots of its host tree 
(Pradel 1914). Creating and maintaining the conditions ideal for this symbiosis between tree and spores became paramount if "artificial" trufficulture was possible (Chatin 1892; Pradel 1914). The truffle as a mycorrhizal mushroom would gain paradigmatic status in the coming decades.

Compared to "natural" truffières, which were unevenly spaced and often sparsely populated with producing trees, "artificial" truffières were planted in evenly spaced straight rows and columns (De le Bellone 1888). These evenly spaced plantings made truffle hunts with trained pigs and dogs that much more efficient. It also allowed one to maintain the plantation spacing to favor the truffle (Chatin 1892). While "artificial" trufficulture originally relied on planting acorns directly in the ground from trees which were good producers (Bosredon 1887), scholars increasingly advocated for nursery techniques and the transplantation of saplings on site (Mouillefert 1904; Pradel 1914).

Pradel (1914) explains that trufficulteurs were supposed to recognize that certain saplings have a special "aptitude" for producing truffles, which should be true of the acorns of the productive trees. Yet choosing acorns from productive trees was not in itself sufficient (Grimblot 1878). If one planted these "apt" trees then one could reach almost $100 \%$ production, while in methods of merely sowing acorns in the ground, one often had only $40 \%$ of trees that would produce (Pradel 1914). Having the skill to recognize this “aptitude" became paramount (Pradel 1914).

Trufficulteurs needed to plant these "apt" trees in the proper ground as well, which needed to be calcareous, poor in nutrients, with shallow soil and permeable subsoil (Boulanger 1906). Such lands were marginal for all other crops save for grapevines. Often trufficulteurs would grow grapes and truffles together to increase revenues as well 
as to create ideal conditions for truffles (Bosredon 1887). The ideal land use history for planting a truffières was an old vineyard (Pradel 1914). The parts of the garrigues of the southeast France and the causses in places like Lot were often ideal for viticulture as well as trufficulture (Mouillefert 1904; Valserres 1874). Here we can see the successful trufficulteur needed to develop considerable savoir-faire in selecting "apt" soil conditions and trees (Pradel 1914). Chatin (1892) argues that one could ensure production under proper conditions by "seeding" the ground with truffle spores, which were methods that he called "direct" truffle cultivation.

Even with selecting "apt" trees and "seeding" soils, trufficulture needed other techniques to ensure production (De le Bellone 1888). One important factor was retaining an open forest canopy which allowed the penetration of sunlight to decrease soil humidity and exchange of atmospheric gases with the soil. Trufficulteurs then would need to prune tree branches to help maintain these conditions as the planted trees grew (Bosredon 1887). Failure to correctly prune trees could lead to the cessation of truffle production, either by pruning too conservatively or too liberally (Brunet 1902). Many believed that pruning trees in a reverse cone shape as well as controlling the vertical growth of the tree would favor horizontal root development and more potential to connect with the truffle's mycelium (Bosredon 1887; Brunet 1902; Pradel 1914). Trufficulteurs pruned their trees by hand. These pruned branches could be used for animal fodder or fuelwood, both which peasants needed (Bosredon 1887).

Next, truffle scholars argued that to practice trufficulture one must plow or work the ground before and often during production (De le Bellone 1888; Pradel 1914). While some would plow ox-driven plows that they would use on other fields, others did this 
work by hand (Bosredon 1887). Pradel (1914) emphasizes that this work was necessary to cut the tree's roots, which would favor the kind of root tip development that was favorable for the truffle's mycelium. If one did not sever these roots, then the ground would become saturated with old roots that could "asphyxiate" a truffière. Both pruning trees and working the ground could help the truffière begin to produce as early as 4 years but often after ten years. It would also prolong the productive life of a truffière. Often, they would produce for more than 20 years before they would be uprooted and replanted (De le Bellone 1888; Valserres 1874). In rare cases, individual trees often in "natural" truffières could produce for over 100 years (Chatin 1892).

Clearly Tuber melanosporum demands specific ecological conditions and frequent human interventions both to the tree and the soil to transform a mere plantation of oaks into a truffière (Mouillefert 1904). Based on these interventions scholars argued that the above techniques changed truffles from being a foraged item to one produced through agricultural techniques (trufficulture). Truffle scholars argued that these techniques led to a new "culture", "artificial" trufficulture a new kind of farmer, the trufficulteur (De le Bellone 1888). Without these interventions, conditions in a truffière would become less suitable to the production of Tuber melanosporum (Pradel 1914; Valserres 1874). Therefore, humans not only needed to plant truffières, they needed to try to maintain specific actor-networks to help them produce and continue to produce. Yet such maintenance only lasted roughly half a century (Chazoule 2004).

In fact, between 1914 and the 1970s many truffières were abandoned. These truffières increasingly became sterile. Overall, production plummeted. It seemed that the truffle could disappear in place like Lot as fewer and fewer people planted new or 
maintained existing truffières (Castelnau 1978; Champagnac 2000). By the 1970s a dedicated group of truffle scholars and trufficulteurs attempted to restore production through "modern" methods (Callot 1999). While they adopt many of the historical methods of "artificial" trufficulture from the end of the 19th and beginning of the 20th century, like producing trees in nursery conditions, replanting them in uniformly spaced plantations, regularly trimming trees and working the soil (Chatin 1892; Pradel 1914), they have also adopted tools from "modern" agriculture such as irrigation systems and tractors (Champagnac 2000; Olivier et al. 2012).

Novel developments in truffle science such as the mycorrhization/ inoculation of host trees allowed laboratories to mimic truffle spore/ host tree symbiosis (Olivier et al. 2012) proved revolutionary. These plants helped stimulate interest in trufficulteur, interest which had long been waning (Champagnac 2000). With the production of inoculated plants on the rise, scholars hope to reverse truffle declines of over $90 \%$ over the last century (Callot 1999) and restore or "relaunch" trufficulture in areas with high historical production (Champagnac 2000). Yet thus far yields have only stabilized under the different proposed models of modern trufficulture (Sourzat 2009). No panaceas have emerged, despite the dramatically increased costs of "modern" trufficulture methods (Mayssonnier 2010). Here I investigate why the truffle has remained so mysterious even after nearly 150 years of scientific inquiry (Bonnet 1869; Olivier et al. 2012).

\section{E. Overview of Fieldwork}

During Spring 2014 I had made contacts with members of Lalbenque's Syndicate of Trufficulteurs, who invited me to Lot to present my research to syndicate leaders. After gaining their support, I began my fieldwork in Lot in the summer of 2014. During my 
first trip, I remained in Lot from May until August. I spent the first two months of the summer of 2014 familiarizing myself with the area and improving my French language skills. During this period, I attended meetings of truffle associations and syndicates at the communal, départemental and regional levels. At these meetings I conducted participant observation, which I will explain in further detail later. During this same period. I began editing my survey with a local truffle extension agent, Pierre Sourzat. I will describe these survey methods in greater detail in a subsequent section. I have included the survey questions in an appendix to this dissertation. I will report the results of these surveys in Chapter 5 of this dissertation. After having tested this survey instrument, we began conducting semi-structured household survey interviews in July and August 2014. Pierre also provided me with some of the classic manuals of trufficulture, such as Bosredon (1887) and Chatin (1892). The results from these surveys and the fascinating historical details in these truffle manuals led me to expand the research from a contemporary investigation to a historical one as well.

I returned to Lot in December and January 2014-2015. During this period, I first visited Lot's département archives in Cahors, gained access the archives and communicated with archival staff about my research interests. I conducted two weeks of archival research during this period primarily to understand the holdings and plan future research there. As it was the Tuber melanosporum season, I visited truffle markets in Lalbenque, Limogne-en-Quercy and Martel. These are the three most important contemporary and historic truffle markets in Lot. I conducted participant observation and informal interviews at these markets. I attended truffle festivals in both Lalbenque and Martel. I presented my preliminary results of my survey interviews at Lalbenque's 2015 
truffle festival. Pierre and I continued to conduct our semi-structured interviews. Finally, I attended a week-long introduction to trufficulture course taught by Pierre Sourzat at the Le lycée des territoires Cahors-Le Montat (The Territorial High School of Cahors-Le Montat). This course provided me with additional insights into how extension agents at Le Montat try to train and prepare trufficulteurs to practice "modern" trufficulture.

My third research period in Lot came in the summer of 2015 from June until August. Pierre and I continued our semi-structured interviews. I focused on my archival research in Lot's départemental archives. As well, I spent two days in the archives at the Sorges Truffle Museum, in search of more concrete figures of truffle production. In Lot, I read the archives contents on trufficulture, viticultural and phylloxera, documented truffle yields from agricultural statistic and began to examine population trends. As interviewees had expressed concern about rising truffle production in Teruel, Spain during survey interviews, I decided to visit Teruel, Spain. There, I met with syndicate officials, conducted semi-structured interviews with trufficulteurs in Teruel and visited truffle plantations.

During the 2015-2016 Fall and Spring semesters, while in Miami, Florida, I downloaded historic aerial images and georeferenced them to quantify land use and cover changes in important truffle-producing communes. These findings inspired me to return to archives to better understand reforestation in Lot. I will detail these remote-sensing methods in the forthcoming methods section of this chapter. I will report these results in Chapter 4 of this dissertation.

During the summer of 2016, from June until August, I continued my archival research in Lot's département archives. I focused on documents regarding demographic trends, agricultural policies, landscape change and the control of nuisance animals such as 
deer and wild boars. Pierre and I finished our semi-structured survey interviews, having interviewed 42 trufficulteurs. I attended summer truffle markets in Limoges-en-Quercy, and a truffle festival in Lalbenque.

I returned to Lot in January 2017 and remained until March 2018. I finished my archival research at the départemental archives in Lot. I conducted two weeks of archival research in Lot's départemental Patrimonial library as well, as they had early truffle manuals written by Lot's truffle scholars. There I read 19th century truffle manuals focusing on Lot and other documents regarding Lot's agricultural history. I attended winter truffle markets in Lalbenque and Limonge-en-Quercy. Having finished my field work during this period, I began writing an early draft of this dissertation during the same period.

The choice to conduct research over five different trips and a total of 14 months to Lot offered me a more comprehensive view of trufficulture there. Pivotally, these different research periods underscore how dependent truffle production was on meteorological phenomenon. During my second research period in December-January 2015-2016, trufficulteurs complained that they could not sell their truffles because of locally high production and competition from Spanish growers. The next two summers trufficulteurs talked less of Spanish growers but how long droughts and heat waves would all but destroy the year's truffle production. During the winter of 2016-2017 there were far fewer trufficulteurs selling truffles in Lalbenque than in 2015-2016. As production vacillated, concerns markedly shifted from market protectionism to how damaging anthropogenic climate change was for truffle yields. A single consecutive year would have unlikely captured such swings in truffle production and the differing analyses they provoked from trufficulteurs. These variations also spurred my thinking of expanding my analysis to 
include more humans and nonhumans that acted in truffle actor-networks. Such discrepancies underscored how easily presumed human control over truffles faltered.

\section{F. Research Methodology}

Here I describe the various research methods used to carry out my research. Soon after commencing this research, I realized that a mixed methods approach was necessary to understand changes in trufficulture over time. While participant observation and semistructured interviews provided valuable data about contemporary trufficulture, archival work and remote sensing allowed me to shed light upon trufficulture's history, a task only a handful of scholars have seriously attempted (Bye 2000; Castelnau 1978).

\section{i. Participant Observation}

From the outset of this research I conducted participant observation at meetings of truffle syndicates and associations, attended truffle markets and festivals and accompanied guides on staged truffle hunts. These hunts allowed me to witness how syndicate and associations leaders presented trufficulture to the public during these touristic truffle hunts. Listening to and speaking with leaders and trufficulteurs during meetings and truffle hunts rapidly helped form my research interests. I could witness how trufficulture was presented to the public on stage truffle hunts, something akin to a stable actor-network, and the complex technical and political debates that occurred in closed door meetings. In association and syndicate meetings, trufficulteurs debated seemingly foundational aspects of "modern" trufficulture such as irrigation, tilling the soil, fencing and the production of "mycorrhized" saplings. This actor-network appeared to be far from settled.

Yet these seemingly narrow technical debates soon became immersed in debates about government subsidies, tourism and truffle museums. Following ANT, I realized that 
in these meetings I needed to view these debates through "generalized symmetry" and not assume that political matters were necessary separated from scientific ones (Callon 1984). I soon realized from talking to trufficulteurs at these various events that there were considerable differences in how they practiced trufficulture. Their practices were often informed by radically different ecological if not ontological understandings of everything from truffles to syndicates to the climate to wild boars. Even if certain trufficulteurs' methods were consistently described as current best practices, these meetings showed how little uniformity there was in trufficulture in Lot.

Instead of recording these meetings in full for further transcription, I took detailed notes during the meetings. After the meetings I would reread my notes and note different subjects of interest in the margins such as markets, appellations and techniques. I would then refer to these themes later. While I do not report the results of my participant observation at truffle meetings and truffle hunts, this data was fundamental in crafting and analyzing the results of my semi-structured survey interviews.

\section{ii. Semi-Structured Survey Interviews}

To better understand the variety of methods of trufficulture being practiced in Lot, I conducted semi-structured interviews with trufficulteurs throughout Lot from July 2014-August 2016. Patten (2016) emphasizes that "semi-structured" personal interviews lend themselves to collecting large quantities of highly detailed "narrative material", the kind needed to explore the link between landscape change and truffle production through time. Furthermore, because of the general secrecy in the truffle world and perceived sensitivity around information (de La Pradelle 2006), I believe that personal interviews may decrease the tendency of informants to skip questions on mailed or online surveys, 
while this format also allowed me to ask clarifying questions when needed (Patten 2016). I divided the survey into three sections: 1) truffle ecology, 2) the truffle economy and 3) the past and future of trufficulture in Lot. I provide the survey questions in the appendix of this dissertation and the results of this survey in the second half of Chapter 5.

In the first section of the semi-structured survey on focus on truffle ecology, primarily on "inoculated" plants, fungal "contamination" and climate change. Truffle scholars have often examined on the effectiveness of "inoculated" plants. These plants, tree saplings, hope to ensure the symbiosis of host tree and truffle spores (Murat 2015). Yet, far from removing the mystery from the most fundamental relation in trufficulture (Pradel 1914), these plants have suffered from "contamination" from other fungal species and a lack of "colonization" of host species by Tuber melanosporum (Murat 2015). As I will report in detail in Chapter 5, trufficulteurs in Lot have had problems both with low levels of "colonization" as well as fairly high levels of "contamination", problems which have plagued many trufficulteurs (Sourzat 2009).

The second major focus of my questions on truffle ecology centered on anthropogenic climate change and its effects on trufficulture. Scholars have noted that climate change may already be affecting truffle yields if not species distributions (Büntgen et al. 2011; Splivallo et al. 2012). I wanted to understand if trufficulteurs acknowledged that climate change was happening and what had changed. Next, I asked them if climate change was affecting trufficulture, how it was doing so, and what if anything they were doing to counteract any negative effects. While contemporary truffles manuals universally recommend the installation of irrigation systems for "modern" trufficulteur, I found that many trufficulteurs in Lot did not believe the expenses of doing 
so were warranted even if they recognized irrigation would increase yields considering ever more frequent droughts in Lot.

In the second section, which I group as questions about the truffle economy, I asked trufficulteurs about differences in terroir and if Lot's truffles deserved a label such as an appellation d'origine contrôlée (AOC). These questions were informed by the fact that truffle syndicate and association leaders and their members were constantly discussing the possibility of gaining an AOC. In fact, Lalbenque's truffle syndicate had submitted paperwork to gain an AOC, but were denied because their production was too variable and unpredictable to furnish the potential number of buyers. This AOC for many was a way to differentiate their production from that of Spain.

Many in Lalbenque worried that Spanish production was undercutting their prices. The Spanish government had dramatically subsidized trufficulture, which had helped increase production (Samils et al. 2008). Based on these worries, I asked about the state of truffle subsidies in Lot and if they had personally applied for them and if they seemed to be sufficient or should be increased. While in meetings many argued fervently for greater subsidies, during survey interviews opinions were much more diverse.

I also included questions about the European Union's Common Agricultural Policy (CAP) and France's program to support farmer retirement to free up lands called l'indemnité viagère de départ IVD. When interviews began the truffle was not considerable to be a product of "culture", though by the end the tireless work of French, Italian and Spanish trufficulteurs had changed its status, allowing the possibility that the EU would subsidize trufficulteurs. 
While these first two sections dealt temporally with the present, in the third section, I wanted to gage how trufficulteurs understood the causes of declines in truffle yields over the $20^{\text {th }}$ century as well as how they felt about the future of trufficulture in Lot. As for the declines in truffle production in Lot, I included a list of 11 possible reasons for the declines include agricultural mechanization, climate change or declining agricultural and rural populations. I would allow interviewees first to respond and then provide this list of possible explanations if no response was forthcoming. Next, as the truffle syndicates and associations meetings that I attended helped me to formulate this survey, I included questions about the importance of these entities. Also, I wanted to understand how extension agents had assisted in the production of "modern" trufficulture in Lot. Lastly, we allowed trufficulteurs to opine on whatever issue we had not covered. We also asked them about the future of trufficulture in Lot, which elicited a wide range of responses from hopeless to optimistic.

I felt this survey was necessary because the meetings of trufficulteurs I attended included so many fascinating and nuanced discussions of trufficulture. Yet just as it seemed that these discussions were heading to center of the matter, they would inevitably veer off into long discussions discuss techniques such as the proper timing and dosages of irrigation. Therefore, I tried to amass what I found most interesting of these meetings and encapsulate it in a questionnaire to explore the diversity of opinions and practices that I had heard in discussions at truffle association/syndicate meetings.

Before implementing my survey questionnaire, I had my questionnaire reviewed by leaders in the Lalbenque truffle syndicate to ensure its comprehensibility and applicability as well as tested the survey on trufficulteurs (truffle growers) prior to data 
collection (Patten 2016). After making the needed post-test adjustments, I conducted 42 household interviews in total, which comprises roughly $15 \%$ of truffle syndicate and association members in Lot, France. At times, other members of the household participated, which means that I interviewed more people, but would record their responses on the same form. Often the interviewees partner would provide differing responses that in many cases increased the richness of this data.

I was less interested in the specific details of plantation management such as tree species or soil tilling techniques, we arranged to conduct interviews indoors and not in their truffières. Attempts to conduct mail-in and telephone surveys had largely failed. Therefore, I knew that I needed to visit trufficulteurs.

I targeted older trufficulteurs with familial histories of trufficulture. Based on his work as a truffle extension agent at Le Montat Pierre Sourzat helped me select such participants. We also tried to interview trufficulteurs throughout Lot to gain the greatest geographic scope. Therefore, my sample was selected purposively and is not random (Tongco 2007). Such purposive selection, as it is not random, prioritizes richness over generalizability to the entire population. Therefore, any statistical analysis is only applicable to the sample and not to the general population. Therefore, I only calculate basic statistics on the sample without generalizing results to all Lot's trufficulteurs.

Beyond the fact, that I focus on historical material, truffle scholars had warned me that there had always been reticence for trufficulteurs to share details of their truffières. Therefore, it is debatable how well a random sample would have worked, as many trufficulteurs would likely have chosen not to participate. Therefore, my purposive sampling is nonrandom, but provided me with rich family histories spanning decades of 
trufficulture. These sampling strategies introduced me to an amazing group of thoughtful people with a true breadth of knowledge on trufficulture in Lot.

I conducted these surveys from July 2014 to July 2016. This long period of conducting interviews proved helpful as I surveyed people during both favorable and unfavorable years for truffle production. Changes in truffle production seemed to have only increased the diversity of opinion which I captured in my surveys. As I had broken down the survey into the ecology, economy, and decline and relaunch of the truffle in Lot, I will continue such divisions in reporting my data. While I largely respect these organizational divisions in data reporting, I will demonstrate how actual actor-networks do not necessarily respect such divisions (Latour 2013).

\section{iii. Archival Research}

For my main source of archival data, I conducted archival research in the Archives Départemental du Lot in Dec-Jan 2014-2015, June-August 2015; June-August 2016 and Dec-March 2017. During the last period, I also conducted two weeks of archival research in the Bibliothèque Patrimoniale et de Recherche du Grand Cahors. This latter library had early truffle manuals that focused on Lot and a few other documents about agricultural history. My final source of archival data came from two days of research in the library at the Sorges Truffle Museum. For two days in Sorges, I searched for additional truffle manuals and other sources not found in Lot's archives and libraries. Therefore, I conducted the bulk of my archival research in the Archives Départemental du Lot in Cahors. I will discuss these archives in detail here.

I chose to focus my research in the Archives Départemental du Lot because of the sheer diversity of their archives. They had a comprehensive digital database through 
which I conducted a preliminarily overview of their holdings and then started my research. The helpful archival staff also guided me through their different non-digital databases which covered certain time periods from the Revolution to the 1940s. I first searched terms like truffles, trufficulture, trufficulteurs and such related terms in the digital database. I first read these all these archives to gain a perspective on what if any work had already been done on the history of trufficulture in Lot. Castelnau (1978), the most comprehensive work on truffle history save for this dissertation, was particularly instructive in providing other actants for further investigation.

My archival work was additionally a part of an iterative research process. I conducted semi-structured and participant observation at the same time as much of my archival research. My informants' insights into the history of trufficulture in Lot and France helped guide my archival research to focus on agricultural change in Lot, the phylloxera epidemic, the rural exodus and landscape change. It became clear from these interactions that the phylloxera epidemic and the agricultural change were "obligatory passage points" (Callon 1984:202) to understand truffle history in Lot.

I listened to these informants and followed their leads in my archival work (Latour 1996). With a list of actants to explore, I sought to "describe" these actornetworks instead of trying to explain them. Description, per Latour (2005) construct actor-networks instead of seeking context or other actants "outside" of them. As well, Latour (2005) clearly acknowledges the debt ANT owes to ethnomethodology, in trying to pay genuine attention to the world-building activities of research subjects and not to impose some greater structure or other causes that trump their descriptions. These interviews with current trufficulteurs, especially the questions regarding the decline of the 
truffle, helped steer my archival work as I wished to quantify and more richly describe the leads gained from my survey interviews.

Yet before investigating these other actants provided by my informants, I knew I needed to describe truffle yields more clearly than any scholar had previously done. I wished to learn exactly how "golden" the truffle "golden age" was (Chazoule 2004). I found that the government included a space for truffle data from the early 1900s to the early 1940s. While others had questioned the veracity of this data (Chatin 1892), I found no other viable data sources. While Chatin (1892) could have consulted truffle merchants about yields from that time, today no one remains alive from that time. To the best of my knowledge these archives are all that remains, and the only long-term archives available to me were those in Lot's départemental archives.

In the non-digital archives, I found additional documents that further cataloged the number of hectares under cultivation, which allowed me to understand trufficulture at the plot level. This plot level data allowed me to provide estimates for per hectare yields, which I argue are new and useful baselines with which to judge current attempts to "relaunch" trufficulture in Lot. Per hectare averages indicate that truffières were far more productive in the early 1900 s than they are today. Such data guided me to try to find the source of such discrepancies.

I was not only interested in the truffle yields from the early 1900s. I realized that I needed to recreate the entire period in as rich of detail as possible to understand the actornetworks producing such high truffle production. Describing the "golden age" of the truffle (Chazoule 2004) sent me on a wide-ranging quest through the Départemental Archives of Lot in Cahors, France. Explaining its decline led to tracing (Latour 2005) a 
far more diverse and surprising network than what I had initially envisioned. In each case I followed the humans and nonhumans who seemed to drive truffle production. Yet in following the principle of "generalized symmetry" (Callon 1984; Latour 1993) I followed the same methods I did to describe the truffle's rise as I do for its fall. There is nothing intrinsic in an actor-network's success or failure, but instead the maintenance or undoing of its relations decide its fate (Latour 1983).

To better understand the broader milieu in Lot, I read archives on viticulture and particularly on the phylloxera epidemic. Next, I searched for and read archives relating to sheep raising, cereal farming and other important cash crops like tobacco. I noted numbers of sheep raised and hectares of different surfaces under cultivation. Having understood Lot's decline in agricultural, I looked at demographic data from the mid1800s on to understand emigration from the department. Lastly, I read all documents pertaining to afforestation and reforestation in Lot as well as those pertaining to attempts to limit forest growth and restore agriculture on the causses. Archives related to these subjects were incredible rich up until the 1970s, when material became sparse. This lack of document availability meant that I would have to understand further changes in agriculture and trufficulture in Lot based on my semi-structured survey interviews.

As future chapters will show, I was particularly interested in quantifying these foci from truffle yields, to hectares cultivated in wheat to human populations. I knew that these data would show the agricultural revolution that occurred in Lot. For truffles, such data is frustratingly undependable. While good data were available for the period of 1900-1938, thereafter finding data on truffles all but an accident. It seems that the French government at all levels ceased to be interested in truffle data. Frustratingly, communal 
data even during times of high production became ever sparser and more unreliable, which likely led to me underestimating truffle yields. Yields by that point had already begun their decades long decline. Whatever their reasons, this lack of data was frustrating as I had to again rely on others' estimates of truffle yields. The actor-networks that produced truffle data themselves were breaking down as well.

Beyond these critiques of data collection in Lot, one must analyze the archives themselves. For ANT, a text like an archival document is as well an actor-network. A map or report is the result of the assembling of many humans and nonhumans (Latour 2013). In my archival research, I did not seek means to transcend actor-networks to somehow locate a "realist" singular and external truth that could define this time through archival research (Durepos and Mills 2012). Instead, I examine the "internal referents" and the "world building" in these texts (Latour 1983; Latour 1988). Following ANT's methods on textual analysis, I do not try to find some objective truth outside these documents, but stay local and describe the complexity contained within (Law 2004).

At the same time, I assumed no intentionality or motives of actants whether, human or nonhuman. This a kind of "radical indeterminacy" (Callon 1999) attempts to limit any prejudices against who can or cannot be an actor and about which actions they are capable. I tried to admit new human and nonhumans actants as late as I could in my archival research. Therefore, I began with now define list of actants or their capacities. Instead, I followed clues and let the actants emerge from the archives. As with the truffle, many trails I followed merely ended when there was no more quality data, no lasting material traces left to follow. Therefore, while I feel my work has dramatically advanced 
the historiography of the truffle, new documents and data sources could greatly enrich these actor-networks.

Description, per Latour (2005) construct actor-networks instead of seeking context or other actants "outside" of them. Therefore, one must "look down" to understand outcomes (Law 2004). As well, Latour (2005) clearly acknowledges the debt ANT owes to ethnomethodology, in trying to pay genuine attention to the world-building activities of research subjects and not to impose some greater structure or other causes that trump their descriptions. These interviews with current trufficulteurs, especially the questions regarding the decline of the truffle, helped steer my archival work.

In ANT, description is paramount, while preemptively seeking explanations further short-circuits the actual description and "assembling" of these actor-networks (Latour 1996). Explanation, if anything, is an effect or result of these actions of “assembling” networks. Therefore, I spent over eight months conducting archival research, to ensure that I had rich descriptions and that I had not left important actants out of my account (Latour 2004).

I paid attention to how actor-networks reformat common conceptions of scale and temporality (Latour 1996a). Through these archival documents, I try to follow both trufficulteurs and the truffle as they circulated through time and beyond Lot's boundaries. Furthermore, instead of sticking to the periodizations of the "golden age" or "belle époque" of the truffle (Chazoule 2004; Rebière 1974), I treat time more fluidly and temporal proximity as an effect of associations and not something that automatically severs associations (Latour 1993; Latour 1996a). Temporal and spatial fluidity strengthened my archival work as it did not unnecessarily constrain actants effects inside 
of preordained spatial or temporal boundaries. The archives helped me travel to the mid1880s, even before truffle production statistics were available.

I did not only seek out archives only relating to human activities. From a wide variety of reports from the foresters who advocated reforestation projects, to government surveys concerned about the negative impacts of silvopastoralism on trufficulture to documents about hunting subsidies, I could locate active nonhumans in these archives. While they were rarely the sole subject of archives, my extended attention to nonhuman agency and dedication to finding it combined with a helpful archival staff meant that I could find considerable traces of nonhuman agency in these archives as well. Without ANT as my guide, I may have not searched for them so diligently and creatively.

\section{iv. Remote Sensing}

Another useful way to view nonhuman actants in trufficulture's past in Lot was through the classification of remotely sensed images. I relied on these images particularly relied on these archives as post 1960s the richness of the archival data waned. The use of remotely sensed images is a quick and comparatively inexpensive way of studying land cover changes over time (Mas 1999). Different data sources differ in the spatial resolution (pixel size), spectral resolution (detectable wavelength intervals) and temporal resolution (the frequency with which images are recorded), which allow or constraint different kinds of analysis. Data storage capacities, project budgets and research questions will determine the various resolutions needed as well as the choice of available images (Jensen 2009). Remote sensing has become widespread across many 'hard' scientific disciplines (Goetz et al. 1985; Jansen 2009; Turner et al. 2003). 
Social scientists have as well adopted remote sensing as a methodology (Rindfuss and Stern 1998), though not without critics of its application by those who claim to use images as supposedly objective data that can often obscure human conflicts over use of nature (Chapin et al. 2005). Furthermore, one can see that change has occurred in land covers through remote sensing, but one may not be able to determine from these images why such land use changes occurred and who or what produced them without additional 'on the ground' data (Rindfuss and Stern 1998).

Fairhead and Leach (1996) demonstrate how to successfully combine ethnographic data with remote sensing. Through remote sensing, they show that forest cover was increasing in their study area. Yet it was only because of their intensive on the ground ethnographic fieldwork that they could show that local people had planted these forests. Their remotely sensed images demonstrated land cover changes, while additional ethnographic data could explain land use changes, which corrected the erroneous assumption that local people had deforested the area.

When conducting a remote sensing analysis of land cover change over time, one must always remember this difference between land cover and land use. Conflating the two can produce incorrect analysis about the causes of observed changes (Jansen and Cowen 1999). Therefore, while remote sensing is a powerful tool, one should not overstate its findings (Jensen 2009), especially when dealing with "cultural" landscapes that have had long-term human inhabitation (Groom et al. 2006) and high levels of "hybridity" (Robbins 2001). Such landscapes are exactly the kind in which trufficulture was long practiced (Bosredon 1887). Keeping such mixed-method approaches in mind, in 
this paper I provide additional analysis of my land cover classifications based on the archival data I collected at the départemental archives in Lot, France.

To document land cover changes in Lot, France, I acquired aerial images from France's National Institute of Geography (Institut National de L'information Geographique et Forestiere) (IGN). Their Geoportail website provided free .jpg images for the Carte de Cassini (completed at the end of the 18th century), L'Etat Major (completed in the early to mid-1800s) and then high spatial resolution largely black and white aerial imagery from 1948-2000 for Lot that were usually taken roughly every 10 years, though times varied (IGN 2016). Archival data suggested that few marked changes occurred in a decade, while the actual work of classifying these images was too great to do with greater frequency than 25 years or so. At the department level, I acquired LANDSAT images from 1975 and 2015 to study large-scale trends in forest cover changes in Lot. I did not use these LANDSAT images for any change detection analysis against the IGN data. It analyzed them separately, as the LANDSAT images were used primarily to confirm trends found in the archives.

Based on archival data, I selected the communes of Martel, Limogne and Lalbenque to represent the kind of land cover changes that impacted truffle production. These communes were all important truffle producers and all were market centers in the early 20th century (Castelnau 1978; Champagnac 2000; Mayssonnier 2010). To create a broader sample of communes in Lot, I downloaded images for communities who had generally been more marginal truffle producers but still regular producers like Gourdon and St. Gery. These additional communes allowed me to superficially compare land cover changes in major-truffle producing communes to those who were not, though it is difficult to determine 
the exact role that trufficulture played given the complexity of the processes driving reforestation in Lot.

After downloading images with a temporal resolution of roughly 25-year intervals for the above communes, I georeferenced the raw .jpg files, which depending on the size of the commune and resolution of the images was between four and fifteen images. Next, I clipped the images to fit within the commune boundaries, then mosaiced these rasters to create continuous images for each commune.

Also, based on archival data and a cursory examination of the spatial resolution of available images, I digitized these images into the following land cover classifications: 1) Forests, 2) Truffières, 3) Fields, 4) Built Environment and 5) Water. While the spatial resolution was between one to two meters for the images, the fact that most images were in black and white greatly limited their spectral classification. Therefore, I did not try to attempt to classify the category of agricultural fields into specific crops. Additionally, I classified areas with regularly spaced trees with interrow clearings as truffières, even though fruit and walnut tree plantations can complicate such classifications. Once these images were classified, I calculated the surface area individually for the above classifications to provide data based on the different land covers.

Because of the coarseness of the data available in the Cartes de Cassini and L'Etat Major maps, I was only able to classify the digitized images into the following land covers: 1) Forests, 2) Fields and 3) Built Environment, though the Cartes de Cassini had limited data on built environments. As these maps only illustrated larger forested areas, the calculations are likely skewed towards more agricultural areas than might have existed as smaller forest patches are not drawn. 
As for the LANDSAT images, I resized the 1975 image so that it had the same 30m spatial resolution of the 2015 imagine. Next, I conducted a supervised classification by selecting 50 forested pixels and 50 non-forested pixels to utilize the maximum likelihood classifications. Irregular spectral variances visible to the naked eye made even such a simplified classification complicated. While the data corroborates trends from my archival data that suggests large-scale reforestation in Lot (Chambre de Commerce 1994), these results should be treated with caution. Only LANDSAT images allowed me to examine Lot. The historical black and white aerial images had too high of a spatial resolution to work on the scale of the département of Lot, given my time and labor constraints. Yet this spatial resolution of LANDSAT images did not allow me to dependably classify truffières. Therefore, I looked at forested and non-forested land.

This mixed methods approach allowed me to study past and present iterations of trufficulture as well as to describe the effects created by both human and nonhuman actants. Data about land cover were increasingly lacking from the 1940s-1970s, so classifying these images filled these gaps. Next, careful survey participant selection provided me with data from the 1970s onward. No one data source sufficed, but when combined these various data sources were rich enough to form a contiguous picture of trufficulture over a century and a half.

\section{G. Dissertation Organization}

This dissertation is divided into six chapters. In this first chapter I have introduced this dissertation, stated its general research objectives, discussed my selection of the truffle as a research subject and Lot, France as the ideal place to study it, introduced 
essential aspects of truffle ecology and provided detailed descriptions of my mixed method approach. Now I will provide an overview for the entire dissertation.

While in Chapter 1 I describe briefly how I would use ANT to engage with trufficulture, in Chapter 2 I focus on how ANT acted as a driving theoretical and methodological force in my research on the history of French trufficulture. I elucidate how ANT functioned both as a theory and overarching methodology for my research. I will respond to common critiques of ANT and how this study will avoid some of its most commonly cited pitfalls. As well, I describe how ANT's methodological possibilities aid me in this chapter to reflexively examine my own status as an actant in the truffle's actornetwork and my intentions to intervene in these actor-networks.

After having detailed how ANT drives my theoretical and methodological orientations in Chapter 2, in the next three chapters I present my research findings. I continue to analyze my data wholly through an ANT lens. I have chosen to divide the description of my results into three chapters to highlight the unexpected twists and turns in the history of French trufficulture. This breakdown as well serves a clear chronological function. While I separate these time periods for organizational purposes, I will also explore the ways in which they are interconnected

In Chapter 3 I describe the complex conditions under which trufficulture flourished in the French département of Lot. In the first part of the chapter I focus on how the phylloxera epidemic helped prepare landscapes for trufficulture. In the second half of the chapter I describe how truffle production flourished in Lot. By the late-1880s Lot was the third highest truffle-producing French département. I describe the actor-networks that made what some have called the "golden age" of the truffle through a close analysis of 
archival documents in Lot's départemental archives. Following ANT "sensibilities" (Law and Singleton 2013), I have read these archives attentive to the ways in which humans, nonhumans and their hybrid relations made such high truffle yields possible.

While the archives analyzed in Chapter 3 describe the assembling of the "golden age of the truffle" (Chazoule 2004), in Chapter 4 I examine the same archival library to understand why this golden age was short-lived. I focus specifically on the third main truffle-producing département of Lot, France to understand changes in actor-networks that become unfavorable for truffle production. I combine archival research with the classification of remotely-sensed images to describe how landscape changes unfavorable to the truffle's ecology dominate in Lot. I focus on these pivotal decades to understand declines. My archival work provides the most comprehensive and detailed records of truffle production ever assembled. My remote-sensing work provides the clearest illustration and quantification of how landscapes changed in a major truffle-producing area during the period of the truffle's great decline.

The data I present in Chapter 4 are not encouraging for the future of truffle production. They suggest that the truffle could even disappear from places like Lot, France. In Chapter 5, I detail how by the 1970s scientific research on the truffle recommenced. I describe new findings in truffle science and their applications to trufficulture. I detail the number of problems which have plagued trufficulture despite these scientific advancements. Next, I describe how a group of trufficulteurs (trufflegrowers) in Lot, France have tried to relaunch truffle production under "modern" methods. Since the 1970s a continued interest has sought for a second truffle "golden age". My interviews with 42 trufficulteurs in Lot, France demonstrate that there is just as 
much variation as homogenization of trufficulture techniques. I investigated their ecological understandings of trufficulture, their opinions of the economic role that trufficulture plays in Lot, their reasons for the decline of truffle production detailed in Chapter 4 and finally their prognosis regarding the future of trufficulture. In addition to household, semi-structured survey interviews I analyze in this chapter, I also utilize 14 months of participant observation at truffle syndicate meetings, public truffle hunts, truffle festivals and visits to truffle farms to enrich my understandings of my survey data.

Having described my researching findings in Chapters 3, 4, 5, in Chapter 6 I discuss these chapters together, while highlighting the contributions they make to ANT. I argue that few ANT case studies have sustained the kind of detail I have achieved over such a sustained timeline. Additionally, the richness of the data I have collected leaves little doubt regarding the status of the truffle as an actant.

Placing my researching findings in conversation with ANT will as well underscore how it was the best theory/methodology to help me navigate through the complicated history of the truffle. I conclude this chapter and this dissertation by offering recommendations for the future of French trufficulture. I argue that the long-term historical view I have described in this dissertation allows me to propose alternatives to common dominant conceptions of "modern" trufficulture (Callot 1999) that exclusively focus on technological innovation. My ANT orientation allows me to reconceive of these actor-networks in different manners. I argue that many more actants, especially nonhumans, should be considered when reimagining the future of French trufficulture. 
Chapter 2: Examining ANT's Theoretical and Methodological Strengths

\section{A. Overview}

In this chapter I will explain how ANT guides my theoretical and methodological approaches, highlighting those influences that are most critical to this dissertation. I will first focus on ANT's theoretical contributions. I provide a general introduction to ANT, list some of its principal critiques, describe its fundamental "sensibilities" in detail (Law and Singleton 2013:488) and discuss "generalized symmetry" (Callon 1984:200). I then introduce the fundamental characteristics of ANT methodology and describe its application in practice. I close by describing my transformation of ANT theory into methodology for my study of trufficulture.

\section{B. Introducing ANT}

I do not pretend that working with ANT is straightforward. Any theoretical examination of ANT is complicated. Its principal scholars question if it even is a theory in the sense of a fixed set of frameworks that can be 'applied' to analyze a broad set of phenomena (Latour 1996a; 1999; Law and Singleton 2013; Mol 2010). ANT scholars consistently change it and add to its "repertoire" instead of trying to solidify or confirm past findings and methods (Mol 2010). It is through case studies that scholars enact, shape and modify ANT (Law 2009). With such change and reinvention, it is entirely possible to say that there is not one ANT, but instead various and not mutually exclusive ANTs (Clarke 2002). To further complicate matters, its principle scholars have even critiqued every aspect of the term actor-network theory (Latour 1996a; Latour 1999). Furthermore, it has been under almost constant revision for over three decades (Callon and Latour 1981; Latour 1987; 1993; 2005; 2013). 
Theory or not, ANT is not without its influences. Some argue that it is a less grand version of Foucault's (1984) concepts of discourse or episteme and is heavily influenced by post-structuralism (Law 2009). Others have noted the impacts that ethnomethodology has had on ANT in its notion of "learning from the actors" (Clarke 2002; Latour 1999; 2005). Still others note a strong resemblance to and a more empirical version of Deleuze's assemblage thinking and rhizomes (Müller 2015). Acknowledging the latter influence, Latour (1999:19) even admits that a better name for ANT could be "actant-rhizome ontology", again showing that it is not a theory in the traditional sense.

Yet if ANT itself is as "fluid" and "multiple" as the actor-networks its describes (de Laet and Mol 2000; Law 2009; Mol 2010), one could feel affinity with Latour's (2005) satirical dialogue between himself and a frustrated prospective student who wonders how ANT will allow them to finish their thesis. A similar tension is shared between student and teacher in Aramis over research methodology and scope (Latour 1996). 'Applying' ANT is no straightforward task. With such admissions of its complications even from its most renowned practitioner, it may seem more reasonable to follow another theoretical path other than ANT. ANT even frequently questions fundamental concepts in the social sciences like the existence of structures separate from actors, the a priori fixed definition and division of nature and society, the separation of reality and our perceptions of it, predictable differences in the "global" and "local", and the secure roles of humans as subjects and nonhumans as objects (Callon 1984; Latour 1993; 2004; 2005; Law 2004; 2009). Instead of taking categories like nature and society for granted, each case study redefines them (Latour 1993; Law 2009). ANT's focus on careful and detailed "description" and "following the players" of the way actants effect 
one another (Latour 1996) leads to a kind of methodical, "slowciology" (Latour 2005:163) often best suited to lengthy monographs (Clarke 2002). With ANT, one also needs to learn an entirely new vocabulary complex enough that its scholars have had to publish guides and indexes to explain it (Akrich and Latour 1992; Latour 1999a).

\section{Common Critiques of ANT}

Many social scientists question ANT's politics and its radical credentials (Fine 2005; Lee and Brown 1994; Rudy 2005; Whittle and Spicer 2009). While relying so heavily on ANT might not be the safest choice, I argue that the powers that ANT grants to the researcher are 'radically' greater than any potential pitfalls. Its preconception with the "construction" of not only society and nature or "social-natures" (Latour 1993; 1996a) allows the researcher to envision a different "progressive composition of the common world" (Latour 2004:18). I agree with Latour (2004) that the "composition" is unquestionably a form of politics. I find the humanist calls for the return of inert nonhumans, without the kind of "vibrant materiality" (Bennett 2009) that affects and is affected by humans to be itself horribly reactionary. The multiple ecological crises from a cavalcade of species extinctions, often referred to as the Anthropocene, to the unpredictable feedbacks from anthropogenic climate change seem like an odd time to now claim ultimate human control over the biosphere (Latour 1993; 2010; 2014). If anything, we as humans need to completely rethink our relations with other humans and with nonhumans as well (Latour 2010; Tsing 2015). Social science's obsession with anthropocentric critique may have indeed "run out of steam" (Latour 2004a) if one only attacks assumed "matters of fact" about nature and society (Latour 2004:27). Instead of stopping at critique, ANT attempts to include the "missing masses" 
(Latour 1992) into new "matters of concern" that entirely reimagine and reconfigure social and nature actor-networks (Latour 2004a). From increasingly frequent crises of capitalism to more unpredictable "novel ecosystems" (Hobbs et al. 2014; Tsing 2015), there seems to be little need to retain faith in modernist conceptions that vacillate between a transcendent nature or society that solidly exists outside of relations (Latour 1993). Any hope that nature will conform to ideas of balance and equilibriums that will revert to solid states after disturbances is outmoded and farcical (Botkin 1991; Scoones 1999). Thus, I argue that we need to embrace the fragility, mutability and "hybridity" of actor-networks without "purifying" entities into society or nature. We need to become "nonmodern" and recognize and seek to understand the new nature-society "imbroglios" that are becoming ever more prevalent (Latour 1993).

Despite my selection of ANT as the ideal theory/methodology to guide my research on the shape-shifting actor-networks of truffle production and truffle science over the last 150 years in France, I will still respond to vociferous critics of ANT. Frankly, I believe their critiques are often of dubious value as they conflate, cherry pick and outright misconstrue ANT in their will to critique. Still, responding to these critiques will further elucidate my thinking on ANT, and clarify how it is the best toolbox with which to describe (Latour 2005) the rise, fall and attempted "relaunch" (Champagnac 2000) of truffle actor-networks in France over the last 150 years.

Through my own case study of the rise, fall and attempted relaunch of truffle production in France, I describe a case with a novel kind of "generalized symmetry" in treating successes and failures with the same tools and vocabulary (Callon 1984; Clarke 2002). I also follow ANT's idea of "generalized symmetry" in reporting how scientists 
talk about politics and when politicians discuss science. Further I attempt to use the same terminology when discussing human or nonhumans and make no a priori judgement of what actants belong to nature or society as it may influence one's view of what entities have agency and which do not (Callon 1984).

Instead of dealing with success or failure alone (Clarke 2002), my case study deals with both. Latour (1996) and Callon (1984) describe how actant-networks fray, while Latour (1983) deals with stabilized actor-networks. Over time, this study deals with both stability and instability. My case study demonstrates that ANT can deal equally well with stable and unstable actor-networks (Callon 1984). ANT's careful linguistic use and vast vocabulary help grant it these capacities (Callon 1984; Latour 2005).

Being complicated enough that scholars have created dictionaries of its terms (Akrich and Latour 1992). Even if I do not try to add any clever coinages to ANT's already labyrinthian "infra-language” (Lee and Brown 1994). Instead, I believe the ambition and scope of this study makes it a major contribution to ANT in its examination of how a single actor-network can become relatively stability, become instable and just how complicated attempts to restabilize it can be. Such changes an actor-network come from ever shifting associations between humans and nonhumans, changes I chart in this dissertation. I will discuss these contributions further in Chapter 6.

\section{Describing ANT’s Fundamental "Sensibilities”}

ANT seeks far more to describe how than to explain why a phenomenon exists (Law 2009). Instead of a ready-made theory that researchers can apply, ANT is a series of shared "sensibilities" that offer no fixed course of action, or preconceptions of what entities 'count' (Law and Singleton 2013). While these "sensibilities" are best 
demonstrated in case studies (Law and Singleton 2013; Mol 2010), I will describe and comment on several "sensibilities" at length here as well as the critiques leveled at them. Penultimately, I will explain how ANT's “sensibilities", its most common foci and concerns can help illuminate my case of trufficulture. Finally, I will explore "generalized symmetry" and how it strengthens my analysis.

\section{i. Relational Effects}

One consistent "sensibility" for ANT is to view the world "relationality" much in the way semiotics understands how the meanings of words change with their relation to other words in a text (Law 2009; Law and Singleton 2013). While such relational, semiotic approaches are often applied to texts (Latour 1988), ANT applies this semiotic analysis to non-textual phenomenon as well (Law 2009) from the "multiple" ways of diagnosing disease (Mol 1999), to mass transit systems (Latour 1996) to organizational studies (Whittle and Spicer 2009) to literacy studies (Clarke 2002). Using a linguistic metaphor, ANT often describes associations between actants as "translations", whereby

just as in textual translation, meanings change and each actant is affected and transformed through relations (Callon 1984). Humans and nonhumans are both relational effects of their actor-networks (Law 2009). These are not solid, preexisting 'networks' like railroads. They are not social networks but instead, associations of humans and nonhumans that co-constitute actants and networks (Latour 1996a; 2005).

\section{ii. Human and Nonhuman Actants}

For ANT, actants are not only those who act and create effects, but also those that are affected (Latour 1992). These relations and their effects "provide actants with their actions, with their subjectivity, with their intentionality, with their morality. When you 
hook up with this circulating entity, then you are partially provided with consciousness, subjectivity, actoriality, etc." (Latour 1999:18). It is through different "trials" that an actant comes into being. The more actants with which they relate the more active they become (Latour 1990a) and the stronger they become (Callon and Latour 1981). If all is well, such relations in turn help to maintain actor-networks (Latour 1984). It is hard to replace any actant that breaks down. Such "betrayals" (Callon 1984) have unpredictable and difficult to substitute effects on the other actants (Johnson 1988). Still, replacement occurs. Humans often delegate substantial work to nonhumans, which in return, constrain and alter human behavior (Latour 1992; Winner 1980). Government officials try to convince people to drive the speed limit, but a speed bump and the impacts it has on their cars can be more effective in changing behavior (Latour 1992).

One of the most controversial aspects of ANT for humanistic scholars is its inclusion of both humans and nonhumans as actants (Callon and Latour 1992; Latour 1992; Law 2009; Walsham 1997; Whittle and Spicer 2009). Again, for ANT, nonhumans are not mere objects as their removal greatly impacts humans and other nonhumans (Johnson 1988). Their undependability can help ensure project success (Latour 1983). They can also "betray" and "push back" on human attempts to control them (Callon 1984; Latour 1992; Robbins 2001).

Additionally, nonhumans interest humans and fascinate them (Bennett 2009). They have the "power to" make humans act on their behalf and vice versa (Law and Singleton 2013). Yet contrarily to Whittle and Spicer's (2009:4) claims that ANT posits that "a machine can therefore be thought of as having, in principle, the same degree of agency as a person", these is no assumption that humans and nonhumans are the same 
(Latour 2005). Instead actants change through relations, associations or "translations" and produce effects on other actants (Callon 1984). Often projects need to reconceptualize both human and nonhuman relations to succeed, instead of maintaining actor-networks as they are (Latour 1992). There is no a priori assigning of "competencies" in ANT, but instead ANT adheres to a kind of "radical indeterminacy", which argues that only through interactions do actants fill out their ontological status and networks will form, stabilize or fall apart (Callon 1999; Latour 1996).

Actants do not have to demonstrate clear intentionality. As in the case of scallops, ANT in no way denies intentionality or human actants' attempts to define themselves (Callon 1984; Latour 2005). It does not define uniform human competencies or agential properties that are applicable to all situations (Latour 1996a). Ironically, critics of ANT's denial to tie agency with human intentionality fail to mention staunch humanists like Giddens (1984) and his concept of “structuration” or Bourdieu's (1984) concept of "habitus", each which clearly recognize that not all human agency is intentional, even if these concepts do not explicitly or implicitly grant agency to nonhumans.

Yet some scholars are aghast by this granting of agency to nonhumans. They liken it to a mere extension of "liberal democracy" to nonhumans (Lee and Brown 1994). These critics feel emboldened enough to retain the ultimate godlike status and understand nonhuman subjectivities and to 'know' that nonhumans have no intentionality or thought at all (Shaviro 2015). They also assume without any supporting data that humans act complexly while nonhumans act only by instinct (Masssumi 2015). Here a horrible, transcendent, but undescribed nature is an object and mobilized to show just how inert nonhumans are and presumably how powerful humans are in comparison (Bennett 2009). 
Unfathomably, for some, it is more radical not to extend "liberal democracy" to nonhumans (Lee and Brown 1994; Whittle and Spicer 2009). In such arguments, struggles over human rights supposedly depend on the denial of agency to nonhumans (Goldman et al. 2011). But can recognizing these actants really lead to the "death of man" as critics of ANT claimed (Latour 1999)? I am absolutely convinced the answer is no and that these humanist critics can in no way back up their claims. Nonhuman and "hybrid" agency only seems to be growing, and not waning (Latour 1993).

Again, in ANT there is no assumed difference between the effects produced by humans and nonhumans (Callon 1984). For ANT, all actants, human or nonhuman, arrive without fixed ontologies prior to associating with other actants (Clarke 2002). The fact that humans and nonhumans are the product of these relations, means they are hybrids. These hybrids "proliferate" between what the moderns "purified" into nature and society. One cannot say if any actant or "quasi-object" is wholly natural or social but instead a hybrid (Latour 1993). In addition to "hybridity", the same actants may demonstrate not only "fluidity" as they are transformed in different actor-networks. A piece of the same technology can function in one actor-network and not in other (de Laet and Mol 2000). In addition to fluidity, Mol (1999) argues that different actor-networks can produce "multiple ontologies" for the same actant and not different perspectives for the same actant. The case of the markedly different means of diagnosing anemia in a clinic versus in a laboratory demonstrates "multiplicity". Varying relationality in different actor-networks produce such multiplicity. Whittle and Spicer (2009:7) claim that ANT refuses to note "the multiplicity of meanings and uses around (seemingly) 'the same' artefact", completely ignores studies by de Laet and Mol (2000) on an actant's fluidity 
and Mol's (1999) and Law's (2004) concept of multiplicity. To make such a critique one must argue that there are merely different perspectives of the same actant, the exact meaning Mol (1999) carefully avoided.

\section{iii. Actor-Networks}

Actor-networks are the "complete chain along which competences and actions are distributed", which includes both human and nonhuman actants (Latour 1992:243). Law (2009:151) emphasizes that ANT does not posit that networks have any "stable prime mover, social or individual, to construct anything, no builder, no puppeteer." Above all, a human "system-builder" does not control networks (Law 1987). There is no "outside" causality of an actor-network if one has described it correctly. Action and agency rests fully within a properly described actor-network (Latour 1990a; Law 1992).

ANT does not take "human-centeredness" for granted in actor-networks (Murdoch 1996). Actor-networks are the products of "heterogenous" or hybrid associations, that are created and maintained between humans and nonhumans (Law 1992; Latour 1993). "Door closers" can transform offices (Johnson 1988) just as a manufactured air pump helped Boyle prove laws of nature (Latour 1993). The functioning of an office or Boyle's reputation would not be the same without nonhumans. Yet this aspect of ANT, that actor-networks contain both nonhumans and humans, and that human actants rely on nonhumans and vice versa (Latour 1983; 1993) is often misunderstood.

One critique lobbed at ANT claims that by even mentioning "society" and "nature", no matter the air quotes or how non-dualistically it claims to treat them as "hybrids" or "quasi-objects" (Latour 1993), ANT still falls prey to an unfortunate 
nature/society dualism (Sundberg 2014; Whittle and Spicer 2009). Latour (1993) is very clear in his usage of these terms as a "modern" artifact. He clearly argues that the "Great Divide" between what is commonly referred to as nature and culture cuts along the other supposed divide of the West who believed in such divisions and the many who did not. With ANT, one should always assume that nature and culture are hybrids of humans and nonhumans (Latour 1993). Furthermore, there is no nature or society, if one wishes to use those terms, until one has fully described actor-networks. The use of those terms comes at the end and not at the beginning as for other theories. Therefore, these concepts carry no explanatory weight in ANT accounts (Latour 1993; 2005).

ANT's critics frequently claim that because it fails to replay the agency-structure debate with its coinage of actor-networks (Latour 1999) that ANT is all too often unconcerned about inequalities based on race, gender, sexuality, class, among others (Whittle and Spicer 2009). Similarly, Star (1990) argues that many actants are left out of actor-networks, the kinds of human actors left out of white, male oriented accounts. Tsing (2015) criticizes Callon (1984) for only briefly mentioning Japanese scallop science before focusing exclusively on French "translations" of their science. ANT, in these critiques, not only fails to be politically 'radical' but downright conservative (Whittle and Spicer 2009).

Müller (2015) argues that actants only become "political" through associations as they transform one another and thus transform actor-networks. The development of "hybrid" tomatoes and low-lying bridges are political in that they change human and nonhuman behaviors and favor some groups over others (Winner 1980). Boyle practiced politics of a kind by showing that his "air pump" could produce and record the vacuum; it 
could act as a spokesperson more accurately than any human could (Latour 1993).

Pasteur gained considerable by 'extending' the results of curing anthrax in his laboratory to farms across France (Latour 1983). Here ideas of politics are greatly expanded through ANT (Latour 2004).

Such actants become more powerful as associations increase, and more humans and nonhumans join actor-networks, instead of power existing a priori and being held in different structures (Latour 1984). Any structure able to constrain human behavior likely includes humans and nonhumans associating in actor-networks and cannot be taken for granted but must be described (Johnson 1988; Latour 1990). To paraphrase Latour's (1984) comments on society: "structures are not what hold us together [or hold us down]; they are what is held together".

iv. Materiality

A second major sensibility of ANT is its close attention to "materiality". Here the researcher does not appeal to some outside causes that they have not described in actornetworks to "explain" outcomes (Latour 1996). Some so-called "materialists" who are Marxist critics claim ANT is incapable of deeply analyzing capitalism and its firm, enduring structures (Fine 2005; Rudy 2005). Others recognize that it can help understand the hybridity and materiality of commodity chains (Castree 2002).

ANT recognizes that what is often thought of as "materialist" analysis pays little attention to actual materiality. Instead such work can posit causality on massive forces like global capitalism, so other sciences must "kneel before one specific science that of economics" (Latour 1990:21). Likewise, Bennett (2009) agrees that paying attention to 
the "vibrant materiality" and agency of nonhumans can be far more attentive to materiality than classic "materialist" approaches.

Unlike so-called "materialist" approaches, ANT does not consider an economy out there, but instead attends to the "performativity" of the discipline of economics that intervenes and shapes the economy (Callon 2006). Furthermore, nonhuman "inscription devices" help produce the data, the reports and files that provide the materiality for complex markets (Latour 1990). Markets not only exists in abstract forms but in concrete markets as well. In these markets, making calculation possible is itself an ongoing process and not a pre-existing condition (Callon and Muniesa 2005). Capitalism, like any other entity, must be constructed and described in actor-networks (Latour 1993).

One does not explain Portuguese navel dominance by large structures or concepts like imperialism but instead in the materiality of the ships, sails, navigation techniques, favorable winds, among other actants (Law 1987). This web of relations clearly includes both humans and nonhumans (Law 2009). Such lists of humans and nonhumans made many modernist projects possible (Latour 1990:21). Another example of the importance of materiality is that of the hotel room key to which a heavy weight has been attached. Whereas the hotelier may have asked their clients to return their room keys before leaving and posted signs requesting them to do so, the heaviness and awkwardness of the weighted key 'convinces' them to leave it at the desk. This simple device attaches clients to their keys and to the hotelier (Latour 1990a).

v. Stability and Instability in Actor-Networks

A third "sensibility" is that order and disorder are equally possible in actornetworks (Law 2009). Explaining stability or lack thereof is a major concern for ANT 
(Walsham 1997), with stability being rarer (Latour 1996a). Instead of relying on explanations of a fixed social order, actor-networks endure by increasing the number of human and nonhuman actants that they can "interest" through different means (Callon and Latour 1981; Latour 1990a). Nothing exists "outside" of networks to sustain them (Latour 1996a). Science is not built out of grand theories alone, but the careful work of taking many "inscriptions" from different devices to produce graphs and tables that lead to findings (Latour 1990). In stabilizing an actor-network, actants may become more powerful if they can guide the "problematization" of the project and make themselves indispensable enough to become "obligatory passage points" through which all actants must move. Still the difficult task of "interesting, enrolling and mobilizing" actants remains. Any actant can "betray” others (Callon 1984). Actor-networks need constant work to be maintained and stabilized (Latour 2005).

In exceptional cases, after knowledge is constructed and sustained in actornetworks it can become stabilized and "black boxed". People accept the result of these "black boxes" without opening them and contesting their contents each time the matter is raised (Latour 1987; Walsham 1997). Actants can also stabilized and become "immutable mobiles". They then can move between different places without changing their form or content. They can also move through time without changing as well. Thus, they can be combined in new ways. The printing press is an "immutable mobile" because it can perfectly reproduce a work, but then was also 'movable' to reproduce other works as well. These works clearly could as well circulate around the world without being changed (Latour 1990). 
Tsing (2015) has worked with the concept of "immutable mobiles" in her notion of "scalability". "Scalability" captures the ideas behind the colonial sugar plantation, which transformed both humans and nonhumans to furnish commodities for a global market. Likewise, sustainable yield forestry created monocultures that foresters hoped to manage with predictable per hectare estimates. In each case both humans and none humans 'rebelled' against these plans and neither could prove "scalable". They could not move from place to place without major modifications. These projects were in fact only "seemingly scalable" as they transformed humans and nonhumans through associations, instead of leaving such relations intact (Tsing 2015).

\section{vi. The Local Versus the Global}

A fourth important "sensibility" is that actor-networks transform both spatial and temporal scales (Latour 1996a; Law 2009). Therefore, one cannot assume that Euclidean distance or that the even march of time prevails in actor-networks (Latour 2005). The geographic distance of published maps has little resemblance with actual actor-networks. Networks are never bigger but longer and stitched together through associations (Latour 1996a). Both spatial and temporal distance depends greatly on relations (Walsham 1997). Growth is only possible if an actor-network can maintain long-lasting associations (Callon and Latour 1981). For ANT, all interactions are local, and the global if existent, is an effect of these multitudes of local interactions in actor-networks (Latour 1999). A global entity is "continuously local" (Latour 1996a). While many consider the global to be much more complicated, Law (2004a) advises that one should look down and note the greater complexity of local interactions. While some claim that this focus on the local weakens ANT (Whittle and Spicer 2009), Latour (1990a) argues that the macro- 
structure" of society consists of the same stuff as the "micro-structure". Likewise, ANT can "describe" projects which were meant to gain worldwide popularity but were utter failures, while other inventions that were conceptualized to be sold locally, but which had global reaches. Each project must start from the local and master "inscriptions" like files, tables, data and figures as well as other humans and nonhumans (Latour 1990).

Just as one cannot assume fixed spatial scales in actor-networks, one should not assume that connections are automatically stronger or weaker given their temporal proximity. Through their relations, actants may register far different time scales and even historical order. Therefore, like everything else in ANT, even the march of time is not taken for granted (Latour 1990a). Not all actants may have joined a project at the same time or share the same conceptions of what should be included in a timeline. Therefore, actants may not only share the length of a timeline but also what constitutes an event worthy of inclusion (Latour 1996). Assumptions of periodization and breaks in historiography obscure the historical continuity. By observing what actants and effects remain, there may be less of a break in history and more of a continuation in some relations (Latour 1990; 1993).

\section{vii. Power in Actor-Networks}

The final "sensibility", I will discuss is ANT's unique analysis of power. For ANT, both humans and nonhumans gain power by increasing their number of associations (Murdoch 1996). Here many links, which many be in and of themselves not strong, if increased, can make an actant 'powerful' (Latour 1996a). Therefore, no actant has power prior to associations; power is an effect of them (Law 2009). Likewise, a successful innovation is not a result of a lone genius inventor but the actor-network that 
they could assemble by interesting others (Latour 1996). In associations with their varied power relations, actants gain their "attributes" and power through translations (Callon 1984). Therefore, power is only gained through increasing association and is not some inherent characteristic of any actant (Murdoch 1996; Latour 2005).

Often "inscriptions", be they scientific data or government records, extend and help increase power as it helps one "assemble many allies in one place" (Latour 1990:23). Power is not purely a social phenomenon. Science introduces new actants. New forms of argument and techniques invariably effect both nature and society (Latour 1993). The laboratory is not an isolated space of pure scientific inquiry. Instead, its findings can help remake its scales and dramatically increase its power as it marshals support from an ever-greater number of nonhumans and nonhumans (Latour 1983).

For Law and Singleton (2013) actor-networks demonstrate not only “power over" whereby one actant dominates another. There is also the "power to" inspire, suggest or interest another course of action. Both humans and nonhumans can "interest" other actants. Therefore, each holds forms of power (Bennett 2009; Callon 1984). With this view of power, which is heavily influenced by Foucault (Latour 1996a; Law and Singleton 2013), ANT scholars specifically avoid conceptions of power only as a kind of "power over" (Law and Singleton 2013) and as "the overarching powers of society, the huge asymmetries, the crushing exercise of power," (Latour 2005:72).

Some scholars argue that this concept of power, this will to extend an actornetwork is simplistic (Whittle and Spicer 2009) if not deterministic (Lee and Brown 1994). This debate is not dissimilar to that of structure and agency. Some assume that there is a rigid, powerful actor-network which pre-exists associations (Star 1990). If one 
does not wish to trace how such "power over" and "power to" is produced, then one has abandoned ANT (Law and Singleton 2013). Also, if power exists outside of associations, or is at the least little affected by changing associations then Latour (2005) is right to say there is little room for contestation. The moderns long played a dangerous game while alternating between an all-powerful and unchanging nature and society (Latour 1993) that helps to neutralize politics and leave power in the hands of 'experts' (Latour 2004).

I hope that the self-proclaimed 'radical' scholars opposed to ANT, who seem always at the barricades to save humanism (Whittle and Spicer 2009), analyze power relations to upset their asymmetries and not wallow in their impotence to affect change in the face of overwhelming structures. Latour (2005:252) argues that such totalizing conceptions of power are: "an extreme case of masochism, a perverted way to look for sure defeat while enjoying the bittersweet feeling of superior political correctness." Contrarily, Law and Singleton (2013:500) argue: "To the extent that ANT explores the contingencies of power it also generates tools for undoing the inevitability of that power." Similarly, Latour (2004) argues that politics is the "progressive composition of a common world" that includes humans and nonhumans whereby Society or Nature cannot easily intervene to solve controversies but are a part of complex debate and negotiation. Naïve or not, there is far more hope in ANT's accounts of power than those that posit massively powerful structures and separate, all but powerless agents.

\section{E. Symmetry of Actants and Outcomes}

ANTs use of "symmetry" ties together many of the above "sensibilities" (Callon 1984; Latour 1993). The idea of "symmetry" in science studies originates from Bloor's work that attempted to explain both true and false beliefs (Latour 1993; Murdoch 1996). 
Successful and unsuccessful projects are subject to the same analyses without assuming success and failure were preordained (Clarke 2002).

While ANT agrees with this "symmetrical" aim, Latour (1993) criticizes that Bloor and others wanted to explain scientific theories through social means and through various interests without looking at the materiality and actual "construction" of scientific knowledge in laboratories. These attempts at symmetry argue that nature is something unchanging and posit that society is the prime mover (Callon 1984). Often, they also assume that society is messy, but that nature was orderly and transcendent or vice versa. Their approach was hardly symmetrical, but rather was quite asymmetrical in how it dealt with nature and society (Latour 1993). In fact, they used a different set of tools for analyzing society and of nature, while maintaining an ontological break between them (Callon and Latour 1992).

These "asymmetrical" studies do not allow scientists to discuss theories of society and only listened when they spoke about nature. They deny that discussions of society are just as controversial as those of scientists discussing nature. Instead, ANT or the "sociology of translation" does not assume that debates regarding nature or society are free of contestation (Callon 1984). Latour (1993) argues that if some in science studies are willing to investigate how science can transform society, they are less interested in how social science can transform scientific understandings of nature. Nature all too often remains distant and transcendent in social scientists' accounts (Latour 1993).

For Callon (1984), practicing "generalized symmetry" can avoid these pitfalls. First, the investigator should not "censor" scientists when they discuss the social or when social scientists talk about nature. Secondly, one needs to use the same vocabulary when 
discussing society and nature. Third, practicing "free association", the investigator should not begin with fixed ideas of what entities 'belong' to nature and society prior to researching them.

Instead, ANT does not want to provide social explanations but instead investigate society, which too consists of humans and nonhumans (Latour 1990a, 1993; Callon and Latour 1992). ANT is not claiming that there are no differences between humans and nonhumans, or that they are "symmetrical" (Latour 2005; Callon and Latour 1992), but rather does not assume what effects they will create (Callon and Latour 1992). Generalized symmetry breaks down such divides and expectations (Callon 1984).

\section{F. ANT as Method}

ANT as a research method is definitively not as clearly codified as those found in methods textbooks such as participant observation or semi-structured interviews (Bernard 2012). ANT as a method rarely offers such crystal-clear guidelines for practitioners (Latour 2005). Here, I will describe my understandings ANT's methodologies, and how I will work with them to my study of the changing actor-networks that led to the rise, fall and "relaunch" of French truffle production.

With ANT, one describes the material effects of what are often "heterogenous" associations of humans and nonhumans (Law 1992) by "following the players", the actants that "construct" an actor-network (Latour 1996). ANT analyzes such associations, both textual and non-textual phenomenon alike through semiotics (Latour 1996a) or as with ANT's attention to materiality, through "material semiotics" (Law 2009). In material semiotics entities are a "a continuously generated effect of the webs of relations" (Law 2009:141). In these "webs of relations" or actor-networks there is no "center" 
(Latour 1996a; Law 2009). Different "webs may be partially associated in endless different ways," (Law 2009:153). Instead of immediately explaining these "webs of relations" consisting of both humans and nonhumans, one first seeks to describe how actor-networks form and the actants whose associations compose them (Latour 2005; Law 2009). Here ANT seeks the how's and not the whys (Law 2009).

In these descriptions, ANT does not attempt to describe already stable entities often referred to colloquially as 'networks' like roads, nor is it discussing 'social networks' that contain only humans (Latour 1996a; 1996). These are "heterogenous" actor-networks, with nonhumans often mediating interactions between humans and nonhumans. ANT rejects any social or "technological determinism" but recognizes a far greater unpredictability in such heterogeneous relations (Law 1992). As its hyphen suggests, relations shape both actants and networks in actor-network theory (Law 2009). ANT never imagines a network and then looks for its actants or vice versa (Latour 1999). The two are co-constituting. As relations shift, ontologies of actants change (Mol 1999).

Similarly, an ANT analysis avoids conceptualizing any pre-existing structures and agents that are separate from them (Latour 1999; Murdoch 1996). It does not intend to reconstruct these structures (Clarke 2002). It would hardly be starting with a "clean slate" (Law 1992) to begin with large structural forces and how they affect and are affected by certain actants. Neither should one assume that 'macro-levels' are separated from the 'micro-level' (Latour 1999; Latour 2005). Latour (1999) relates the frustration many have with attempts to maintain their close attention to local sites and the materiality of individual agents and then trying to distance themselves from these interactions and abstract them to understand the macro level that seem to influence their behavior. Then at 
the structural level these local interactions are lost in the shuffle. For ANT, Society does not explain local interactions, but in fact it is vice versa.

Law (2004a) concurs that any assumptions that the local is less complex than the global is a grave error. Instead, local interactions are just as rich, if not likely richer than that of a distanced global. Furthermore, ANT never intends to arrive at the level of totalizing social order that would allow the researcher to seamlessly pass from the global to the local (Latour 1999). Instead global concerns such as forest cover change in the Amazon cannot automatically be understood at the level of the entire forest mass, but instead at local sites. Latour (1999a) describes, how international and interdisciplinary team take many measurements, many "inscriptions" of the forest to understand if its edge is increasing or decreasing. Only by leaving the bewildering complexity of the forest with their "inscriptions" can they 'reconstruct' an intelligible version of the forest.

To restore scallop aquaculture in St. Brieuc Bay, France, French scientists needed to travel to Japan to learn from scientists there before trying to "translate" these techniques and "mobilize" fishers, scientists, politicians and scallops back at their local site in France (Callon 1984). Here we have a series of local sites that can only be connected by considerable work (Latour 2005). When Pasteur wanted to prove that his vaccines could cure anthrax, it was not enough to demonstrate such results in the lab, but instead such networks needed to extend to working farms. To do so, Pasteur ensured that certain actants would remain so that his vaccines would work there as well. Yet in mobilizing many actants, Pasteur succeeded in having his laboratory work "interest" actants across France (Latour 1983). 
Spatial and temporal scales then are not a fixed or inherent property of actornetworks but are modified as associations change. Work by many humans and nonhumans is needed to extend actor-networks (Latour 2005). In other cases, different actants' conception of time and temporal proximity will widely vary as some will link past events to present ones while others will not (Latour 1996). One cannot assume the even march of time or clear breaks with the past (Latour 1993). Instead, just like spatial scales, "time must be constructed" (Latour 1990a). Also, instead of actants having always existed, actor-networks must make the impacts of their actions or "traces" known. As in the case of Pasteur's microbes, actor-networks needed to prove that they existed and that they could be vanquished (Latour 1983).

\section{G. Where, When and How to Begin Describing Actor-Networks?}

One profoundly practical methodological question follows: From where and when should one start to describe an actor-network? If ANT is "embedded in practices"; actants must engage in these practices somewhere (Law and Singleton 2013). Again, there is no center of an actor-network (Law 2009). At the same time, one cannot appeal to structural factors that exist outside of actor-networks (Latour 1996a). One must follow "material semiotics" as entities interact and define themselves in local sites (Law 2004a; 2009).

One does not take structures or the actants "competencies" for granted (Latour 1993). Instead, one examines how entities "circulate" and take their shape (Latour 1999) in heterogeneous associations (Law 1992). In such associations, ANT allows actants to set the investigations' frameworks (Latour 2005). Showing ANT's influences from ethnomethodology, Latour (1999:19) argues "actors know what they do and we have to learn from them not only what they do, but how and why they do it." 
Even taking the above points into consideration, Latour (1996) clarifies that there is no clear starting point or end for describing actants' trajectories, or what he calls "following the players" through space and time. Clearly there are many methods in the traditional sense through which one can follow the players and describe associations in actor-networks (Latour 1996; 2005). Yet without a center to actor-networks (Law 2009), the exact physical or analytical starting point is not of grave importance. One will follow the players as they create new temporal and spatial scales. The researcher stops when leads disappear or their time and money is gone (Latour 1996).

Busch and Juska (1997) convincingly start by analyzing attempts to convert rapeseed oil from something that was unsafe for humans to how it was made safe for human consumption and rebranded as canola oil. Such transformations allowed canola oil to enter the global economy. Eventually political pressure allowed it to be exported to Japan. Pressure from the USA and Canada opened Japanese comestible oil markets, but Japan retained the rights to process canola seed into oil. Japanese firms then captured much of the added value. These various actor-networks required "translations" and "worknets" to function and to extend in time and space (Callon 1984; Latour 2005). It is conceivable that one could have started with the Japanese processing of canola seed, then followed the traces of this actor-network to Canada. One could have also followed efforts to change trade policies back to relations that transformed rapeseed oil into canola oil. Clearly, Japanese oil processors, Canadian canola seed growers and their associations and US soybean growers all become actants by creating effects. Busch and Juska (1997) show how no single entity could control or dictate associations. Power 
dynamics were ephemeral. Therefore, there was no clear, unmediated flow, but like many global value chains, canola oil experienced "friction" (Tsing 2011).

Similarly, Tsing's (2015) research collective "Matsutake Worlds" follows the matsutake mushrooms, an ectomycorrhizal mushroom like the truffle, around the world. The value chain extends from the USA, China and Japan with pickers, buyers, sellers and consumers in each place. While Japan is the 'home' of the matsutake, changes in forest cover and rural abandonment helped drive ecological changes there that made these mushrooms rarer and more expensive in Japan. After the discovery of a similar mushroom in the US Pacific Northwest, value chains emerged whereby independent pickers had the "freedom" of having no bosses. Pickers would "salvage" mushrooms from former industrial timber forest "in ruins" to begin to "construct" commodity chains that stretched back to Japan.

This 'multi-sited' nature of this study further destabilizes Japan as the center of the matsutake actor-network, or what Tsing (2015) calls multispecies worlds. Japan was no longer the principle producer, but still the principle market. Mushrooms from China, the USA and elsewhere flowed there, while most Japanese matsutake were consumed domestically. Even if changing Japanese demand heavily influences prices that US pickers receive, Japanese buyers depend on US harvests. Again, one could start with US pickers and follow "value chains" to Japan, or start in the USA and understand that while these pickers sold primarily to Japan. China also shipped matsutake to Japan.

These examples show that the starting point that one chooses to follow the players (Latour 1996) in a well-done ANT analysis is not of the greatest consequences as one will shift spatial and temporal scales with actants (Latour 2005). As Law (2009:147) 
argues "there is no overall social, natural, or conceptual framework or scale within which events take place: as webs grow they tend to grow their own metrics." While Latour (1996) admits that investigators' time and budget restrictions, may limit how far one can follow the players, the researchers should not begin with set ideas of spatial and temporal scales and ignore anything which does not conform to such preconceptions.

Suggestions such as following the players or tracing actor-networks, the sociology of translation or material semiotics all suggest remaining with the relationality and materiality of actants. Both humans and nonhumans will remake social and natural worlds in the process (Callon 1984; Latour 1996, 2005; Law 2009). Still there are the 'practicalities' of how one will actually follow actants. The first major ANT studies were ethnographies of scientific practice in laboratories to understand the materiality of scientific knowledge production (Latour 1987; Law 1992; Murdoch 1996), a tradition which has continued (de Laet and Mol 2000). Methods used in ANT investigations have also expanded.

Law (1987) and Latour (1983) each used archival sources to explain how actornetworks extended and were sustained by humans and nonhumans. Latour (1996) analyzed documents and interviewed politicians, engineers and other important actants in the attempt to build a mass transit system called Aramis. Robbins (2001) analyzed remotely sensed images to understand how nonhuman actants frustrated human intentions of land use zoning and planning. Latour (1999a) conducted participant observation with scientists studying forest change in the Amazon. We can see there are ways to experience the "sensibilities to the materialities, the relations and the specificities of the world, sensibilities that explore how matters get assembled precariously for a moment," (Law 
and Singleton 2013:500). I would argue then that the above traditional methods from archival work to participant observation to remote sensing help to develop and facilitate these sensibilities or sensitivities. These methods in various ways help ANT practitioners to ascertain the attributes and competencies of actants, of those entities which created effects and which were affected (Latour 1993).

\section{H. How to Follow Both Humans and Nonhumans?}

Beyond the question of which methods are appropriate for an ANT scholar, other important concerns remain. Critics have raised questions about how one demonstrates that nonhumans are in fact actants (Taylor 2011; Whittle and Spicer 2009). Callon and Latour (1992) describe how critics howled at how they felt that Callon (1984) claimed to understand scallops as actants without formal training in marine biology, which to me seems like a wicked rehashing of the "Great Divide" that separates humans and nonhumans (Latour 1993). Callon (1984) does not claim that scallops intentionally failed to anchor or that they have or lack intentionality, but that one should not make assumptions either way.

The test for actants is not whether one can 'prove' an actant's intentionality in creating effects, but that scallops no doubt helped undo the aquaculture scheme. They affected and were affected by both humans and nonhumans. Instead, Callon (1999) adheres to a kind of "radical indeterminacy" that does not presume anything about the capacities of humans or nonhumans outside of their relations. Robbins (2001) does not attribute intentionality to the tree species which expanded beyond the forest and invaded agricultural areas, which frustrated human attempts at land use zoning. Tsing (2015) argues that matsutake mushrooms only became common in the US Pacific Northwest 
after industrial logging had left the forest in "capitalist ruins", while pickers "salvaged" mushrooms there. There is no attributed intentionality to logging companies as if they secretly had wanted to produce mushrooms all along.

Bennett (2009) describes how observing or interacting with nonhumans demonstrates a kind of "thing-power" which affects humans by creating effects and affecting other actants. While other approaches may explain these effects as purely the product of human consciousness, ANT does not deny agency to the nonhuman affecting humans (Latour 2013). Bennet (2009:5) writes of seeing a dead rat, a glove and other "things" in a street gutter: "In this assemblage, objects appeared as things, that is, as vivid entities not entirely reducible to the contexts in which (human) subjects set them, never entirely exhausted by their semiotics."

Haraway (2008) explains how dogs were not "domesticated" by people but as they interacted and formed attachments with humans. They too are actants in domestication. In their study of “dispositifs of passion”, Gomart and Hennion (1999) study the real effects of music and drugs on their human "amateurs". Humans and nonhumans can be "partners in interaction". Likewise, lawn grass inspires people to care for this grass and involve themselves in fertilizer and pesticide markets in their attempts to maintain a perennially green lawn (Robbins 2012).

Law (1992) describes how his overhead projector helps sustain interest between himself, the instructor, and his students by "mediating" their interactions. The class with and without the projector is different in various ways. A similar case of "mediation" between humans and nonhumans is how instead of vocally imploring and posting signs requesting that guests leave their keys before exiting the hotel, hotel managers decided to 
put a heavy weight around the keys to remind guests to do so (Latour 1990a). Similarly, instead of asking drivers to maintain the posted speed limit, a speed bump, or 'sleeping policeman' will mediate behavior for drivers to do so (Latour 1992).

In other cases, it is the breakdown or absence of nonhumans like the case of a broken "door closer" that raises complex questions of substitution (Johnson 1988). De Laet and Mol (2000) show how Zimbabwe villagers had to exhibit ingenuity in fixing "bush pumps" that were meant to provide clean water but often broke down. Instead of a single fix, across the country, the bush pump showed marked "fluidity" as many different improvised repairs allowed it to function even when it missed parts that were thought to be vital to its functioning. Latour (1996) shows with Aramis that innovation requires not only budgets and political will, but engineers who can invent new technologies and solutions. At the same time, these engineers will discuss 'political' causes of a project's failure, just as politicians will discuss 'technological' setbacks that kept the mass transit system from being built. Bennett (2009) in analyzing an electric blackout argues that neither greedy energy traders, power plant managers, fires or constraints on how far reactive power could travel alone caused the blackout. Instead agency was 'distributed' in this assemblage of humans and nonhumans.

Humans also record human and nonhuman action through "inscriptions" (Latour 1999; Callon and Latour 1992). Laboratory instruments record the behavior of nonhumans through inscriptions in data, charts and tables (Callon 1984; Latour 1990). Scientists can use these inscriptions to extract data from one local site, and analyze it many miles away (Latour 1999a). Latour (1990) describes a mapping exhibition when a French geographer had informants draw a map of the island he intended to survey. It was 
only through the addition of standard latitude and longitude measurements that made it presentable and combinable with other maps and a "immutable mobile" (Latour 1990). As Latour (1999a:30) writes: "the sciences do not speak of the world, but rather construct representations that seem always to push it away, but also bring it closer."

Similarly, Latour (1993) describes how Boyle's construction of his air pump made it possible to 'prove' the natural existence of the vacuum and to construct facts in his laboratory. The air pump acted as a more dependable spokesperson to the existence of this phenomenon than any human could be. Pasteur would only test his anthrax vaccines on farmers if conditions closely resembled the laboratory conditions where it was first developed (Latour 1983). As Latour (1987:29) writes, "the construction of facts and machines is a collective process".

\section{Vocabulary, Reflexivity and Power in ANT}

Writing, the act of "describing" actor-networks is an important part of ANT methodology. The choice of vocabulary and ways of "describing" actor-networks is crucial for ANT (Callon and Latour 1992), which is not surprising given ANT's connection with semiotics (Callon 1984; Law 2009). As for as ANT's vocabulary, Latour (1996a:375) argues that ANT's vocabulary “is more an infralanguage than a metalanguage. It is even less than a descriptive vocabulary; it simply opens, against all a priori reductions, the possibility of describing irreductions." ANT then tries to avoid such "reductions" with the terms "actant instead of actor, actor-network instead of social relations" (Callon and Latour 1992). Again, the term "actant" does not discriminate between humans and nonhumans or demand that actants demonstrate clear “intentionality” (Callon 1984; Latour 1996a). 
One then does not switch registers to explain social and technical assemblages differently (Callon 1984). ANT's use of an "infra-language” attempts not only to be anthropomorphic or "zoomorphic", but instead one that is applicable to humans and nonhumans alike (Latour 1996a). This vocabulary allows one to transcend divisions between nature and society and not grant stronger agency or capacities to humans or nonhumans (Callon and Latour 1992).

Lee and Brown (1994) admit that ANT has successfully helped collapse distinctions between humans and nonhumans, but also argue that these processes have potentially gone too far. While ANT they acknowledge that has managed to bring "nonhumans back into the sociological fold", it has done so under appeals appealing to a kind of "liberal democracy" to include more nonhumans as actants. Furthermore, they feel that the collapsing of these distinctions can eventually lose differences between actants as ANT creates a "final, final vocabulary" that is unrealistically applicable to all actants, always.

Latour (2013) does not find ANT's vocabulary as 'totalizing' as Lee and Brown (1994). He argues similarly that ANT does important work in breaking down these distinctions but may be incapable of differentiating between different actor-networks. Without assuming some 'essence' 'existed all along', Latour (2013), in An Inquiry into Modes of Existence, seeks to understand what kind of relations produce the "effect" of "legal" actor-networks and how these differ from say, a "religious" actor-network.

Latour (1996a) argues that ANT can aid social scientists in another longstanding difficulty - that of reflexivity. Instead of a distanced observer explaining or representing "events in an external reality, ANT does not maintain such divisions as "the frames of 
reference are granted back to actors". Actants set frames and place their actions within these frameworks (Latour 2005). The observer does not have a privileged frame of reference compared to other actants (Latour 1996a). Instead of embracing relativism, Latour (1996a) argues that the observers' relations must lead one from their account to "all other accounts". The researcher does not want to produce an account that is entirely unrecognizable by their informants (Latour 2005).

Elsewhere, Latour (2005:150) writes that "most of what social scientists call 'reflexivity' is just a way of asking totally irrelevant questions to people who ask other questions for which the analyst does not have the slightest answer!" In a more conventional look at reflexivity, Law and Singleton (2013) state that the "observer" or ANT scholar "makes choices" about what actants to include. Such choices may even depend on one's “own agendas, political, theoretical, personal." One's "ethnography" and "what people are saying" of course guides research as well.

Law (2009) argues that writing, describing entities through ANT is an intervention into the world. Through ANT one does not study something 'out there'. Therefore, the researcher can become an actant in these actor-networks. ANT intervenes by "working in the world" (Law and Singleton 2013). Research in ANT, does not merely describe reality but "enacts" it as well as actor-networks mobilize or fail to mobilize allies (Law 2004). For Law (2004:7) “social (and natural) science investigations interfere with the world, in one way or another they always make a difference, politically or otherwise."

For Latour (2004) the transcendent category of capital-N Nature undercuts politics. Instead of trying to defend conceptions of reified Nature, political ecology needs 
to attend to humans and nonhumans that "compose" the world. Politics, ANT or otherwise, center around the "progressive composition of a common world" and when to continue or stop admitting new actants into this common world. Politics cannot occur after "the states of the world have been defined". ANT seeks to counteracts appeals by experts to Nature which can demolish politics.

Another way of 'intervening' in the world for ANT is through re-conceptualizing power. Law and Singleton (2013:500) argue that "to the extent that ANT explores the contingencies of power it also generates tools for undoing the inevitability of that power." Again, actants do not somehow enter actor-networks with power. Power is an effect of assembling or failing to assemble allies (Callon 1984; Latour 1983). In these "web-y" relations both human and nonhuman actants each have the "power over" and abilities to dominate other actants but also the "power to" affect others and offer new capacities to actants and produce less certain outcomes. As relations change, so does "power over" and "power to" in relations. This view of power, like much ANT, continues to frustrate those who imagine fixed, rigid structures and preexisting 'dominating' power dynamics (Law and Singleton 2013).

ANT does not assume that a singular reality dominates which is understood through multiple perspectives (Law and Singleton 2013; Mol 1999). Different actornetworks, as in the case of the diagnosis of "anemia", produce a kind of "ontological multiplicity" of different anemias (Mol 1999). Multiplicity extends to areas where singularity presumably had dominated: "The West, then, if it is opened and studied, is not 'naturalist': it does not 'have' a single nature and many cultures. Instead, it orders heterogeneous realities in a variety of ways," (Yates-Doerr and Mol 2012:49). 
This supposed singular "Nature" was one way of maintaining the "Great Divide" between 'the West' and the non-West (Latour 1993). These ontological "multiplicities" are "performed" through "heterogeneous" associations in actor-networks (Law and Singleton 2013). For Muller (2015:31), "seeing the world as performative has important implications for an ontological politics: it means that it can and indeed should be shaped by everyone and that knowledge about the world is contingent and not the prerogative of experts." By opening “ontological politics" to experts and non-experts alike, ANT scholars can intervene in making accounts true (Law 2004).

\section{E. My Treatment of Reflexivity and Power in Truffle Actor-Networks}

I agree with Latour (1996a) that the "infra-language" developed by ANT scholars is vital to working with and adding to ANT's repertoire of case studies (Mol 2010). It is clearly not a simple or intuitive "infra-language" as Latour's (1999b) guide to itself vocabulary suggests. Yet the word actant does avoid so many preconceived anthropocentric notions of "actors" (Latour 1996a; Latour 1999).

I will stick to a more traditional version of ANT. I will not engage at any length with Latour's (2013) Inquiry into Modes of Existences and try to differentiate between the actor-networks. I feel that describing alternative actor-networks to "modern" trufficulture is enough work for now. Nor do I see any danger in the "totalizing" potential ANT as a final, final vocabulary (Lee and Brown 1994). Capturing the differences of opinion between truffle scientists, trufficulteurs, syndicates/associations and other actants does not make me worry about any totalization of the actor-networks that I describe.

I agree with ANT as well that I cannot imagine that I can represent an external reality (Latour 1996a). I do not pretend that I am a disinterested and objective chronicler. 
Of course, I have my "own agendas, political, theoretical, personal" (Law and Singleton 2013:495) that likely will impact this research. Throughout the research I was taken in by the generosity, of people from Lot, the Lotois. I was caught up in the passion they had for the truffle and become obsessed.

At the same time, I became convinced by talking with Organic farmers in Lot, just how ill-adapted "modern" agriculture had been there. A single, inflexible or "scalable" (Tsing 2015) version of agriculture was implemented in Lot. I understand how many farmers had decided to sell their farms and how many more were on the brink of doing so. I became increasingly suspicious of any idea that these farmers were somehow backwards or inefficient and that they should no longer farm. The food they produced with all its it rich and complex flavor. Such food was a testament to their techniques.

Their polyculture systems evoked the past but were situated towards securing livelihoods and subsistence in the present. Saving the rich gastronomic tradition of Lot and relaunching trufficulture both seemed to hinge on retaining existing farmers and attracting thousands more. Relatedly, I became convinced that instead of ongoing and unchecked reforestation, deforestation will likely be needed to accommodate these new farmers and trufficulteurs. I methodically imagined these actor-networks throughout the course of this investigation. I discuss them more in Chapter 6.

My helpful interviewees commented on how lucky I was that I had the time and funds to spend my time talking and working with so many trufficulteurs in Lot and "following the players" (Latour 1996) around Lot. People seemed less envious of my months of searching for traces of the truffle in Lot's départemental archives, though I 
enjoyed this archival work just as much if not more. Indeed, I enjoyed every minute of research. Without a doubt I caught the "passion", the "virus of the truffle" too.

Once syndicate members realized that I had caught the virus of the truffle as well, they offered their hypothesis regarding the past, present and future of trufficulture in Lot. Often, I heard the same narrative of how phylloxera had nearly destroyed viticulture in Lot. In response, people had planted truffières to recoup lost income. Yet by WWI people either died at the front or left seeking better economic opportunities. Farms could not survive. The truffle went into decline. Then people again become interested in the truffle. They replanted. They convinced their friends to do so. Despites these efforts, the truffle remained unpredictable.

Instead of trying to immediately critique this account, which seemed to have become almost common sense in Lot, I followed ANT's ethnomethodological influences and adopted these frameworks. Yet, a good ANT analysis is judged by the richness of its descriptions (Latour 2005). I wanted to check the veracity of these accounts, and if correct, to quantify and "qualify" these changes, to seek the kind of "materiality" that these broad accounts did not provide. Few other scholars had seriously examined the truffle's history (Bye 2000; Bye et al. 1998; Castelnau 1978; Chazoule 2004; Lauriac and Diette 2004; Mayssonnier 2010), so I knew there was much to discover. As a non-farmer and social scientists, I felt my strongest intervention would be to fill in the fascinating details of the historical frameworks that my informants had provided me.

Additionally, the scale of agricultural abandonment and "forest resurgence" (Hecht and Saatchi 2007) in Lot shocked me. The trufficulteurs I interviewed in Lot described how landscapes' transformations hurt current iterations of trufficulture. Instead 
of blaming scientists or trufficulteurs for often underwhelming yields (Callot 1999; Mayssonnier 2010), I began to seriously look at the actor-networks that produce such an unfavorable landscape. Following ANT, I tried to rethink relations that spanned new temporal scales (Latour 1993; 1996a). It seemed that "modern" trufficulture dominated all talk of trufficulture in Lot, despite its expense and unpredictability. I returned to the archives to understand truffières' past as a means of comparison. These truffières were far less purified (Latour 1993) from their surrounding landscapes than "modern" ones which are surrounded by chain link or electric fences to keep out deer and wild boar. For me, these past truffières might provide import alternatives to current attempts to disconnect trufficulture from its broader actor-network.

Also looking to the past, Diette and Lauriac (2005) describe methods of "truffle silviculture" that could "renovate" and "rehabilitate" these reforested areas and make them produce truffles again. By pursuing Lot's iteration of truffle silviculture as an alternative, but not a replacement for modern trufficulture, I feel I am engaging in a kind of "ontological politics" (Mol 1999). Instead if former agricultural land must be translated into a "modern" truffière through considerable labor and monetary investments, one can work with Lot's ever-growing forested area as a potential truffière.

Modern agriculture had moved to the flattest and most fertile areas in Lot and led to the abandonment of much of the rest, which in Lot was not much land. "Modern" trufficulture follows this model and only 'cultivates' land most suitable for the truffle. These forests, some of which are abandoned truffières (Champagnac 2000), may be brought back into production with much less financial investment. Truffle yields do not have to be high to improve current revenues (Diette and Lauriac 2005). 
Such thinking also abandons the likely erroneous notion that "modern" trufficulture can gain "power over" the truffle and "tame the truffle" (Hall et al 2007; Law and Singleton 2013:493). Instead, by bringing trufficulture back into associations with forest silviculture and silvopastoralism, these actants may have the "power to" increase production. These alternative practices may also have the "power to" interest the large number of farmers put off by the kinds of large investments and uncertain returns that plague many "modern" truffières (Callot 1999). Such techniques may give "new capacities" and lead to unpredictable outcomes (Law and Singleton 2013). While experts still pursue a "singular" "modern" trufficulture but with different perspectives or “methods" (Chevalier and Pargney 2014 Muller et al. 2015).

It is with these interventions, by following actants onto less trodden paths, that I seek to engage in politics ANT-style through the "progressive composition of a common world," (Latour 2004:18). I do not argue that trufficulteurs should abandon "modern" trufficulture, but instead that a "multiplicity" of actor-networks can exist, ones that may have the "power to" offer alternatives to Lot's recent landscape transformations instead of only looking to have "power over" it. I realize that I must "mobilize" both humans and nonhumans (Callon 1984) as a non-scientist, non-farmer and American social scientist.

Following Callon's (1984) framework for the "sociology of translations", I have described the "problematization" that I will pursue, the rest of this work will need to engage in interessement, to set the stage for other trufficulteurs. "Enrollment" will be a longer, ongoing processes. The "mobilization of allies" and my ability to act as one of my "spokespersons" for these alternatives, but with the slow pace at which trufficulture 
moves, it will take a long time to see if these efforts are successful. With my "passion" for the "thing-power" of the truffle (Bennett 2009), I will gladly see it through.

As described in this chapter, ANT functions both as my principal theory and methodology. By discussing its theoretical and methodological applications, I have hoped to highlight ANT's diversity and flexibility, while clarifying its components that I find most useful for my study. Above all, it inspired an openness to all possibilities for this research. I admitted any actant that produced effects, and as much as possible, tried to follow them across time and space. In the subsequent chapters, both humans and nonhumans, often acting in intense hybridity, revolutionize trufficulture in Lot. 
Chapter 3: Lot's Tumultuous "Golden Age" of the Truffle

\section{A. Introduction}

In this chapter I describe the actor-network which produced Lot's highest historic truffle yields. In the first half of the chapter I show how high rural population densities, deforestation and phylloxera helped prepare landscapes for a surge in truffle production. While it may seem misguided to start a dissertation ostensibly about truffles with a detailed examination of Lot's grapevines and wine production, I will demonstrate that it is impossible to remove wine and the phylloxera epidemic from the truffle's actornetwork. Next, I describe Lot's truffle “golden age” in detail. Here I provided unparalleled detailed data regarding truffle yields, prices and hectares under cultivation. I demonstrate that the truffle provided substantial economic benefits. Such income was crucial in the wake of the phylloxera epidemic, which had ruined many farmers.

\section{B. Describing the Département of Lot}

The département of Lot, like any other actant, was "assembled" (Latour 2005). It was the French Revolution that helped to create the département of Lot and divided the pre-Revolutionary province of Quercy. Quercy’s capital was Montauban, though Montauban would later would become the capital of its own département, Tarn-etGaronne (Delpon 1831; Gluck and Gluck 1852). Cahors would become the capital of the new département of Lot. Lot was further divided into three arrondissements, Cahors, Figeac and Gourdon. The arrondissement of Cahors is the largest in size at 221,671 hectares, Figeac is second with 158,298 ha and Martel is 144,430 ha for a total of 524,399 hectares. Each arrondissement is further divided into cantons, which are made up of communes, which can include a single village or various hamlets as well as their 
surrounding forests and farmlands (Delpon 1831). These administrative divisions are further important for my data-gathering as the archives were frequently taken separately for different communes and cantons in each arrondissement, which not only slowed down the assembling of data for Lot, but also seemed to increase discrepancies and gaps in the data. Only in certain occasions is aggregate data available for the département of Lot, which complicates analysis. Different forms would collect data in variety of forms and seem to favor gaps in data. In some years actor-networks were presented in a stabilized form with totals for all crops, including truffles in Lot. In other years, archives included communal data collection sheets, which meant that I needed to examine roughly half of Lot's communes, which regularly or occasionally produced truffles. These years, I need to arrange and total truffle and other data to even have a picture of Lot as a département.

The principal rivers in the département are the Dordogne and its main artery, the Lot, for which the département, like many others in post-Revolutionary France, is named. Even though the original Toulouse-Paris road passed through the département, its main commercial connection prior to the arrival of the railroads was the Lot River which would meet the Garonne River on its way to the port city of Bordeaux (Gluck and Gluck 1852; Baux 1982). While products could travel over the tough roads north to markets in the Massif Central in the country's inland center (Delpon 1831; De Lamberterie 1874), their reliance on the Lot River to bring products to Bordeaux would present many difficulties for viticulturalists in Lot (De Lamberterie 1874).

Here we can see how networks in their more literal sense of riverine trade networks impact Lot's viticulturists. In the $18^{\text {th }}$ century they would rely on Bordeaux and 
its trade laws. Its actor-network, including efforts to make the Lot River navigable, fostered trading relations with Bordeaux's wine merchants. Such relationships would not be universally positive. Even after it severed its close ties with Bordeaux, viticulture was an actor-network in flux. This viticultural actor-network would revolutionize Lot throughout the $20^{\text {th }}$ century. This wine revolution would transform trufficulture as well, adding a newfound urgency to trufficulture. A variety of disparate actor-networks from freer trade for Lot's viticulturalists, to change inheritance laws, to high farming populations densities to wine epidemics that first helped and later hurt Lot that would even make a "golden age" of trufficulture possible. Yet no single entity controlled these actor-networks nor set them into motion.

\section{Lot's Changing Wine Economy}

Lot's wines played an important role in Bordeaux's vinicultural actor-networks. Instead of maintaining their provenance when they arrived in Bordeaux, Lot's wines anonymously were often mixed or "cut" with wines from Bordeaux's famous regions like Graves, which did not always achieve a sufficiently dark red color and body, especially in years without sufficient sunshine. As Lot's best "black" Malbec wines were famous for their dark, impenetrable coloration, they would be cut into Bordeaux wines to improve the latter's color in years when Bordeaux's red wines were not sufficiently red, which would have hurt their value. Not only would Lot's wines be mixed with Bordeaux's wines in secret, Bordeaux's winemakers would blame Lot's wine for any perceived defects (Larue 1906). Therefore, only to the most knowledgeable would understand the associations necessary to maintain the reputation of Bordeaux's wine, at the expense of Lot's. Its two thousand-year viticultural tradition all but disappeared at it was an 
unacknowledged colorant in Bordeaux's wine (Delpon 1831; Velasco-Graciet and Rouvellac 2002; Larue 1906).

This often secretive "cutting" was not the only prejudicial aspect of Bordeaux's relationship with Lot's viticulturalists. Bordeaux had also long restricted free trade and the importation of wines from September 8th to December 25th, to sell local wines first (De Lamberterie 1874; Larue 1906). The other major port of Marseille also set up barriers to free trade, which meant that Lot's winegrowers could only realistically sell their wine without restrictions in Toulouse (Larue 1906). Therefore, even though Lot was selling unprecedented amounts of wine, it was not always recognized as even being wine from Lot until a few decades after the French Revolution. Yet once comparative "free trade" arrived, Lot's winegrowers sold their wine wherever and whenever they liked. Lot's wines would not literally disappear into other wines as they circulated. They could regain the centuries old esteem as they could circulate and be sold with their provenance intact (De Lamberterie 1874; Delpon 1831; Larue 1906).

\section{An Overview of Lot's Agrarian Economy}

While "freer" trade and the end to Bordeaux's monopolistic practices helped Lot's viticulturalists, many accounts by scholars and bureaucrats regarding the state of Lot's agriculture were not highly optimistic. Even when the quality of grapes and other produce was high, quantity lagged the rest of France (Delpon 1831; Rey 1889). Agricultural remained preeminent as Lot had little to no industrial development as an economic alternative. Lot's economy was dependent on agriculture (Delpon 1831). De Lamberterie (1856) describes the département in the following way: 
"without industrial resources, which cannot live without sound transportation networks, the inhabitants of Lot are left even until now only with agriculture...their land is their only workshop and their only investment capital, which is disputed to shreds. They divide and subdivide their inheritances. There isn't a steep hillside, an arid plateau where they do not seek to create a field or vineyard. Their work increased but not their production. These lands cannot handle drought and are erosion prone. Once can now see them working hillsides that are three-quarters denuded of grasses and that the last generation has uselessly started to cultivate."

The above passage describes how for much of the 19th century deforestation was a concern in Lot on the causses and elsewhere, especially as ever smaller parcels needed to provide subsistence (Valserres 1874). The sale of public and church lands meant that many more people than before the Revolution owned property. Instead of managing this land as forest, many deforested their newly acquired lands as they had to wrest subsistence from small parcels (Baux 1982). Lot's forest, primary Quercus pubescens on the causses were of little value (Delpon 1831). Once cleared, these lands became more intensively managed under Article 826 of the Napoleonic Code, which states that each potential inheritor could ask for an equal division of the real estate and related property. These changes meant that already small farms were often further subdivided between each child, who all needed to earn a living from an ever-smaller holding, which meant more land came under cultivation (Ministère de L'agriculture 1869).

De Lamberterie (1874) argued it was the access to land and its successive subdivision that would bring an ever-greater surface under cultivation. Few forests were spared from the ax. Additionally, Baux (1982) argues the mid-1850s saw the peak population density for Lot's countryside as well as a cleared landscape with nearly every available surface under cultivation. With such high population densities, at potentially no 
time in history were there were more people in need of farmland in Lot. Changes in inheritance law meant that their heritors would gain access to this land.

Similar waves of deforestation became a concern at the national level (Pradel 1914; Valserres 1874). Officials were concern that such deforestation would provoke erosion which would cause entire towns to be carried away by floods (Pradel 1914). A major impetus for the growth of trufficulture in southeast France came as mayors and communes gained subsidies to reforest denuded lands with truffle oaks (Valserres 1874). Such clearing transformed landscapes into the open canopy landscapes in which truffles thrived (Le Tacon et al. 2014). Reforestation campaigns would make truffle production in départements like Vaucluse skyrocket (Chatin 1892; Valserres 1874). While such reforestation through trufficulture would transform certain communes from some of France's poorest to some of its richest (Bosredon 1887), trufficulture arrived later in Lot than other départements (Meulet 1889; Valserres 1874).

During his second assessment of the economy of Lot, Lamberterie (1874:1) writes in a more positive light that "Lot possesses important resources. Its population is healthy and vigorous." Yet his optimism is measured by the admission that "its soil is hilly, tormented, rugged and infertile..." Only in the valley and in select parts of plateaus was there any decent soil that would produce yields comparable to other areas of France. Rey (1889) says that while the soil of Lot was entirely "incapable of enriching its farmers" it could only provide them with basic subsistence, if that. Yet even basic subsistence necessitated "prodigious" work. Neither Rey (1889) nor De Lamberterie (1874) 'blame' the aptitude or work ethic of Lot's farmers for the state of agriculture there. Instead, they blame the steepness of the terrain, the poorness of the soil as well as the small subdivided 
plots of land that were not suitable to the cadre of agricultural machines that were being implemented elsewhere (Rey 1889). Lot would maintain its reputation as an undermechanized agricultural area for much of the $19^{\text {th }}$ century (Delpon 1831; Rey 1889). Extensive farming practices would lead to Lot's height of arable land (Baux 1982).

\section{E. Farming Lot's Causses}

Such agricultural limitations came largely from the fact that two-thirds of Lot $(\sim 311,000$ ha), mainly in the arrodissements of Cahors and Gourdon, was made up of causses land, which are arid lands with abrupt topographies, shallow calcareous soils laid down during the Jurassic era, and fissured subsoils with a dominant forest cover of low timber value made up of oaks (Chene pubescens) and common junipers (Juniperus communis). These are the same lands suitable to the truffle (Valserres 1874). While the above characterizations apply to all, Lot had three main causses from north to south, which are that of Martel, Gramat and Limogne (Rey 1889). While rainfall is highly "variable" and drought is common on the causses, rainy years are particularly rich for the growth of natural pastures there (Ministère de L'agriculture 1959).

The main land use of these 'natural' pastures on the causses was silvopastoralism. At the height of its sheep production Lot was the second highest shipper of sheep to Parisian markets (Direction Départemental de l'Agriculture du Lot Service du Génie Rural des Eaux et des Forest 1969). In such extensive silvopastoral systems, farmers would prune branches largely from oak trees and use these leaves as well to nourish their sheep (Rey 1908). Oaks also provided fuelwood (Direction Départemental de l'Agriculture du Lot Service du Génie Rural des Eaux et des Forest 1969). Such extensively managed and worked landscapes could produce truffles in "natural" truffières 
(Delpon 1831). Production of wool and meat, though, was highly variable. Droughts could desolate the causses, hitting their animals and people particularly hard: "when droughts arrive, the grass quickly disappears and doesn't leave any areas from being burned by the sun. Wool-producing stock are exposed to cruel suffering and perish in great numbers if there is no feed or leaves from trees," (Rey 1889).

The best of all causses farmland was capable of growing grapevines as well, especially on its steep hillsides (coteaux) and relatively flat plateau areas, which lead to further deforestation. Elsewhere on the causses the soil was unable in many areas to produce even wheat so many people grew rye for household subsistence (De Lamberterie 1880; Delpon 1831). Yet between periods of deforestation and 'excessive' reforestation, the truffle would bring value to the causses. The truffle was one of the few "cultures" that could at times thrive on the causses (Rey 1908) even though it was severely affected by droughts (Gay and Gromas 1937). Trufficulture on the case in Lot, as elsewhere existed in landscapes of sheepherding, viticultural, fuelwood harvesting and cereal cultivation (Bosredon 1887; Castelnau 1978; Rey 1889). Such practices not only helped create the kinds of open canopy forests within which truffles thrived, truffle scholars have argued that they make soils more suitable to trufficulture (Bosredon 1887). Polyculture systems dominated on the causses, where truffle production would surge (Rey 1908).

While such developments as deforestation, a large population of polycultural farmers would be favorable for trufficulture (Le Tacon et al. 2014), a tumultuous wine market would make actor-networks more receptive to truffle production.

\section{F. "Wine Madness"}


All this deforestation in Lot during the mid-1800s was not merely for household subsistence to support historically high population densities who had few options but to farm (Delphon 1831; Baux 1982). Fluctuations in wine prices would play a pivotal role as well (Rey 1908). While the destruction of Lot's vineyards by the phylloxera aphid would be the most "dramatic" episode of the 20th century for Lot (Baux 1982), the arrival of powdery mildew (l'oüdium de la vigne) in France also transformed Lot. While many trufficulteurs today in Lot cite phylloxera as a transformative actor-network for trufficulture, I displace the timeline backwards as powdery mildew, a fungus accidently important from the USA, led to a rapid expansion in the planting of grapevines that phylloxera would halt (Baux 1982).

Instead of facing similarly disastrous consequences as they would with phylloxera, powdery mildew had comparatively limited impacts, which meant that Lot was in a period of viticultural expansion with nearly 80,000 ha planted in grapevines. Planting expanding outside the traditional areas in the Lot River Valley (Larue 1906). While powdery mildew killed and weakened grapevines throughout France in the 1850s (Loua 1875), it had surprisingly little impact on Malbec grapevines grown in much of the département of Lot (Baux 1982). Archival documents show that only select communes were affected by powdery mildew. The commune of Montcuq lost only 1/20 of its harvests. The viticultural center of Luzech lost only 1/30 of its harvest to powdery mildew in 1859 (Département du Lot 1860). The fact that there is a paucity of documents about powdery mildew in Lot's départemental archives speaks to its limited impact. This seeming inherent resistance of local grapevines to downy mildew created a unique opportunity for winegrowers in Lot (Baux 1982). 
With many of France's top viticultural areas' yields suffering, viticulturalists in Lot rapidly planted to take advantage of low supply in France and high prices, a period often referred to as "wine madness" ( "la folie de la vigne”) (Larue 1906; Baux 1982). Baux (1982) describes how plateaus in Lot were quickly deforested or plowed under to plant grapevines. Next, farmers deforested steep hillsides (coteaux) and on the causses and planted wine there. The single canton of Luzech, which is located at the heart of Lot's historic wine-growing region in the Lot River Valley, had 7172 ha of grapevines in 1859 (Département du Lot 1860). The much larger canton of Martel, which is not even located in Lot's historic viticultural region near the Lot River, by 1852 would have 13,045 ha of wine (Département du Lot 1862). The price of wine during this period rose from 20 francs/hectoliter to 36 frs/hl (Lamberterie 1874), while Rey (1908) states that prices could rise even to 50-60 francs/hl. This prosperity would not only lead to the expansion of planting grapevines, but it would also lead to a boon in home construction from increasing wine revenues (Chauveau 1994).

Any piece of land remotely suited to viticulture was cleared and planted during this period (Rey 1908). The high prices had reinforced if not exacerbated ongoing trends. Even before the arrival of downy mildew scare, Delpon (1831) describes how grapevines became increasingly prevalent in the arrondissement of Cahors. There, winemakers produced "esteemed" wines, even if yields per hectare were often very low compared to other areas of France. He describes some communes whose hillsides were entirely covered in grapevines. Farther from the Lot River, communes like Payrac and St. Germain were extensively planting grapevines on causses lands. Vineyards on these lands could produce for 30-40 years, while those on more fertile lands could produce for 
up to 100 years. Wine madness had rapidly expanded viticultural in Lot. Spatially, its actor-network expanded far beyond historical levels. Even steep lands that produced good wine but low yields like the coteaux where planted. With such high wine prices, even Lot's notoriously poor soils could produce wealth (Chauveau 1994). Yet, as quickly as the spatial expansion of actor-network would be, its contraction would be more brutal.

\section{G. The Ravages of Phylloxera in Lot}

While the devastating phylloxera aphid had arrived in many other areas of France first (Société Française de Protection Contre le Phylloxera 1912), it was first reported in Lot in 1876 in commune of Labastide-Marnhac (Correspondance et rapports 1894). Others report 1874 as the data of phylloxera's arrival in Lot (Chambre de Commerce 1994), though the insect's lifecycle meant it would have impacts a few years after its arrival (Planchon 1875). The phylloxera aphid, like powdery mildew was accidently brought from America. The aphid arrived in France in around 1868.

It was further spread throughout France by trade and by its own wings. These two modes of transport meant that there were no "natural" barriers to restrain it (Planchon 1875). While one-third of France's grapevine for whatever reason remained unharmed by the phylloxera aphid, nearly all of Lot's would be killed (Département du Lot 1900). Their luck with powdery mildew would not repeat itself with phylloxera. By 1877, 80 communes were affected with the phylloxera aphid. By 1878, 120 communes were infected. The rest soon would be infected. Lot had a peak of 79,769 ha of pre-phylloxera grapevines (more than $1 / 6$ its entire surface), which plummeted to 60,4777 ha by 1883 . Of these 60,000 ha there were another 26,000 ha dead or dying and 22,000 which were under 
attack. Only 12,000 remained unaffected by 1883 (Société Française de Protection Contre le Phylloxera 1912; Correspondance et rapports 1894). Nearly all would be infected.

As one official in Lot said: "In a poor and steep country like the Department of Lot wine is the most remunerative crop and is more suited to the land than any other crop...the loss of our grapevines is an immense and irreparable misfortune," (Correspondance et rapports 1894). Rey (1889) wondered at the time of phylloxera if Lot itself "would be vanquished by these hostile elements or if we would have the means to victoriously resist them." For years after the arrival of phylloxera the first seemed more likely. Single viticultural communes like Cahors would have far more than 1000 hectares destroyed by phylloxera, while all Arcambal's vineyards would be dead or infected by 1883 (Société Française de Protection Contre le Phylloxera 1912). The brief bonanza of “wine madness” was over (Baux 1982).

While these dead grapevines were eventually uprooted to introduce other crops, including truffles, such changes came frighteningly slow. The arrival of phylloxera posed a longstanding crisis for grapevines, viticulturalists and the state. One official lamented that "public wealth is progressively diminishing and one of our principal sources of wealth will be lost soon," (Correspondance et rapports 1894). Officials would learn that 200,000 ha of grapevines had already been destroyed by the phylloxera aphid in the Rhone Valley. Debates over its cure raged (Campbell 2004).

Some argued that the only way to restore production was through "hybrid" plants that "grafted" French vines to American rootstock, which Planchon (1875) had demonstrated had immunity to the phylloxera aphid. He found that plant enthusiasts imported American vines to France. They did not understand they were importing 
phylloxera too. These plants and aphids arrived in France and put wine under existential threat (Planchon 1875). Despite an impressive actor-network of scientific interchange between French and American scientists that 'proved' the phylloxera aphid was the cause of the mass death of French vines (Campbell 2004; Planchon 1875), a vocal contingent in France, with its own ardent adherents in Lot, managed for a time to ban the importation of "American" plants, hoping to stop the aphid from spreading further (Correspondance et rapports 1894).

In response to phylloxera, many viticultural communes in Lot started their own “committees" to "defend" their grapevines against phylloxera. This aphid promoted human organization to counteract it. These committees were successful in lobbying elected officials in gaining tax-exempt status for some of the replanting after phylloxera. In other cases, they gained subsidies for experimental insecticides. Plant nurseries in search of profit appealed to these committees and the misery endured because of phylloxera: "the inhabitants of our lovely département of Lot, once fairly rich, are now desolated by the terrible scourge of phylloxera."

Sulfur and other chemical treatments did not prove effective, nor did "drowning" the insects with excessive irrigation. After a long and messy debate, a majority concurred that American plants could "combat this disastrous enemy of our grapevines," (Correspondance et rapports 1894). It was indeed the planting of "hybrid" plants that would take the first steps in ameliorating the situation (Société Française de Protection Contre le Phylloxera 1912). Eventually, Lot ended their ban on imported "hybrid" plants, stopped trying to kill the phylloxera aphid with chemicals and at last dedicated its efforts to "reconstitute" its vineyards through the planting of these "hybrid" plants. The 
département of Lot also created nurseries specifically tasked with producing these "hybrid" plants that were provided to viticulturalists either free or at highly subsidized costs, to replant and "reconstitute" vineyards (Société Française de Protection Contre le Phylloxera 1912). Yet the task of not only planting, but maintaining these "hybrid" plants alive would not be a simple task (Mouillefert 1904).

The following table shows the impacts of phylloxera and how Lot's viticulturalists dealt them. Unfortunately, exact data is not available for first 20,000 hectares that were lost to the phylloxera aphid during the first seven years of the epidemic. Amazingly, there is no recorded state response to such losses. The above description of debate and indecision suggest these hectares disappeared without much of a fight, consensus on the cause of their destruction or its remedy. That limitation aside, these data provide a window into attempts to use sulfur treatments, before these methods were abandoned in favor of the grafting of "American" plants. They demonstrate how after debate and infighting that the "hybrid" plant side won out. All hopes of reconstituting Lot's vineyards were placed on these plants.:

Table 1. The Impacts of Phylloxera and Its Remedies in Lot.

\begin{tabular}{|l|l|l|l|l|l|l|}
\hline Year & $\begin{array}{l}\text { Total } \\
\text { Ha } \\
\text { Grapevines }\end{array}$ & $\begin{array}{l}\text { Attacked } \\
\text { By } \\
\text { Phylloxera } \\
\text { But } \\
\text { Still } \\
\text { Resistant }\end{array}$ & $\begin{array}{l}\text { Destroyed } \\
\text { By } \\
\text { Phylloxera } \\
\text { Since the } \\
\text { Invasion }\end{array}$ & $\begin{array}{l}\text { Treated } \\
\text { Carbon- } \\
\text { disulfide }\end{array}$ & $\begin{array}{l}\text { Treated } \\
\text { Sulfo- } \\
\text { carbon }\end{array}$ & $\begin{array}{l}\text { Grafted } \\
\text { American } \\
\text { Plants }\end{array}$ \\
\hline 1883 & 60,477 & 22,136 & 47,733 & 62 & 1.8 & 85.75 \\
\hline 1884 & 58,352 & 18,688 & 47,858 & 69 & 1 & 101 \\
\hline
\end{tabular}




\begin{tabular}{|l|l|l|l|l|l|l|}
\hline 1885 & 58,203 & 18,186 & 47,066 & 67 & 1 & 287 \\
\hline 1886 & 44,753 & 15,265 & 56,518 & 78 & 2 & 604 \\
\hline 1887 & 31,893 & 11,410 & 61,149 & 92 & 22 & 1049 \\
\hline 1888 & 30,929 & 10,270 & 59,116 & 148 & 9 & 1589 \\
\hline 1889 & 28,300 & 9,724 & 62,627 & 178 & 223 & 2232 \\
\hline 1890 & 29,282 & 9055 & 63,185 & 378 & 1070 & 2599 \\
\hline 1891 & 30,682 & 8893 & 63503 & 276 & 109 & 3789 \\
\hline 1892 & 28,039 & 7294 & 66,004 & 35 & 5.5 & 5591 \\
\hline 1893 & 28,443 & 5465 & 68,083 & 25 & 1 & 5761 \\
\hline 1894 & 25,859 & 4794 & 72877 & 390 & 1 & 8007 \\
\hline 1895 & 23,156 & 5078 & 75,025 & - & - & 9583 \\
\hline 1896 & 22,987 & 4574 & 75,793 & - & - & 9867 \\
\hline 1897 & 21,280 & 5690 & 78,221 & - & - & 10,588 \\
\hline 1898 & 22,505 & 5363 & 79,550 & - & - & 13,138 \\
\hline 1899 & 21,249 & 6354 & 80,521 & - & - & 13,710 \\
\hline 1900 & 21,367 & 6340 & - & - & - & 15,027 \\
\hline 1901 & 21,672 & 5069 & - & - & - & 16,603 \\
\hline 1906 & 23,995 & 990 & - & - & - & 23045 \\
\hline 1907 & 24,900 & 650 & & & & \\
\hline
\end{tabular}




\begin{tabular}{|l|l|l|l|l|l|l|}
\hline 1908 & - & 400 & - & - & - & 24,372 \\
\hline 1909 & -- & 250 & - & - & - & 24,642 \\
\hline 1910 & 25,130 & 210 & - & - & - & 24,920 \\
\hline 1912 & 25,890 & 150 & - & - & - & 25,830 \\
\hline
\end{tabular}

Source: Société Française de Protection Contre le Phylloxera 1912:

Table 1 demonstrates how Lot's viticulturalists did little in the way of replanting or treatments prior to 1883 , even though they had already lost $1 / 4$ of their vineyards.

Furthermore, those in favor of different sulfur-based treatments had brief and ephemeral success in "interesting" people to their case. While viticulturalists had already begun working with "hybrid" plants, these totals ramped up after alternative treatments stopped. With only 150 ha of uninfected plants remaining, one can see how much more disastrous phylloxera would have been if the contingent against "hybrid" plants would have continued to remain influential. Even more shocking though, Lot would lose almost $2 / 3$ of its vineyards to phylloxera by 1912, even after much work had been done to "reconstitute" its vineyards. This partial "reconstitution" took nearly 34 years (Société Française de Protection Contre le Phylloxera 1912) from the arrival of phylloxera to the last recorded date in the above table. This reduction of vineyards would be a high-water mark for the 20th century. This catastrophic period of the ravaging and reconstitution lasted longer "wine madness" had (Baux 1982).

Yet losses and replanting were not uniform across Lot. Grapevines in certain soils, like those in oolitic limestone on the coteaux or causses, were more susceptible to 
the phylloxera aphid (Mouillefert 1904). Unfortunately, these soils furnished some of the highest quality wines in Lot, wines which had built a global reputation. Not only did phylloxera kill grapevines in these areas, they had shallow and marginal soils that could not support many American grafted plants (Rey 1908). When grafted plants could not thrive there, their value tumbled. These coteaux lands which had at the outset of phylloxera been worth 1500-2000 frs/ha, were virtually worthless after the phylloxera epidemic. Better lands lost 1000 frs in value after phylloxera, while even by 1912 land values for better agricultural land would not return to their pre-phylloxera levels (Société Française de Protection Contre le Phylloxera 1912). Here an aphid transformed land values, which would have affected property taxes returned to the state. This destructive aphid impoverished Lot and its citizens in multiple ways. While its destructive march was arrested, viticulture would never return to its former scale (Velsaco-Graciet and Rouvellac 2002). Even though a stabilized actor-network formed around the efficacy of hybrid plants, soils revolted against their survivability (Rey 1889).

The problem with focusing on these more fertile lands per Larue (1906:13) was that the "reconstitution" moved with rapidity on more fertile lands, which produced a lower quality wine. By 1906, viticulturalists had replanted the steep hillsides (coteaux) of Lot, though many of these plantings would have to be removed because of the lowquality wine they produced or because the "hybrid" plants could not thrive in such poor soils (Mouillefert 1904). Pre-phylloxera vineyards in Lot produced an average 600,000 hl of wine with a profit ranging from 15-20,000,000 francs in earnings. After reconstitution with "American" plants, the vineyards only profited 3,200,000 francs, even though 
hybrid grapevines planted in suitable soils could double the yields of older un-grafted "French" grapevines (Rey 1908).

Another major problem for Lot was that it was hit by phylloxera relatively late. Viticulturalists were also late to act. Viticulturalists in other major-producing regions had already begun "reconstituting" their vineyards and did so with rapidity. Even as the future of French wine itself seemed in doubt less than a half century before (Planchon 1875), by the early 20th century France was hit with a crisis of overproduction in wine, further dropping prices in Lot and elsewhere (Direction Départemental de l'Agriculture du Lot Service du Génie Rural des Eaux et des Forest 1969). Already by the 1930s, only 20 years after Lot had "reconstituted" its vineyards, officials would begin discussing an appellation d'origine contrôlée (AOC) to gain better status in markets and to improve sales in an increasingly competitive national market (Département du Lot 1939-7 M 63). Lot's viticulturalists gained their AOC in 1971. To fulfil AOC requirements, they had to remove many grape varietals and replant primarily Malbec grapevines. While there would be 4,300 ha planted in grapevines in AOC areas in Lot by 1991, there were only $\sim 500$ hectares of grapevines after they earned their Cahors AOC (Velasco-Graciet and Rouvellac 2003), which was only .6\% of Lot's peak area and $2 \%$ of its postphylloxera reconstituted area. Therefore, phylloxera effects are still felt in Lot.

\section{H. The Invention of Trufficulture in Lot in the Wake of Phylloxera}

Lot's newfound reliance on trufficulture was an effect of disastrous relations. Many communes on the causses like Concots would have their grapevines, their main source of income, decimated by the phylloxera aphid. Farmers would desperately need alternative revenue. Post-phylloxera, trufficulture's moment arrived in Lot (Larue 1906; 
Rey 1908). The commune of Concots had 200 ha of grapevines before phylloxera, after they were left with 3 ha. By 1880 they began to remove dead or infected grapevines and replace them with oaks. Concots would soon become one of Lot's leading truffle producers (Chauveau 1984) as well as an important truffle market (Gay and Gromas 1937). These weekly markets would regularly have two to six tonnes of truffles for sale. Buyers from many truffle houses would visit these markets and expedite these truffles around the world (Mayssonnier 2010). Some families alone would harvest 50 kilos a week, sell truffles at four or more of the different regional markets in Lot and earn enough to build a house from their truffle earnings (Chauveau 1984). Some have argued that grapevines prepared the soil for trufficulture and that no other previous 'culture' would prepare the soil as well as grapevines (Castelnau 1978; Rebière 1974)

Such results were not anomalous. Trufficulture could partially take the "place" of 'phylloxerated' grapevines on the causses in Lot (Ministère de L'agriculture 1959). It was primarily in the north of Lot on the causse de Martel that Lot's national notoriety in truffles was first garnered (Baux 1982; Larue 1906). The arrondissement of Martel had 10,660 ha of grapevines in 1852 and would only have 2,021 ha by 1902 because of the ravages from the phylloxera aphid. Before the phylloxera epidemic and the widespread practice of trufficulture, Lot's truffles were once produced "spontaneously" or 'naturally' (Gaignebet 1923). Delphon (1831) even mentions that the canton of Martel had many "natural" truffières near its pastures. People would bring pigs to pasture edges in search of such truffles. Instead of seeing them as a forest product, Delpon (1831) lists mushrooms and truffles under his section on pastures. He mentions truffles in only a few other cantons. Martel then was vital for Lot's truffle production. 
Bosredon (1887) mentions how certain communes like Martel, Cuzance and Cressensac (all in Lot's Dordogne River valley) had achieved high yields of quality truffles. The truffle transformed towns from some of the poorest to some of the richest in the département. Mouillefert (1904) argues that communes like Concots on the causses were particularly hard hit by phylloxera. Initially, "hybrid" grafted rootstock could not survive on these marginal lands. Farmers there had few choices but to plant truffle oaks on the steep hillsides that could no longer sustain grapevines. "Artificial" truffières on these 'phylloxerated' lands could produce earnings of $2000 \mathrm{fr} / \mathrm{ha}$ on marginal lands, when other crops would often only produce $200 \mathrm{fr} / \mathrm{ha}$ (Baux 1982).

In fact, it is with the tragedy of phylloxera that Meulet (1889) begins the story of truffles in Lot. In the only truffle manuals to focus exclusively on Lot, Pezet (1883) and Meulet (1889) each cite phylloxera as the catalyst in expanding Lot's truffle actornetwork. Despite the importance of the phylloxera aphid, a single human is credited for truly launching trufficulture in Lot. While Joseph Talon is the peasant from southeastern France that is often credited for "inventing" "artificial" trufficulture in all of France (De le Bellone 1888), a man with the surname of Massalave from the north of Lot emerges as a progenitor of "artificial" trufficulture there. I include here a long excerpt describing Massalave's very un-Talon-like story (Meulet 1889:3-7):

"About fifty years ago, a man of modest means, without education, but with an observational spirit, saw the truffle growing at the feet of, or nearby certain trees, while thinking with reason that this precious tuber was due to some secret of the roots or because of the shade of a nearby bush. Well, being a philosopher by instinct, he said: 'If all my land was of this nature, the same cause would produce the same effect; if one multiplied the truffle oak, then just the same, the truffle would multiply as well.' ... Our good villager soon took to practical matters. At distances of four to five meters he planted his rows of grapevines and his truffle oaks. He did not manage to get to watch them grow, as his father, with a less observing spirit and who was a slave to routine, uprooted them. It was in vain 
that this new Parmentier [a man famed for promoting the potato in France] had developed this new genre of farming methods (culture). While the one would plant, the other would uproot these trees to save his beloved grapevines. The son, however, did not lose his drive; the death of his viticulturist father allowed him to plant in the way that he wanted. Twelve years later, he harvested good truffles, just as he had dreamed, and better than anything he had seen before. Encouraged by his success, he undertook this experiment on a vast scale. He planted [acorns] in his garden and transplanted his young oaks. Four or five years later, while he could fill all his lands, he would furnish his neighbors [with trees] who did not delay in imitating him. While the reputation of this man is well known, even in faraway places we talk of his discovery, and now that, in his modest retreat, he was contented to find that revenues were by no means low, which put him in high standing. The Minister of Agriculture, whose fine palate had once no doubt tasted the perfume of this precious tuber, did not want to leave the progenitor without a reward. He himself took the initiative to have the villager present these products of his culture at the Cahors Exposition in 1881. A gold medal worth 1000 franc was given to him [Massalave]. Unfortunately, he was not able to enjoy this honor for long. With his death in 1882, he left to his two children his reputation and a substantial fortune that smelled of truffles..."

While Massalave, like Talon, was an observant and industrious peasant farmer who was made affluent by the truffle, their stories are markedly different. Talon came from France's top truffle producing département, Vaucluse, while Massalave came from its third, Lot (Chatin 1892; De le Bellone 1888; Meulet 1889). Talon made an 'accidental discovery of trufficulture. Talon was merely sowing acorns to create a future source of food for his sheep and pigs, without intending to produce truffles (De le Bellone 1888; Valserres 1874). Contrarily, Massalave was trying to replant his truffière in his vineyard. Massalave had observed the products of "natural" trufficulture and hoped to cross the "Great Divide” (Latour 1993) into “artificial” trufficulture (Meulet 1889), whereas it seems that Talon may have never intended to produce truffles at all (De le Bellone 1888).

Also, there is no other character in Talon's story until he was already successful and his cousin came to learn his secrets. No antagonist presents any obstacles for Talon (De le Bellone 1888), while Massalave needs to fight against his father who was a "slave to routine" and who would uproot his oaks. It was only his father's death that allowed 
Massalave to manage the farm as he wished. He then could exercise the thinking of a new generation. Only through perseverance would the young Massalave became a successful trufficulteur (Meulet 1889). While Massalave not only helped his neighbors create their own truffières (Meulet 1889), Talon guarded his secret and bought up their marginal lands and sowed acorns there himself (De le Bellone 1888). Here we have a more shared prosperity in Lot. Lastly, while Auguste Rousseau would win fame and awards for promoting Talon's techniques (De le Bellone 1888; Valserres 1874), Massalave himself, won an award and prize money for his truffières, potentially because he had more readily shared his practices.

Meulet (1889) takes a strongly didactic tone with his readers and tells them to be like Massalave and plant their oaks in lands that were destroyed by phylloxera. Massalave was the model to stop young people from going to cities or abroad. For Meulet (1889) and Pezet (1883) trufficulture would be Lot's post-phylloxera salvation. Few if any other crops could provide compared revenue on the land once occupied by grapevines. As important as phylloxera was in the history of trufficulture, Massalave had planted his truffières before the arrival of the phylloxera aphid, as he died in 1882 with wealth from the truffle. His truffières took twelve years to produce (Pradel 1914). If one is to take this story at face value, along with the oaks being uprooted multiple times, then it is safe to say that Massalave would have planted in the 1860s if not before (Gaignebet 1923; Meulet 1889). If we believe Chatin's (1892) and Vire's (1907) numbers for Lot's production from the 1860 s to 1880 s then one would assume an even earlier date of the diffusion of trufficulture in Lot as yields were already high, or these truffles came from 'natural' or 'spontaneous' yields as Delpon (1831) suggested. Valserres (1874) had said 
that Lot was lagging compared to other départements like Vaucluse. Therefore, these accounts suggest that once "artificial" trufficulture began in Lot, it did so quickly. With at least 50,000 hectares of suitable former vineyards (Larue 1906), the exact lands which were suitable for an aggressive, “virulent” truffle (Sourzat 2009). For Meulet (1889), many farmers either had to quickly become trufficulture or they would may have no other choice but to emigrate.

\section{Describing the "Golden Age" of Trufficulture in Lot}

While it could not fully make up for the lost revenue of wine, the truffle at the height of its production would provide Lot with 4 million francs in revenue. Rey (1889) emphasizes that as $2 / 3$ of Lot is made up of causses land, many of these lands are suitable to trufficulture. While the causses had been viticultural areas pre-phylloxera, "hybrid" grapevines could not survive on many of these calcareous lands with shallow soils, making reconstituting grapevines there difficult (Mouillefert 1904).

Rey (1889) believed that if trufficulture were properly practiced, its revenue could climb to 6 million francs. He said one only needed to combine four factors: 1. "Favorable soils" like those of the causses, 2 . The proper trees species, which are the local oaks (Quercus pubescens), 3. "A cleared surface" like those former viticultural lands, 4. "Sufficient clearing", which meant that rows should be 6 to 10 meters apart and at least $40-50 \mathrm{~cm}$ of space between branches in columns (Rey 1889). Just as Pradel (1914) and Bosredon (1887) had recommended in their truffle manuals, Rey (1889) recommended that one must remove unproductive trees as well as eventually maintain 3-4 $\mathrm{m}$ in columns. As previously discuss humans not only need to try to assembling actornetworks suitable to the Tuber melanosporum truffle, they needed to maintain these 
suitable conditions (Bosredon 1887; Pradel 1914). Meulet (1889) recognized that such replanting would be work, but also that there were few other options. De Lamberterie (1856) had recognized how difficult Lot's land was to work, under the best conditions, much less after the phylloxera epidemic (Baux 1982).

In his second study of agriculture in Lot, Rey (1908) found that truffières had "multiplied". Lot had increased its revenue from truffles by 500,000 fr/year. Prices were around 12 fr/kilo. With these prices and higher yields, crops like wheat, corn, potatoes, hay from 'natural' prairies, wine and timber provided more gross revenue than truffles. While Rey (1908) gives no definitive data on the hectares of truffières in Lot, he mentions that to earn more than trufficulture, 79,500 ha of wheat, 25,000 hectares of corn and 20,000 ha of potatoes were needed. Therefore, per hectare earnings for trufficulture were much higher than many other "cultures". With the advancements of "hybrid" grapevines in the years between the publication of the two manuals, Rey (1908) and (Bosredon 1887) both argue that one can plant truffle oaks between rows of grapevines to help offset costs. He recommends that one must work the ground superficially in the spring to create favorable soil conditions for the truffle's mycelium (Rey 1908). Rey (1908) was promoting artificial trufficulture along the lines of scholars elsewhere like Bosredon (1887) and Pradel (1914) in Lot's neighbor, Périgord.

"Artificial" trufficulture indeed worked well in Lot as Larue (1906) provides yields of 200 to 500 tonnes of truffles per year. Prices for this "precious mushroom" were profitable and demand was high. Larue (1906) also describes common practices of "artificial" trufficulture by describing that one must prune trees and plow the ground to develop a horizontal tree and root structure. Such techniques could produce 100-150 
$\mathrm{kg} / \mathrm{ha} / \mathrm{year}$. He uses average prices of $10 \mathrm{fr} / \mathrm{kilo}$ to mean that land that had become worthless in the wake of the phylloxera aphid could not produce a yearly revenue of 1000-1500 fr/ha. Others list much higher yields of 400-500 kg/ha in communes like Baladou, though Martel only had an average of $50 \mathrm{~kg} / \mathrm{ha}$ (Département du Lot 1919). Larue (1906) argued that to achieve yields of 100-150 kg/year one should use manure and phosphoric acid, though the use of fertilizers was a controversial practice in trufficulture (Chatin 1892; Pradel 1914). Larue (1906) describes how the commune of Payrac hoped to duplicate the success of Martel by rapidly planting truffières, and even hold regular truffle markets. He notes that Martel became "one of the most important truffle markets in the world", which not only attracted local people, but "foreigners" as well. Vire (1907), in his travel guide for Lot, concurs that one could not trust the official statistics of the time. He states that truffle production in Lot ascended from 46.67 tonnes in 1856, to 102.01 in 1870 , to 201.54 in 1880 , to 207.76 in 1890 to 360.00 in 1892 to 717 tonnes in 1896, which demonstrates dramatically ascending yields. Yields more than triple between the arrival of the phylloxera aphid and 1892 (Vire 1907).

As discussed by Chatin (1892), data for truffles has always been hard to ascertain. While I have listed anecdotal data above, I will now present the clearest data available for the truffle in Lot. The best records from France's Annual Agricultural Statistics were filled out by each commune's mayors, with significant gaps in data, as forms for certain communes, important truffle-producers and not, were either not sent back or lost in the intervening years. No data exists for truffle harvests for entire years (Département du Lot 1931). It seems all but impossible that there were not any truffles. For data that do exist, quantities are in quintals which is equivalent to 100 kilos. Another problem is that truffle 
data appear only by 1901, leaving many productive years without clear data, and a gap that suggests that high yields appeared without precedent as if by magic. I have included divisions of the arrondissement to compare yields between north Lot in the arrondissement of Gourdon which included the canton of Martel and the major truffle producing communes of Martel, Cressensac, Cuzance and Sarrazac, and the arrondissement of Cahors which included other major truffle-producing cantons like Concots, Limogne-en-Quercy and Lalbenque.

Table 2. Lot's Truffle Harvests 1901-1920.

\begin{tabular}{|c|c|c|c|c|}
\hline Year & Cahors (Quintals) & Gourdon & Figeac & Total \\
\hline 1901 & 1067 & 1432 & 81 & 2580 \\
\hline 1905 & 341 & 401 & 78 & 820 \\
\hline 1906 & 852 & 1750 & 80 & 2682 \\
\hline 1909 & 937.5 & 821 & 63.5 & 1822 \\
\hline 1910 & 1036 & 1804 & 42 & 2882 \\
\hline 1911 & 830 & 1767 & 32 & 4866 \\
\hline 1912 & 773 & 1732 & 144 & 2649 \\
\hline 1913 & 935 & 1542 & 65 & 2542 \\
\hline 1915 & 790 & 907 & 28 & 1725 \\
\hline 1916 & 580 & 831 & 32 & 1443 \\
\hline 1920 & 420 & 1150 & 2 & 1572 \\
\hline Sum & 8561.5 & 14317 & 647.5 & 23,346 \\
\hline Mean & 778.32 & 1285.18 & 58.86 & 2122.36 \\
\hline StDevS & 238.09 & 952.59 & 38.11 & 672.20 \\
\hline
\end{tabular}


Source: Département du Lot 1931

This table shows just how dominate the arrondissement of Gourdon was in Lot's overall truffle production as it included Martel. In 1920 the canton of Martel (Martel and its surrounding communes) produced $90 \%$ of all truffles in Lot, while on average it produced nearly twice the yearly amount of Cahors (Département du Lot 1911). While prominent truffle-producing communes like Lalbenque, Limogne and Concots were in the arrondissement of Cahors, many other communes and entire cantons like Puy-l'Évêque in the arrondissement of Cahors had replanted their grapevines and were hardly reliant on truffles for income. Its return to viticulture might be the reason that Cahors often produced less truffles than Gourdon. The arrondissement of Figeac contributed minimal quantities compared to Martel and Lot as it has little causses land. It is notable that Lot produced an average of 2122.36 quintal or 212.26 tonnes of truffles for the period, which is far less than both the figures cited by Chatin (1892) and Vire (1907). They relied instead on merchants' data, which suggests that the 'official' statistics that I use here underestimated truffle yields from the time.

I will provide here another table (Table 3) which does not have the same breakdowns in arrondissements and only has totals for Lot but does provide additional truffle totals and the harvest of non-truffle forest mushrooms in Lot. Again, each of these harvests were highly dependent on rainfall and so fluctuations in yields can offer insight into local climate variability (Bonnet 1869). Martel had a drought in 1904 and 1905 which led to rapid declines in their truffle yields (Département du Lot 1907). This table also provides earnings from both truffles and forest mushrooms, which show 
considerable annual variability. To fill in some of the gaps in the archives' data from 1920-1929 (Département du Lot 1931), I will include truffle data from Gromas and Gay (1937), which helps to cover missing years in Lot's truffle production in the government’s Annual Agriculture Statistics:

Table 3. Truffle and Forest Mushroom Production in Lot from 1900-1932.

\begin{tabular}{|c|c|c|c|c|c|c|}
\hline Year & $\begin{array}{c}\text { Quintals } \\
\text { (Truffles) }\end{array}$ & $\begin{array}{c}\text { Total } \\
\text { (Francs) }\end{array}$ & $\begin{array}{c}\text { Fr/Quintals } \\
\text { Average }\end{array}$ & $\begin{array}{c}\text { Forest } \\
\text { Qushrooms } \\
\text { Quintals }\end{array}$ & $\begin{array}{c}\text { Total } \\
\text { Francs }\end{array}$ & $\begin{array}{c}\text { Average } \\
\text { Fr/Q }\end{array}$ \\
\hline 1900 & $3,700.00$ & $2,450,000.00$ & 650.00 & - & & \\
\hline 1901 & $1,704.00$ & $1,533,600.00$ & 900.00 & - & & \\
\hline 1902 & $2,902.00$ & $2,920,000.00$ & $1,000.00$ & - & & \\
\hline 1905 & 820.00 & $984,000.00$ & $1,200.00$ & - & & \\
\hline 1906 & $2,600.00$ & $3,120,000.00$ & $1,200.00$ & - & & \\
\hline 1907 & $1,078.00$ & $1,509,200.00$ & $1,400.00$ & - & & \\
\hline 1908 & $2,683.00$ & - & - & - & & \\
\hline 1909 & $1,052.00$ & - & - & - & & \\
\hline 1910 & $2,882.00$ & - & - & - & & \\
\hline 1911 & $2,629.00$ & - & - & - & & \\
\hline 1912 & $2,749.00$ & & & - & & \\
\hline 1913 & $2,523.00$ & & & - & & \\
\hline 1915 & $1,735.00$ & & & - & & \\
\hline 1916 & $1,716.00$ & - & - & - & - & - \\
\hline 1917 & $1,516.00$ & $530,600.00$ & 350.00 & 204.00 & - & \\
\hline 1919 & 615.00 & $276,750.00$ & 450.00 & 34.00 & $10,200.00$ & 300.00 \\
\hline
\end{tabular}




\begin{tabular}{|c|c|c|c|c|c|c|}
\hline 1920 & $1,572.00$ & - & - & 398.00 & - & - \\
\hline 1921 & 695.00 & - & - & 839.00 & - & - \\
\hline 1922 & 639.00 & $2,875,500.00$ & $15,000.00$ & & & \\
\hline 1923 & 323.00 & $3,876,000.00$ & $12,000.00$ & & & \\
\hline 1924 & 693.00 & $2,772,000.00$ & $4,000.00$ & & & \\
\hline 1925 & $1,125.00$ & $3,937,500.00$ & $3,500.00$ & & & \\
\hline 1926 & 838.00 & $2,933,000.00$ & $3,500.00$ & & & \\
\hline 1927 & $1,794.00$ & $5,740,800.00$ & $3,200.00$ & & & \\
\hline 1928 & $1,794.00$ & $5,740,800.00$ & $9,000.00$ & 526.00 & $263,000.00$ & 500.00 \\
\hline 1929 & $2,595.00$ & $14,272,500.00$ & $5,500.00$ & & & \\
\hline 1932 & 981.00 & $2,943,000.00$ & $3,000.00$ & 462.00 & $184,800.00$ & 400.00 \\
\hline Total & $\mathbf{4 5 , 9 5 3 . 0 0}$ & $\mathbf{5 8 , 4 1 5 , 2 5 0 . 0 0}$ & -- & $\mathbf{2 , 4 6 3 . 0 0}$ & $\mathbf{4 5 8 , 0 0 0 . 0 0}$ & -- \\
\hline Median & $\mathbf{1 , 7 0 4 . 0 0}$ & $\mathbf{2 , 9 2 0 , 0 0 0 . 0 0}$ & $\mathbf{3 , 0 0 0 . 0 0}$ & $\mathbf{4 3 0 . 0 0}$ & $\mathbf{1 8 4 , 8 0 0 . 0 0}$ & $\mathbf{4 0 0 . 0 0}$ \\
\hline Mean & $\mathbf{1 , 7 0 1 . 9 6}$ & $\mathbf{3 , 4 3 6 , 1 9 1 . 1 8}$ & $\mathbf{3 , 8 7 3 . 5 3}$ & $\mathbf{4 1 0 . 5 0}$ & $\mathbf{1 5 2 , 6 6 6 . 6 7}$ & $\mathbf{4 0 0 . 0 0}$ \\
\hline StdevS & $\mathbf{9 0 9 . 8 7}$ & $\mathbf{3 , 1 0 2 , 5 9 1 . 7 2}$ & $\mathbf{3 , 9 9 2 . 9 9}$ & $\mathbf{2 3 9 . 7 3}$ & $\mathbf{1 1 0 , 6 4 7 . 9 4}$ & $\mathbf{2 2 1 . 4 7}$ \\
\hline
\end{tabular}

Source: Département du Lot 1931; Gay and Gromas 1937

This additional data, itself frustratingly incomplete, provides greater insight into the truffle economy in Lot. The truffle provided the department with a mean of 3.4 million francs from 1900-1932. Even as yields began to decline, prices rose steadily, though increases were partially offset by inflation. Another notable trend is how prices plummeted during World War 1 to only 3.5 fr/kilo, while rising to 32 fr/kilo ten years later. Lot lost over 1.5 million in revenue from the truffle (Département du Lot 1931) during these years of low supply and plummeting prices. Gay and Gromas (1937) argue 
that WWI created a shortage of labor in the countryside. Farmers instead focused on their main crops and either did not harvest truffles, maintain their "artificial" truffières, or both. Gaignebet (1923) argues that truffières were unmaintained during WWI, which changed soil chemistry and hurt their productivity.

We can see that prices greatly rebounded to pre-WWI levels. These had a mean price of 38.74 with a median price of $30.00 \mathrm{fr}$ and a mean yield of 178 tonnes. The mean of Lot's earnings was 3,436,191 fr/year and a median of 3,436,191.18 fr, though these amounts were highly variable as the large standard deviation suggests (Département du Lot 1931).

As forest mushrooms and truffles each had highly variable years, I wondered if they would be correlated. The same Annual Agricultural Statistics periodically listed yields for "forest mushrooms" as well as truffles. One issue is that forest mushrooms were collected throughout the entire department, while truffles came mainly from the causses. These different mushrooms may not share the same seasons and so may demand different precipitation regimes and other climatic conditions. Potentially because of these variations, a Pearson' correlation statistical test showed that they had a very weak negative correlation with each other. If one could not understand truffle yields by understanding variations in forest mushrooms, I suspected that rainfall might account for these variations.

Gay and Gromas (1937) provide records of total millimeters of rainfall and days of rainfall from the years of 1891-1909. I have taken this data and analyzed the above data for correlation between rainfall and truffle production. Unfortunately, the lack of truffle data means that only eight years had both truffle harvests and rainfall data. It was 
surprising that there was only a weak positive correlation .4139 for rainfall and truffle production and a positive correlation of .4041 for days of rainfall and truffle production. Considering the importance of rainfall for truffle production these results are surprising, though one can understand it as the data is aggregated for the entire year. Thus, one cannot know if rainfall occurred or not during the months of July-September, which it is particularly important for truffle production (Bonnet 1869).

While accessing data on truffle yields is difficult, what remains even more difficult to ascertain from these statistics is exactly how many hectares of "artificial" truffières were in Lot. If we take Larue's (1906) estimate that average production was $100-150 \mathrm{~kg} / \mathrm{ha}$ then from the above figures we could ascertain that there might have been roughly 2000 ha of highly productive truffières as yearly median production was 2009 tonnes or roughly 209,000 kilos (Département du Lot 1931).

Yet Delpon (1831) argued that much of Martel's production came not from "artificial" truffières, but rather from "natural" ones, which were located at the edge of pastures. The years that Massalave promoted trufficulture in Lot are too late to account for the high yields in Lot described by Vire in the 1860s (1907). Such observations should not be surprising as sheep and truffles shared much of the causses, especially after phylloxera killed grapevines there (Rey 1908). It would be a mistake to downplay just how important of actants grapevines and sheep could be in truffle actor-networks (Bosredon 1887; Castelnau 1978).

\section{J. The Effects of Sheep and Per Hectare Yields}

While I have discovered an overall favorable role for silvopastoralism in trufficulture, officials in Lot in 1908 did not always positively view the role of sheep in 
"artificial" truffières. In fact, they conducted an analysis of the monetary losses for trufficulteurs from sheep through surveys sent by communal officials. Most polyculture, "peasant" farmers who had a truffière also raised sheep. These officials worried that sheep might damage truffières. They then suggested that communes should have people to work as guards to keep sheep out of "artificial" truffières. While officials sent these surveys out to all communes of Lot, the most complete data came back from the canton of Martel (Le Département du Lot 1908).

Table 4. Lost Truffle Revenue from Sheep in the Canton of Martel, Lot.

\begin{tabular}{|c|c|c|c|c|c|c|}
\hline Commune & $\begin{array}{l}\text { Truffières } \\
\text { На. }\end{array}$ & $\begin{array}{l}\text { \# of land- } \\
\text { owners } \\
\text { with a new } \\
\text { truffière }\end{array}$ & $\begin{array}{l}\text { \# of } \\
\text { proprietors } \\
\text { of truffières }\end{array}$ & $\begin{array}{l}\text { Landowners } \\
\text { with both } \\
\text { truffières } \\
\text { and sheep }\end{array}$ & $\begin{array}{l}\text { Yearly } \\
\text { Losses } \\
\text { caused by } \\
\text { sheep in } \\
\text { truffières } \\
\text { (francs) }\end{array}$ & \# Guards \\
\hline Baladou & 156 & 50 & 30 & 30 & 3850 & 0 \\
\hline Cazillac & 100 & 100 & 30 & 25 & 1000 & 1 \\
\hline Cressensac & 30 & 160 & 12 & 12 & 0 & 2 \\
\hline Creysse & 4 & 8 & 4 & 0 & 0 & 2 \\
\hline Cuzance & 850 & 250 & 50 & 50 & 2500 & 0 \\
\hline Floirac & 1 & 5 & 16 & 4 & 200 & 0 \\
\hline Martel & 50 & 25 & 20 & 15 & 1500 & 1 \\
\hline Sarrazac & 300 & 200 & 150 & 25 & 50,000 & 1 \\
\hline Total & 1491 & 798 & 312 & 161 & 59,050 & 7 \\
\hline
\end{tabular}


One can better estimate per hectare yields from these numbers. The above table shows that by the early 1910s newly planted truffières were twice as common as those with established "artificial" truffières, though it is unclear if they had to be mutually exclusive. Therefore, it is difficult to extrapolate from these figures the exact amount of truffières, since a tree plantation can produce as early as four years, but often begins after ten or twelve years (Valserres 1874).

Yet if you take Martel's average production before 1910, which was 1242 quintal (124.2 tonnes) (Département du Lot 1931), then their average production would be 83 $\mathrm{kg} / \mathrm{ha}$ if one assumes that all truffle production comes from planted, "artificial" truffières. Unfortunately, Lot's agricultural statistics made no division between "artificial" and "natural" production, between truffles from planted truffières in the style of Massalave or foraged from nonplanted forests (Meulet 1889). Therefore, if we are to consider the relationship between silvopastoralism and truffle production (Delphon 1831), then yields likely averaged less than $83 \mathrm{~kg} / \mathrm{ha}$, though how much lower is all but impossible to say. What further complicates such estimates is that the arrondissement of Gourdon had 30,933 ha of forest ( $20 \%$ forested) without any details regarding the use or state of this forest and whether if it could produce truffles or not. Frequent fuelwood harvest would may have made these forests remain in open canopy conditions (Rey 1889).

If one totals all data from all communes in Lot, then one arrives at a total of 3028.3 ha producing truffières and at least 379 ha of recently planted truffières for a total of 3407 ha (Le Département du Lot 1908). If you take Lot's harvest in 1908 at 268,300 kilos, then the average truffle production per hectare is $78.75 \mathrm{~kg} / \mathrm{ha}$, which is less than the 
$83 \mathrm{~kg} / \mathrm{ha}$ in the canton of Martel. Other important truffle communes like Limogne and Lalbenque had an average production of $87 \mathrm{~kg} / \mathrm{ha}$ and $49.74 \mathrm{~kg} / \mathrm{ha}$ respectively (Département du Lot 1931; Le Département du Lot 1908). With an average truffle price of $11 \mathrm{fr} / \mathrm{kg}$ from and average yields of 78.75 , average earnings per hectare were 866.25 fr/yr. The data also says that there are 2127 owners of these truffières, so on average each person had 1.60 ha (Le Département du Lot 1908). Taking the previous calculations into account, the average trufficulteur could expect to earn $1386 \mathrm{fr} / \mathrm{year}$, which equates to 5,372.45 Euros in 2016 Euros (INSEE 2017). Such revenues are clearly approximations. Castelnau (1978) convincingly argues that many of the more ornate houses in Lot's major truffle producing communes were built during peak harvest, and likely with many earned from trufficulture and the sale of truffles.

While this sum seems rather modest, the price of the truffle used in these calculations of 11 Francs in 1908 would be only 42.64 Euros in 2016 value. At the January 24, 2017 market in Lalbenque, now Lot's biggest truffle market, there were only $22 \mathrm{~kg}$ for sale at their wholesale market with prices ranging from a not unusually high amount of 500-800 Euros/Kg (FranceAgriMer 2017). Therefore, the 2017 price has jumped 11.72 to 18.76 times the average price from 1900-1908 (INSEE 2017). If we were to take the average Lalbenque market price of 650 Euros $/ \mathrm{kg}$ and had similar yields to those cited above in the early 20th century, then the average yearly earnings would be 51,187 Euros/ha/yr. With significantly lower prices a far larger portion of $19^{\text {th }}$ century society could likely buy truffles than today (Brillat-Savarin 1825; Pradel 1914).

Trufficulture did not always produce such earnings as yearly variability suggests. Table 4 shows that sheep were not always beneficial for truffières. Commentary in the 
archives, but not reprinted in the above table, argues that frequently losses in truffle revenue did not come from sheep owned by other people, or any mistaken treatment of a truffière as an open access commons, but instead it was their own sheep that caused such damage not to truffles but to truffle trees by grazing on younger saplings. Therefore, while some communes did have guards who would try to minimize the damage that sheep could cause in a truffière, there was little sense in this document that outside guards were needed. Instead, people needed to protect their own truffières from their own sheep.

Such data present a rather positive image of trufficulture in Lot at the time. While data suggests that 1908 was a good year for truffles (Le département du Lot 1911) the only other data that has hectares of truffières but sadly not the number of trufficulteurs was taken in 1915 in the arrondissement of Gourdon. It is thus difficult to discern how widespread trufficulture was. I will include this data here to show the variability of truffle yields in different communes in Gourdon.

Table 5. Hectares of Truffières and Production in 1915 for the Arrondissement of Gourdon.

\begin{tabular}{|c|c|c|c|}
\hline Canton & Truffières (Ha) & Yields (Quintals) & $\begin{array}{c}\text { Per Hectare Yields } \\
(\mathrm{Kg})\end{array}$ \\
\hline Gourdon & 59 & 10 & 16.95 \\
\hline Gramat & 26 & 9 & 34.62 \\
\hline Labastide-Murat & 174 & 34 & 19.54 \\
\hline Martel & 903 & 690 & 76.41 \\
\hline Payrac & 50 & 13 & 26.00 \\
\hline St. Germain & 247 & 46 & 18.62 \\
\hline
\end{tabular}




\begin{tabular}{|c|c|c|c|}
\hline Salviac & 26 & 27 & 103.85 \\
\hline Souillac & 62 & 47.5 & 76.61 \\
\hline Vayrac & 10 & 30 & 300.00 \\
\hline Total & $\mathbf{1 5 5 7}$ & $\mathbf{9 0 6 . 5}$ & $\mathbf{5 8 . 2 2}$ \\
\hline Mean & $\mathbf{1 7 3 . 0 0}$ & $\mathbf{1 0 0 . 7 2}$ & $\mathbf{7 4 . 7 3}$ \\
\hline Median & $\mathbf{5 9 . 0 0}$ & $\mathbf{3 0 . 0 0}$ & $\mathbf{3 4 . 6 2}$ \\
\hline StdevS & $\mathbf{2 8 4 . 7 4}$ & $\mathbf{2 2 1 . 4 4}$ & $\mathbf{9 0 . 2 2}$ \\
\hline
\end{tabular}

Source: Le département du Lot 1915

Here we see that the hectares of truffières increased between the two tables that capture the years 1908 and 1915. Yet the year of 1915 was a bad year for truffle harvests and other harvests as well, as many farmers had left for the front. Officials from the canton of Gramat said that "in general the harvests of 1915 were much below average. Because of the lack of workers, many arable lands sit un-sowed," (Le département du Lot 1915). Farmers had already started to become soldiers and headed to the front. While the mean per hectare lead is only four kilos less than my estimates for 1908, Salviac and Vayrac's high per hectare yields skews the data. The median is only $34.62 \mathrm{~kg} / \mathrm{ha}$. Not only were yields low, but prices would drop as low as 4 to 5 francs $/ \mathrm{kg}$ during the war (Gay and Gromas 1937). Truffle production in the arrondissement would decline to 836 quintals in 1916 before rebounding to 1592 quintals in 1917 and then plummeting to 292 in 1918 (Le département du Lot 1918). Therefore 1915's production of 906 quintals was not that uncharacteristic of the time. If we were to take the mean per hectare yield of $74.73 \mathrm{~kg}$, then each hectare earned $336.29 \mathrm{fr}$. If you take the median, the total is only 
$155.76 \mathrm{fr} / \mathrm{yr}$. Either way with low yields and low prices, these totals are far away from the pre-WWI estimation of $866.25 \mathrm{fr} / \mathrm{yr} / \mathrm{ha}$.

Sporadically the archives do cite prices of various goods, which will help to understand the relative value truffles had. In 1882, when truffle prices were around 10 $\mathrm{fr} / \mathrm{kg}, 1 / 2$ kilo of bread cost $.15 \mathrm{fr}$, a half kilo of beef was $.55 \mathrm{fr}$ and a liter of table wine

cost .35 fr. With truffle prices around roughly $10 \mathrm{fr} / \mathrm{kg}$ (Chatin 1982) they were worth 18 times a kilo of beef and 29 times a liter of table wine (Le département du Lot 1882).

Top quality land for grain cost $4000 \mathrm{fr} / \mathrm{ha}$, pasture was $7000 \mathrm{fr} / \mathrm{ha}$, vineyards were $2000 \mathrm{fr} / \mathrm{ha}$ (the phylloxera epidemic had already commenced), while coppiced land was only $600 \mathrm{fr} / \mathrm{ha}$ and forested land was $1000 \mathrm{fr} / \mathrm{ha}$. Land values for second to fourth class lands dropped significantly. These prices combined with the above calculations show that a single good year's truffle earning could be enough to buy a hectare of high quality coppiced land while it could also be enough to buy a hectare of fourth class vineyards (Le département du Lot 1882). Prices like those during WWI would not have allowed or likely favored the expansion of trufficulture onto new lands.

\section{K. Truffle Markets and Questions of Provenance}

While I have cautiously cited statistics for hectares of truffières and yields both before and during WWI, exact data on individual truffle markets is that much scarcer. In only one case was I able to find records that showed a time series for specific yields for truffle markets. I found these data in an unlabeled document in the archives of the l'Ecomusée de la Truffe in Sorges, Dordogne. The handwritten and then photocopied document had records from 1912-1925 for many truffle markets in Lot, Dordogne and Corrèze, though records were often incomplete. The problem is that the archival staff 
could not confirm the provenance of the document or provide information for citation purposes. Therefore, these data should be treated with caution, but with virtually no other alternative data sources, I will provide a time series from the Limogne truffle market in Lot to demonstrate the volumes for these markets. The truffle season for all years was from late November to mid to late March.

Table 8. Limogne Truffle Market 1913-1923

\begin{tabular}{|c|c|c|c|c|}
\hline Truffle Season & $\begin{array}{c}\text { Total Quantities } \\
(\mathrm{kg})\end{array}$ & $\begin{array}{c}\text { Mean Quantity per } \\
\text { Market (kg) }\end{array}$ & $\begin{array}{c}\text { Average Price } \\
(\mathrm{fr})\end{array}$ & $\begin{array}{c}\text { Price in 2016 } \\
\text { Euros }\end{array}$ \\
\hline $1913-1914$ & 24,010 & 1715 & 7.51 & 25.21 \\
\hline $1914-1915$ & 11,200 & 1120 & 4.03 & 11.29 \\
\hline $1919-1920$ & 6,000 & 428.57 & 15.84 & 15.48 \\
\hline $1920-1921$ & 11,060 & 691.25 & 12.74 & 13.97 \\
\hline $1921-1922$ & 1,530 & 139.09 & 30.49 & 37.43 \\
\hline $1922-1923$ & 6,820 & 358.95 & 39.76 & 40.89 \\
\hline Mean & 10,130 & 742 & 18 & 24.05 \\
\hline STDEV & 7702.38 & 583.21 & 13.90 & 12.66 \\
\hline Range & 22,480 & 1575.91 & 35.73 & 29.60 \\
\hline
\end{tabular}

Source: Notebook Ecomusee de la truffe Sorges

The above table shows the overall declines in production moving through the Limogne truffle market. While data exist for each individual market, I have decided to focus on aggregated yearly totals instead of showing individual data for the ten plus markets per year. Moving from year to year, we can see a dramatic increase in prices, which rose by five times their pre-WWI levels, though when adjusted for inflation rose 
by $162 \%$. What is even more notable is that there are no data for a single market between 1916 and 1919 during WWI. It is difficult to say whether markets were not held at all as the absence of data would suggest, or if no one bothered to record the data. Either way, the complete absence of data does not bode well for the truffle. For the 1914-15 year there is rapid decline in quantities but also in price, which further confirms that demand for the truffle declined and few people harvested the truffle (Gay and Gromas 1937).

One can also see the extreme year to year variability in the truffle market, especially for the year of 1921-1922, which only had 1.5 tonnes the whole year, when single market days had more truffles during the year of 1913-1914. That year had its variabilities as the 01/23/1914 market suffered from a freeze and only 60 kilos of truffles made it to market. The week before had 1400 kilos, while the week after had 3500 kilos, as the ground likely thawed and the truffles left in the ground from the previous week were harvested. While markets began at the beginning of December and ended the beginning of March, the peak months were in January and February. Prices rose during these months as well.

This increased truffle production moving through Lot's markets such as Limogne also led to the development of a truffle commerce and conserving industry in Lot with four firms in the town of Souillac alone (Le département du Lot 1918). New actornetworks were needed to deal with such quantities. Gay and Gromas (1937) state that only 50 kilos of the above production were sold fresh, therefore Appert's conservation methods were vital in being able to ship the truffle around the world. Most of Lot's production was bought and conserved. The above records not only show sales but buyers and highlight that a few truffle-buying firms like Pebeyre, Chambon and Marrel and 
Henras, all of which are still in business, bought most of the truffle at Lot's markets. They would frequently purchase 100-300 kilos per market, and with truffle markets in Concots, Martel, Lalbenque, Limogne, Gourdon, Salviac, Cuzance, Cressensac, Cahors and many other villages in Lot, they had the opportunity to literally buy and conserve tonnes of truffles a week in Lot alone.

Mayssonnier (2010) conducted an in-depth analysis of the commercial records of one of Lot's premier truffle firms, Chambon \& Marrel which provides a detailed look into the relations that allowed Tuber melanosporum production to circulate from various sites around Europe, back to Lot and then throughout the world. Mayssonnier does not treat the truffle market as a pre-existing phenomenon, but instead emphasizes the importance of new actants in the truffle network. Beyond food conservation techniques, the most important new actant to enter Lot's truffle economy was the railroad.

The first railroad arrived in Lot in 1862 and connected the city of Brive in the département of Corrèze with Figeac, Saint-Denis-Martel, Gramat and Assier. By 1869 a railroad connected western Lot, including its principal viticultural areas and its capital Cahors, to Monsempron-Libos in the département Tarn-et-Garonne. In 1884 the former province of Quercy was reunited as the railroad pushed south to Montauban also in the département Tarn-et-Garonne. The Cahors-Capdenac railroad that was finished in 1886 connected Lot to the east, while the Cahors-Brive route further connected Lot and Corrèze. These various lines meant that Lot was finally connected to much of France via railway (Baux 1982). Such connections happened at a time when truffle production was rapidly on the rise (Chatin 1892). 
Mayssonnier (2010) emphasizes how many truffle-buying houses set up in railroad towns like Cahors and Souillac to take advantage of improved connections. Truffles could not only be shipped from principal markets in Lot, but from other départements and countries. Yet people needed to foster the connections that the railroads had made possible. For Mayssonnier (2010) the passing of universal public education in France meant that there was an increasing number of literate people who could serve as truffle buyers. Telegraph networks allowed these buyers, during their travels from Concots, Lot to Spoleto, Italy, to quickly send back prices and updates from markets so that firms could coordinate purchases from central offices. In the case of the firm Chambon \& Marrell all their truffles would be conserved in Souillac. The firm's intermediaries would also travel to Russia and the US to sell truffles.

Mayssonnier (2010) shows how a 'network' of competent truffle buyers would not only buy tonnes of truffles from Lot's markets as they did in Concots, but would also buy Italian truffles before sending them back to Lot for conservation. Despite having some of the highest truffle production in France (Chatin 1892) and many truffle firms exporting its truffles (Mayssonnier 2010), Lot's truffles remained surprisingly little known (Valserres 1874). Lot often plays second fiddle to its neighboring département to the north, Dordogne (often referred to as "Périgord") (Pradel 1914). In fact, throughout France, if not the world, the winter black truffle, Tuber melanosporum, carried the informal appellation -- the "Périgord truffle" for all truffles sold in France regardless of their actual geographic origins (Pradel 1914). Brillat-Savarin (1825), the man who coined the phrase calling the truffle the "diamond" of cuisine, mentions that the best terroirs for truffles are in Périgord, saying nothing of Lot. Pradel (1914) and Bosredon (1887), each 
from Dordogne take it for granted that their département has the best truffles. Valserres (1874) claimed that Lot was behind many of the other truffle-producing departments in terms of technique. Yet Chatin (1892) and Vire (1907) paints a different picture.

Pradel (1914) had argued that most truffles conserved or sold by Périgord firms were "exotic" truffles. Meulet (1889:25), a public-school teacher and author of a truffle manual, knew the provenance of these "exotic" truffles: "the Périgord truffle, well-known throughout Europe, is nothing more than our [Lot's] truffle harvested at perfect maturity. It is under this name that most of our harvest is expedited to our neighbor, Périgord; no one imagines that ours is better than theirs."

Looking back in the records of regional truffle markets, sales at markets like Martel or Cahors were far higher than that of Dordogne's market like Perigueux, Sarlat and Sorges. Those sold in markets in the arrondissement Gourdon, whether in Gourdon, Martel, Cressensac, Cuzance or any of the other markets very well could have traveled only a few miles, crossed the border and 'became' Périgord truffles just as Chambon \& Marrel did with Italian truffles in Lot (Mayssonnier 2010).

The story of Bordeaux wine usurping Lot's wine, while denying it a reputation, seemed to play out again, with truffle houses in Périgord earning their fame in part by circulating Lot's truffles (De Lamberterie 1874; Meulet 1889). Despite some difficulties in attaining a reputation as a top truffle terroir (Pradel 1914; Valserres 1874), Lot's trufficulteurs managed to rebound from the near devastation of their livelihoods, because of phylloxera, to replanting with truffières and becoming one of the highest truffle producers in all of France (Chatin 1892). Communes within the canton of Martel became models of rural development (Bosredon 1887; Larue 1906) because of their truffle 
production and earnings. Trufficulture turned some of Lot's poorest communes into some of its richest (Bosredon 1887). In some cases, truffle earnings would lead to families building new relatively opulent homes, while in other cases they would help buy appliances and other goods (Castelnau 1978). Truffle revenue could by no means fully replace income from wine, but at least it kept some families from emigrating from Lot (Meulet 1889). There were few other options on the causses (Rey 1904).

In this chapter I described the general agricultural conditions in Lot, its moment of prosperity during "wine madness", the rapid liquidation of that wealth after the arrival of the phylloxera aphid, the surge of trufficulture in response to phylloxera and the high yields from trufficulture at the time. I also estimate per hectare yields, discuss questions of provenance, detail the technological innovations that made truffle commerce possible and briefly describe the impacts these yields had on livelihoods in Lot. Above all, by juxtaposing the ravages of the phylloxera epidemic with the rise of trufficulture in Lot, I show how tarnished this golden age was. Trufficulture did provide income to farmers who had been nearly ruined by the phylloxera aphid, but it did not fully substitute their lost income. It was a fix; however imperfect it was.

\section{Discussion}

Returning to ANT, I have introduced a host of new actants which helped to prepare Lot for its truffle "golden age" (Chazoule 2004). These actants are so diverse that no one actant, human or nonhuman, could have ever controlled them. I have described how the end of restrictive trade policies, changing inheritance laws, raising rural and agricultural populations, deforestation and the accidental introduction of the powdery mildew fungus help create the kind of open canopy forests in which Tuber melanosporum 
thrives. With Lot's viticulture at its heights at roughly 80,000 ha, phylloxera arrived like a destroying angel. Combatting and overturning some of the effects of phylloxera would require complex actor-networks that extended from the US to France. Before the state could marshal a response, the phylloxera aphid had devastated roughly 20,000 ha of grapevines. The speed of phylloxera's spread was not matched by Lot's response. Assembling such an actor-network is time-consuming slow work. Disagreement slowed action considerably. Some assumed that they could merely drown or fight the aphid with pesticides. Other argued for hybrid plants. Lot for a time even banned the importation of American rootstock, the same rootstock that would produce the grafted or hybrid plants, which would prove immune to the aphid.

Even though Lot's viticulturalists eventually fully supported these hybrid plants, these plants did not work in the marginal soils of the causses and the coteaux. The value of these lands plummeted as they were no longer suitable for viticulture. Yet, these vines had prepared for the soil for truffle oaks. Replanting quickly commenced in the wake of phylloxera. Therefore, phylloxera inadvertently cleared as much as 50,000 acres, which could be replanted with truffle oaks. Grapevines were the most favorable 'proceeding' 'culture' for trufficulture. Massalave had shared his secret of planting and maintaining “artificial" trufficulture in Lot. Many followed his example. Yields climbed for decades. Trained dogs and pigs unearthed tonnes to supply markets spread throughout Lot.

While I have argued that these truffles likely crossed the border into Dordogne to 'become' "Périgord truffles", Lot's trufficulteurs could supply tonnes of truffles to markets spread throughout Lot. Yet its merchants were not content with only selling truffles in a local market. Advancements in food conservation networks, skilled buyers, 
telegraph communication and railroad tracks would help Lot's truffles go global. Without such networks the highly perishable truffle needed to be consumed roughly in two weeks. Conserved it could last months if not years. It could travel.

Therefore, not only did new promoters of the new techniques of trufficulture like Massalave in Lot emerge, the phylloxera aphid had made its practice that much more necessary. New actants made the truffle's circulation that much smoother. All prognosis would have seemed to indicate that truffle production in Lot would continue to rise.

Yet, in the next chapter, I will describe how this actor-network that produced the "golden age" of the truffle (Chazoule 2004) would be short-lived. The high numbers of farms and rural population densities would decrease. Lands that had been ripe for trufficulture post-phylloxera would become reforested and less suitable for trufficulture. WWI would bring death and destruction. The state would focus on changing polyculture to monocultural systems. They would become so disinterested in truffle production that they would cease to collect data to track it yields. Production would decline for decades to the point that some worried that Tuber melanosporum could disappear from Lot altogether (Champagnac 2000). As farmers rapidly exited their profession, a département wide forest resurgence overtook Lot after World War II. The canopy of open canopy, intensively worked landscapes on the causses that had fostered truffle production became overgrown and underworked. The legacy of these large-scale reforestation would trouble all efforts to restore trufficulture in the decades that come. 
Chapter 4: The End of the Lot's Truffle Golden Age: Economic Competition, Agricultural Abandonment, Rural Exodus and Forest Resurgence.

\section{A. Introduction}

In this chapter I show that by the 1930s truffle yields were beginning to decline, a decline that would not be arrested until the 1990s. Through archival research, I methodically describe the crisis that faced not only trufficulture but agriculture in general in Lot. Lot's farmers faced unprecedented competition from farmers around the world. The predominance of small and under-mechanized farmers left Lot's agriculture incredibly vulnerable. Once agricultural abandonment started, it was difficult to arrest. While many farms were abandoned, Lot also began to rapidly lose its overall population. The phylloxera epidemic and World War 1 were major drivers of depopulation, while Lot's population would not begin to recover until the 1960s. As Lot lost both its farmers and general population, thousands of hectares of agriculture land transformed into forest. With little silvopastoralism or timber harvesting, forest canopies continued to close. Such closed canopy forests no longer produced truffles. I tracked growing economic competition, agricultural abandonment and the rural exodus through archival research. I also examined forest resurgences through archival data; my classifications of historic aerial images were indispensable for demonstrating land cover changes.

Such developments, each themselves a complex actor-network, show how fragile of an actor-network sustained Lot's truffle "golden age" (Chazoule 2004). Callon (1984) discusses how important actants ability to interest one another is. The truffle failed to interest other actants. Meulet (1889) would produce the last major work on the truffle in Lot for nearly 100 years. The government would cease to keep regular statistics of truffle 
production. Even by WWI some did possibly irrevocable damage to their truffières by ceasing to maintain them (Gaignebet 1923). As my data would show, nearly everything from farming population to overall population to hectares under cultivation plummeted. Only forest cover increased, but not from the replanting of truffières as after the phylloxera epidemic, but instead forests that conquered abandoned agricultural land. Such forest would not long support truffles.

\section{B. The Beginning of the End of Lot's High Truffle Production}

From 1925 to 1932 Lot's trufficulteurs produced on average 152 tonnes of truffles, while prices had risen to an average of $46.17 \mathrm{fr} / \mathrm{kl}$. Average yearly total earnings were 5.93 million francs (Département du Lot 1931; Gay and Gromas 1937). Yet if we look back to the six years between 1900 and 1907 (data for 1903 are missing), average yields were much higher 213.40 tonnes, average prices were $10.58 \mathrm{fr} / \mathrm{kl}$, average yearly earnings were 2.09 million francs. Taking inflation into account, average earnings for the first period would be equal to $8,101,318$ in 2016 Euros while the later period would be only 4,981,572.68 in 2016 Euros (INSEE 2017). Here we see that inflation had cut into these apparent increases in prices. If these calculations are accurate, then the trufficulteur was not making significant more money per kilo of truffles even as prices appeared to rise. Lot appeared to be quickly losing truffle revenue.

Looking at France in 1904 the nation's trufficulteurs produced 1029.90 tonnes of truffles at $8.43 \mathrm{fr} / \mathrm{kg}$ with earnings of 8.63 million francs, whereas in 1942 France produced only 227.3 tonnes at $450.03 \mathrm{fr} / \mathrm{kg}$ with earnings of 105.95 million francs (Castelnau 1978). Yet when one accounts for inflation these 1904 earnings are equivalent to $33,457,671.24$ in 2016 Euros, while the 1942 earnings would be 30,000,963.65 Euros. 
These values show how prices increases could only partially offset declines in yields. Yet even these comparatively 'high' prices in 1942 would only be 142 Euros/kilo in today's currency values, while 1904 prices were only $32.68 \mathrm{~kg} / \mathrm{fr}$ (INSEE 2017) Truffle prices in 2015-2016 at Lot's premier truffle market in Lalbenque would commonly range from 500-700 Euros/kg (Syndicat des trufficulteurs de Lalbenque 2016) in an era when average yearly truffle yields in Lot were only 1-3 tonnes (Sourzat 2009). Therefore, even in years with 3 tonnes of production Lot would make 1.5 million Euros from truffle sales, which would be roughly 1/30 the earnings of 1904 or even 1942 . Vastly inflated prices could not make up entirely for poor current yields. The truffle, which seemed to be democratizing during the $19^{\text {th }}$ century (Brillat-Savarin 1825; Chatin 1892) would eventually became known as one of the highest price foods in the world (CBS 2012).

With these calculations in mind, the following graph will reinforce the direction in which truffle production in the arrondissement of Gourdon was heading. Gourdan had long Lot's historic center of truffle production (Delpon 1831). The market in the town of Martel was said to be one of the best in the world, attracting tourists from all over (Larue 1906). In response to this local production, truffle buying farms moved to the area (Mayssonnnier 2010). Castelnau (1978) argues that declines were the most brutal in and around Martel. These declines, once begun, were difficult to arrest. These declines are made stronger by gaps in data because of non-returned or incomplete forms. As there is always dramatic year to year variations based on meteorological phenomenon, I have included a trend line to highlight just how dramatic declines were:

Figure 1. Truffle Production in the Arrondissement of Gourdon 


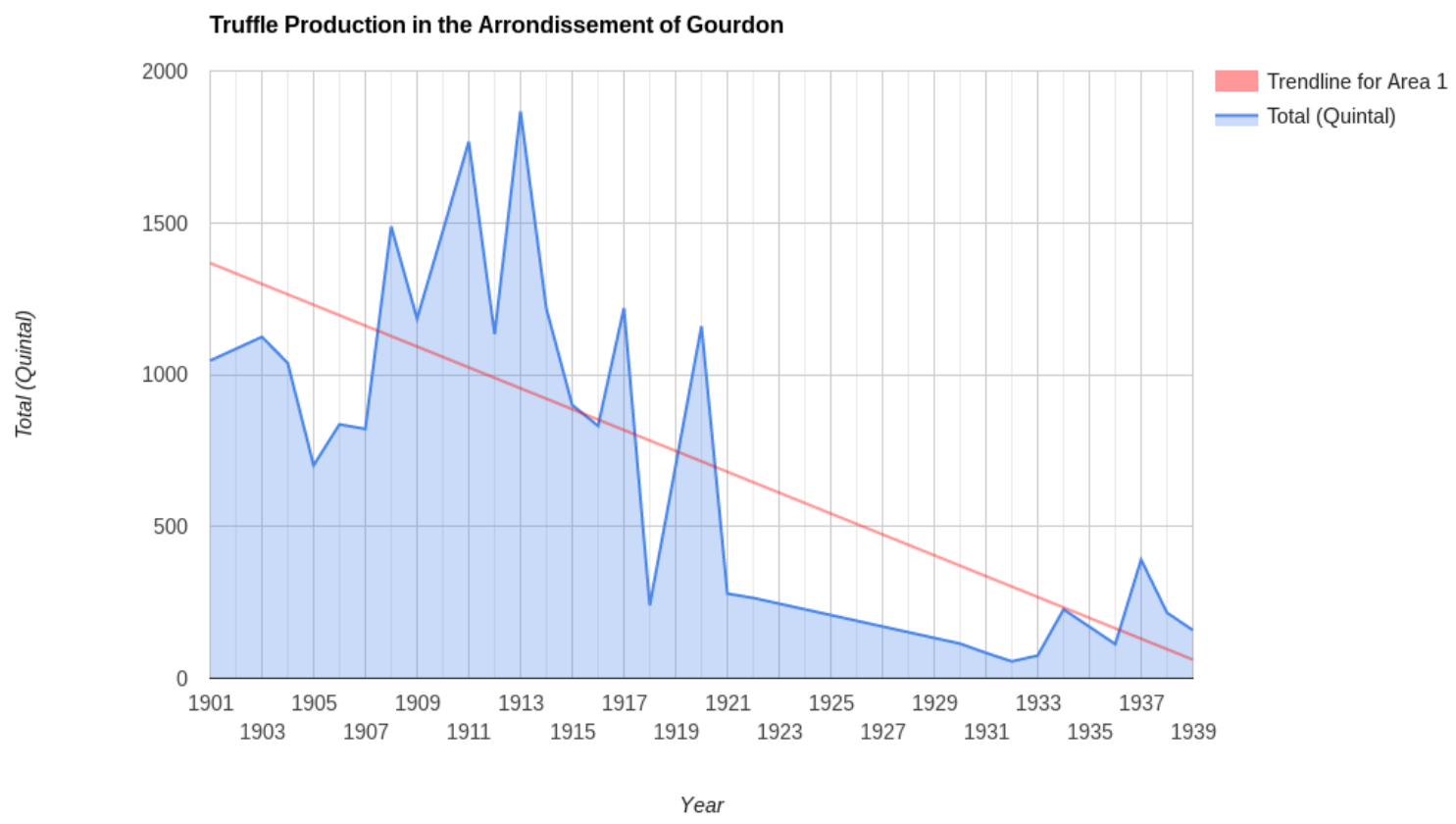

Source: Le département du Lot 1939; Larue 1906

Figure 1 shows trends of a seemingly irrevocable decline in truffle production for the arrondissement that once drove production in Lot. I have shown above that rises in prices could not offset declines in harvests. One could imagine that if an individual trufficulture maintained yields during this period that trufficulture would have remained profitable, though for those who did have declining yields, rising prices were likely not sufficiently interesting.

Another clear illustration of these declines is that there was a bi-weekly market in Martel that attracted tourists from around the world (Larue 1906) and weekly markets in other towns in the arrondissement of Gourdon. Yet today, the arrondissement of Gourdon has only one truffle market a month. Gone are the markets in Cahors, which was one of the most important in France (De le Bellone 1888) as well as the one in Concots that once sold two to six tonnes of truffles in good weeks (Mayssonnier 2010). 
Therefore, markets themselves, public places of exchange, could not continue with such a paucity of truffles. Only Lalbenque and Limogne today have weekly truffle markets, with Lalbenque being much larger. In the last five years, the greatest quantity sold at a single market in Lalbenque was $204 \mathrm{~kg}$ on 01/13/2015, while prices dipped that day to only 240-500 Euros for the bulk market, far higher than prices 80 years earlier when adjusted for inflation (INSEE 2017; Syndicat des trufficulteurs de Lalbenque 2016). With prices like these the truffle ceased to be a food of the middle class (Pradel 1914) and have taken on the reputation of a "luxury" item (CBS News 2012).

The most frustrating and yet telling aspect of tracing the truffle's decline in Lot is the lack of systematic data to track it. One of the reasons for the declines shown in Figure 1 is that certain cantons, including the truffle-producing powerhouse of Martel would sometimes not provide data. When one relies on this data, its material absence is just as good as an absence of truffles. More problematically, the Departmental Archives of Lot do not have systematic holdings for Annual Agricultural Statistics after 1939. As this was my main data source for truffle production, I can only rely on reports on other subjects mentioning truffles, as officials dedicate less direct focus on the truffle.

Data hereafter is sporadic. Documents no longer include a space for truffle yields. A report on the state of agriculture in Lot cited 150 tonnes of truffles in 1959 (Ministère de L’agriculture 1959). Another report cites 25 tonnes for 1970 (Ministère de L'agriculture 1973). By 1950s one report estimated only $5 \mathrm{~kg} / \mathrm{ha}$ for its economic calculations on the viability of trufficulture as a tool for reforestation, though did not list individual yields (Comité départemental de production et d'Equipment agricoles: procèsverbaux des séances 1952). Another report listed earnings for Lot from truffles in 1962 of 
2,200,000 NF (new francs) or 3,222,971.31 in 2016 Euros (INSEE 2017), which is comparable to earnings from times of higher production.

This report further recommends the removal of grapevines in favor of trufficulture on marginal lands. They recommend the following practices: "1. Establishing truffières on suitable soils, which will be carefully maintained with proper techniques after creating the plantation accordingly; 2. Utilizing oak saplings produced in nurseries on the causses, while at the same time continuing attempts to "infect" acorns with the truffle mycelium; 3. Distributing at cost oak saplings from controlled nurseries with the purpose of creating truffières; 4. Creating pilots of truffières and nurseries all from acorns "infected" with the truffle's mycelium." Here we can see an ambitious plan to "relaunch" trufficulture, including the free distribution of saplings (Comité départemental de production et d'Equipment agricoles: procès-verbaux des séances 1952). While scientists could "infect" saplings with truffle spores by the early 1970s (Rebière 1974), there is no record that Lot gave away plants on any mass scale, though the report does show trufficulture continued to be considered as a money maker on the causses.

Of all the scattered data sources on truffle harvests, The Chambre de Commerce (1994) is the most complete. They estimate the following average truffle harvests for different periods: 1885-1900: 300 tonnes, 1900-1915: 250 tonnes, 1915-1940: 100 tonnes, 1940-1960: 50 tonnes, 1960-1975: 20 tonnes, 1975-1990: 5 tonnes. Sourzat (2009) cites variable yields of 1-3 tonnes today.

Keeping the ideas of actor-networks in mind, I will now describe how the truffle network was transformed and in turn transformed Lot. While a series of almost revolutionary events led to spikes in truffle production, equally profound changes would 
drive its declines. Vital actants would leave while other rather nefarious actants would emerge to upset this actor-network. Trufficulteur, which had helped financially save famers in the wake of phylloxera (Meulet 1889), seemed to have little power to stop the ongoing rural exodus and agricultural abandonment. Yet as farmers left and forests increased trufficulture would become more difficult to practice (Castelnau 1978).

\section{B. Rural Exodus}

While Baux (1982) called the phylloxera epidemic the most "dramatic" moment in Lot's recent history, the rural exodus was arguably far more damaging, if less sudden. A series of brutal agricultural crises would unsettle a population that was $88.8 \%$ rural in 1846, 85\% rural in 1911 and still $79.2 \%$ rural by 1946 . Therefore, Lot did not offer significant alternative ‘urban’ opportunities (Chambre de Commerce 1994). While Lot produced 1/139 of France's agricultural revenue, it produced only 1/1000 of its industrial revenue. When a series of agricultural crises arrived there, Lot's population was particularly exposed as it lacked industry. While truffles were not subjected to severe competition, many of Lot's other crops were. Unable to compete or recover from phylloxera, many people would leave Lot (Meulet 1889).

Rey (1889) wrote urgently of the rural exodus in Lot: "Each day our countryside empties; the population diminishes rapidly, and what is worse, it is that the deplorable state of things is not only the exodus of inhabitants but as well the inferiority of births compared to deaths... as well certain people search elsewhere an easier and more assured life and go to major cities or far-away colonies in search of their fortune." Nineteen years later Rey (1908) wrote about what the grave consequences of this still ongoing rural exodus were for Lot: "Our département is not only more and more lacking men, but also 
in money. The value of land diminishes by a considerable proportion, and it is certain that it will not find buyers, even at paltry prices. As the emptiness increases every day in the countryside, many lands are left in fallows, others are completely abandoned. With each person that leaves their village, a source of tax revenue is lost for France." He argued that the rural exodus in a place like Lot was an issue of national political importance.

As Rey (1908) illustrates, the loss of Lot's inhabitants and particularly its farmers, had profound impacts on state revenue, landscapes and land values. It reverberated through many different actor-networks. De Lamberterie (1874) said that their land, their farm was the only source of revenue for many in Lot. That their farms were growing increasingly less valuable was worrisome. There appeared to be limited options for many areas of Lot outside its fertile valleys. Instead of thinking of the short term, De Lamberterie (1874) cautioned that if considerable work was not undertaken to reverse agricultural trends in Lot the "misery" of the present generation would not be overcome. Many had already emigrated (Meulet 1889). Many more would leave (Castelnau 1978). The following graph shows just how enduring this exodus was for Lot: Figure 2. Population Trends in Lot from 1790-2013. 


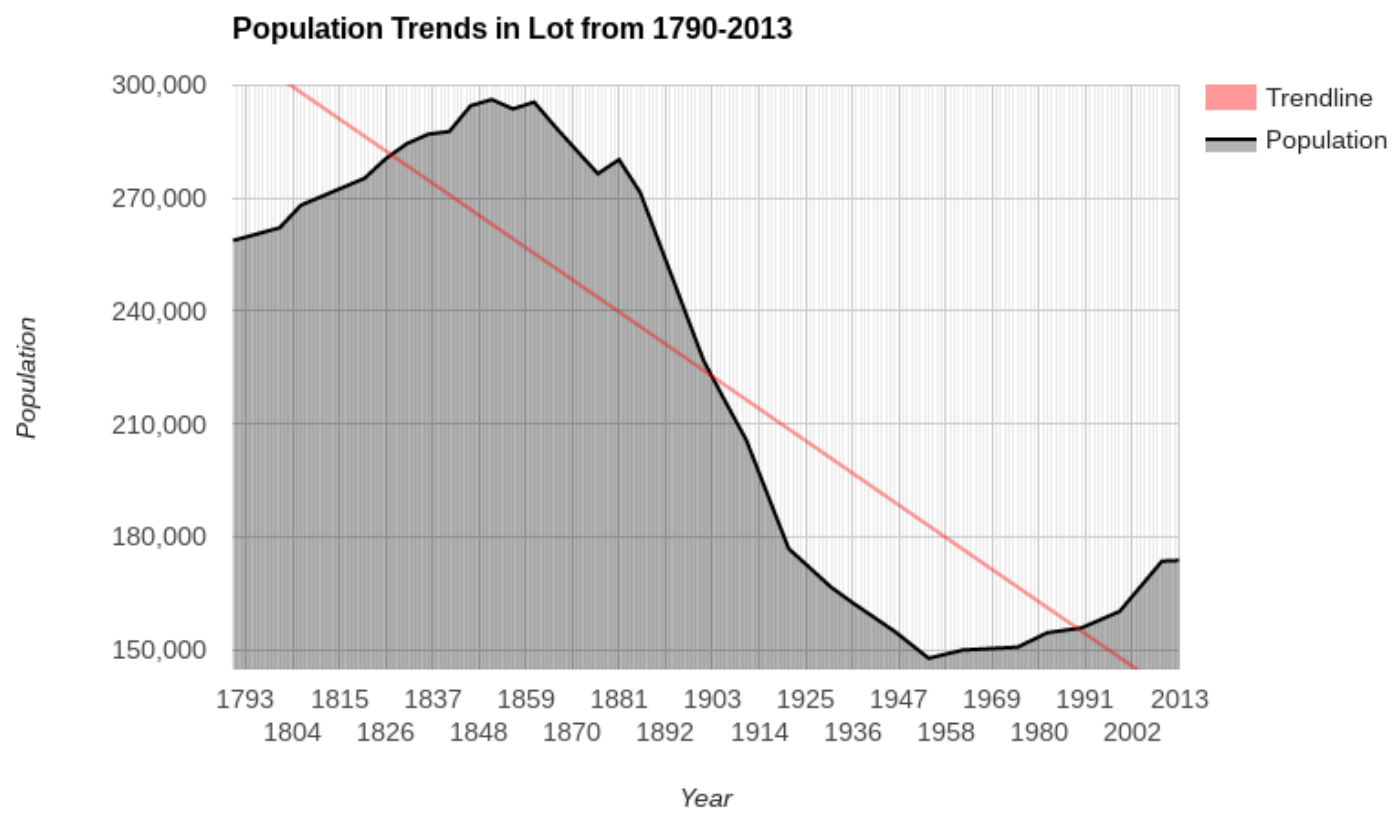

Source: Toujas-Pinede 1994; Ministère d'Etat, Ministère de L’intérieur 1975; INSEE $2017 \mathrm{a}$

Lot plummeted from a peak population of 295,542 in 1861 to a low of 147,754 in 1954, a drop of $49.84 \%$. From 1881 to 1954 , its population declined in every single census. Between 1886 and 1891 alone its population dropped by $16.50 \%$, during the height of the phylloxera crisis. Only by 1954 would its population rebound and continue with modest growth to today, though many of these arrivals would be second-home owners or retirees and not necessarily active farmers (Mergoil 1978; Benson 2014).

\section{Lot's Agricultural Crisis}

Before Lot's citizens would leave on trains and boats to make a living elsewhere (Toujas-Pinede 1990) many scholars had regretted Lot's lack of connectivity (Delphon 1831; De Lamberterie 1854). Bad roads and a reliance on the Lot river as a commercial network limited its potential to export goods (Larue 1906; De Lamberterie 1874). Yet it 
would be increasing connections and not isolation that would prove most damaging for its agricultural population and economy (De Lamberterie 1874).

One such connection, the arrival of the phylloxera aphid from America (Planchon 1875) became a major cause of this rural depopulation (Meulet 1889). The major truffleproducing commune of Concots, phylloxera had "turned upside down an insular community, many of whom emigrated indefinitely" (Chauveau 1996). During the phylloxera crisis, Rey (1889) wondered if Lot would be "vanquished" by the aphid or if they would be able to "victoriously resist" it.

As phylloxera hit the grapevines on the coteaux particularly hard and replanting came at great efforts with low yields, agriculture moved to less steep hillsides and valley bottoms, land which was scarce in many communes (Gay and Gromas 1937; Mergoil 1978). Emigration was particularly high in these communes with predominantly steep land as little else other than truffles could be produced there as grapevines would not be replanted (Baux 1982; Rey 1908).

During the period of 1876-1912, the time in which phylloxera arrived in Lot until grapevines were "reconstituted" by 1912, Lot lost 34\% of its population (Société Française de Protection Contre le Phylloxera 1912). Even with the "reconstitution" of Lot's vineyards, more rapid and comprehensive reconstitutions in other high-producing viticultural regions drove prices down in Lot (Direction Départemental de l'Agriculture du Lot Service du Génie Rural des Eaux et des Forest 1969). The above graph shows that the reconstitution of Lot's vineyards did not reserve ongoing trends of population decline. In a sad twist of irony, in leaving, Lot's citizens would follow the historic passage of their wine to Bordeaux before they themselves boarded ocean liners that left bound for the 
Americas. A small industry even emerged of promoters posting flyers and trying to draw people away from phylloxera-ravaged areas with promises of wealth in the Americas (Toujas-Pinede 1990). In the third edition of his studies on Lot De Lamberterie (1880) mourns that things had become "worrisome". He estimates that 20,000 of Lot's citizens left for the Americas post-phylloxera. Hectares under grapevines would remain relatively stable until 1952 at 19,470 ha. A brutal freeze in 1955-1956 would kill thousands of hectares of grapevines. By 1970 Lot only had 8000 ha of grapevines, which would reduce to 5,500 ha by 1990 (Chambre de Commerce 1994). Hectares under grapevines would increase to 5850 ha in 1992 (Ministère de l'agriculture et de la foret 1992) and 5710 ha in 2002 (Ministère de l'agriculture et de la foret 2002). By the 1990s most grapes would be grown in the Cahors appellation d'origine contrôlée (AOC) area. Most truffle-producing communes were not included in the AOC. These changes meant that the historic link between truffles and wine had largely been severed in Lot. Communes now focus either on viticultural or trufficulture as no major truffle-producing commune is currently located within the delimited zone of Cahors AOC.

While I previously discussed the phylloxera epidemic, another less dramatic crisis rocked Lot starting in the mid-1800s (Pinede-Toujas 1990). Rapid mechanization had rapidly increased wheat yields in the Paris Basin as well as in the United States. Yields in such flat and fertile areas were double Lot's per hectare wheat production (Lamberterie 1880). Lot would only reach similar average yields decades later, after its area of wheat cultivation had drastically shrank (Ministère de l'agriculture et de la foret 2002). This outside grain arrived in Lot at prices at which local farmers could not compete (Mergoil 1978), even though Lot had a reputation for producing quality wheat (Lamberterie 1874). 
Rey (1889) argued that if you examined all investments and earnings that farmers in Lot were growing wheat at a net loss. Lamberterie (1880) predicted that decreasing shipping costs would only make these imports that much more competitive against French wheat. Lot's farmers continued to grow wheat, but mainly for "subsistence." Lamberterie (1874) concurred that Lot had 23,000 hectares of wheat that did not produce enough revenue to cover costs. The surface planted in all cereals would reduce from 144,586 ha to only 79,622 by 1929 . Over the same period the surface cultivated in wheat would be more than cut in half (Gay and Gromas 1937). By 1953, Lot only had 33,010 ha of wheat. By 1970 Lot would only be producing .14\% of all wheat in France (Direction Départementale de L'Agriculture du Lot 1971). Wheat had long been one of Lot's principal sources of revenue and source of subsistence (Delpon 1831). Like Lot's population, wheat was in steady decline (Gay and Gromas 1929; Direction Départementale de L'Agriculture du Lot 1954).

Similarly, Lot had once been an important producer of wool, which it had exported. Cheaper imports from Australia and Argentina all but ended wool production in Lot (Baux 1982; Mergoil 1978). Without revenue from wool, sheep were raised on the causses only for their meat (Parc Naturel Régional des Causses du Quercy 2003). The causses are par excellence for raising sheep was the causses where extensive "natural" prairies existed (De Lamberterie 1854; Rey 1889). Again, the causses also held the land most suitable to truffles (Rey 1908). While sheep and truffles would come into conflict from time to time (Le Département du Lot 1908) a positive link between the two is longstanding (Delpon 1831; Larue 1906). Still, both silvopastoralism and trufficulture were each harmed by frequent drought on the causses (Rey 1908), while the agricultural crisis 
wrought lasting changes to how sheep were raised. These changes would prove damaging as well for trufficulture's actor-network.

The rural exodus removed farmers from the causses, while remaining farmers would swap extensive silvopastoralism for more intensive methods that utilized planted pastures under agricultural 'modernization' directives. In 1825, Lot had 260,000 sheep. By 1901 there were 477,073 sheep. This number would drop to 168,284 by 1938 though would rise to 420,000 by 1984 . This last figured was made possible by planted, intensive pastures. Meanwhile, the cultivation of arable land reached a peak in 1840 at 227,980 ha. In 1952 there were only 97,400 ha cultivated as arable land. Conversely, areas permanently cultivated in grass would rise from 19,754 ha in 1840 to 90,100 ha and increase to 105,000 ha by 1990 (Chambre de Commerce of Lot 1994).

Extensive silvopastoralism was increasingly giving way to intensive methods on created pastures (De Lamberterie 1874). These abandoned causses lands were overtaken by bushes and shrubs as silvopastoralism ceased to keep the area open. Not only had grazing sheep controlled such growth, shepherds pruned tree branches to feed to sheep and removed trees for fuelwood (Direction Départemental de l'Agriculture du Lot Service du Génie Rural des Eaux et des Forest 1969). By the 1960s, government officials worried if the causses would become impenetrable scrubland (Le Département du Lot 1962). Areas of the Causses de Gramat were facing such strong emigration that they were approaching the definitions of population “desertification”. Once extensively worked lands were turning into 'deserts'. Monuments of a kind were left behind as the causses land was covered with stone walls which showed how readily available labor had 
subdivided the land before the exodus (Direction Départemental de l'Agriculture du Lot Service du Génie Rural des Eaux et des Forest 1969).

Developments from the phylloxera epidemic, to increased competition in grain and wool prices would drain Lot of its agricultural population. In 1851, Lot had100,586 farm owners. Agriculture would employ a total of 158,633 people. Comparatively industry and commerce would employ only 16,058 people, while 7,077 worked in "liberal professions". In 1851, at the peak of Lot's population, the communes of Gourdon had 1681 farms, Martel had 1112, Lalbenque had 1104 farms and Limogne had 439 (Le Département du Lot 1851). By 1886, the number of farms had reduced to 84,176 (Le département du Lot 1886). Data collected by the Chambre de Commerce Lot (1994) continues these worrisome trends. By 1892 there were 80,896 farms (exploitations), which continued to decrease to 34,922 by $1929,22,712$ by $1942,20,811$ by $1955,14,107$ be 1970, 9728 by 1988. At the same time, average farm size increased from 3.7 ha in 1892 to 9.2 by 1942 and 21.6 ha by 1988 . Similar trends continued as Lot had only 9097 farms in 1992 (Ministère de L'agriculture 1992) and only 6963 farms in 2000.

Predictions suggested that the number of farms in Lot would drop to 5110 by 2011. Even with this plummeting number of farms, Lot still had $12.4 \%$ of its population on farms compared to the regional average of 7.1\% (Ministère de L'agriculture 2002). It remained 'agrarian' but with a massive loss of farms and farmers.

What is even more troubling than the simultaneous declines of Lot's agriculture and overall population is how they fed off each other. Farm labor grew increasingly scarce which presented major problems for large projects like the "reconstitution" of Lot's vineyards. Salaries for day-laborers would double between 1852-1882. In 1859 a 
day laborer was only paid 2 francs if unfed while a liter of table wine was .25 francs.

Such labor had been available for massive planting in the wake of the powdery mildew epidemic but would not be there for long. Sharecroppers or renters had cleared much of

the land on the coteaux that was devastated by phylloxera (Baynac 1971). In the wake of phylloxera, allied industries like barrel-making were hurt as well (Hermet 2000). These tenants and crafts people would often be the first to immigrate as they were not tied to their land (Toujas-Penede 1954). With rising labor costs Lot's vineyards moved off the coteaux onto the flat plains, which produced far more grapes per hectare but they made a more mediocre wine (Hermet 2000). Some ripped out their vines and started planting cereals, though these harvests were undercut by imports (Baynac 1971). Even farmers using only family labor to grow grain were doing so at a loss. Therefore, revenues from wine and wheat were falling. Farmers lacked the revenue to continue hiring laborers. As people were leaving Lot, labor costs only increased (Baynac 1971). Worker availability would never return to previous levels.

\section{World War 1 Casualties and Birthrates}

It was not only cheap imports, viticultural crises and emigration that would drive Lot's population declines. War had a further impact as France and its allies called on its farmers to head to the trenches. The number of men mobilized for WWI from Lot was 33,200 , which was $16.20 \%$ of its total population and $65 \%$ of its agricultural workers. Officials in Lot would even write asking that the national government send men to harvest its crops and work its fields as laborers had grown scarce because of rural exodus and the war (Le Département du Lot 1918). With such a large proportion of the population of Lot fighting the war, its family farms would pay heavy costs. The death 
rate would exceed the birthrate from $1914-1919$ by 10,510 people. From 1911-1921, Lot's population would drop by $14.04 \%$ as shown in in Figure 1 . The only period that had higher emigration was the height of the phylloxera epidemic.

Data suggest that the truffle went largely unharvested during WWI as yields that had often reached over 200 tonnes dropped to 61.5-152 tonnes per year (Le Département du Lot 1931). Though a bad drought further hurt harvests, the arrondissement of Gourdon, the major truffle producing region in Lot, only produced 24 tonnes of truffles in 1918. Worse than these massive decline yields, prices drastically lowered. Prices during the period dropped at the Limogne market to only 7.51 in $1913-1914$ and $4.5 \mathrm{fr} / \mathrm{kl}$ in 1914-1915, while they rose to $12.74 \mathrm{fr} / \mathrm{kg}$ in during the $1920-1921$ season and $30.49 \mathrm{fr} / \mathrm{kg}$ during the 1920-1921 season. The French average price was 9.90 in 1913-1914, 5.79 $\mathrm{fr} / \mathrm{kg}$ in 1914-1915, while prices would rise to $17.36 \mathrm{fr} / \mathrm{kg}$ in $1920-1921$ and $24.31 \mathrm{fr} / \mathrm{kg}$ in 1920-1921 (Castelnau 1978).

Such a dip in prices during WWI combined with labor shortages made some neglect their truffières (Gay and Gromas 1937). Writing soon after the end of WWI, Gaignebet (1923:662) repeats the claims of local people that this lack of maintenance greatly impacted the truffières in the canton of Martel: "as trees were not taken care of during the war, they depreciated. Others say that toxins now prevent the growth of truffle mycelium. Others repeat that the soil is exhausted and nothing is known about how to restore its fertility. This culture is completely empirical and many think that the big producers owe their success to secret practices that they never wanted to divulge." Trufficulture was already on the decline in the canton of Martel by WWI, while declines 
would worsen (Castelnau 1978). Bye (2000) argues that many 'secrets' of trufficulture were lost with these soldiers.

The fighting killed and maimed a population that was predominantly young and male. One right-wing populist at the time argued that peasants had had paid a "blood tax" for France (Paxton 1997). Losses for centers of truffle production like Martel and Lalbenque were staggering. Martel's population would decline by 120 people from 1911 1921. The names on Lalbenque's war memorial, engraved on the same limestone used to build the houses in that charming village, tell a chilling story. In 1914, it would lose 15 people to the war, 18 people in 1915, 11 in 1916, four in 1917, nine in 1918, seven in 1919 and two in 1920, for a total of 66 residents.

Lalbenque would lose 322 people from 1911-1921. Though its war monument does not list casualties by years, it lists the names alphabetically, showing that 66 of its citizens died in the war. The inscription alone on the statue tells how traumatic this event was for these villages as it was dedicated "To the Glorious Memories of the Infants Who Died for France 1914-1918". Throughout Lot, an estimated 8000 died in WWI (Souperbie 2014). In total, Lot would lose 28,000 people during the period of 1911-1921. From the above figures 8000 of the 10,000 dead would be soldiers in WWI. Declining birthrate would be more impactful.

The absence of the fighting population had other negative demographic effects. Figure 3 shows just how 'natural' population declines contributed as deaths greatly exceeded births. Therefore, there was an 'internal' decrease in Lot's population that would exacerbate trends caused by emigration. Just as with numbers of farms and truffle production, trends tracked swiftly downward. 
Figure 3. Births vs. Deaths in Lot from 1846-1923.

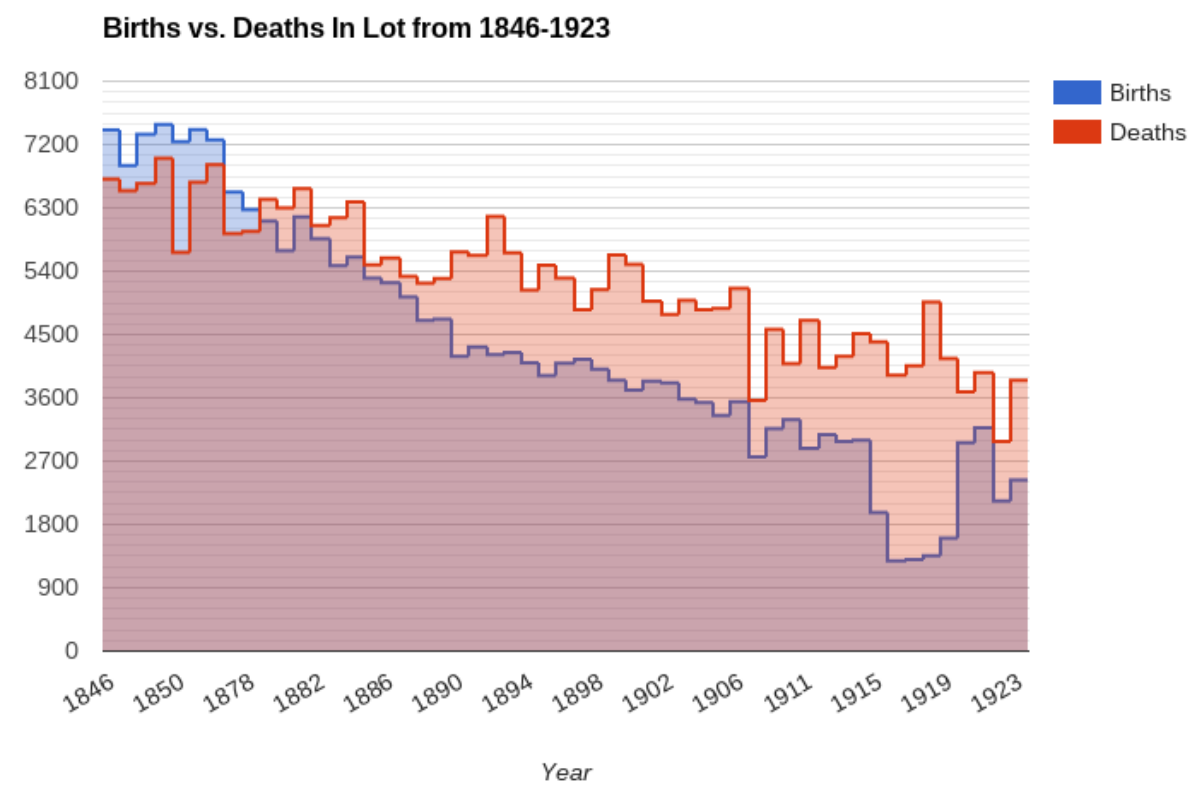

\section{E. Reforestation}

The outcomes of the war combined with general agricultural and population change were revolutionary in Lot. One major outcome that was particularly pernicious for the truffle was that dense forest cover came to dominate the land once planted as truffières on the coteaux and causses lands (Castelnau 1978). Forests began to cover Lot at unprecedented rates. This reforestation spread both because of the rural exodus and agricultural abandonment. As previously described, the areas cultivated as arable land primarily in cereals plummeted as did Lot's hectares planted in grapevines. The only land use that increased was the creation of additional pasture land while silvopastoral practices were abandoned on the causses.

Again, as the causses and truffle-producing commune of Limogne would have 439 farms in 1851 they would have only 23 farms by the mid-1900s. By the end of this 
transition Lot would have twice as much forest as it would hectares in annual agriculture (Le Centre de Gestion et D’Economie Rurale du Lot 1962). Delphon (1831) had estimated that Lot had 98,146 ha of forest or was $18 \%$ forested. By 1910 Lot would see a modest increase with 101,825 with reforestation accelerating to 115,235 or $22 \%$ by 1931 (Le Département du Lot 1931) The Chamber of Commerce and Industry (1994) estimates that Lot had 121,730 ha of forest by 1952 and 208,000 ha by 1975 . Other reports corroborate such rapid growth in forest cover by stating that Lot had 209,000 ha of forest by 1963, which was over 40\% (Service de l'Aménagement Foncier et Forestier 1963). Another report says that Lot had 213,350 ha of forest by 1985 (Ministère de l'agriculture 1985). By 1992 Lot had more forest than arable agricultural land with 216,000 ha and 214,000 ha respectively (Ministère de l'agriculture 1992).

These figures indicate that the declining numbers of farms strongly correlate with the increase of forests. There is a near perfect positive correlation of .9689 between average farm size and forest cover in Lot from 1892 to 1990, while there is a strong negative correlation between numbers of active farms and forest cover of -.7258 , which means that as the number of farms decreased and farm size increased, forest cover increased (Chambre de Commerce 1994).

These numbers confirm what I have argued that after phylloxera viticulturists moved off the coteaux because labor was scarce and increasingly expensive (Baynac 1971; Hermet 2000). The plummeting number of farmers and farm laborers meant that while land was increasingly available, much of it was difficult to work with agricultural machinery slowly introduced in Lot (Chambre de Commerce 1994). As it in the case of 
viticulture, many agricultural fields would merely be abandoned and would become reforested and largely unmanaged.

It is further striking that while scholars only a few decades before had been worried about excessive deforestation in Lot (De Lamberterie 1854), they would soon be concerned with guiding the process of massive reforestation to make it profitable (Comité départemental de production et d'Equipment agricoles: procès-verbaux des séances 1954). One official characterized the causses saying "excessive coppicing from the abuse of pastoralists has often reduced stands of Chene pubescens to 50-150 steres per hectare. Such forests occupy 75,000 ha on the causses. Half of these should be enriched with cedars or the Austrian pine (Pinus negrus)." Despite their favoring of these species for timber, the same report, written in the 1960s does still envision reforestation with oaks to produce truffles. They predicted that these forests could produce for 15-30 years, but only estimated $5 \mathrm{~kg} / \mathrm{ha} /$ year in their calculations. These plans suggested that they reforest 300 hectares for truffle production (Comité départemental de production et d'Equipment agricoles: procès-verbaux des séances 1954).

The quality of wood in Lot was $66^{\text {th }}$ among Frances départements in timber for home construction and $16^{\text {th }}$ in wood for industry. Lot's forests, by the mid-1960's, held only .4\% of France's national forest value (Service de l'Aménagement Foncier et Forestier 1964). Even worse the national average forest value was $23.55 \mathrm{fr} / \mathrm{ha}$ while in Lot it was only $2.40 \mathrm{fr} / \mathrm{ha}$. Some blamed this low value on the fact that forests were not "respected" and silvopastoralists on the causses profoundly degraded their value (Lamberterie 1874). Foresters and their laws had long sought to separate sheep, goats and forests, though such a separation proved difficult (Le département du Lot 1908). For 
officials thinking about the landscapes of the causses it was at times difficult to separate land either as forests or pastures with trees. While the dominant forest cover of oaks managed under silvopastoralism could be profitable for trufficulture under the right conditions (De Lamberterie 1874; Meulet 1899; Rey 1908) as a source of timber, these forests had little value (Comité départemental de production et d'Equipment agricoles: procès-verbaux des séances 1954).

Markets for fuelwood waned, making forests even less valuable. Markets still existed for fuelwood, especially in Toulouse until the 1940-1950s, but changes to electrical heating would eventually end these markets. This lack of household use of and markets for fuelwood was a driving factor in the 'natural' reforestation of the causses (Direction Départemental de l'Agriculture du Lot Service du Génie Rural des Eaux et des Forest 1969). Fuelwood had once had a market value of 13 million francs (Gay and Gromas 1929), which would be another source of revenue that Lot's farmers would have to eventually go without.

These expanding forests produced at times negative impacts for the farmers who had remained. They provided habitat for large mammals such as wolves and wild boars (sangliers) which could "ravage" crops (Sol 1980). Notably Delphon (1831) did not list boars as a "nuisance" animal in Lot. By the 1880s Lot began to distribute funds for the "destruction of nuisance animals". Mayors could grant permission to allow farmers to kill these animals outside of hunting seasons. Sometimes farmers would hire a team of dogs to scour the woods for certain nuisance animals. Some feared animal populations had increased during the war as hunting was less common. The community of Lauzès said it lost $1 / 2$ of its crops to boar. By 1920 there was a bounty of 30 francs per adult wild boars. 
In 1921 one official wrote: "Considering that their destruction, which increases each day, has taken on the proportions of a veritable scourge (fléau) that is coming to add to the suffering of farmers that is contributing a large part to the depopulation of the countryside." Boar would eat the winter wheat, then the roots. They would upturn the ground and eat potatoes before they could ripen. Another official wrote that "Lot must take the necessary measures to rid Lot of wild boars, which cause terrible ravages in the département. Many farmers are obliged to emigrate, because they cannot harvest their devastated fields." In 1921 farmers lost an estimated 500,000 francs in damages from wild boars. Backed by state subsidies, hunters killed 1500 adult wild boar in 1921. In 1922, a report said that losses and damage to crops from wild boar were increasing. That same year, 564 wild boars were killed in Lot. One farmer tells a story of seeing ten boars in his field. He fired shots at them, but they did not move. By 1934 there were only 103 adult wild boars killed. By the 1940s reports would argue that they were rarer (Le Département du Lot 1940). The state would eventually no longer subsidize wild boar hunts (Conservateur des Eaux et Forets au Conseil Général 1933).

\section{F. Land Cover Change in Classified Aerial Images}

Lot's forests had changed with shocking rapidity from being suitable habitat for to truffles to providing refuge for wild boar. While, I have cited figures that indicate that forest cover doubled over the second half of the twentieth century, these figures discuss the entire département of Lot (Chambre de Commerce 1994). Truffle production occurred on causses lands with certain communes dominating truffle production. No consistent data on forest cover were available at the communal level. Here I briefly leave the archives to report the findings of my classification of different historic maps and 
aerial images. I begin with this Cartes de Cassini which were completed at the end of the $18^{\text {th }}$ century. Digitizing these maps, I could quantify the built environment, agricultural lands and forest cover. The Etat Major maps, completed in the mid-19 $9^{\text {th }}$ century provided data on the same land covers. Given their scale, they did not provide any data on truffières. The most detail data source on forest cover and truffières came by digitizing land covers taken from a series of black and white aerial photographs taken between 1948 and 2000. With spatial resolutions ranging between one and three meters, I was not only able to classify agricultural areas, water bodies and the built environmental, but truffières as well. Based on my archival data I chose historic truffle producing communes such as Lalbenque, Limogne-en-Quercy (Limonge) and Martel. I classified land covers in other communities to see if the same trends occurred throughout the département. Figure 4 includes the communes included in my classifications:

Figure 4. Classified Communes in Lot, France 


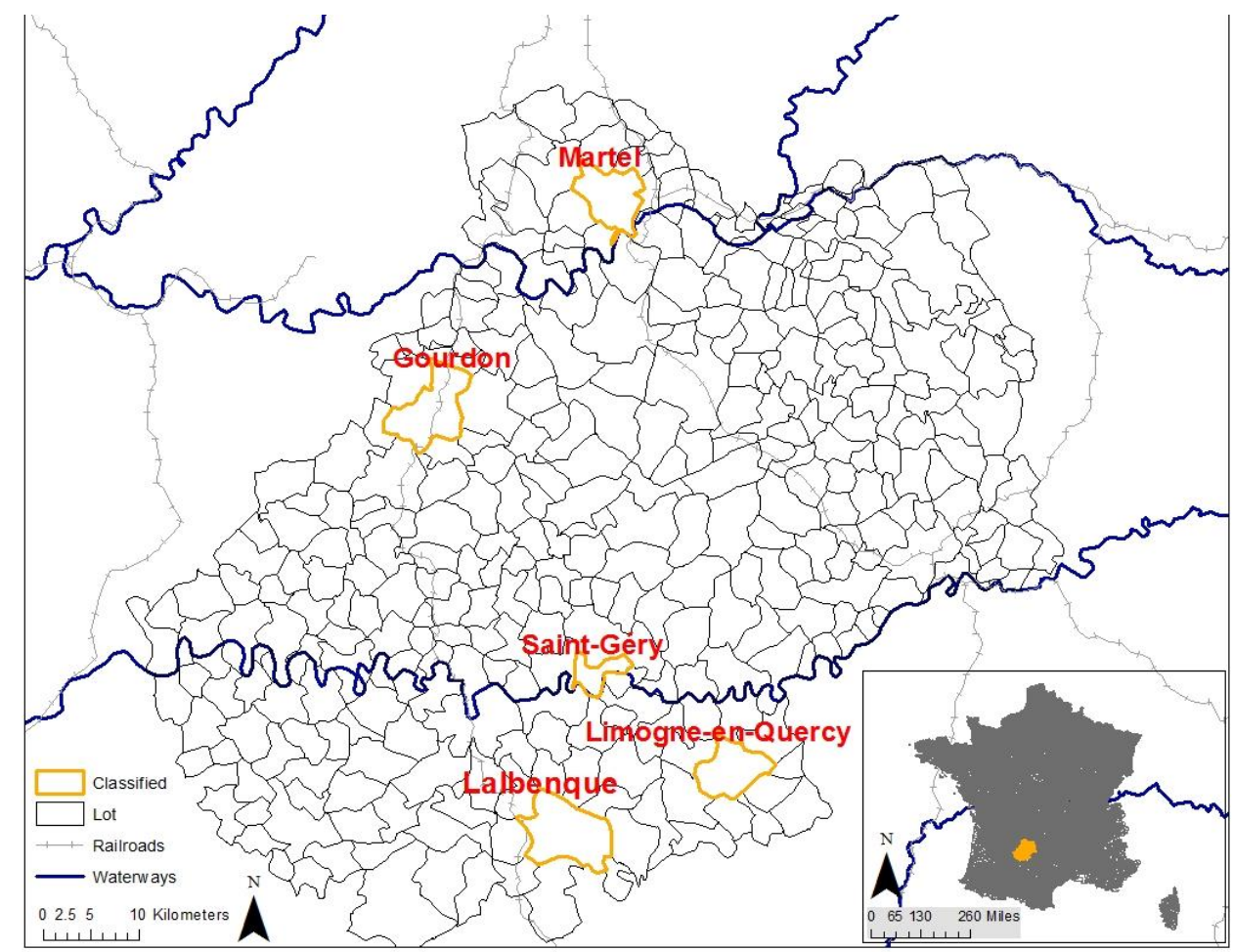

Source: IGN GIS database

I examine my results of land cover change in chronological order. Results from my classification of the Cassini maps show a landscape largely dominated by agriculture with comparatively small forested areas for all communes, with a prevalence of larger blocks of forests. Amazing only Limogne would have more than $25 \%$ forest (Table 1).

Table 7. Hectares of Forest and Field Areas from Cartes de Cassini.

\begin{tabular}{|c|c|c|c|c|c|}
\hline Commune & $\begin{array}{c}\text { Forest } \\
\text { (HA) }\end{array}$ & \% Forest & Fields & \% Fields & Total \\
\hline Gourdon & 362 & 7.97 & 4179 & 92.03 & 4541 \\
\hline Lalbenque & 855 & 16.64 & 4282 & 83.36 & 5137 \\
\hline Limogne & 816 & 25.46 & 2389 & 74.54 & 3205 \\
\hline Martel & 342 & 9.74 & 3170 & 90.26 & 3512 \\
\hline
\end{tabular}




\begin{tabular}{|c|c|c|c|c|c|}
\hline St. Gery & 645 & 53.00 & 572 & 47.00 & 1217 \\
\hline Total & $\mathbf{3 0 2 0}$ & $\mathbf{1 7 . 1 5}$ & $\mathbf{1 4 5 9 2}$ & $\mathbf{8 2 . 8 5}$ & $\mathbf{1 7 6 1 2}$ \\
\hline
\end{tabular}

Source: IGN 2016

Landscapes in Lot would continue along a similar trajectory of comparatively high proportions of fields to forests for the next century, as evidenced by classifications of the L'Etat Major maps, though these communes in general would see an overall increase in forest cover (Table 2) from Table 1.

Table 8. Hectares of Forests and Fields from the L'Etat Major Maps

\begin{tabular}{|c|c|c|c|c|c|}
\hline Commune & Forests & \% Forests & Fields & \% Fields & Total \\
\hline Gourdon & 528 & 12.01 & 3869 & 87.99 & 4397 \\
\hline Lalbenque & 660 & 13.00 & 4416 & 87.00 & 5076 \\
\hline Limogne & 851 & 26.84 & 2320 & 73.16 & 3171 \\
\hline Martel & 1258 & 30.95 & 2806 & 69.05 & 4064 \\
\hline St. Gery & 570 & 46.64 & 652 & 53.36 & 1222 \\
\hline Total & $\mathbf{3 8 6 7}$ & $\mathbf{2 1 . 5 7}$ & $\mathbf{1 4 , 0 6 3}$ & $\mathbf{7 8 . 4 3}$ & $\mathbf{1 7 , 9 3 0}$ \\
\hline
\end{tabular}

Source: IGN 2016

Unfortunately, there is no readily accessible geospatial data for roughly a century, until the French government started producing aerial images nationwide. Even by 1948, the first year of comprehensive black and white aerial images for Lot, much had changed in Lot's land cover. Since aerial images were not available for each commune in the same year, the first image is generally from 1948 with the second image in the series from 1967-1972 and the third image in the time series was taken in 2000-2004. The first classification (dark green) is for forested areas, the second (light green) is for truffières, 
the third is for fields (light brown) and the fourth (grey) is for the built environment. I did not include the number of hectares occupied by water bodies in these communes.

Table 9. Changes in Land Cover from 1948-2000

\begin{tabular}{|c|c|c|c|c|c|c|c|c|c|c|c|c|}
\hline & 1.1 & 1.2 & 1.3 & 1.4 & 2.1 & 2.2 & 2.3 & 2.4 & 3.1 & 3.2 & 3.3 & 3.4 \\
\hline Gourdon & 2200 & 85 & 2405 & 176 & 2048 & 93 & 2346 & 251 & 2333 & 57 & 1929 & 370 \\
\hline Lalbenque & 1836 & 246 & 3183 & 59 & 2131 & 116 & 3027 & 83 & 2225 & 327 & 2755 & 125 \\
\hline Limogne & 1594 & 298 & 1623 & 64 & 2068 & 125 & 1146 & 71 & 2096 & 60 & 972 & 158 \\
\hline Martel & 1256 & 258 & 2042 & 91 & 1462 & 184 & 1887 & 112 & 1602 & 84 & 1625 & 222 \\
\hline St. Gery & 845 & 15 & 460 & 49 & 905 & 7 & 399 & 23 & 1033 & 8 & 243 & 53 \\
\hline Total & $\mathbf{7 7 3 1}$ & $\mathbf{9 0 2}$ & $\mathbf{9 7 1 3}$ & $\mathbf{4 0 9}$ & $\mathbf{8 6 1 4}$ & $\mathbf{5 2 5}$ & $\mathbf{8 0 5}$ & $\mathbf{5 4 0}$ & $\mathbf{9 2 8 9}$ & $\mathbf{5 3 6}$ & $\mathbf{7 5 2 4}$ & $\mathbf{9 2 8}$ \\
\hline
\end{tabular}

Source: IGN 2016

Here we can see that overall there was a trend of increasing forest cover and in the amount of built environment, along with decreases in fields/non-forested areas and for truffières everywhere but in Lalbenque. The trends for truffières are surprisingly downward, especially in Limogne and Martel. Only Lalbenque increased the area planted in truffières. Overall, therefore the declines in area in fields was created by both increases in forest cover as well as increases in space occupied by the built environment, with truffières having limited impacts at the landscape level, though they did increase between 1968-2000 largely because of the efforts of trufficulteurs in the commune of Lalbenque. While these increases in forest cover are important, they are minimal compared to the 
land cover changes that occurred between the time of the Cartes de Cassini, L'Etat Major and the three images in time series included in these aerial images. Table 10 has the percentage change between these time periods.

Table 10. Changes in Forest Cover Percentages from Cassini to 2000

\begin{tabular}{|c|c|c|c|c|c|}
\hline Commune & Cassini & L'Etat Major & 1948 & 1970 & 2000 \\
\hline Gourdon & 8 & 11 & 48 & 45 & 51 \\
\hline Lalbenque & 16 & 13 & 35 & 41 & 43 \\
\hline Limogne & 25 & 26 & 49 & 64 & 65 \\
\hline Martel & 10 & 36 & 36 & 41 & 45 \\
\hline St. Gery & 47 & 42 & 62 & 67 & 76 \\
\hline Mean & 17 & 22 & 43 & 48 & 52 \\
\hline
\end{tabular}

Table 4 shows how in flux forest cover was in Lot, though there was a clear overall increase in forest cover. Between the 1790s and mid-1800s, there was an increase in forest cover in these communities, though largely because of substantial increases in Martel. Yet these first classifications seem as an overestimation as my data show that Martel lost forests between the mid-1800's and 1948. In the same period, the forest cover in Gourdon increased by over 300\%. The period with the greatest change was that of L'etat major (mid-1800s) until the mid-1948 when forest cover increased by nearly $100 \%$. Only the commune of Gourdon lost forest cover between the first two aerial images, while in every other case communes showed increases in forest cover with the three truffle-producing communes having the greatest increases in forest cover from 1948- 1968, though smaller increases came between $~ 1968-2000$. 
Yet even if the period between 1948-2000 did not have as dramatic changes as the preceding century, a more explicitly spatial analysis of land cover change illustrates how the size of forest areas increased in a way that produced large blocks of forest areas, while the central area of Lalbenque retained its agricultural areas. The northern tip of Lalbenque became increasingly forested with large areas of tree cover. The commune of Lalbenque demonstrates these trends well, though again, Lalbenque was the only commune to have significantly replanted truffières. Another damaging change is that many of these new truffières are surrounded by large forested areas in the commune's southern end as well as how much less patchy forests became. These images also demonstrate how despite declines in human population, the built environment has notably expanded in scope even as populations did not explode (Figure 2).

Figure 6. Land Cover Change in Lalbenque 1948-2000. 


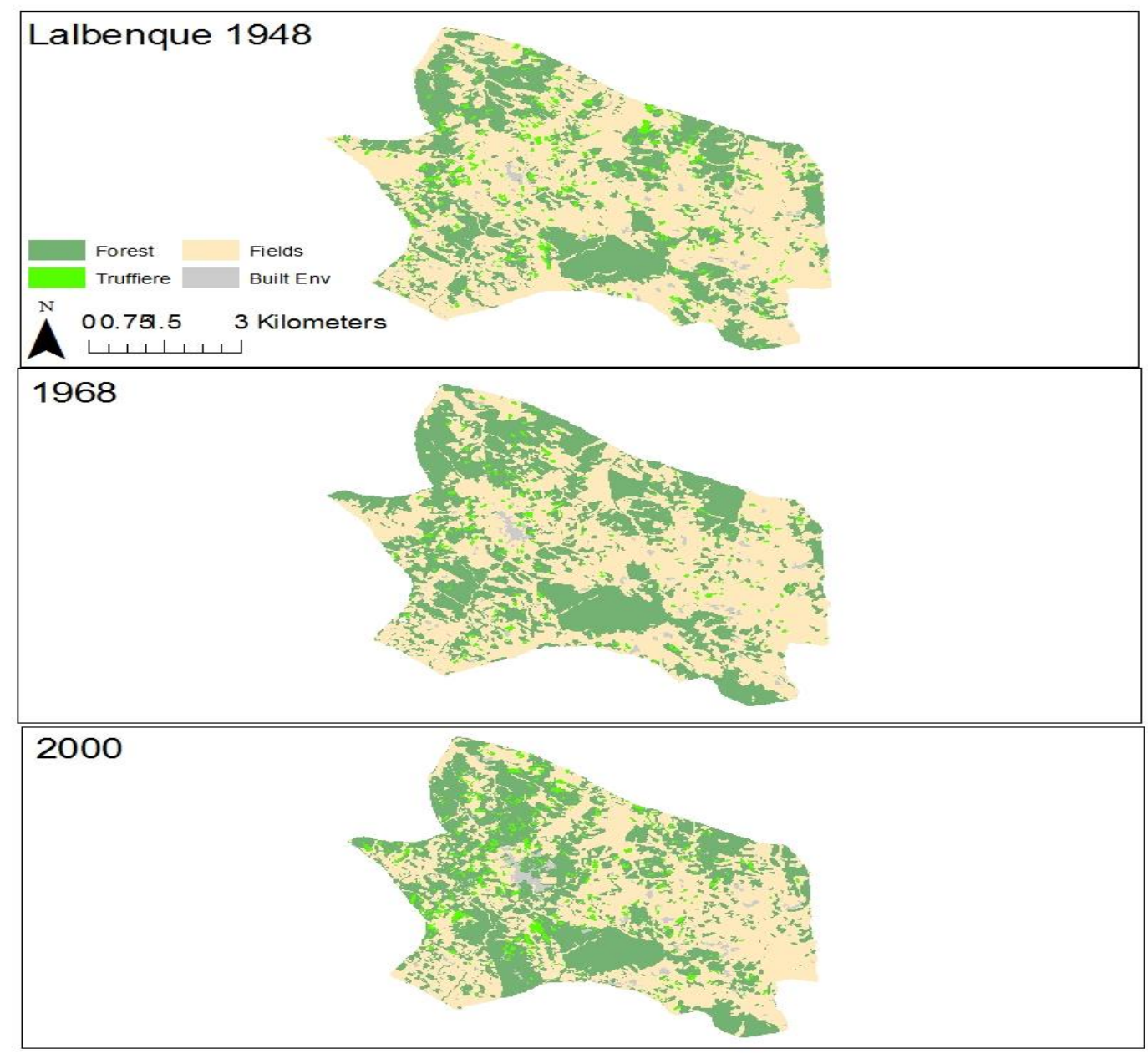

Source IGN 2016

Finally, my LANDSAT analysis indicates that at the départemental level Lot gained 15,887 hectares of forest from 1975-2015. These five communes analyzed here gained 1558 ha of forest between 1948-2000. Therefore, the general trends in these communities do bear out for the rest of Lot, even if they seem to have experienced greater than average reforestation outcomes compared to the rest of the département. It is foreboding for the future of trufficulture that forest cover increases in Lot have gone unabated for nearly 70 years. Yet data from Lalbenque shows that farmers worked hard to replant their truffières from 1968-2000. These increases were even large enough to 
arrest losses in other communes. Trufficulture once again interested farmers in Lalbenque. Yet in other once important truffle-producing communes like Martel and Limogne, it did not. According to Castelnau (1978), the truffle had "migrated" to the south not because of any phenomenon other that trufficulture became rarer in Martel and comparatively more common. Lalbenque's more energetic replanting has unseated Martel from its once dominant place in trufficulture in Lot (Champagnac 2000; Larue 1906).

Despite these encouraging trends in Lalbenque, I have presented little else that is cause for hope in this chapter. Lot underwent a revolution of its agricultural and overall population. As both populations plummeted, truffle production followed. Anything but a coincidence, trufficulture was severed from the many other actor-networks that sustained it. The truffle had long thrived at the edge of pastures, in junction with silvopastoralism (Delpon 1831; Rey 1889). First wool imports undercut prices in Lot, meaning that sheep would only be raised for meat. Trying then to increase production, the government convinced farmers to end extensive silvopastoral practices and the plant 'improved' pastures where they would raise sheep more intensively. Therefore, in a large part sheep were removed from the forests, the very forests they would have helped to maintain in favorable conditions for Tuber melanosporum (Castelnau 1978; Le Tacon et al. 2014).

As previously discussed the phylloxera aphid and difficulties of producing hybrid plants that could thrive on the coteaux and causses meant that viticultural moved primarily to fertile valley lands. The delimitation of the Cahors AOC zone would favor communes in the Lot River Valley, communes that had really produced too many truffles. This area would be vastly smaller than the areas once occupied by viticultural in Lot (Baux 1982). The few archives that do discuss trufficulture do not discuss them in the 
context of viticulture, the way scholars had once done (Bosredon 1887; Meulet 1889). Therefore, as with changes in sheep raising, viticultural became a monoculture and severed from its relations from trufficulture. While there seemed to be some complementary relations between grapevines and truffles, these associations would become that much less common (Castelnau 1978). While Bosredon (1887) recommended that farmers plant cereals around a truffière, cereal cultivation also become much rarer also because of national and international competition. Lastly, technological changes meant that farmers did not have to harvest fuelwood, while markets dried up as well.

These phenomenon that altogether equate to agricultural modernization and specialization were catastrophic for truffle years. More truffles moved through a single market in the early 1900s than Lot's entire production in the early 2000s (Mayssonnier 2010; Sourzat 2009). Reforestation, what had done so much to raise production towards 2000 tonnes (Chatin 1892; Pradel 1914; Valserres 1874), now made conditions unfavorable for Tuber melanosporum Different species thrived in these new forests from wild boar to other fungi. As people abandoned many of Lot's forests, soil conditions changed. These new forests masses may have altered local climates (Castelnau 1978; Gaignebet 1923). Scholars had long recognized how important sunlight penetration and soil aeration were for Tuber melanosporum. Unmanaged forests often provided neither.

These new actor-networks created a paradoxical moment in Lot. Tuber melanosporum, a mycorrhizal mushroom, was less abundant as forests became abundance. Forests, closed canopy, unmaintained forests hurt production. A forest is not a forest. As always changing relations in an actor-network alter all actants. The absence of grapevines, fields of cereals, sheep and farmers changed landscapes and the forests in 
which the truffle once thrived. The truffle, which had spurred so much replanting in the wake of phylloxera (Champagnac 2000), would become a victim of unchecked reforestation. In my classification of historic aerial images, I watched such processes before my eyes. I watched as the sparsely forested communes of the early and middle $19^{\text {th }}$ century turned by the end of the $20^{\text {th }}$, into heavily forested areas. Between each time series, I analyzed individual truffières transform into closed canopy forests. I wondered at what point they stopped even having the possibility of producing T. melanosporum. At some moment a formerly productive truffière would transition into a mature forest, a transition which would liquidate another source of revenue when few remained.

Yet had these associations continued unabated, this dissertation might have been totally historic in nature. Instead, by the 1960s a movement began to try to relaunch trufficulture in Lot and other truffle-producing communes in France. Not only did newly formed associations and syndicate help motivate farmers to create truffières, scientific inquiry recommenced at a rapid rate. Scientists could mycorrhize/inoculate the roots of the truffle's host trees with truffle spores (Champagnac 2000). This association had been the main long-standing mystery of trufficulture (Pradel 1914). Yet as groundbreaking as such worked seemed, I will describe how it did not instantly create a stabilized actornetwork. Instead, many "betrayals" (Callon 1984) awaited these plants.

While I focus on how scientists rethought a multitude of actants' ontologies to produce what they would call "modern" trufficulture, I analyze the difficulties in actually implementing "modern" trufficulture in Lot by surveying current trufficulteurs. I find that instead of a single "modern" trufficulture in Lot, that trufficulteurs have adapted these 
practices with great "fluidity" (de Laet and Mol 2000) that comprise the different constraints on their management. Many trufficulture( $s$ ) are in fact practiced in Lot. 
Chapter 5: The Development of "Modern" Trufficulture and Its Fluidity in Lot

\section{A. Introduction}

I begin Chapter 5 by describing how after a sixty-year drought of scientific research on trufficulture, by the 1970s there was a surge of interest in remaking trufficulture through "modern" scientific applications and the utilization of modern farm machinery and infrastructure. Scientific research dramatically complicated former versions of trufficulture. Fundamental actants like host tree saplings and truffle spores interested international scientific actor-networks. Scientists would even sequence the truffle's DNA. This work shows that the truffle produces sexually, and not asexually, as was long assumed. These scientific developments both open new avenues for restoring truffle yields, while also exposing just how mysterious the truffle remained. All in all, these scientists produced a radically different actor-network for the truffle. Yet these new actor-networks, young as they are for a crop so slow to enter production, have yet to produce any clear guidelines or improvements for trufficulture. Such scientific findings need to be "translated" (Callon 1984) by practicing trufficulteurs. Other forms of "modern" agriculture and forestry have transformed farmers as much their farming systems (Cullather 2010; Tsing 2015). Trufficulteur may need such transformations.

In the second half of this chapter, I describe in various ways in which Lot's trufficulteurs are translating "modern" trufficulteur. I present the results of semistructured survey interviews which I conducted with trufficulteurs in Lot about their ecological understandings of trufficulture, the truffle's place in Lot's economy and their idea about the cause of truffle declines as well as their prognoses for the truffle's future in Lot. In effect, I show how difficult it is to fully implement "modern" trufficulture in Lot. 
Different farm circumstances, motivation for becoming trufficulteurs, economic aims and understandings of truffle ecology all inform the ways that trufficulture is being practiced on the ground. I find great "fluidity" (de Laet and Mol 2000) in trufficulture that unevenly implements scientists' recommendations.

\section{B. "Inoculated" Plants: When Trufficulture Becomes "Modern"}

The moment that trufficulture becomes "scientific" or "modern", for many, came with the creation of "mycorrhized" plants/saplings (called plants mycorhizés in French), whereby the roots of saplings were "inoculated" with truffle spores to promote ectomycorrhizal symbiosis between truffle spores and its host tree (Callot 1999; Grente and Delmas 1974; Rebière 1974). Ever since scholars discovered through microscopic analysis that the truffle was a mycorrhizal mushroom in the late 1800s. They realized that this relationship was necessary for truffle production (Bonnet 1869; Bosredon 1887; Chatin 1892). While people tried to ensure these relationships through the in-situ production of apt host tree species raised in soil 'seeded' with truffle spores, no testing took place to verify that mycorrhization had occurred (Pradel 1914). Without such verification, it was mysterious why certain trees would produce while others crafted from the same acorns and truffle spores would not (Chatin 1892; Pradel 1914). Mycorrhization, the verification of truffle/host tree symbiosis would hypothetically remove such mysteries.

While Australian foresters had successfully "inoculated" pines with fungi mycelium, Italian and French scientists would make important advancements in the 1970s regarding the inoculation of Tuber sp. in oaks and other common host tree species. While these Italian mycologists like Bruno Fassi and Anna Fontana successfully 
"inoculated" plants in laboratory conditions with Tuber melanosporum, it was their collaboration with French scientists like Jean Grente and Gérard Chevalier, working for France's governmental National Institute for Agronomic Research (INRA), that allowed scientists to able to "scale up" the projects by 1972 . They then begin to "inoculate" plants for the French market, starting with oaks "inoculated" with Tuber melanosporum spores (Callot 1999; Murat 2015). However, instead of having these state agencies produce plants for market, they argued that only outside firms could satisfy national demand (Champagnac 2000; Olivier et al. 2012).

By 1973 a newly created firm, AGRITRUF, produced 9,500 "inoculated" plants for sale to French trufficulteurs. Other private firms like Robin would also produce inoculated plants not only for T. melanosporum, but other truffle species as well. The two firms now produce 200,000 inoculated plants for an international market. Other French firms produce another 100,000 plants, while firms in Spain, Italy, Australia and New Zealand produce at least another 200,000 plants per year for a global total of 500,000 (Murat 2015). These increases in the production of "inoculated" plants also led to an increase in the planting of truffières throughout France. Trufficulteurs have planted roughly 8000 ha or nearly 250 ha a year with these "inoculated" plants. Trufficulteurs were able in some cases to receive partial subsidies for creating new truffières with these “inoculated" plants (Callot 1999; Champagnac 2000).

\section{Problems with Inoculated Plants}

Inoculated plants were supposed to solve various 'problems' of 'non-inoculated' plants which had been previously produced by trufficulteurs themselves (Callot 1999; Fischer and Colinas 1996). First, these commercially "inoculated" plants were an attempt 
to arrest ongoing declines in truffle production by trying to ensure the symbiosis between truffle spores and their host tree (Rebière 1974). Another perceived advantage of these commercially produced "inoculated" plants was that production started as early as 3-4 years instead of 10-15 years, delays which had caused some to quit maintaining their truffière (Callot 1999; Sourzat 1994). Though Valserres (1874) cites that historically production could occasionally begin as early as four years in non-inoculated plants, such precocity is thought to be more common in "inoculated" plants (Callot 1999; Sourzat 2009). On a practical level, more precocious production would diminish the investments and labor a trufficulteur would undertake before they would start receiving revenue from truffle harvests (Oliver et al. 2012).

Bonet et al. (2009) cite high per hectare yields for truffières created with “inoculated" plants such as $45 \mathrm{~kg} / \mathrm{ha}$ for irrigated plantations in parts of Spain and 15 to $50 \mathrm{~kg} / \mathrm{ha}$ for 14-year-old plantations in France. While these yields are exceptional today, they are mediocre compared to past yields (Bonnet 1869). With dramatically climbing prices over the last century, which range from 300-500 Euros $/ \mathrm{kg}$ and often rise to 700900 Euros/kg in years of low production, today's productive truffières are more profitable per hectare than truffières from the late 1800s when national truffle production had peaked (Chatin 1892; Olivier et al. 2012). By the 1940s rising prices had already begun to make up for massively declining yields (Castelnau 1978).

Yet such high current per hectare yields with "inoculated" plants prove to be largely anecdotal. New plantings should have led to dramatic increases in truffle production, which has not happened (Callot 1999; Mayssonnier 2010). Callot (1999) uses three models to predict truffle production: "maximum production" of $30 \mathrm{~kg} / \mathrm{ha}$ from the 
first 10-20 years, $60 \mathrm{~kg} / \mathrm{ha}$ from 20-30 years and $90 \mathrm{~kg} / \mathrm{ha}$ from its 30 th year and beyond, “average production" of $15 \mathrm{~kg} /$ ha for $10-20$ years, $30 \mathrm{~kg} / \mathrm{ha}$ from $20-30$ years and 45 for years 30 and over, while "minimal production" would be $3 \mathrm{~kg} / \mathrm{ha}, 5 \mathrm{~kg} / \mathrm{ha}$ and $9 \mathrm{~kg} / \mathrm{ha}$ for the same periods. Yet with an average national production of 30,000 kgs a year, these 8000 ha (Callot 1999) produce only roughly $3.75 \mathrm{~kg} / \mathrm{ha}$. This estimate also makes the bold assumption that the only truffières that are productive are those which trufficulteurs recently created with "inoculated" plants. What is clear then is that truffières created with “inoculated" plants have failed to average Callot's (1999) rates of "minimal production", even if certain truffières did produce well (Bonet et al. 2006). Such data show that “inoculation” has been anything but a panacea for trufficulture (Mayssonnier 2010).

One frequently discussed problem with these "inoculated" plants begins in the nursery itself. Champagnac (2000) details how some early adopters were critical of the stunted (chétifs) nature of the "inoculated" plants, while researchers argued that these were the kind of saplings that would survive drought and live to produce truffles. Here they somewhat echo past ideas that the confirmation of a sapling would show its “aptitude" (Pradel 1914), while adding the additional assurance that "inoculation" under sterile laboratory conditions should lead to the production of the target species and/or that target species alone (Champagnac 2000).

\section{In Situ and Ex Situ Fungal Contamination}

Other problems would be far greater and of more lasting concern. While scientists attempt to "inoculate" saplings with only Tuber melanosporum spores that "colonize" the host tree's root tips, spores from other truffle or fungal species may "contaminate" these plants in the nursery. Instead of using microscopes to "certify" that plants are only 
"inoculated" with Tuber melanosporum spores, some argue that costly DNA testing is necessary so as not to confuse morphologically similar species like Tuber brumale or $T$. indicum with T. melanosoporum. Such confusion leads to increased "contamination" (Murat 2015). Here, similarities in truffle morphology make the microscope a potentially untrustworthy actant in "certification" of mycorrhized plants.

Such mistakes in the nursery then mean that trufficulteurs might introduce these undesirable truffle species into truffières in which they may or may not have been previously present. Murat et al. (2008), in the evocatively titled paper, "Is the Perigord black truffle threatened by an invasive species? We dreaded it and it has happened!", describe how trufficulteurs had bought "inoculated" plants which they planted in Italy in the attempt to promote $T$. melanosporum, but instead ended up accidently introducing the Chinese black truffle (T. indicum). It is morphologically like T. melanosporum but is of far less value. Plant certifiers may have mistaken it $T$. indicum for $T$. melanosporum under the microscope and allowed it to pass inspection.

Murat et al. (2008) worried that $T$. indicum may become "invasive" in Italy, a historic truffle-producing country, and in the new-to-trufficulture, USA as well. Such unintentional introductions complicate the history of "inoculated" plants which already promoted the growth of $T$. brumale, a 'native' European truffle with less market value than T. melanosporum. With the global trade in "inoculated" plants, "contamination" has unintentionally moved non-target truffle species around the world both within and outside of T. melanosporum's 'native' range (Murat 2008; Olivier et al. 2012). Such "contamination" will have impacts on these new areas of trufficulture as well as historic ones (Stobbe et al. 2013). These large movements of truffles were only a dream in the 
$19^{\text {th }}$, while many argued that only areas in the truffle 'natural' ecological distribution would produce truffles in high quantities (Chatin 1892; Mouillefert 1904). Inoculated plants have dramatically extended actor-networks (Hall et al. 2007).

With people concerned about the presence of these low-priced and often underripe Chinese black truffles in the French market and the possibilities of fraud (Olivier et al. 2012), Murat et al. (2008) raise the specter of the accidental introduction of the Chinese truffle into truffières in France, as had already occurred in Italy and the United States. 'Native' species like T. brumale had already devalued French truffières, though the much less valuable $T$. indicum could further devalue them (Murat et al. 2008).

Considering such widespread contamination, it may not be surprising that there is a wide diversity of plant certification methods for T. melanosporum (Andrés-Alpuente et al. 2014). Issues come from contamination but also from the percentages of colonized root tips necessary in sampled inoculated plants to pass inspection. To pass INRA's governmental inspection, plants need to be free of contaminates and have a certain percentage of their root tips "colonized" by T. melanosporum spores. In testing inoculated plants produced in Spanish nurseries, Andres-Alpuente et al. (2014) show that the most liberal criteria, which were the first standards developed in France, led to only one in ten sample batches being rejected, while under the most "conservative" standards seven in ten batches were rejected.

Standards have grown more rigorous through time, yet these criteria are not standardized and plants on the market can come from any method of inoculation, even those which produced rather high rates of contamination and low truffle production in the past. Depending on the method of inoculation, one may have few colonized root tips with 
contamination (Andres-Alpuente et al. 2014). Alvarado and Manjon (2013) argue that low rates of colonization in plant nurseries may lead to higher levels of contamination once they are transplanted into truffières. The actor-networks of the lab and the truffière become more intimately linked after poor inoculation.

The success of transplants seems to further depend on the density of preexisting spores in the potential truffière. Sourzat (1994) concurs that the planting of plants poorly colonized by T. melanosporum can lead to host trees searching for other fungal symbionts and to in situ contamination by T. brumale. T. brumale produces far more spores and can more easily take advantage of different ecological niches than T. melanosporum. There is a strong relationship between lack of $T$. melanosporum colonization and undesirable contamination as other truffle species can form relations with non-colonized root tips (Murat et al. 2008; Sourzat 1994). Different methods of tilling the soil can also increase the risk of contamination by species like T. brumale (Sourzat 2009).

To make matters of contamination that much more complicated, Sourzat (1994) argues that certain host tree species are more susceptible to contamination than others. For a while, scholars thought that Corylus avellana (known as the common hazel in English and noisetier in French) was the more "precocious" producer of $T$. melanosporum, known to produce after only 4 years. When planted, they found that hazel trees often had strong associations with $T$. brumale in southwest France. The same findings in Spain have caused some to argue that these trees should not be planted (Bonet et al. 2009), though they produce well in areas of New Zealand, which do not have $T$. brumale as a 'native' or imported fungi (Olivier et al. 2012). 
Quercus ilex (holm oak in English and chêne vert in French) better resists drought and often produces sooner than other oaks at six years, and more frequently associates with T. melanosporum than other mushrooms, though it is susceptible to frost. (Bonet et al. 2009; Sourzat 1994). Quercus pubescens (the downy oak in English and chêne pubescens in French) better handles frosts but often starts producing mainly $T$. melanosporum much later, after 10-15 years. While Q. pubescens is more common in southwest France, $Q$. Ilex is more common in southeast France (Sourzat 1994). The same general geographic distribution of these trees remained in place for over a century (Chatin 1892; Valserres 1874), while Bosredon (1887) had recommended the planting of Corylus avellana to earn revenue from hazelnuts as well as truffles. However, it seems that hazels have increasing problems with contamination and that the oaks have less propensity for "contamination" (Sourzat 1994).

\section{E. The Costs of Modern Trufficulture}

Therefore, we have a wide variety of opinions on host trees (Sourzat 1994) and certification methods (Andres-Alpuente et al. 2014), issues with contamination (Murat 2015) and yields well below predictions in some cases (Callot 1999). Less discussed is how much more expensive these inoculated plants are than alternative methods, whereby the trufficulteur produces plants in an onsite nursery and hopes for pre-existing spores to "mycorhize" these plants (Mayssonnier 2010; Sourzat 1994). Some recommend placing "inoculated" plants in densities of 6 meters by 6 meters, which is roughly 280 per hectare (Korkmaz and Turkoglu 2015), though Sourzat (1994) recommends densities of 4 meters by 6 meters or 400 plants per hectare, while Bonet et al. (2006) cite common densities of $6 \times 5 \mathrm{~m}, 6 \times 6 \mathrm{~m}$ and $6 \times 7 \mathrm{~m}$. If one takes Sourzat's (2009) estimate of 400 saplings for a 
single hectare of truffière then one would spend today roughly 5172-10,254 Euros for the "certified" plants alone, depending on the ages of saplings. This total does not include the labor costs needed to prepare the ground and plant them. Some have critiqued these high costs for inoculated plants as their yields are undependable (Mayssonnier 2010).

Furthermore, this amount does not include the wiring and plastic baskets needed to protect these trees from rabbits and deer which can damage or kill young seedlings (Sourzat 1994). While some of the scholars of the truffle's "golden age" (Chazoule 2004) do mention that other species could be the "enemies of the truffle" (Chatin 1892) no manuals or photos of old truffières suggest that trufficulteurs need to take such measures as installing protective devices around their new saplings to prevent damage from deer and wild boar. If anything, they were more worried about domestic animals damaging trees (Bosredon 1887) while current trufficulture are concerned about deer and wild boar that damage samples and soils in a truffière (Sourzat 1994).

Therefore, these investments are significantly more expensive than those methods described by Pradel (1914) of producing, selecting and transplanting "apt" plants that the trufficulteurs themselves produced. Returning to the "certification" process of inoculated plants, the more rigorous the method of detecting root colonization and contamination detection, the lower percentage of saplings will make it to the market, which will further impact prices (Andres-Alpuente et al. 2014). Yet in home production and large commercial nurseries, Sourzat (1994) describes how some smaller nurseries mimic many of the techniques of the larger nurseries but are not able to offer the same guarantees of certification granted by the French government through INRA. These uncertified plants may be susceptible to contamination. 
In fact, the French government, whose state agencies had 'scaled up' the production of certified and inoculated plants, granted these techniques to private nurseries to produce and sell these plants to trufficulteurs (Callot 1999; Murat 2015). Those without this relationship could not produce "certified" plants (Sourzat 1994). "Certification" is no panacea, as plants have had low rates of inoculation and high degrees of contamination (Andres-Alpuente et al. 2014; Murat 2008). They demand considerable outlays of money (Mayssonnier 2010). Yet, these plants "interested" trufficulteurs to replant truffières (Callot 1999). Trufficulture also gained subsidies for the planting of "inoculated" plants, making them more attractive (Champagnac 2000).

\section{F. A Changing Truffle and the Loss of Virulence}

Sourzat (2009) provocatively offers an alternative view as to why many truffières have low levels of colonization of T. melanosporum and high degrees of "contamination" in "inoculated" plants both in the laboratory and in truffières (Andres-Alpuente et al. 2014). Sourzat (2009) argues that the cause is not necessarily poor laboratory practices, "cultural" methods or the choice of host trees species. What may drive "contamination" is the winter black truffle itself, $T$. melanosporum. It may have lost its competitive edge, it's "virulence", against other fungal species because of environmental changes over the 20th century (Sourzat 2009). Changing actor-networks have altered T. melanosporum.

In fact, former scholars mention that when trufficulteurs had planted oaks in between grapevines that $T$. melanosporum would eventually kill these grapevines and other surrounding vines through the tree's production of burned areas (brûlés) (Bosredon 1887; Rebière 1974; Valserres 1874). Here the "virulence" of the truffle restricts wine's reproductive and livelihood strategies (Olivier et al. 2012). This "virulence" has a spatial 
dimension as the trees roots and symbiotic truffle mycelium undertake the "conquest of space" by extending its brûlés outward to create the proper milieu for T. melanosporum (Olivier et al. 2012). The failure to act with "virulence" to continue its "conquest of space" (Olivier et al. 2012; Sourzat 2009) means that the truffle itself is not maintaining its favorable milieu for high production (Olivier et al. 2012). In this view, the balance has tipped away from T. melanosporum in questions of fungal competition and towards more "plastic" fungal competitors. Therefore, T. melanosporum may not be able to flourish in lands where it once did (Sourzat 2009).

In summation, the related processes of failures of "colonization" and fungal "contamination" can happen in the laboratory (Andres-Alpuente et al. 2013), in the host tree species (Sourzat 1994; Olivier et al. 2012), in the practice of trufficulteurs (Chevalier and Pargney 2014) or in a lack of "virulence" of T. melanosporum (Sourzat 2009). Within this complex "hybrid-actor network" (Latour 1993) these "inoculated" plants can have very high yields (Bonet et al. 2006) or very low yields (Callot 1999). As costly as "inoculated" plants are, they have not proven to be a panacea (Mayssonnier 2010). Therefore, truffle scholars continue to explore new ways of understanding the truffle itself, and its relations with other actants. In trying to restore truffle production, scholars have found that they may need to introduce a whole new set of actants (Latour 1987) to strengthen a less virulent truffle (Sourzat 2009). As inoculation produced as many questions as it did answers, truffle scholars have had to go deeper into the truffle's ontology, in hopes of "taming" it (Hall et al. 2007).

\section{G. Geneticists' Understandings of Tuber melanosporum}


While DNA analysis may help limit further contamination of inoculated trees (Murat 2015), it has reordered the truffle world in surprising ways. DNA analysis has led to reclassification of some important commercial truffle species as well as new understandings of said species. While Chatin (1887) had argued that the Burgundy Truffle (Tuber uncinatum) was a separate species from the summer truffle (T. aestivum) recent analyses have classified them as a single species (Mello et al. 2006; Olivier et al. 2012), which should be called T. aestivum across its large geographic range from Spanish to Sweden (Weden et al. 2005).

DNA research has transformed T. melansoporum as well. Scholarly work has demonstrated genetic diversity through its geographical range, though not enough to consider these populations as distinct species (Martin et al. 2010). The genetic diversity present in T. melanosporum has many implications. It complicates the influences of local 'environmental' factors of the aromas and tastes of truffles that produce "terroir" (Mello et al. 2006). Further research into truffle genetics and its diversity tells a story of the truffle since the last ice age and how scientists believed it survived in warm refuges where oaks could thrive (Mello et al. 2006). Previous works had only traced the history of truffles to the Greeks and Romans (Chatin 1892). Now DNA has continued the history of the truffle into the more distant past. Furthermore, these isolated ice age refuges have influenced genetic variation in T. melanosporum across its 'native' range in France, Spain and Italy (Agueda et al. 2014; Mello et al. 2006).

Yet new technology has further changed understandings of individual truffle species as they have allowed scholars to sequence T. melanosporum's DNA (Martin et al. 2010; Rubini et al. 2011). Such refined genetic analysis sheds light on the truffle's 
reproductive cycles (Callot 1999). Recently, scientists have found that $T$. melanosporum is heterothallic, or having different mycelia participating in sexual reproduction instead of asexual reproduction or "selfing" (Rubini et al. 2011). Further work showed that different mating types of T. melanosporum were not compatible with one another. Therefore, it is necessary that different mating types be present and in contact in a truffière. If certain plants only have a single mating type of truffle spore in actual truffières, then they cannot reproduce and these host trees can be colonized by other fungal species.

These different mating types being available in a truffière, is a sexual process that Rubini et al. (2013) have likened to "Romeo" finding his "Juliet" as spores of different sexes must find each other in a truffière. T. melanosporum must find its mate in the soil. Scientists have yet to be able to reproduce this coupling in laboratory conditions but have detected it in productive truffières. Considering these findings, Stobbe et al. (2013) argues that DNA analysis of inoculated plants should consider the presence of different mating types to ensure higher rates of colonization in transplanted saplings. The truffle does not just relate with its host tree, but also with other truffle spores, which then ensures successful colonization" (Agueda et al. 2010).

DNA-analysis also has been able to confirm just how much T. melanosporum alters mycological diversity, seen when it transforms its surrounding areas by creating denuded 'burned' areas (brûlés), processes like what Olivier et al. (2012) have called "the conquest of space". To prepare its environment, it will reduce mycological diversity compared to nearby areas. Tuber melanosporum reduces competition from other fungi to thrive (Napoli et al. 2010). Belfiori et al. (2012) confirm that ectomycorrhizal diversity was greater in "natural" truffières than in "cultivated" ones, showing that truffle species, 
when successful, outcompete other species. If it creates expanding brûlés, the truffle has "virulence" against competitive fungi (Sourzat 2009). Its use of "phytotoxic" chemicals removes other species, while some argue that the truffle also uses allelopathy that transforms its environment in complex ways (Streiblvoa et al. 2012). This work shows how profoundly T. melanosporum can modify its milieu (Belfiori et al. 2012). It creates multiple effects; it literally affects local biodiversity (Napoli et al. 2010). Therefore, the truffle is not affected by changing forest biodiversity, it seems to affect it as well.

Further complicating this actor-network, scientists have found bacteria present on the outside (peridium) as well as the inside (gleba) of T. melanosporum that are not found in the soil. While nearly all European truffle species have Bradyrhizobiaceae bacteria present through their entire life cycle, some bacteria are found more exclusively on $T$. melanosporum (Antony-Babu et al. 2013). As these bacteria appear to be vital to the truffle itself and its exchanges with its host, Antony-Babu et al. (2013:10) demonstrate heretofore unknown associations and recent work that: "suggests that the soil constitutes a reservoir of biodiversity, from which specific bacterial communities are differentially recruited in the ascocarp [fruiting body] and in the 'ectomycorrhizosphere'." They show that certain bacteria may play a decisive role in the maturation of the truffle. It is unknown if these bacteria have a symbiotic or parasitic relationship with the truffle through its lifecycle (Antony-Babu et al. 2013). Such relationships show that the truffle as we know it is an effect of its own complex actor-network of yeasts and bacteria.

\section{H. Chemists' Understanding of T. melanosporum}

It is the unmistakable aroma and flavor of the truffle that inspired Brillat-Savarin (1825) to call T. melanosporum a "diamond of cuisine." Yet attempts to understand these 
aromas by earlier scholars produced inconclusive results (Chatin 1892; Grimblot 1878). A growing group of studies have attempted to understand what makes the truffle a "diamond" through the analysis of its volatile organic compounds (VOCs), which produce the unique aroma of Tuber melanosporum and other truffle species. Increasingly sensitive machinery has continued to identify VOCs (Splivallo et al. 2011) with more than 200 VOCs already identified. Techniques often include the use of "headspace solidphase microextraction (HS-SPME)" and "gas chromatography/mass spectrometry (GC/MS)", with the former being simpler and more cost effective, and the latter more expensive and sensitive (Gioacchini et al. 2008). These VOCs affect truffle aromas and allow it to further impact its milieu (Antony-Babu et al. 2013).

The release of VOCs by the truffle has important ecological implications. Through the release of VOCs, the truffle 'acts'. These VOCs are a main reason that a wide variety of animals are attracted to the truffle from flies to large mammals who help disperse its spores. Truffle harvests are made possible by trained pigs and dogs that can detect the VOCs, particularly dimethyl sulfide, which is produced by ripe truffles. These VOCs also attract the flies some truffle hunters look for to locate truffles. Furthermore, some VOCs may help to "modulate" tree root growth to increase the probability of symbiosis of its mycelium with its host tree.

Different VOCs appear to be responsible for the formation of brûlés which denude the soil of surrounding areas that appear before fruiting bodies. The VOCs, which in great enough concentrations can act as herbicides, alter its environment. Yet the truffle is not acting alone. Research has shown that its VOCs are caused in part by associations it forms with different bacteria (Antony-Babu et al. 2013; Splivallo et al.2011) and yeasts 
as well (Mello et al. 2006). These findings show that what we call the truffle is itself a product of a variety of associations with these recently 'discovered' nonhumans.

These chemical studies demonstrate new and more complex actor networks considering the role that bacteria and yeasts play in the lifecycle of the truffle. The truffle is not alone, or wholly apart of these bacteria and yeasts that it may need to fulfill basic lifecycle functions (Antony-Babu et al. 2013; Mello et al. 2006). These studies also show how the truffles' aromas are not just the cause of its global culinary reputation, but also attract nonhuman species who spread its spores to the tree roots with which it forms the essential ectomycorrhizal relations and bacteria which help it thrive (Splivallo et al. 2010). Such fascinating studies greatly complicate truffles as actor-networks.

\section{Implementing "Modern" Trufficulture in Lot}

What is notable about the above scientific work is how while scientists are trying to construct new trufficulture actor-networks, problems like contamination and a loss of "virulence" became prevalent. These errors are not easy to rectify since one usually waits 10 years to begin see results in a truffière. With the rapid accumulation of scientific knowledge described above, the task of aligning the actual practice of trufficulture to new scientific knowledge is incredibly complicated. Also, the modern practices proposed above rarely consider the farmer who is meant to implement them. With the costs continuing to rise, fewer trufficulteurs may be capable or interested in taking on such investments for yields that remain unpredictable.

As I will show in the following results of my semi-structured survey, few trufficulteurs in Lot have adopted the full recommendations of "modern" trufficulture. Instead, of one standard series of practices of trufficulture in Lot, there is considerable 
"fluidity" among the 42 surveyed trufficulteurs. These differences exist largely because of different farm investment levels, age and status of succession, ecological understandings of truffles and economic or noneconomic motivations. Therefore, while they experience problems with fungal contamination, low rates of colonization by Tuber melanosporum and attacks from deer and wild boar, their practices often diverge from scholar's recommendations. When trufficulture leaves scientists' labs or experiment truffières, it becomes something else in Lot. Describing trufficulture in Lot will help to explain why the truffle is not "tamed" (Hall et al. 2007) and why it is unlikely that another "golden age" (Chazoule 2004) is imminent.

I have described my purposive sampling methods in Chapter 1. With help from Pierre Sourzat, we carefully selected participants who were knowledge about the history of agriculture or trufficulture in Lot. With such a nonrandom sample, when I calculate means, medians and standard deviations, I am doing so to emphasize interesting variation in this sample. These basic statistics only reflect this nonrandom sample. Thus, they are not generalizable to the broader population of Lot's or French trufficulteurs.

I report my results along the lines of the survey structure, with sections based on ecology, economy and a final section that includes causes of the decline, current organizations and the future of trufficulture. I methodically report the results of the survey questionnaire, which I have included in the appendix. For responses that elicited a greater diversity of opinion, I quote individual trufficulteurs, trying to mimic of kind of conversation or debate between these trufficulteurs. To retain their anonymity, I have assigned them a number, which I will use in all citations.

\section{J. General Description of Trufficulteurs}


Of the 42 trufficulteurs that I surveyed, $86 \%$ percent were men. Their average age was 63 years with an age range from 25 to 86-years-old. All participants were white. While some had moved away for work and returned, $82 \%$ were born in Lot. The others had either stayed or returned in their retirement years. While 18 participants said that they had been involved in trufficulture their entire lives, for those who listed a specific year when they become trufficulteurs, the average year was 1988, with the newest truffières planted in 1995. Therefore, all those interviewed managed truffières that were in their usual productive years. Only $38 \%$ percent had been or were still active farmers, while the others were or had been salespeople, functionaries, teachers and railroad workers who become trufficulteurs as a side project. The most common reason that they become trufficulteurs was a "passion" for the truffle, while carrying on their "family tradition" as well as earning "complementary" revenue were also frequent responses.

\section{K. Truffle Ecology}

Small truffières dominate as the median size was four hectares, the mean was 6.11, the sample standard deviation 6.77. The range was from .7 ha to 30 ha. These trufficulteurs together had 256.75 ha of truffières created from forest plantations. Few had "restored" or "renovated" former truffières. Instead, these trufficulteurs overwhelmingly focused on creating new truffières. The median age when these plantations started producing was 9.50 years, the mean was 10.65 , with a standard deviation 6.05 and the range was between 5 and 25 years. Even though many of these truffières were in their prime productive years, the median number of productive trees was $15 \%$, the mean was $20 \%$ with a standard deviation of 21.98 . Therefore, on average, only one in five planted saplings would ever produce a single truffle in its lifetime. Here 
we can see that problems of failed inoculation and contamination are widespread. A handful of trufficulteurs stated that they had achieved near 100\% production because they continuously removed unproductive trees and replanted. These high percentages greatly skewed the data and produced high standard deviations.

Before creating their truffière, $42 \%$ of these lands were occupied by grapevines, $26 \%$ had been under cereals, $19 \%$ were in fallows and 13\% had been forests. Most trufficulteurs argue that lands formerly dedicated to grapevines, lavender and sunchokes all played a positive role in preparing the soil and in minimizing competitive fungi. Therefore, the fact that so many of these lands had been planted in grapevines seems to bode well for truffle production. A few trufficulteurs still produced wine, as their lands fell within the Cahors AOC.

As for the species of trees planted, 90\% planted Quercus pubescens, $74 \%$ planted Quercus ilex with most planting a mixture of the two. While oaks dominate, $36 \%$ of trufficulteurs had planted as least some common hazel (Corylus avellana). Many trufficulteurs said they chose Quercus pubescens because it is the 'native' tree of Lot and was historically planted by their families (Trufficulteur \#4, personal communication, 08/05/2015). They argued that the Quercus ilex often produced sooner than Q. pubescens, though it often did not produce as long (Trufficulteur \#19, personal communication, 07/04/2014). Hazels were supposed to produce more precociously, but many trufficulteurs who planted them said that they had problems with fungal contamination from other truffle species like Tuber brumale. Few continued to plant hazels because of these issues with fungal contamination (Trufficulteur \#28, personal communication, $08 / 12 / 14)$. 
Only $10 \%$ had not planted inoculated plants. Despite their wide adoption, only $40 \%$ of trufficulteurs said that inoculated plants were superior to those grown on site by trufficulteurs. In large part because many trufficulteurs began after the development of inoculated plants, $31 \%$ were uncertain if inoculated plants were superior, while $19 \%$ were certain that they were not as good as homemade plants. Those who did not prefer inoculated plants argued that homemade plants used to have high rates of inoculation in part because trained pigs would help distribute spores and people would "seed" their truffières to aid in inoculation (Trufficulteur \#19, personal communication, 07/04/2014). Those in favor of inoculated plants argued that "conditions have changed" and only inoculated plants work now (Trufficulteur \# 11, personal communication, 07/10/2015). Some of those who were unsure emphasized that the land where they planted is a more important predictor of success. Others stated that plant quality varies between commercial nurseries, while inoculated plants have by no means taken the chance out of trufficulture and that they are not in and of themselves sufficient to ensure production (Trufficulteur \#10, personal communication, 08/07/2015).

Considering the importance that the land plays, $48 \%$ of trufficulteurs had their soil analyzed before creating their plantations. Based on these analyses, $45 \%$ amended their soils, often by adding limestone to modify the soil $\mathrm{pH}$. Many others crushed larger rocks in the soil. Many of those who conducted these soil analyses did so because it was a necessary requirement to receive government subsidies. Those trufficulteurs who did not conduct soil analyses or modify soil conditions said that as their commune had once produced truffles "the land is good here" (Trufficulteur \#6, personal communication, 
$07 / 30 / 15$. They felt no need to change relations. In many cases, their family had long produced truffles on those lands.

Despite the sense of having "good land", half of all trufficulteurs expressed that they had problems with fungal competition, especially with $T$. brumale, which produces fruiting bodies at the same time as T. melanosporum, while fewer perceived problems with T. aestivum, a truffle which produces fruiting bodies in the late summer. In some cases, they said that these other truffles out compete T. melanosporum by forming exclusive relations with host trees (Trufficulteur \#11, personal communication, 07/10/15). One trufficulteur said it is mainly the edges of their plantation near mature forests that experience problems with fungal competition (Trufficulteur \#1, personal communication, 07/19/16). Another argued that frequent fungal contamination was a clear sign that one was not working the land properly, while another said that trained truffle-hunting pigs minimize contamination (Trufficulteur \#22, personal communication, 07/17/14). Some blamed contamination on poor commercial nursery practices saying that contamination was less frequent in homemade plants (Trufficulteur \#15, personal communication, 07/16/15). A few trufficulteurs believed competition was so fierce that they would uproot any trees that produced T. brumale (Trufficulteur \#20, personal communication, 07/04/14). Others argued that these different fungi can "coexist" (Trufficulteur \#28, personal communication, 08/12/14). Others did not find T. brumale's presence wholly unwelcome as they could still sell them in regional markets for 200-300 Euros/kilo, which was about a third of T. melanosporum Trufficulteur \#13, personal communication, 07/08/15). Fewer were enthusiastic about T. aestivum, even though the commune of Limogne holds a weekly summer market in honor of that truffle. Many do not harvest it. 
One trufficulteur defiantly called it a "bullshit" truffle (Trufficulteur \#13, personal communication, 07/08/2015).

To further compound ecological uncertainties for trufficulteurs, $86 \%$ recognized that anthropogenic climate change was taking place. Of those recognizing anthropogenic climate change, $89 \%$ believe that it has impacted trufficulture. The most frequently cited impacts were the increasing frequency and severity of summer droughts (Trufficulteur \#1, personal communication, 07/19/2016). As one trufficulteur simply stated: "when's there are rains there are truffles," (Trufficulteur \#9, personal communication, 07/30/15), while another said: "it's the droughts that destroy truffles," (Trufficulteur \# 11, personal communication, 07/10/2015). In the kind of anthropomorphic language often used to describe the truffle (which is a feminine noun in French) a trufficulteur said: "the truffle is a kind and beautiful woman. She loves kind treatment, a favorable climate, which in general this region has," (Trufficulteur \#32, personal communication, 08/14/14). For many trufficulteurs the climate had turned against the truffle.

Some argued that they had only one good year for the truffle every ten years, while they used to have one bad year every ten years. They also said that these droughts have been equally difficult for farmers of other crops and not only trufficulteurs (Trufficulteur \#10, personal communication, 08/07/2015). One trufficulteur said that crops like beets and tobacco now required irrigation whereas they had not before (Trufficulteur \#7, personal communication, 07/31/2015). Others noticed the seasons being less marked and phenological changes like the "cicadas were singing earlier," (Trufficulteur \#28, personal communication, 08/12/14). 
Trufficulteurs adapted in various ways to the perceived negative impacts of anthropogenic climate change on truffle production. Many have felt the need to install irrigation systems (Trufficulteur \#4, personal communication, 08/05/2015). Others would place pruned branches on the ground to retain soil humidity, while others scattered leaves on the ground to create the same effects (Trufficulteur \#42, personal communication, 01/07/15; Trufficulteur \#22, personal communication, 07/17/14). One interviewee mentioned how they grandmother had regularly pruned branches that they would place on the ground as insulation, before sheep would eat them (Trufficulteur \#16, personal communication, 07/16/2015).

Yet many who feared that droughts due to anthropogenic climate change were negatively affecting truffle yields did not feel that the increased costs of irrigation were worth potential increases in yields. Along these lines, one trufficulteur argued: "why invest in a crop that is so difficult and unpredictable?" (Trufficulteur \#5, personal communication, 08/05/15). Another said: "I'm retired now and will not invest in irrigation only to harvest a few truffles," (Trufficulteur \#10, personal communication, 08/07/15). Even if irrigation was becoming necessary, they were not ready to make the investments and would risk climate variability.

Still others argued that while irrigation increases production in the short-term it can decrease the productive life of a truffières in the long-term. Another trufficulteur said that trufficulteurs have aggressively irrigated in Dordogne and that truffles from their land now taste like "potatoes" because of over-irrigation. He added that "you must let the truffle do its thing," (Trufficulteur \#32, personal communication, 08/14/14). Similarly, one trufficulteur said that irrigation would not end the variability of truffle yields and that 
"trufficulture was not an exact science," (Trufficulteur \#31, personal communication, 08/13/14). Agreeing that trufficulteur was not an exact science, they wondered "Why invest in a crop that's so difficult and unpredictable?" (Trufficulteur \#5, personal communication, 08/05/2015). Despite these disagreements over climate change mitigation, one trufficulteur surmised the discussion well in saying, "Climate change will play a very important role in the future of truffle farming," (Trufficulteur \#6, personal communication, 07/30/2015).

Yet low rates of productivity, fungal contamination and anthropogenic climate change are not the only sources of uncertainty in truffle ecology. Trufficulteurs describe how they have had to install wire baskets around individual trees because deer rut against young trees and can destroy them in the process. The greatest problem though has been wild boars who will tear through a plantation, destroying trees and upturning the soil. One trufficulteur mentioned how a wild boar once destroyed 10-15\% of his trees. Even electric fences are not entirely boar proof as once a wild boar charged through the electric fence to "decapitate" young trees (Trufficulteur \#7, personal communication, 07/31/15).

Many trufficulteurs tied the increases of damages by boars to changing landscapes and increasingly dense and closed canopy forests. Agricultural abandonment helped create favorable boar habitat. They argue that deer and boar were much less of a problem in the past. Now many have either installed electric or chain-link fences to protect their truffières (Trufficulteur \#3, personal communication, 08/06/15). A few dissenting voices argue that all species played a role in truffle landscapes and that the wild boar was also responsible for disseminating truffle spores (Trufficulteur \#12, personal communication, 
07/16/15). Otherwise, the majority of trufficulteurs hoped to keep deer and boars out of their truffières as they could dramatically alter productivity.

Humans can negatively impact the profitability of a truffière through truffle theft. While few suggest that it is a grave and sustained concern, $36 \%$ of trufficulteurs said that they believe they have experienced at least some truffle theft at least once, though no one reported frequent and ongoing theft. To keep thieves out of their truffières, some have installed high fences, which would also protect a truffière from deer and wild boars. One trufficulteur has even installed a motion-sensor camera to watch over the plantation. More commonly people will regularly patrol their truffières with a dog to scare away potential thieves and make it clear that someone was still tending the truffière. Yet truffle thieves had comparatively limited impacts compared to other actants. While many of these actor-networks have played a role in truffle declines, in the next section I asked survey interviewees to explain their understanding of truffle declines in Lot. While, I explored these declines through archival research in the previous chapter, I repot these results to show diversity of opinion about declines among active trufficulteurs.

\section{The Decline of Truffle Production in Lot}

The most common reason for this decline was the rural exodus and declining number of active farmers in Lot. One trufficulteur argued that these changes had a strong geographical component. As more farmers bought tractors and other agricultural machinery they moved away from the steep hillsides (coteaux) where they had once had their truffières (Trufficulteur \#1, personal communication, 07/19/16). Farmers restricted their work to flatter and more fertile land, the exact type of land that is not suitable for truffle production. As they could work most lands with a tractor, no one wanted to work 
their truffière by hand, which had long been the local custom. For many, large farm machinery is not suitable to trufficulture in Lot as it can compact the soil and damage trees (Trufficulteur \#2, personal communication, 08/06/15).

One trufficulteur mourned that decades earlier the commune of Aujols had 30-40 active farmers and now there was not a single person who worked as a full-time farmer. The commune once had 1500 ha of grapevines and now had virtually none. As agriculture grew ever more specialized after its "modernization", viticulture shifted almost exclusively to the area that would become the Cahors AOC. Despite a historic high reputation for the commune's wines in Aujols, local politicians failed to have them included in the Cahors AOC. Without an AOC, they had little chance to compete in a difficult wine market. Remaining farmers relied on truffles, for a time (Trufficulteur \#5, personal communication, 08/05/15).

The story of Aujols is generalizable for many of Lot's truffle-producing areas as 93\% of respondents felt that there were fewer and fewer farmers in Lot. Many trufficulteurs blamed the declines of Lot's agricultural population on global economic competition and the fact that phylloxera decimated its economy in the 1880s and viticulture never fully recovered, even if trufficulture led to a temporary prosperity in former viticultural communes like Cuzance (Trufficulteur \#28, personal communication, 08/12/14; Trufficulteur \#35, personal communication, 08/14/14).

During agricultural "modernization", farmers focused on a single crop and forgot about trufficulture (Trufficulteur \#10, personal communication, 08/07/15). A deleterious form of specialization in agriculture was that trufficulteur stopped moving small flocks of sheep through their truffières, which had maintained favorable milieus. As attention 
shifted away from more marginal agricultural lands because of mechanization and specialization there was a generally declining interest in "natural" truffières Trufficulteur \#15, personal communication, 07/16/15). Looking back fondly on the days of polyculture agriculture in Lot, one trufficulteur said that there are no more "peasants" (paysans) in Lot (Trufficulteur \#28, personal communication, 08/12/14).

In addition to this loss of peasants from the rural exodus, agricultural mechanization and specialization, others added that many farmers and trufficulteurs were lost in WWI and WWII as well (Trufficulteur \#3, personal communication, 08/06/15). Some argued that much knowledge went with these farmers who were killed in the wars (Trufficulteur \#6, personal communication, 07/30/15). Others argued that these wars had other far-reaching effects: "it was the flight of peasants' children. Soldiers learned another mode of existence," (Trufficulteur \#28, personal communication, 08/12/14).

As attention shifted away from trufficulture, landscapes become increasingly forested and dominated by closed canopy forests. The lack of local fuelwood consumption exacerbated these trends. As forest canopies closed and the ground went unworked, truffle production declined. The lack of maintenance of truffières led to invasions by leaf-eating caterpillars that killed oak trees (Trufficulteur \#3, personal communication, 08/06/15; Trufficulteur \# 11, personal communication, 07/10/2015). One trufficulteur mentioned a devastating freeze in 1956 that killed many 'truffle' trees (Trufficulteur \#25, personal communication, 07/18/14). As previously discussed the same conditions helped to increase deer and wild boar, which affect truffières in primarily negative ways. Many trufficulteurs argued that anthropogenic climate change has further made truffle production more unpredictable. 
During the period when this unpredictability was becoming more evident, "there was a change in mentalities among farmers that was prejudicial to the truffle as more people only knew the period of its decline," Trufficulteur \#7, personal communication, 07/31/15). At the same time people demanded nearly "assured production" to be interested in trufficulture (Trufficulteur \#21, personal communication, 07/16/14). One trufficulteur complained that "people don't want to work, and they are not patient. They want to harvest truffles two years later," (Trufficulteur \#32, personal communication, 08/14/14). Similarly, another trufficulteur said: "An entire generation forget how to work with the truffle. There was once a tonne of truffles at the market, but now they have almost disappeared," (Trufficulteur \#39, personal communication, 01/25/15). For another trufficulteur in the past people were not so "selfish" because they created plantations not for themselves but even more to benefit their children and grandchildren, (Trufficulteur \#40, personal communication, 01/09/15).

Many argued that during the second half of the 20th century fewer people were creating new truffières (Trufficulteur \#25, personal communication, 07/18/14). The few new truffières were small as farmers reserved their labor and better land for more predictable crops. One trufficulteur lamented that there has been in Lot "the absence of courage of the people to uproot old trees and replant. There is a lack of passion," (Trufficulteur \#22, personal communication, 07/17/14). While "assured production" seemed far off and fewer people were reinvesting in the future of trufficulture, (Trufficulteur \#7, personal communication, 07/31/15). One trufficulteur said that they many stopped even bringing their truffles to market and mainly kept them back for household consumption, (Trufficulteur \#12, personal communication, 07/16/15). 
Even with declines in trufficulture, much knowledge was shared. Roughly $74 \%$ of trufficulteurs learned from their own or their spouse's families. One trufficulteur mentioned how his family's truffle yields had been instructive: “They had a neighbor who planted five hectares of truffières. They would go every week with their pig. They harvested so many truffles that they would return with a horse later in the afternoon to carry back the sacks of truffles that they had collected that day," (Trufficulteur \#7, personal communication, 07/31/15).

Many others learned either from talking to local farmers or from taking a course at the local agricultural extension school in Montat. In one case, a trufficulteur caught the "virus" of the truffle when he noticed that a "natural" 'truffle' tree produced quality truffles and decided to plant more, (Trufficulteur \#40, personal communication, 01/09/15) Another said that they had visited the Lalbenque truffle market and it had "fascinated" them. They then began to ask for tips around Lalbenque (Trufficulteur \#33, personal communication, 07/16/14).

Even though many had learned trufficulture from their families, only $38 \%$ said that someone had shared knowledge openly. Some said that older generations "kept their secrets," (Trufficulteur \#1, personal communication, 07/19/16). Such "secrets" may have included the location of productive 'spontaneous' truffières. Others said there was a "mentality of secrecy in the countryside," (Trufficulteur \#6, personal communication, 07/30/15) One trufficulteur even said that to keep their secrets, neighboring farmers advised him to do the opposite of what he should have done (Trufficulteur \#41, personal communication, 01/08/15). Others said that they were not "encouraged" to become 
trufficulteurs and that their generation "were victims of that mentality," as few had replanted (Trufficulteur \#3, personal communication, 08/06/15).

Still others argue that there was not even a whole lot of knowledge to share in the first place. One trufficulteur argued that "It's not that complicated. Almost all mushrooms are the same," (Trufficulteur \#10, personal communication, 08/07/15) while another said, "it's nature that makes the truffle," (Trufficulteur \#13, personal communication, 07/08/15). Going even further, one trufficulteur said that "the savoir faire of our elders is of little value because of climate change and improvements in plants," (Trufficulteur \#18, personal communication, 07/01/14).

Another said that there were "a lot of superstitions about the moon" and its role in cultivation cycles and much advice was "contradictory" (Trufficulteur \#23, personal communication, (07/17/14). Others put more faith in managing a truffière, especially pruning along with moon cycles (Trufficulteur \#36, personal communication, 01/24/15). Another said sharing this knowledge was difficult because it was empirical and no explanation was given as to why they were doing what they were doing (Trufficulteur \#24, personal communication, 07/18/14). Some emphasized the mysterious nature of trufficulture: "The knowledge of our ancestors, one will never know...There is no recipe for producing a truffle," (Trufficulteur \#29, personal communication, 08/13/14).

M. The Political Economy of the Truffle

Despite suspicions about the applicability of historic techniques for today's trufficulteurs, they do not uniformly embrace all contemporary agricultural innovations. Half of all trufficulteurs note that farmers in their vicinity use argo-chemicals. Overall $38 \%$ of trufficulteurs argue that agro-chemicals can have a negative impact on truffle 
production. One trufficulteur believes that some of the chemicals used on cereals may harm truffle trees, while other says that "pollution in general" may hurt the truffle (Trufficulteur \#39, personal communication, 01/25/15). Others argue that agro-chemicals are important in trufficulture and that "serious trufficulteurs use herbicide" (Trufficulteur \#33, personal communication, 07/16/14). One noted that some "intensive" trufficulteurs in Australia use them with success (Trufficulteur \#20, personal communication, 07/04/14). Overall trufficulteurs were far more concerned with declining agricultural populations, climate change and wild boars than with the nearby application of pesticides. Public policies have influenced these "changes in mentality" as well. They have changed Lot's agricultural population. They can impact short-time as well as long-term truffière management. One policy encourages the retirement of farmers over the age of 62 and the transfer of their land to comparatively younger farmers (l'indemnité viagère de départ IVD). Trufficulteurs argued this program has had varied effects. If a person does not have a successor, then they must give up their lands and all their truffières beyond two hectares of land to receive payments.

Also, if one is going to enter the program without a successor, then the program can discourage people from creating or expanding plantations as they reach retirement age (Trufficulteur \#25, personal communication, 07/18/14). Others say that it is exactly this right to keep two hectares of land that allows them to remain trufficulteurs even after retirement (Trufficulteur \#37, personal communication, 01/21/14). One trufficulteur said this provision is especially important as "it's retired people that sell the truffle," (Trufficulteur \#10, personal communication, 08/07/15) Another said retirement allows one to truly exercise their "passion for the truffle," (Trufficulteur \#22, personal 
communication, 07/17/14.) These IVD payments then may help them invest into their truffières if they have a successor, but limits further investments if they do not (Trufficulteur \#18, personal communication, 07/01/14).

Only $45 \%$ of trufficulteurs plan to enlarge their truffière soon. The high median age combined with the IVD means that some said that they were "too old" to replant (Trufficulteur \#4, personal communication, 08/05/15). For those without a successor, it is unlikely that they would replant. One said that since they know that they should install an irrigation system and fencing that they are less likely to replant (Trufficulteur \#8, personal communication, 07/30/15). Similarly, one trufficulteur said that as labor costs are high and production is uncertain, there is not much financial incentive to enlarge his truffière (Trufficulteur \#17, personal communication, 07/16/15).

Another relevant policy for Lot's farmers and trufficulteurs is the European Union's Common Agricultural Policy (CAP), which offers per hectare payments to farmers. Until 2016, trufficulteur was not considered to be an applicable "culture" and so trufficulteurs could not apply for these subsidies. One trufficulteur said that the truffle nor the "peasant world" that it existed in recognized by the CAP (Trufficulteur \#32, personal communication, 08/14/14). Prior to these rule changes to include the truffle as a “culture" worthy of subsidies, 55\% of trufficulteurs argued that these policies "penalized" trufficulteurs largely because these subsidies shifted farm labor away from trufficulture. One trufficulteur argued that it favors those "cultures" that produce quicker profits, while "trufficulture is a culture of patience," (Trufficulteur \#38, personal communication, 01/21/15). Another said that the supportive CAP payments for trufficulture could greatly reinforce this "patience" as people waited the four plus years 
for their truffière to become productive. One farmer even said that his family cut down 35 hectares of old truffières to plant pastures because of CAP payments (Trufficulteur \#37, personal communication, 01/21/15). In arguing for trufficulture to be included in the CAP, one trufficulteur said that the truffle "is a culture that people want."

Yet the PAC is not the only available source of subsidies. Both the départemental and regional government offer subsidies, which 55\% of surveyed trufficulteurs found potentially helpful. For those in favor of subsidies most people argued that they would help offset the cost of buying trees and creating a plantation or maintaining existing plantations, while some recognized the need for subsidies to cover the cost of installing irrigation systems and fencing (Trufficulteur \#4, personal communication, 08/05/15). Only $19 \%$ of people found current subsidy levels to be sufficient. Also, only $29 \%$ of trufficulteurs received subsidies. Some said that they were worried about having their production taxed if they applied, or as one trufficulteur colorfully expressed it: they could become "a prisoner in a bureaucratic system" if they requested subsidies (Trufficulteur \#32, personal communication, 08/14/14).

Others said that subsidies would be more useful to "renovate" former truffières, while another said that subsidies have not greatly increased production because many planted on unsuitable lands (Trufficulteur \#8, personal communication, 07/30/15). In this case, subsidies benefit commercial nurseries more than trufficulteurs (Trufficulteur \#30, personal communication, 08/13/14). Others were critical of the fact that the Spanish government offered far more generous subsidies to its trufficulteurs (Trufficulteur \#20, personal communication, 07/04/14). 
The rise in Spanish production has become worrisome for trufficulteurs in Lot. Many feel Lot's truffles should be 'defended'. In fact, 93\% of trufficulteurs believe that truffles produced in Lot should benefit from some form of a recognized labelling scheme in part to differentiate it from lower priced Spanish truffles. For some, would help to "preserve the image of the truffle" in Lot (Trufficulteur \#1, personal communication, 07/19/16), while others say it is important to restrict markets to only T. melanosporum and avoid fraud. Some hoped the label would "show off the quality" (Trufficulteur \#4, personal communication, 08/05/15 of truffles produced around Lalbenque, which has a “terroir and zone to protect," (Trufficulteur \#7, personal communication, 07/31/15).

Others highlighted the greatness of Lalbenque's truffles as something to 'defend': "The Lalbenque truffle is the best in the world. I have friends who live all over and they all think that this is the best truffle," (Trufficulteur \#15, personal communication, 07/16/15). Yet many noted how difficult it has been for the Lalbenque's Trufficulteur Syndicate to gain an appellation d'origine contrôlée (AOC) when its yields are so varied from year to year. As one trufficulteur said: "it's production that we lack," (Trufficulteur \#34, personal communication, 08/14/14).

Others noted that the truffle is known through the world as the Périgord truffle and that overturning this long-standing informal appellation would be incredibly difficult (Trufficulteur \#29, personal communication, 08/13/14.) Others argue that even more important than labels, the syndicate needs to better control the quality of truffles sold in Lot's markets like Lalbenque: "Sometimes people have a basket with four beautiful truffles and the rest are shit...The market is not controlled...They sell some shitty truffles there," Trufficulteur \#32, personal communication, 08/14/14. 
Different trufficulteurs argue this effect of terroir has a variety of causes. One trufficulteur argues that "the influence of the land is important. Truffles from red earth are finer. Truffles from Lalbenque are sold quickly and retain their freshness," (Trufficulteur \#39, personal communication, 01/25/15). Others argue that the "perfume" of individual truffles is less nuanced if harvested from Quercus ilex and better from $Q$. pubescens (Trufficulteur \#22, personal communication, 07/17/14). Some even argue that their clients ask explicitly for "wild" truffles harvested from "natural" truffières as they believe their "perfume" is more complex (Trufficulteur \#2, personal communication, 08/06/15). Others singled out certain communes as having unique truffle terroirs like Cremps, Aujols and Laburgade (Trufficulteur \#25, personal communication, 07/18/14). Still others argue that T. melanosporum truffles are the same everywhere, including those from Spain, and that the most important aspect is that they are harvested and sold at their peak freshness (Trufficulteur \#23, personal communication, 07/17/14).

What is interesting about the questions surrounding terroir and a labelling scheme is that only one trufficulteur surveyed makes a living primarily from trufficulture. Others earn a fair portion of complementary revenue from truffles, while for many it is a hobby that provides occasional funds. One trufficulteur earning a modest stream of complementary revenue said that trufficulture "is too unpredictable to do it full-time" (Trufficulteur \#7, personal communication, 07/31/15). One respondent in the last category said that they became a trufficulteur largely "for the pleasure of having planted trees, watching them grow and to have the opportunity to work with his dog," (Trufficulteur \#6, personal communication, 07/30/15) In fact, while some earned their 
principal source of income from agriculture, most commonly they live off retirement pensions. Therefore, trufficulture was a pastime during retirement for most.

Yet, even if the truffle sales did not provide their main income source, two trufficulteurs operated rural bed and breakfasts (gîtes) that offered truffle tasting menus as well as simulated truffle hunts with a trained dog. While these two trufficulteurs earned far more money from truffle-related tourism, $81 \%$ of those surveyed said that tourists did not strongly contribute to the local truffle economy, even if tourists sometimes ate in restaurants and stayed in local hotels (Trufficulteur \#2, personal communication, 08/06/15).

Many trufficulteurs seemed disappointed that they perceived that tourists mainly came to truffle markets to take pictures and not to buy truffles. One trufficulteur was exasperated when they overheard a tourist's shocked response to truffle prices by saying: “This isn’t Dior!” (Trufficulteur \#3, personal communication, 08/06/15). Another tourist was overheard saying: "I won't be buying those. They look like balls of dirt," (Trufficulteur \#7, personal communication, 07/31/15). Those most dismissive of tourism used the word "folklore" to refer to the tourist spectacle surrounding the truffle. One trufficulteur argued that this folklore "isn't worth anything" and that "it is not tourism that will save the truffle," (Trufficulteur \#10, personal communication, 08/07/15).

Organizations in Lot, like the syndicates and associations of trufficulteurs in Limogne, Martel and Lalbenque, which also connect to groups at the départemental, regional and national levels as well as the agricultural school and extension office at $L e$ lycée professionnel Agricole et Viticole de Cahors - Le Montat (The Profession Agricultural and Viticultural High School of Cahors-Le Montat) are trying both to 
promote the "folklore" of the truffle while also trying to increase its production and ensure it a place in the global truffle market.

Three-quarters of respondents belonged to at least one syndicate or association of trufficulteurs, while many others had been members previously. While some had joined only two years prior, others had been members for 40 years. Some interviewed had served in important positions of leadership. The majority, $86 \%$, said that membership is important for the overall progress of trufficulture. Many people see the role of syndicates and associations as a means of exchanging and sharing information. Many felt that they could "deepen their knowledge" through exchange (Trufficulteur \#34, personal communication, 08/14/14). Others pressed for a more political role and less social role for syndicates and associations: "I'm not passionate about getting together for dinners...the syndicate should be made up of people truly passionate about the truffle. Right now, it is not representative. They should be working on broader territorial development," (Trufficulteur \#10, personal communication, 08/07/15).

Another means of sharing information is a magazine published by truffle extension agents at the Agricultural High School in Le Montat, which is written in a journalistic style that disseminates recent scientific findings to trufficulteurs. Seventy-six percent of trufficulteurs received this magazine, Le Trufficulteur des Causses du Quercy. This magazine is published by the former head of truffle experimentation at the agricultural extension school at Le Montat, where a few respondents took courses on trufficulture. The school has high local visibility as $95 \%$ of trufficulteurs knew generally about the work done there, while $85 \%$ had received assistance from technicians at Le Montat. Another 67\% hoped for further technical assistance. 
Respondents wanted technicians at Le Montat to decrease the unpredictable and "aleatory" nature of truffle production in Lot (Trufficulteur \#1, personal communication, 07/19/16). Other priorities included making production last longer (Trufficulteur \#21, personal communication, 07/16/14), learning how to better regulate timing and dosages for irrigation that would better favor T. melanosporum (Trufficulteur \#23, personal communication, 07/17/14). As one trufficulture said: "The problem of water is a problem for peasants," (Trufficulteur \#37, personal communication, 01/21/15). Many hoped to learn themselves or that nurseries would learn to produce better plants "inoculated" with local acorns and truffles that have higher rates of colonization and lower rates of contamination (Trufficulteur \#24, personal communication, 07/18/14). Beyond the creation of new plantations, others wanted to know about how to "renovate" or "rehabilitate" a truffière (Trufficulteur \#18, personal communication, 07/01/14).

Outside of more technical questions, some hoped that extension agents at le Montat would motivate more young farmers and viticulturists to become trufficulteurs (Trufficulteur \#14, personal communication, 07/10/15). Others hoped that Le Montat would focus less on the "image" or folklore of the truffle and more on promoting farmers to create truffières (Trufficulteur \#10, personal communication, 08/07/15).

\section{N. Trufficulteurs' Prognostications}

To finish the interviews, I asked respondents how they saw the future of trufficulture and the truffle in Lot. Opinions varied widely. One trufficulteur said: "After many years of not planting, people have started to plant and are creating a more 'dynamic' trufficulture,” (Trufficulteur \#3, personal communication, 08/06/15).

Optimistically and resolutely, one trufficulteur said: "We cannot merely follow. We must 
believe thing can change but reality confronts us. Things must change," (Trufficulteur \#27, personal communication, 08/12/14).

Yet others argued that there was of work to be done, though on trufficulteur was not certain that it would happen: "I see a dark future for the truffle because there is a lack of able people to produce it. You need to convince the people. They will often abandon the truffle after subsidies end," (Trufficulteur \#32, personal communication, 08/14/14). Beyond the fact that people often did not put in the necessary work, nonhumans seemed less cooperative as well: "The weather is no longer suitable for the truffle. Production has lowered for other truffles as well. The climate has changed and it is not favorable or at least less favorable for the truffle. You once found truffles in former fields of sunchokes, alongside woods and in old hay fields...Meanwhile, in Spain production on a single farm can reach 200kg," (Trufficulteur \#36, personal communication, 01/24/15).

Beyond these climatic difficulties, others argued that landscape-level change was necessary to maintain if not increase truffle production in Lot: "There needs to be largescale land clearing. My grandfather and father both talked about areas that were once farmed that are now forested or filled with bushes. Lands could be cleared with pastoralism. In other times, sheep would help clean the forest understory," (Trufficulteur \#7, personal communication, 07/31/15). Trufficulture had a broad role to play in Lot's landscapes, even if it was being ignored: "The agriculture crisis continues to be catastrophic for the region. Trufficulture can play a role in keeping the land worked," (Trufficulteur \#10, personal communication, 08/07/15). Another trufficulteur talked of the link between truffles and landscapes that "it is a mushroom that is absolutely 
indispensable to the biodiversity of our causses...Without mushrooms there is no life on earth," (Trufficulteur \#28, personal communication, 08/12/14).

Others felt that trufficulture and agriculture were in a precarious position in Lot: "If no one makes a move soon, we're headed for catastrophe. It is the syndicate, the politicians and the chamber of agriculture who should make a move," (Trufficulteur \#10, personal communication, 08/07/15). Another trufficulteur argued that "policies need to begin to favor agriculture and allow people to keep land to relaunch production so that people can save a few hectares when they retire. We need to conserve land for trufficulture," (Trufficulteur \#19, personal communication, 07/04/14).

Yet some argue that policies have not focused on the multiple roles the truffle can play. One trufficulteur argued that too many officials "are only happy in promoting the folklore of the truffle," (Trufficulteur \#10, personal communication, 08/07/15) Another trufficulteur against "folklore" said that "folklore does not serve the truffle. We need to produce more truffles and talk about the truffle less. We need to educate people on how to consume the truffle. It's exciting to think about how to improve production," (Trufficulteur \#26, personal communication, 08/12/14)

In other cases, trufficulteurs were more worried about how the truffle circulated in local, national and global markets. As one trufficulteur said, "markets must be better organized and sellers to need to better negotiate to increase sales. People in Lalbenque last year (2014-2015) sold only 50 of 250 kilos. There are not the wholesale buyers like before," (Trufficulteur \#3, personal communication, 08/06/15). Another trufficulteur argued that the local truffle market needed major readjustment: "It is necessary to create an organization that will commercialize, transform and sell local truffles that are in the 
process of decline. The Lalbenque truffle market cannot "absorb" any more truffles. Conservers do not shop there anymore," (Trufficulteur \#42, personal communication, 01/07/15). Another said that there needs to be continued work in earning a food label backed by the European Union. Conversely, one trufficulteur said that "the truffle should remain a product of the elite. The truffle should not become an ordinary product," (Trufficulteur \#31, personal communication, 08/13/2014).

\section{O. Discussion}

In this chapter I have juxtaposed the recent scientific findings on the truffles' biology, ecological, chemistry and genetics with how these findings are accepted or ignored by Lot's trufficulteurs. Instead of the wholesale or uniform adaptation of a kind of highly capitalized "modern" trufficulture, I have highlighted how differences in willingness to invest, age and farm succession, ecological understandings and motivations to become a trufficulture influence trufficulteur's practices.

These different variables, among others, produce significant "fluidity" in how trufficulture is practiced. Whereas professional farmers may have had to adopt new technologies and the debt that came with them, few trufficulteurs surveyed depend much on revenue from truffles. Therefore, they can carefully select what implements and practices fit with their interests. Different policies from payments that encourage farmer retirement and different subsidies further influence these decisions. As farmers without successors can retain roughly two hectares, they can receive payments while remaining trufficulteurs but cannot maintain a large truffière. Support for subsidies among interviewees was far lower than expected. Again, as most saw trufficulteur as a hobby or something they were passionate about, economic concerns were not primary. 
Yet for the few surveyed trufficulteurs who have taken on most or all the "modern" trufficulture actor-network, significant challenges remain. Best practices are under significant flux. I have highlighted the complications resulting from the fact that significant production rarely begins before 10 years after planting, with rapidly changing understandings of truffle actor-networks. There is a disconnect between the trufficulture being practiced in Lot and the ever-changing array of truffle ontologies proposed by scientists. These long production times compared with rapid scientific "cycles of accumulation" (Latour 1987) then complicate how quickly the modernization of trufficulture can proceed, or even if it is at all possible.

Temporality in various ways then plays an important role in these actor-networks. Many were practicing trufficulture because an ancestor had done so. They attempt to maintain this heritage. Others looked more toward the future. Many trufficulteurs made decisions based on if they had a successor. The high median age of those interviewed and selected through my purposive sampling strategies further influenced such decisions. In some cases, trufficulteurs had children, but these children lived in distant cities and would likely not return to Lot to maintain a truffière and harvest truffles. They recognized that trufficulteurs had long planted for the next generation as well as their own. In shorter timeframes, if one did not have a successor, they also would not only be uneasy about expanding their truffière, some did not want to invest in irrigation systems to help mitigate the negative effects of climate change or install fencing to protect against deer and wild boar. As a successful truffière can produce 25 years, the investment may be worth it if there are people interested and able to maintain it. 
These decisions to 'modernize' or not depend on nonhumans as well. First, the fact that roughly $15 \%$ of mycorrhized plants ever produce truffles demonstrates how grave low levels of inoculation and how high rates of contamination can be. Only diligent management of collecting some form of data on tree productivity and regularly uprooting all nonproductive trees brings production to anywhere near $100 \%$. These percentages show how the "certification" of mycorrhizal plants does startlingly little to ensure truffle production (Andrés-Alpuente et al. 2014). Contamination from T. brumale and $T$. aestivum continued to be a problem for many of the trufficulteurs whom I surveyed.

Such low percentages of inoculation and frequent contamination caused some trufficulteurs to wonder if these plants were indeed even a major advancement, or if former methods may produce equal or better results. These discussions show how surprisingly unsettled of an actor-network mycorrhized plants are. Even though a vast, multinational actor-network helped produce these plants and that they have dramatically increased T. melanosporum's distribution around the world (Hall et al. 2007; Murat et al. 2015), they perform in France below even the most modest expectations (Callot 1999). Results in Lot have not led to any marked increases in production (Sourzat 2009).

Other actants have not been any more dependable. Climate change poses serious problems for trufficulteurs. While irrigation is a prerequisite for being a "modern" trufficulteur (Olivier et al. 2012), many trufficulteurs had doubts not only if such investments would pay off. They also wondered if intensive irrigation would affect the productive life of a truffière or the quality of truffles. Many felt that Le Montat should research irrigation, as dosages and timings were misunderstood. Others tried to leave pruned branches on the ground to help retain soil humidity. Despite these efforts to 
mitigate climate change, many trufficulteurs said that climate change was a driver of past declines and would affect trufficulteur in Lot in the future. For many it further destabilized actor-networks and necessitated increased investments. Those who choose not to irrigate likely face increasing variability in yields (Olivier et al. 2012).

If the negatives effects of anthropogenic climate change are a newer menace for trufficulteurs, agricultural abandonment and reforestation have been negatively truffle yields for nearly a century (Gaignebet 1923; Castelnau 1978). Interviewees talked about their communes, which once had dozens of active farmers and which now have none. Forests have expanded deer and wild boar populations have exploded, to the grave detriment of trufficulture. In other cases, farmers have been 'modernized' and specialized and so abandoned the hard to work land of the coteaux where truffles once flourished. Many of these farmers preferred the predictability of other crops and gave up on trufficulture, especially as it was not eligible for CAP payments. While farmers in Lot had long looked to truffle as a source of complementary revenue (Champagnac 2000; Meulet 1889), fewer now do. They do not have time for such an aleatory mushroom.

Lot's dilemma of declining agricultural populations save for a few highly capitalized farmers is unfortunately commonplace. Many other areas in the EU have also faced mixtures of agricultural abandonment and agricultural modernization (Kohler et al. 2014; Renwick et al. 2013). In each case, it is difficult for the remaining group of farmers, highly capitalized or not, to retain "multifunctional" landscapes that produce not only food and fiber, but also conserve biodiversity, patch-matrix landscapes and scenic beauty (McCarthy 2005). Polycultural agricultural systems, the kind that some of the interviewed trufficulteurs long to see return, were adapted to producing and maintaining 
multifunctionality (Pinto-Correia et al. 2004). Yet it is these kinds of labor-intensive landscapes which have been the most difficult to maintain (Kizos et al. 2010). Subsidies can often only do so much to either retain farmers or undo some of the most environmentally destructive 'modern' farming techniques (Kohler et al. 2014).

As broadly similar as Lot's demographic and landscape change may be to other areas, I argue that trufficulture emphasizes the gravity of these changes. One could hope that mycorrhized and certified plants would have increased per hectare productivity to the extent that fewer trufficulteurs working less land could produce more truffles. Such has not been the case (Callot 1999). In fact, many realistic per hectare estimates lag well behind those of 150 years ago (Bonnet 1869; Olivier et al. 2012). With only 1-3 tonnes per year production in Lot (Sourzat 2009), Lot has experienced declines of roughly 99\% since 1892 (Chatin 1892). While trufficulteurs did not want to divulge their individual yields, there is no way they average more than 10 kilos/ha, a fraction of yields 100 years ago. There is little wonder why trufficulture has retained such "fluidity" (De Laet and Mol 2000), when the actual results of "modern" trufficulture have been so mediocre. Progress, as promised by modernity (Tsing 2015), did not arrive for trufficulteurs. It is clear that "modern" trufficulture is an incredibly fragile and unstable actornetwork. It has in some ways an overabundance of actants without whom trufficulteurs must associate if they even can hope for dependable yields. Deer, unchecked reforestation, wild boar, competitive fungi, anthropogenic climate change and international competition all make the relaunch of trufficulture in Lot more complicated. Recent scientific findings that truffles reproduce sexually (Martin et al 2010) and that they may be an effect of associations in the "ectomycorrhizosphere" (Antony-Babu et al. 
2014) add increased uncertainties. Actants and their ontologies are under extreme flux in this actor-networks. Even Tuber melanosporum, which may be facing a loss of "virulence" (Sourzat 2009) is becoming a less dependable and understood actant.

While the investigator never wants to prematurely define the actants in an actornetwork, continuing to endlessly admit new actants will mean that stability is all but impossible. These processes, which entail the "progressive composition of a common world" (Latour 2004: 18), are not straightforward for trufficulteur. Currently this composition is going unchecked if one combines as I have done here, recent scientific work that tries to understand the 'modernization' of the truffle, and the actual outcomes. At the same time, the results reinforce that some actants are either misunderstood or going unaccounted for. One may need to open all the "black boxes" (Latour 1987) that make up "modern" trufficulture to understand why yields remain so low. Such processes are contentious and time-consuming. New scientific findings and the failures of "modern" trufficulture to increase yields instead make me believe all must be reimagined.

Furthermore, as scientific research rapidly advances, it is difficult to imagine how Lot's trufficulteurs can practically adapt these new understandings of Tuber melanosporum. They are already practicing trufficulteurs under uncertainties regarding subsidies, farm successors, wild boars, fiercely competitive fungi and a changing climate. With an older population of trufficulteurs, one may have the chance to create one truffière in their lifetimes and rarely more. This knowledge then needs to be recorded and passed on, processes which have not been successful in the past. Yet, some wonder with all the changes from the climate to mycorrhized plants if past knowledge has any value today. If change continues at today's pace, each "cycle of accumulation" of scientific 
knowledge (Latour 1987) might have to rely less and less on what has come before. Scholars have long acknowledged how mysterious the truffle was (Pradel 1914). Its mysteries at this point are only increasing.

With all that I have described in this chapter, it is hard to imagine a version of trufficulture that will work in potentially more heavily forested landscapes and with a more unpredictable climate, all while considering sexual mating types of truffles and their relations with yeasts and bacteria. Such a trufficulture does not exist in Lot nor elsewhere. A new kind of trufficulture will need to be invented. The task of inventing such a trufficulture will not be easy. If the past few decades are any indication, once it is invented it will have to undergo almost immediate modification as scientific inquiry and the material conditions of trufficulture challenge its stability.

In the next and final chapter of this dissertation, Chapter 6 , I will provide a summary of some of the key arguments of this dissertation. Additionally, I will again engage with ANT to describe the seeming impasse that trufficulteur in Lot finds itself today and how trufficulteurs may be able to navigate their way out. I engage in depth with Latour's ideas of the "modern" and "nonmodern" to describe the kinds of ambitious goals that I believe are necessary if truffle yields will ever rise that anything even approximating that of 100 years ago. My recommendations are no doubt difficult to implement, but the practice of trufficulteur today in Lot is difficult as well. With today's mediocre yields for many, a major shakeup may be welcome. Only be reexamining and reimaging actor-networks are other realities possible. Much needs to change in Lot and the truffle as good of a guiding light as any to take us there. 


\section{Chapter 6: Discussion}

\section{A. Introduction}

In this sixth and final chapter of this dissertation, I will begin by offering an overview of my data driven chapters. Next, I will synthesize these findings to try to imagine different actor-networks beyond that of "modern trufficulture". Taking the detailed historical nature of this dissertation into account, I will propose alternative futures for trufficulture in Lot. These proposed avenues question the very idea of a "modern" trufficulture by drawing on Latour's (1993) discussion of the "modern" and "nonmodern". Instead of hoping to create truffières in increasingly "purified" landscapes, I argue that Lot's trufficulteurs have few options other to embrace landscape "hybridity" and try to make these relations work for alternative forms of trufficulture. Finally, I offer reflections on ANT and the truffle as well as some broader implications of my findings.

\section{B. Lot's Truffle Golden Age}

In Chapter 3, the first data driven chapter of this dissertation, I examine the actornetworks, which would even make the "golden age" of the truffle possible in Lot. After reviewing the creation of the département of Lot and the difficulty of farming there, I turn to the important relationship between viticulture and trufficulture in Lot. Then I describe the "golden age" of trufficulture in Lot.

One of the amazing hybrids in this dissertation is the phylloxera epidemic. I began the data-driven chapters of this dissertation in Chapter 3 not with the truffle, but the phylloxera aphid. Its role is that fundamental. Yet as Busch and Juska (1997) with their transnational study of canola oil and Tsing's (2015) global study of the "multispecies worlds" of matsutake mushroom, one can begin anywhere with an actor-network and 
trace it back to another given point. Also from a methodological standpoint, I followed ANT's ethnomethodological leanings and listened to actants and traced actor-networks accordingly. During countless conversation in Lot, trufficulteurs and others cited the phylloxera epidemic as a foundational moment in the development of trufficulture in Lot.

Additionally, Baux (1982) called the phylloxera epidemic the most dramatic event in Lot during the $19^{\text {th }}$ century. Seen though ANT, it is a fascinating actor-network. Here we have a nonhuman actant, which humans accidently introduced, that killed another nonhuman, grapevines, on a massive scale, caused humans to debate public policy in newly formed committees, altered land values and motivated people to leave Lot.

Lot was revolutionized because a group of amateur gardeners in the UK and France wanted to plant American grapevines, grapevines on which phylloxera tagged along (Planchon 1875). Again, no intentionality either on the part of the gardeners or the aphid would eventually revolutionize French viticulture (Campbell 2004). As the aphid swept across Lot's vineyards with shocking rapidity, many would eventually turn to trufficulture for succor (Meulet 1889). In fact, pre-phylloxera, few documents discuss trufficulture in Lot. Post-phylloxera trufficulture became a frequent solution for the misery facing Lot's famers. It seems to emerge in the wake of phylloxera.

I describe the decades leading up to phylloxera as well. All the planting of grapevines that proceeded it amplified its disastrous effects. By doing so I historicize phylloxera's disastrous outcomes. I temporally extend it actor-networks beyond the descriptions provided by my informants.

At first, Lot seemed fortunate. Its grapevines were spared from the powdery mildew attacks that affected much of the rest of France. As wine production declined 
elsewhere, and price rose, Lot's farmers rapidly planted grapevines on nearly every available surface. Baux (1982) calls this time "wine madness" because of the rapidly rise prices and massive replanting. At the same time, as in other areas of France, deforestation rates were at their highest, which freed up more land (Pradel 1914; Valserres 1874). High rural population densities, low economic diversity and skyrocketing wine prices meant that thousands of hectares of forests were cleared in Lot (Baux 1982). This forest clearing created ideal conditions for reforestation projects through trufficulture (Valserres 1874).

By the 1870s the phylloxera aphid, an accidently introduced American species, would change everything in Lot (Planchon 1875). Lot would lose roughly 55,000 ha of grapevines between the 1870s and 1912. One single species of aphid in effect changed the land cover of nearly $1 / 10$ the département! I detailed in Chapter 3 how forming an actor-network that would promote the use of hybrid plants of composed of phylloxera immune American rootstock with French vines needed to defeat an entrenched group of those in favor of chemical treatments or drowning. Yet, records show that much of the causses lands, the most suitable lands for trufficulture could not support these hybrid plants. Therefore, trufficulture became even more important as these lands could not support any other crops (Rey 1889). Meulet (1889) writes that many faced the grim choice of either emigrating or planting a truffière. Unfortunately for the future of Lot and trufficulture, many farmers chose the former.

Therefore, it was the phylloxera epidemic that radically transformed trufficulture. It is this relation that forever altered the landscapes in which trufficulture was practiced (Castelnau 1978). Had Lot experienced the industrial revolution or had large cities that offered other work, potentially the phylloxera crisis would not have been as dramatic. As 
De Lamberterie (1874) said, agricultural land was the principal workshop of Lot's citizens. It would not provide wealth, but it could provide subsistence. Trufficulture not only kept some farmers from emigrating after phylloxera (Meulet 1889) in other cases it allowed farmers to build new houses (Castelnau 1978).

In the areas around Martel transformed communes from being some of Lot's poorest to some of its richest (Bosredon 1887). Based on my findings it is unlikely that trufficulture could have become such a transformative actant without the phylloxera epidemic or the proceeding powdery mildew scare. Taking ANT's sensibility of relationality serious (Latour 1999), I decided that a thorough description of the phylloxera epidemic in Lot was not only necessary to understand trufficulture in the late 1880s but also the trufficulture of today. ANT acknowledges that spatial and temporal scale shifts with actor-networks. Neither Euclidean distance nor the even march of time predominates in actor-networks. Instead, it is the strength of relations that influences spatial and temporal connectedness in actor-networks (Latour 1996a).

I continued the detailed descriptions of the first half of Chapter 3 on phylloxera to that of the truffle's "golden age" in the second half. I have frequently used Chazoule's (2004) labelling of the period roughly from 1870-1920 as the truffle's "golden age" throughout this dissertation. I repeat this term for four main reasons. The first is to underscore just how high truffle yields were at the time, especially compared to those of today. Secondly, I more cynically employ it to buttress my opinion that recreating the actor-networks that produced these yields at the scale of the département of Lot is all but inconceivable. Realistically, using current practices, one should not even hope to repeat such yields given how much conditions have degraded for trufficulture in Lot. Thirdly, 
by enforcing this period's relationality, I show how the uptick in truffle production came as a response to the misery and chaos inflected by the phylloxera aphid. Many farmers in Lot were just trying to save their land and livelihoods (Meulet 1889) though some individuals and even communes did benefit from these heights of truffle yields (Bosredon 1887; Castelnau 1978). Lastly, I use the term "golden age" as a kind of challenge to describe as closely as possible actual yields for Lot as well as the what happened at the plot level. I sought to discover just how golden it was to provide a high bar for which today's trufficulteurs can strive. If one hopes to restore trufficulture, I knew trufficulteurs needed the most accurate baselines possible during the height of its yields. Whether they can ever be matched is another question entirely.

The precision with which I attempt to describe this "golden age" adheres to ANT's interest in materiality (Latour 2005). Instead of taking a more materialist approach that would argue that massive economic change or other 'structural' forces are behind this truffle "golden" age, I follow the material impact that actants make (Bennett 2009; Latour 1996). Again, the goal of any ANT case study is to craft the richest descriptions of actor-networks and not immediately look for explanations (Latour 2005).

What is frustrating about such strict attention to materiality is that no systematic records for truffle production exist until 1900. Forms did not even include truffles as a category until that date. While Chatin (1892) and Vire (1907) collected independent data about truffle production that shows dramatic increases between the 1860s and the 1880s, no official governmental records exist for truffle harvests from this period. There the "golden age" of the actor-network that I trace begins with archival truffle data. 
Therefore, the "golden age" that that can be demonstrated through archives begins in 1900 and not decades before as other data suggest (Chatin 1892). By 1908, Rey (1908) argues that truffles had earned Lot 500,000 fr in revenue from plant, "artificial" truffières. Prices at the time hovered around 10fr/kilo (Larue 1906), dramatically lower than today's prices. Yet, these yields had a highly geographically uneven distribution. The arrondissement of Martel in the north almost was Lot's powerhouse truffle region. It produced double the number of truffles than the southern arrondissement of Cahors. Larue (1906) wrote that the commune of Martel had one of the most impressive truffle markets in the world. Bosredon (1887) cites communes of the canton of Martel as having seen the most positive gains from trufficulture. Most of the sustained grapevine replanting occurred in the arrondissement of Cahors, while Martel seems to have dedicated itself more to trufficulture in the wake of phylloxera.

Considering that truffle production in Lot now vacillates between one and three tonnes (Sourzat 2009), it is difficult to comprehend that its median production in Lot from 1910-1932 was 170 tonnes. In 1910 trufficulteurs in Lot produced 288 tonnes of truffles. If one assumes that today's totals will stand in the future, trufficulteurs in one year produced what Lot's trufficulteurs now could in the next century.

After reading these figures, I soon began to wonder about how much land was needed to produce these astronomical truffle yields. To more accurately discern the brilliance of this "golden age" I realized I needed to think more spatially about trufficulture. As Law (2004) argues in ANT there is nothing but the local. We must "look down" as much as possible at an individual truffière or as close as the statistics allow. 
Thinking about contemporary trufficulture, one wonders if past yields were the product of more hectares in truffières, higher per hectare productivity or both.

Larue (1906) estimates per hectare yields of 100-150 kg/ha. Therefore, Lot would need roughly 2000 ha in truffières to reach its peak production from that time. The greatest insights into yields came from a document about the damaged inflicted by sheep in truffières (Département du Lot 1908). This document says that the canton of Martel alone had 1491 hectares of truffières, though half that amount had been recently planted. There were 312 trufficulteurs in the canton alone, when there are roughly 500 trufficulteurs today in all of Lot, many of whom practice trufficulture as a passion or hobby. Taking production totals from that time, Martel was averaging $83 \mathrm{~kg} / \mathrm{ha}$. Using the same data for the département, average yields were $78 \mathrm{~kg} / \mathrm{ha}$.

One can glean from the data that on average trufficulteurs only managed 1.60 hectares of truffières, which means for many, trufficulture only provided supplemental income and was not their profession (Rey 1908). With such small truffières and the comparative low prices at the time, the average trufficulteur could expect to earn roughly 5,372 in 2016 Euros per year from trufficulture. With today's astronomically high prices one would only need to sell roughly eight kilos a year to earn as much. With such prices we can see how much truffle as a commodity has changed. Tuber melanosporum truffles are now roughly 20 times more expensive than they were in 1910. Per hectare truffle yields as of late have on average been under five $\mathrm{kg} / \mathrm{ha}$ (Callot 1999) compared to roughly $80 \mathrm{~kg} / \mathrm{ha}$ during the early $20^{\text {th }}$ century. While a few current trufficulteurs match these historic yields (Chevalier and Frochot 1997), they are certainly in the minority. 
Even with prices far below those of today, by 1910 people were still planting truffières throughout Lot. There were over 2000 active trufficulteurs (Département du Lot 1908). Single markets like that of Limogne would alone see trade of 24 tonnes of truffles in a single season. At a single market day in Limogne 3.5 tonnes of truffles were exchanged. Such quantities were traded at single market at a time when Lot had over a dozen truffle markets, with Martel and Cahors having higher quantities of truffles exchanged. This newfound ease of exchange came from a variety of developments beyond increases in production. New associations were needed to extend the truffle's actor-network to the world. Mushrooms never circulate easily. Skilled pickers, buyers, conservers and intermediaries are needed to convert something 'wild' into a tradable commodity (Tsing 2015). Such actor-networks rapidly developed in Lot for the truffle.

Mayssonnier (2010) describes how a variety of actants helped truffles circulate. Truffle houses emerge who would buy and sell truffles. They were staffed by traders who had recently gained the requisite skills from France's newly developed system of public education. Other investments in literal networks such as train tracks and telegraph lines further facilitated truffle commerce. Buyers would leave Lot and buy truffles in other French markets and would even venture to Italy. They could communicate prices with the home offices via telegraphs. They could ship truffles back to truffle houses, firms which all moved their offices to railroad towns. Once back to Lot, these truffles with different provenances would all be packaged and shipped in the truffle house's packaging.

Truffles could truly go global after Appert's methods of food conservation were demonstrated to work with truffles without losing too much of their captivating aroma (Mayssonnier 2010). Rousseau, a trufficulteur and merchant, had demonstrated these 
food conservation techniques at the 1855 World's Fair in Paris and won an award for his efforts (Valserres 1874). Using these same techniques, Lot's truffle houses began to station buyers in New York and Russia selling truffles conserved in Lot. Therefore, all these humans and nonhumans constructed an actor-network linking villages like Souillac, Lot to New York City. Through local sites, Lot's truffles took on a global extension. Increased production brought truffles to the world at affordable prices (Pradel 1914).

\section{The End of the Golden Age}

Yet in the coming years there would be fewer and fewer truffles to circulate. In Chapter 4, I examined the long decline of truffle production in Lot. The first "betrayals" in this seemingly solid actor-network came with the declaration of WWI. Rebière (1974) even dates the end of the "belle époque" of the truffle to 1914. Surprisingly, the price of truffles dropped more dramatically than the yields during WWI. Data for individual truffle markets was not available during WWI. Therefore, one can only speculate whether the markets were not held at all or if statistics were not recorded.

Prices dropped from 11 fr/kilo to only 3.5 fr/kilo. Gay and Gromas (1937) argue that many trufficulteurs were needed at the front. Those who remained behind were much more worried about meeting basic subsistence needs than harvesting truffles. Potentially more damaging, no one maintained these truffières by pruning branches or tilling the soil. Gaignebet (1923) argued that this lack of maintenance negatively altered soil chemistry. He cites informants who said truffières on the causses de Martel had become exhausted post WWI. Others worried that too much truffle knowledge had been lost along with the soldiers who had died at the front (Bye 2000). In fact, average yearly truffle yields before WWI were 227 tonnes, with only 124 tonnes after the WWI. 
While the arrondissement of Martel had long led Lot in truffle production, it was the first place where the gravity of the decline became obvious (Gaignebet 1923). To make matters worse, some officials stopped regularly recording truffle yields. Therefore, actual yields in Martel became harder to track. Perceived declines are in part the result of a lack of data as forms were returned without truffle data. If one depends on these data, then rushed politicians or their staff can drive truffle declines as much as reforestation. I was unable to find any alternative sources of data to fill these gaps. Therefore, these missing helps likely made truffle declines appear that much more brutal.

It was not WWI alone that frayed the trufficulture's actor-networks. Phylloxera had already forced the emigration of many farmers (Meulet 1889). Agricultural modernization elsewhere in France and abroad started an agricultural crisis in Lot, a crisis which some say never really ended, as the department has continued to lose farmers. Imports made agricultural in Lot untenable. Once cheap wheat arrived from elsewhere, this staple of Lot's diet became more expensive to grow there than to buy it (Rey 1899). Throughout the $20^{\text {th }}$ century the surface under wheat and other cereals would diminish.

Wool imports would kill Lot's woolen trade and industry. Sheep would only be raised for meat in Lot. While silvopastoralism on the causses had been many farmers' way of raising sheep, the government soon promoted and incentivized the planting of pastures that ended traditions of silvopastoralism and transhumance. While the number of sheep raised in Lot climbed, the links between truffles and sheep were severed. Today, Lot's farmers compete against cheap lamb imports from New Zealand, lamb which has ironically been raised on natural pastures much as Lot's farmers had once done. 
The economies around wheat, wine, lamb and wool grew ever more precarious by the turn of the $20^{\text {th }}$ century. Lot continued to lose farmers. From a peak number of 100,586 in 1851 , already by 1886 Lot's farming population decreased to 84,176 . Therefore, in only 35 years Lot lost 16,410 farms. By 1929 this number plummeted 34,922 and by 1988 there were less than 10,000 remaining farms. The causses and truffle-producing commune of Limogne would have 439 farms in 1851 they would have only 23 farms by the mid-1900s. Remaining farmers increased their farm size (Chambre de Commerce 1994). Yet, the truffle disappeared from documents. Government officials decreasingly proposed trufficulture as a response to this ongoing agricultural crisis. Massive declines in truffle production almost perfectly mirrors the declines in numbers of farms. While intensive methods could increase herd sizes for sheep and raise per hectare wheat yields, trufficulteurs have not been able to intensify or modernize trufficulture.

Related to its rapid loss of farmers, Lot's overall population plummeted from a high of 295,542 in 1861 to a low of 147,754 in 1954 . Its population declined in every single census during that period. The two biggest periods of losses were during the phylloxera epidemic and during WWI. Villages in Lot sustained such disproportionately heavy losses from war causalities that nearly every village today still has a monument to remember the dead. Additionally, the absence of such a large portion of its male population caused birth rates to plummet. These overall losses in farms and general population also meant that that was a lack of farm laborers. This lack of farmer laborers increased labor costs, which made the reconstitution of Lot's vineyards that much more complicated. It made maintaining a truffière that much more difficult. 
A further result of this simultaneous agricultural and rural abandonment (over 90\% of Lot's communes are classified as rural, having less than 2000 residents) was a largely unplanned forest resurgence. Archival data suggests that forest cover increased from 115,235 hectares in 1931 to 208,00 hectares by 1975 . In the early stages of this forest resurgence wild boar populations exploded. They damaged harvests to the extent that some farmers said that farming was no longer tenable. To control their populations, the state needed to offer hunting subsidies so that they would be eliminated.

One of the most disturbing ironies was that the "golden age" of truffle production arrived in the wake of a perceived countrywide deforestation epidemic and with land clearings by the phylloxera aphid. Trufficulteurs planted oaks on these newly cleared lands hoping to earn income (Pradel 1914; Valserres 1874). In some cantons, farmers reforested thousands of hectares through trufficulture (Valserres 1874).

While trufficulture and reforestation can be mutually beneficial (Pradel 1914), truffle scholars have long acknowledged that its host trees need to be regularly pruned and the ground needs to be tilled. Tuber melanosporum thrives in only certain kinds of forests. If these conditions change, other mushrooms take over (Bosredon 1887; Chatin 1892). Lot's ever-expanding forests, some of which were former truffières were no longer suitable for truffle production (Castelnau 1978; Champagnac 2000). In fact, these expanding forests may have unfavorably modified local climates and introduced deleterious fungal competition (Castelnau 1978; Champagnac 2000; Gaignebet 1923). Even though truffles thrive in forests, reforestation in the wake of agricultural abandonment seems to have been incredibly damaging for truffle yields. 
In the second half of Chapter 4, I continue with my dogged pursuit of materiality, since archival documents did not produce the kind of detail I felt was sufficient. I realized that the classification of remotely sensed aerial historic photographs could provide the necessary detail on land cover change in Lot. Data sources ranged temporally from the mid- $19^{\text {th }}$ century to 2000 . Unfortunately, my two earliest data sources from the $19^{\text {th }}$ century, the Cartes de Cassini and the L'Etat Major did not have the necessary detail to include truffières or smaller patches of forests. Only by 1948 did images have the necessary spatial resolution (pixel size) to provide the kind of needed data to track changings in truffières and small forest patches.

Only Lalbenque saw increases in its area planted in truffières from 1948-2000. In every other commune, including in Lot's former truffle capital of Martel, truffières decreased. Such declines came as truffières transitioned to mature forest. Forest expanded into agricultural land. Even in Lalbenque, Forest cover increased by $8 \%$ at the commune level from 1948-2000. Not only did forests increase overall, large forest masses expanded, the kinds of forests which are suitable habitat for deer and wild boars. Such forests are not suitable to T. melanosporum (Castelnau 1978). Even if truffières increased, the milieu in which they were situated was less supportive of trufficulture.

The data I presented have not been favorable for Lot, much less for trufficulture. For well over a century Lot has lost farms. Using the word 'crisis' seems like an understatement for something that has gone on for over 140 years. A crisis is at some point normalized. The urgency with which Meulet (1889) wrote about phylloxera showed that many farmers did not want to leave, but they had few alternatives. The destructive path of an aphid led them to do so. Yet, phylloxera was only the opening salvo. Outside 
competition would further rock Lot's farmers. Seemingly overnight their ways of farming become unfavorable. As it was such a rural and agrarian département, once agricultural actor-network was torn asunder, Lot's overall population plummeted until the 1950s. Many of these who have returned are retirees taking advantage of the high quality of life. While some have taken up trufficulture, few have returned to run an actual farm.

The Lot of even 1850 would economically and demographically bear little resemblance the Lot of 1950. Yet in "generalized symmetry" (Callon 1984) each version of Lot was the product of actor-networks. Nearly every association was transformed. In hindsight, Tuber melanosporum acts as an indicator species for these changes. Tuber melanosporum needs oak forests that are not valuable for their timber, but because of the truffle as a non-timber forest product. Yet these forests need to consistently and skillfully be maintained by the trufficulteurs (Pradel 1914). Trufficulteur should be set within landscapes dominated by polycultural farming (Le Tacon et al. 2014).

Bosredon (1887) describes how trufficulture associates with other agricultural systems and so describes how trufficulture can support viticultural, cereal cultivation and hazelnut production. Growing them in conjunction can help make the others more economically viable. For others silvopastoralism could play a positive role in trufficulture (Rey 1908). Therefore, you need working, polycultural farmers who can earn supplementary income from trufficulture (Champagnac 2000). Yet, as shown during WWI, you need farmers who not only understand trufficulture, but also who have the time to maintain truffières and harvest truffles. Farmers became both rarer and more intensively specialized. The kind of patch-matrix landscapes produced through polyculture became ever rarer in Lot. I witnessed through historical aerial images how 
closed canopy forests, larger agricultural fields and new human settlements began to dominate Lot's landscape Truffières slowly disappeared in these landscapes.

\section{The Development of Modern Trufficulture}

In Chapter 5, I examined the resurgence of interest in trufficulture by both trufficulteurs in Lot and by a global group of scientists. Over decades of decline thousands of people regained their passion for the truffle and trufficulture. Champagnac (2000) chronicles how he and a group of farmers and scientists helped "relaunch" trufficulture in Lot in the 1960s. Instead of completely returning to past methods, many argued that trufficulture needed to become modernized just as agriculture had.

In the first half of Chapter 5, I examined the science and practices behind this modernization campaign. The most striking new actant to arrive by the 1970s was the inoculated plants (saplings), which tried to ensure host tree/truffle symbiosis. These plants were themselves the product of an actor-network between French and Italian scientists. (Callot 1999; Rebière 1974). They interested government officials, who offered subsidies to offset their additional costs (Champagnac 2000). It seemed that scientists were tackling the most fundamental unanswered questions in the history of trufficulture: why do some trees produce and others do not? (Pradel 1914).

By inoculating the roots of the host tree saplings with the spores of the desired truffle species, it seemed reasonable that this association would continue as the tree grew. After as few as four years production could begin. As major of advancement as these plants seemed to be (Champagnac 2000), it did not take long until problems of contamination appeared. Whether in the laboratory by selecting spores from the wrong truffle in the lab or after saplings were planted, contamination meant that host trees 
would produce other truffle species or nothing at all. Inoculation may have increased the odds that the desired truffle spores would colonize their host, but it did not ensure it.

In the worst-case scenario, spores of Tuber indicum, the Chinese truffle, were introduced accidently in Italy through laboratory plant mycorrhization. Being morphologically similar truffles, $T$. indicum was mistaken for $T$. melanosporum. These truffles could become invasive (Murat 2008, 2015). Therefore, both inattentive lab technicians helped introduced other truffle spores at a truffière. These other truffle spores could "betray" (Callon 1984) T. melanosporum inoculation.

Scholars trying to understand these high levels of contamination and low level of Tuber melanosporum colonization have looked to ways in which governments "certify" that plants have undergone mycorrhization. Andrés-Alpuente et al. (2014) found that methods of certification varied considerably. Therefore, while certain plants would have failed certain inspections, they passed others. The first criteria for plant certification developed in France were far less restrictive than subsequent methods. Others found that different host tree species are more susceptible to contamination than others. (Sourzat 1994). Individual practices in a truffière may lead to contamination or low levels of colonization (Olivier et al. 2012). The difficult work of actor-networks of extending the conditions of the laboratory into a local site must work with many human and nonhuman actants (Latour 1983). Such extensions with mycorrhized plants have proved unpredictable (Callot 1999). Many trufficulteurs have been disappointed with the results of inoculated plants, especially as their cost is far higher (Mayssonnier 2010).

Whether the fault of plant inoculation methods, host species choice or technical deficiencies at the truffière, Sourzat (2009) has claimed that Tuber melanosporum as a 
species has lost its "virulence" against other truffle species. Therefore, when other truffle spores are present in the soil, it is less likely that Tuber melanosporum can successfully colonize the host tree's roots. In early truffle manuals, Tuber melanosporum is an actant virulent enough to kill nearby grapevines (Bosredon 1887; Rebière 1974).

It is fascinating to contemplate the idea of virulence through ANT's ideas of relationality (Law 2009). As a truffles virulence could only be a product of its associations, these associations are different enough from that of 100 years ago that they not only altered certain truffières but potentially the entire species Tuber melanosporum. If this is true, then it is not only that contemporary trufficulteurs need to modify their techniques, but that they are working with an entirely different truffle. Mol's (1999) concept of "multiplicity" explores such phenomenon. I have gone to great lengths to describe how the truffle's actor-networks have changed over the $20^{\text {th }}$ century. For Mol (1999) different actor-networks of diagnosis do not produce different versions of a singular anemia. Instead, they produce entirely different diseases. Different associations produce different actants. It is now possible to recognize that past actor-networks produced a "virulent" truffle while today's actor-networks may produce a less virulent truffle, even if both truffles are classified scientifically as Tuber melanosporum.

Considering a potential loss of virulence and other concerns, scientists have tried to understand why "modern" truffle yields have not even met their most modest expectations (Callot 1999). One important finding from DNA analysis of the truffle is that Tuber melanosporum produced sexually. Therefore, its two mating types must be nearby for truffle reproduction to occur (Martin et al. 2010). For 40 years people have produced inoculated plants under the idea that truffles produced asexually. In such actor- 
networks, sexual reproduction was not a capacity of actants. Therefore, a truffière could became sterile if these mating types are not present (Rubini et al. 2011). Such findings further complicate plant inoculation as well as the planting and management of truffières.

The truffle is not only a sexual being. New findings demonstrate how it acts by markedly influencing local biodiversity. In the creation of brûlés, or denuded areas, the truffle produces chemicals which reduce nearby fungal diversity. Its volatile organic compounds can function as a fertilizer. This alteration of competition seems to allow the truffle to spread its mycelial network outward in the "conquest of space" (Olivier et al. 2012). Therefore, the truffle is not a passive recipient waiting for the tree to extend its roots, but instead it competes against other fungi and plants to form associations with its host tree and then to spatially control the truffière. The truffle also sends out the volatile organic compounds which allow animals like pigs, dogs, slugs and wild boar to find it and spread its spores. The truffle communicates with other actants in these ways. It needs to remake its milieu to thrive (Olivier et al. 2012).

While these findings transform the truffle as an actant in a truffière, other research indicates that the truffle itself is a complex actor-network. Antony-Babu et al. (2013) argue that the truffle is a host to many species of bacteria. It is possible that the truffle searches out these bacteria, which form a "ectomycorrhizosphere" of bacteria and truffles that perform vital functions for one another.

These recent findings of the power of the truffle's volatile organic compounds, its sexual nature and the "ectomycorrhizosphere" are fascinating from an ANT perspective since they drastically modify the truffle's capacities as an actant. Their implications for trufficulture are less clear. This research for now has uncovered an almost unimagined 
complexity regarding the truffle. For example: How does one cultivate a sexual truffle versus an asexual one? Is it possible to promote the production of brûlés and the truffles conquest of space? Can one foster the ectomycorrhizosphere? My review of the literatures suggests that scientists have only begun to consider these questions. Scientists continue to alter the truffle's ontology, though for now the political implications of these interventions is unclear.

In the second half of Chapter 5, I wanted to understand what trufficulteurs found to be the greatest challenges of practicing trufficulture today, after it had supposedly been 'modernized'. In analyzing the results of my semi-structured interviews, which I conducted with 42 trufficulteurs in Lot, I found persistent difficulties with contamination and low inoculation as described above. Inoculated plants have proven unreliable in Lot. The median number of productive trees was only $15 \%$. At roughly 15 Euros a plant, such low percentages are serious for the economic viability of trufficulture (Mayssonnier 2010). Trufficulteurs as well reported moderate fungal contamination mainly from Tuber brumale. Only $10 \%$ of trufficulteurs had not planted inoculated plants. Despite their widespread adoption, half of trufficulteurs were certain that certified plants were better than those produced by trufficulteurs. Contamination was particularly prevalent with hazel trees, which many had recommended plant as it was believed that they would produce more precociously than oaks.

Another major difficulty came from the impacts of anthropogenic climate change. Only 14\% of trufficulteurs said that anthropogenic climate change was not occurring. Most said that the seasons had become less marked and that summer droughts and heat 
waves had become more intense because of climate change. Of those who recognized anthropogenic climate change, $89 \%$ said that it was affecting trufficulture.

The most common adaptation to anthropogenic climate change was the installation of irrigation systems. Despite the recognition that irrigation systems were becoming obligatory because of climate change, many had not installed them because the high costs. Some worried that excessive irrigation would mute the truffle's perfumes. Instead of irrigating, other would trim branches to help retain the soil humidity.

In addition to installing irrigation systems to mitigate climate change, many trufficulteurs felt it necessary to install tall wire fences or electric fences to protect their truffières from deer and wild boar. Most installed simple electric fences because they found the wire fences to be too costly. They said that deer would rub against young trees, killing them. Wild boars would violently upturn the soil and hurt a truffière's productivity. These tall fences could also protect their truffières from human truffle thieves. While few said human truffle thieves were a major problem, they were a concern. While thieves were a more prevalent concern in historic truffle manuals, large mammals like deer and wild boars were scarcely mentioned. Previously, truffle had been so abundant that thieves would even rake the ground in search of truffles (Chatin 1892). Surveyed trufficulteurs concur with many of the reasons for the $20^{\text {th }}$ century declines in truffle harvests in Lot. They emphasized how much forests had replaced agricultural fields. As the average age of trufficulteurs was 63 -years-old, many had themselves witnessed reforestation in Lot. Reforestation altered actor-networks to the extent that these unmanaged forests became more susceptible to caterpillar attacks, which 
Given their deep understanding of truffle declines, few were unreservedly hopeful about the future of trufficulture in Lot. The more optimistic trufficulteurs emphasized how much work people had put in to replanting and forming syndicates and associations. They felt that interest in the truffle was returning and that more people were replanting. They hoped that younger farmers would be interested in the truffle. Others were much less hopeful. They felt that the climate had turned against the truffle. Others felt that reforestation had made trufficulture much more difficult. Others said that if there were not fewer farmers in Lot, then the land would grow inhospitable for the truffle.

Yet, these surveys made it clear that many of the trufficulteurs worked their truffières far more out of passion than economic motives. Only one trufficulteur interview could earn most of income from trufficulture. As most were sixty years or older, they were retired. Many had pensions. Therefore, trufficulture did not need to provide them income. Others mentioned that they were too old to make major investments in their truffière like irrigation systems or fencing. Those without a successor often stated that they were disinterested in expanding their truffières, because no one would be there to take care of them in the future. They could practice trufficulture in the way that fit with their goals.

As de Laet and Mol (2000) found in studying how different villages had taken the same hydrological system, the "bush pump" and made it work with different repairs or with missing parts altogether. Instead of upholding technological determinism, the bush pump showed remarkable "fluidity". I argue that trufficulture in Lot demonstrates a similar kind of "fluidity". Contemporary truffle manuals suggest that inoculated plants, irrigation systems, tractors and high wire fencing all are necessary (Hall et al. 2007). 
Yet trufficulture works for many trufficulteurs without these actants. While their yields may vary, they have crafted a kind of trufficulteur which fits within their constraints of not financially depending on production, being older and potentially not having a successor. Yet, they planted a truffière when so many farmers and non-farmers had not. In one case, one trufficulture had felled roughly three hectares of forest, let it lay fallow and then planted a truffière. Such work clearly reverses the deleterious trends of reforestation. Yet so few trufficulteurs seem interested in such work.

As Latour (1987) argues, one cannot wait for a technological project to work and its actor-network to have stabilized before trying to join this actor-network. It is only through the assembling of more humans and nonhumans that a project can succeed. These trufficulteurs are doing the important work of continuing trufficulture and trying to make it work in many "fluid" forms. Without their continued efforts, trufficulture would be in danger of disappearing from Lot (Champagnac 2000).

Here, I have purposefully juxtaposed in this chapter the ambitious aims of truffle science and the trufficulteurs of Lot who often engage in trufficulture because of their passion for the truffle. I do not intend to denigrate either group, but the ambitions of scientists and trufficulteurs seem so unbalanced. Truffle science is rapidly advancing, seemingly only to find more mysteries, while nonprofessional growers are not likely to be able to synthesize such complex findings in practice. The fact a truffière takes 10 to 15 years to reach its productive potential only further complicates matters as the last ten years has seen considerable change in the truffle's ontology (Murat 2015).

Truffle science in the last 15 years has at least in theory transformed the truffle's actor-network. It is now a sexual being, whose volatile organic compounds and virulence 
engages in the conquest of space, while bacteria and yeasts interact with it in the ectomycorrhizosphere. These discoveries may or may not inform on the ground problems that Lot's trufficulteurs face from low rates of colonization, persistent fungal contamination and uncertainty regarding climate change's effects on truffles. While scientists may have "composed a common world" (Latour 2004:18) that is novel, the far greater challenge is how can trufficulteurs translate these findings into actual practices. Thus far yields from inoculated plants have not met their most modest expectations (Callot 1999). Certain relations are subject to constant betrayal (Callon 1984). The truffle remains far from “tamed” (Hall et al. 2007) by 'modern' methods.

\section{E. Recommendations for a Nonmodern Trufficulture}

The actor-networks I have assembled lead to clear, though likely difficult to implement recommendations: 1) Lot needs to only retain the farms it currently has but encourage many more people to work its lands; 2) These farmers if possible need to look to past polycultural systems that diversify instead of specializing on one crop; 3 ) Trufficulteurs need to imagine ways to re-embed their practices within polycultural farming systems that place forests within these productive systems; 4) Therefore, while highly capitalized "modern" truffières are suitable for some farmers, trufficulteurs need to be still more creative and diverse in their practices that not only mix current with past techniques, but develop a trufficulture that can face anthropogenic climate change.

While these recommendations are ambitious and would require the marshalling of vast hybrid actor-networks to achieve them, doing nothing is no longer an option. During my research in Lot, I encountered a profound crisis of wasted talent and knowledge as farms were in danger of being shuttered. Increasingly, one cannot practice the craft for 
which they train and in which they excel. Sadly, the techno-centric mode of agricultural modernization that cheered on the end of peasant farming systems (Mendras 1970) went global. All those who keep up were deemed as necessary causalities. Farmers had to take on debt, try to keep on modernizing or quit farming (Berry 1978; Cullather 2010).

All throughout agricultural modernization, the hope was that a declining number of farmers would continue to produce more commodity crops. 'Backwards' peasants/farmers ostensibly could then migrate to cities where industrial jobs awaited them. No one worried how exactly fewer farmers would produce more food, or if the result would be ecologically damaging or if this produce would have any taste.

Most in rich nations imagined an economy that would grow predictably and exponentially for all times. If farmers produced additional calories to feed their populations that was all that mattered for many states (Cullather 2011). "Modern" agriculture and forestry, and their claims of progress (Tsing 2015) become all that much more farcical when it comes to trufficulture. Trufficulture highlights its drawbacks of an ever-dwindling number of farmers producing tasteless food under 'modern' or 'industrial' methods. Crisis of overproduction and price shocks rock many agricultural commodities. Truffle yields have instead plummeted over the last century, while real prices have continued to multiply. Fewer farmers have produced fewer truffles.

Lot is blessed with beautiful landscapes, picturesque markets and skilled farmers. There is no question of food quality. Lot produces delectable truffles as well. Yet only a handful of people can be professional trufficulteurs. Likely in the past there were few professional trufficulteurs as well (Bosredon 1887; Chatin 1892; De le Bellone 1888). 
Yet, in the past there were far more farmers would have also been trufficulteurs (Castelnau 1978; Champagnac 2000). With much larger farming populations, many would have maintained at least a small truffière or harvested truffles from "natural" truffières as a pasture's edge (Delpon 1831). Risks were spread out. The truffle even at its height, remained mysterious (Pradel 1914). Yet with so many farmers, even if only some unlocked some of its mysteries, Lot's production could remain high. These markets attracted tourists from around the world (Larue 1906). Trufficulture transformed some communes in Lot from being amongst the poorest to some of its richest (Bosredon 1887).

This large agricultural population cleared land and put an unprecedented number of hectares under cultivation in Lot (Baux 1982). Silvopastoralism was widespread on the causses (Rey 1908). While some worried about such levels of deforestation and its impacts on erosion and local climates (Pradel 1914; Valserres 1874), these cleared landscapes were incredibly suitable to truffle cultivation (Castelnau 1978). The number of farmers and number of hectares farmed closely correlates with truffle production (Chambre de Commerce 1994). Champagnac (2000) argues that "peasants" are "landscape architects". Peasants in the late $19^{\text {th }}$ century produced landscapes perfect for the trufficulture (Castelnau 1978).

My survey interviews showed how trufficulteurs agree that there are fewer and fewer farmers in their vicinity. The number of peasants as "landscapes architects" have declined, much to the detriment of trufficulture (Champagnac 2000). My remote sensing work quantifies how Lot's landscapes today are remarkably less suitable to trufficulture than they were 100 years ago. Restoring production seems to grow more difficult with other farmer that leaves the land. One cannot deny the need for working with these 
forests if trufficulture is going to improve in Lot. Lot's expanding forests could become truffières if they were worked. Unworked they provide habitat for competitive fungi, deer and wild boar, all which can damage a truffière.

While today there are many hobbyist trufficulteurs in Lot and elsewhere (Therville et al. 2013) many in Lot call for remaining trufficulteurs to become "serious", concentrate on increasing production and not folklore. I find this argument to be highly debatable. It rehashes previous modernization claims/In France, all the time, money, subsidies and work have not even met the most modest expectations for yields (Callot 1999; Mayssonnier 2010).

On average each French trufficulteur produces only a single kilo of truffles a year (Savignac 2008). Contrarily to all results over 40 years, people keep imagining that a single "scalable" solution (Tsing 2015) awaits from a newer "model" of trufficulture (Chevalier and Pargney 2014). It is this idea of "modernization" of an ever-brighter future of progress (Tsing 2015) and a horrified escape from the past (Latour 2014). This future "golden age", which always seems to be right around the corner, never comes. It has past trufficulteurs by. It is the past I have reanimated.

In the case of trufficulture, yields were dramatically higher 100 years ago then they are today (Callot 1999). If we are naïve enough to believe that modernization is the story of progress (Latour 1993; Tsing 2015), then the story of truffle is the story of regress. It howls out against the hopes that we could tell millions if not billions of farmers that we no longer need their labor and that they should just do something else, whatever they could come up without much if any assistance. We eviscerated untold knowledge without any disregard. Now we pay the price of fewer truffles. 
"Modern" trufficulture is another kind of radical modernist "simplification" (Scott 1998) that extracts the truffle from its complex "hybrid" actor-networks to assume that a single "door-closer" (Johnson 1988; Latour 1993), the "inoculation" of host trees could fix trufficulture. It assumes that no socio-technical "fluidity" is needed (de Laet and Mol 2000). Its models of simple unidirectional technological transfer to willing and entirely flexible farmers (Chambers 1994) is shockingly simplistic. Seen through actornetworks innovation will never be so simple (Akrich et al. 2002).

These "modern" truffle scholars have made the classic mistake of confusing the actual work of constructing actor-networks made of a shifting "heterogenous" assemblage of humans and nonhumans with merely claiming to have achieved a stabilized actor-network (Latour 1996a, 1999; Law 1992). They assumed that in calling something "modern" and creating simplified models for its functioning that they had changed the actual materiality of actants (Scott 1998; Tsing 2015). Yet the truffle as a "spokesperson" has "betrayed" such claims all too frequently (Callon 1984). Such a narrow kind of modernization hopes to fix one broken "door-closer" (Johnson 1988) with plant inoculation and then hopes that all other actants somehow reform around it. Yet a single broken "door-closers" changes the associations of many actants (Johnson 1988).

I have gone to great lengths to show that truffles were "never modern" (Latour 1993). The necessary "work" by humans and nonhumans to modernize them, if even possible (Bye 2000), has not occurred (Callot 1999). Following "modern" agriculture one could blindly and disastrously hope that actual modernization awaits around the corner, while failing to see that such teleological claims all too often have had perverse outcomes (Scott 1998). Science rarely if ever moves simply and uni-directionally towards progress 
(Kuhn 2012). To again quote Latour (2007), the most important human actant in this dissertation, the urgent choice we have is to "modernize or ecologize".

I have argued that by "ecologizing" trufficulture is not only be creating new truffières broadly under the ideas of "modern" trufficulture that include "inoculated" plants, irrigation systems, tractors and fences (Hall et al.2007; Olivier et al. 2012). Instead more farmers and landowners also should practice "truffle silviculture" (Diette and Lauriac 2005) to try to reopen closed canopy forests that may make them more suitable for truffle production. Mature forests, whether they produced truffles in the past, are managed to produce them through judicious pruning and continued maintenance.

I am fully convinced that the restoration of landscapes is the key to trufficulture in Lot. Its worked forests once produced truffles (Delpon 1831; Rey 1908). There is no reason to believe they cannot again (Champagnac 2000). Having lived and volunteered on a farm in Lot which practiced a particularly skilled form of silvopastoralism, I saw that it is possible, but labor-intensive. On this farm, the forests looked like a sparse truffière as grazing and thinning for fuelwood had keep it open. It seemed like a model farm for truffle silviculture, though the farmer had no interest whatsoever in truffles.

Roughly 100,000 hectares of Lot became forested over the $20^{\text {th }}$ century (Chambre de Commerce 1994). These could be managed for fuelwood production, silvopastoralism, trufficulture or a combination of the two. Lot's oak forests were never valuable for timber. Yet, it was the sheer number of farmers and the extensiveness of their polyculture farming systems that made landscapes so favorable for the truffle (Baux 1982; Rey 1908). The same landscapes were less favorable for deer and wild boars as well. Trying to create conditions suitable to the truffle would in many ways aid other farmers as well. 
Yet such changes need to undo how Lot's farmers for decades have focused on the flattest and most fertile land which, was suited for agricultural machinery that helped them grow commodity crops. Elsewhere French farmers have not resoundingly embraced calls for multifunctionality (Kohler et al. 2014). France successfully made its "peasants" "vanish" and become professional farmers or exploitants (Mendras 1970). Many trufficulteurs in Lot described how much the "mentalities" of famers had changed over the last few generations in favor of monocultures that produced reliable and subsidized crops. The long production times, considerable investments and uncertainty of truffle production failed to attract many farmers.

Different forms of trufficulture, either "modern" or "silvicultural" practiced in locally adapted ways based on innovation and empirical observation (Gregori 2008) can help struggling farmers financially (Castelnau 1978). Champagnac (2000) argues that the truffle created so much wealth for Lot in the past and that it can do it again. Yet there will need to be farmers, and not only those enthralled by modernization who remain in Lot to make that a reality. The truffle demands open canopy forests with consistent and knowledgeable human intervention (De le Bellone 1888). Having both throughout Lot will be a major challenge if the gospel of modernization still attracts adherents.

I would like to rethink that improved truffle production would be a clear sign of further revitalization in Lot. Famers and truffle markets already bring in many tourists, even if these tourists do not regularly buy truffles. Lot once had at least ten regular truffle markets and now has only two. Promoting the truffle at touristic markets has been important in sustaining interest in the truffle. Some trufficulteurs call such promotion mere folklore. Yet, this folklore is not wholly divisible from production. Even if few 
tourists buy truffles at markets, Lot's few remaining markets seem to exist as much for folklore as they do for selling highly varying quantities of truffles. These markets put Lot on the figurative truffle map as many national film crews often highlight it.

Beyond the skilled promotion of their markets, the current approach for trufficulture in Lot is piecemeal and relies far too much on a few "serious" highlycapitalized trufficulteurs to produce most of the départements truffles. Hoping to attract many more people who have hundreds of thousands of dollars to invest in trufficulture will not be easy. Production as before should be more collective. Instead Lot will have to begin again in heavily forested landscapes, more unpredictable climates and with a truffle that may have lost much of its "virulence" (Sourzat 2009). They must work with these changes, while also attracting hundreds if not thousands of new farmers who will include trufficulture within their farming practices.

Having supposedly “vanished” 'peasants' (Mendras 1970), Lot needs to attract a new group of peasants. The Lotois need to engage in tourism, forestry, silvopastoralism, hunting, trufficulture, and many other kinds of farming to restore open canopy forests and landscape heterogeneity. This will be much more of a collective effort, by humans and nonhumans. One cannot hope for only a few "serious" trufficulture to do it all.

In Lot and elsewhere, we need to truly understand the benefits of "multifunctionality" (McCarthy 2005) and that we likely will need far more farmers than we have now to create such complex landscapes. Attracting them will not be easily, but multifunctionality in Lot likely depends on it. Such professions cannot be sacrificed on the altar of "modernization" and the hopes that its fruition is finally, at last, right around the corner. The "modern parenthesis" has closed (Latour 2015). 
Maddeningly, agricultural areas around the world like Lot are facing such long uphill climbs. With insistent calls for austerity and most feeling squeezed there is little push to reinvest in areas like Lot that produce small fractions of national GDPs. Farming has been made into a profession that produced more debt for the farmer than quality food for the populous. Surely, there is no easy way out, no quick fixes or panaceas. Still we must reimagine the varied kind of renovations possible in the "ruins" of modernization (Tsing 2015). The truffle shines a harsh light on the failures of modernization. It puts into stark relief the limits of our apathy to declining agricultural areas. It demands a cleared, maintained and vibrant countryside to sustain it.

The truffle today in Lot produces passionate people willing to spend considerable money and time trying to 'cultivate' this capricious and mysterious fungus. The truffle appeared on the verge of disappearance as declining farming populations and resurging forests seemed in confederacy against it (Castelnau 1978; Champagnac 2000). The work in Lot has begun. So much more work is needed to refashion a viable truffle actornetwork out of the ruins of the last 100 years.

Now is the time to diverge from the "modern constitution", to embrace the increasingly "hybridity" of the truffle's actor-networks (Latour 1993) and to modify and adapt to these new assemblages in a way that will strengthen one of the most wonderful places of all, Lot France. Trufficulture has already helped 'save' Lot after the phylloxera epidemic (Meulet 1889), it can no doubt help strengthen Lot again.

We need to follow Latour (1993) and admit that "modernity" never produced the elegant "purification" of "nature" and "society" as it claimed. While we should not bath in the hopeless misery of postmodernism or yearn for an idyllic "premodern" past that 
never was, we must be "nonmodern". I have used the truffle as my guiding light through the darkness of modernity in Lot. Now and in the future, we must embrace trufficulture as an alternative and to manage "hybrid" actor-networks (Latour 1993) in its favor. We must end all conceits of "taming the truffle" (Hall et al. 2007), but instead carefully “extend" its actor-network (Latour 2010) across Lot with trufficulture's rich history as a guide. A whole army of new actants must be mobilized. That is the vital work in store for all those passionate about the truffle.

\section{F. Broader Implications of ANT as Seen Through Trufficulture}

In tracing the truffle's decline, I have chronicled a series of damaging actants who have transformed Lot. Yet, I again do not claim there is a "system-builder" at work (Law 2009). I do not imagine there was ever an orchestrated plot against Lot's trufficulteurs.

Yet declines undoubtedly happened. The situation was dire enough that people were worried truffles might eventually disappear from Lot (Champagnac 2000). One's instinct is to find the responsible party. Yet in my account there are many responsible parties, many of whose agency became intertwined in hybrid actor-networks. Searching for many responsible parties who are human and nonhuman is a novel detective story.

Bennett (2009) makes the trenchant argument that if one is going to attribute a kind of collective agency to hybrid actor-networks for its maintenance, then one cannot choose a single actant to "blame" if the actor-network unravels. One cannot then attribute all agency to humans. I claim that differing hybrid actor-networks drove truffle production increases and declines. All yields were the product of hybrid actor-networks, while relations changed. No one actant, human or nonhuman was responsible for rising or 
falling production. It would be hypocritical then to only look for humans to "blame" when discussing truffle declines.

Still, "blame" is a tried and true humanistic political device. As Bennett (2009) describes, it was true that speculative energy trading encouraged relations that led to electric blackout, but many other humans and nonhumans made it possible. Speculative energy traders drove blackouts as did fires and the limited distances over rich reactive power can travel. Humans and nonhumans without intending to do so, created an electrical blackout. For Bennett (2009) politics must include all these entities. For Latour (2004) politics begins with the description of what actants create effects.

Returning to phylloxera, what precedents in Western jurisprudence would allow one to legally "blame" aphids for the destruction of grapevines? One could try to blame the amateur gardeners who imported the plants, but it unrealistic to assume that they could have envisioned the scale of the disastrous outcomes of planting a few American grapevines in Europe. As it turned out more American plants needed to be imported to produce hybrid, immune rootstock. Even though the aphid made the transatlantic journey on these plants, actor-networks needed to stretch more intimately from France to America to find a cure by important even more American grapevines (Planchon 1875). Humans and nonhumans needed to enter new hybrid relations to save viticulture.

The politics of "modernity" and the "Great Divide" seeks to "purify" an event into that of nature or culture, in part to assign blame. Such divisions in effect retain humans as the ultimate agents (Goldman et al. 2011), even if they are not alone responsible for outcomes (Bennett 2009). What might be the point of a descriptive ANT account if one will not limit agency or culpability to humans? Yet, if all actants like 
truffles or even humans as hosts for the ecosystem of bacteria, fungi and viruses, and are in themselves actor-networks, what can be done? Is one rendered helpless by the complex hybridity of actor-networks without human agents to blame?

A related matter to the question of blame is that of the intentionality of actants. ANT does not make demands that actants demonstrate any "intentionality" (Callon 1984). Latour (1996) does claim that train cars 'decided' not couple together during a test run. Callon (1984) assumes no intentionality on the part of scallops who did not anchor to the structures put in place for them. Yet, if one does not demand demonstrable intentionality from individual actants, then it is not necessary that actor-networks share a single clear intentionality. One would then have to attribute characteristics to the whole which do not belong the part, an idea ANT is steadfastly against.

One then should not imagine some automatic collective agency in actor-network. It may be present or absent. I argue that the decline of truffles occurred without intentionality. Data suggests that other related actor-networks such as agricultural abandonment and their resulting forest resurgences or anthropogenic climate change have little if any clear intentionality. Major changes, salvation and tragedies occur without clear intentionality. Without some presumed collective intentionality, Lot was revolutionized by hybrid revolutionaries who expressed no revolutionary ethos nor were aware of their part in a revolution. No one actant was clearly to blame.

Some perceive the deemphasizing of intentionality and the focusing on hybrids or nonhuman agents as an affront to social scientists' "radical" political project (Spicer and Whittle 2009). I vehemently disagree with such a notion. Instead, I agree with Latour (2004), who responds to such critiques that politics relies in the "progressive composition 
of a common world". Others argue that one cannot accept that there is an intrinsic divide in the "production, application and circulation of scientific knowledge" (Goldman et al. 2011). Choosing what entities can and cannot act as well as whether they are included as actants that are co-constituted in actor-networks and affect other actants is profoundly political (Latour 2004). The potential inclusion of the "missing masses", the actants which others neglect, becomes political (Latour 1992). Without intervening on this fundamental level, one often limits their political struggles to the ways in which knowledge is applied (Goldman et al. 2011). ANT makes interventions at the ontological level to challenge power dynamics and imagine things differently (Law and Singleton 2013). I have used this power of intervention liberally in how I envision the future of trufficulture in Lot. ANT helped me look far more expansive in time, space and in my choice of the actants than I believe are necessary for trufficulture.

Throughout this dissertation, I tried to be clear that I did not blame truffle scientists, trufficulteurs, producers of inoculated plants for low yields. Instead, I engaged in the "progressive composition of a common world" (Latour 2004:18) that included phylloxera, reforest resurgences, imported wheat, deer, climate change, agricultural modernization and wild boars.

The entire political terrain for me shifted from limited interventions of improving inoculated plants or better understanding irrigation dosages and timing to trying to attract new farmers to Lot and to promote polyculture farming practices. The actor-networks I envision then would not just transform trufficulture, but would transform Lot. Hybrid agency advises such transformations. 
Again, I am not saying such changes are easy nor are they supported by recent political or economic trends. Only complicated processes of assembling such actornetworks is possible. No one can control it. Yet, if I am right that such actor-networks would benefit farmers, trufficulteurs and gourmets, then I am convinced that they are worth achieving. With such recommendations, truffle science does not stay in laboratories, but like Pasteur's work with anthrax, it will need to work on widespread farms, even if conditions are made like the lab (Latour 1983).

This farmer and landscape focused actor-network clashes with modernist aims. It leads me to demand that the modernist idea of "taming the truffle" (Hall et al. 2007) must be abandoned. The dream of "scalability" that techniques could be ripped from their circumstances and implemented elsewhere has been a major weakness of modernity. Instead, such projects have only be "seemingly scalable" as they transformed actornetworks in each place where they put in place (Tsing 2015). In other words, hybrids "proliferated" when ostensibly nature was supposedly being severed from culture (Latour 1993). Yet as Latour (1993) reminds us, such purification never happened and at least the West has never been modern. Trufficulture, always connected intimately to surrounding landscapes and the climate itself, has never been modern either.

More profoundly, the persistent seemingly irreversible low levels of truffle production shake one's confidence in human purification, control and mastery of nature; it shakes one's faith in modernity. Today, yields have at best stabilized in Lot at levels roughly $1 \%$ of historic heights (Callot 1999; Sourzat 2009). Few advocates of modernity would likely claim to establish desirable present conditions at $1 \%$ of past levels. The ugliness in modernity was always implicitly offset with the belief that eventually 
everyone would benefit (Scott 1998; Tsing 2015). Progress was not pretty, supposedly progress would at last arrive and help all those who patiently awaited its arrival.

Tsing (2015) reminds us that without the idea of progress, modernity has little meaning. From the Anthropocene to truffle declines, it seems hard to find progress. Might regress or a directionless ramble be the new story of our time, be it modern, postmodern or whatever term one chooses? The post-WWII economic boom, les trente glorieuses, came and went (Bess 2003). They are now a distance and nostalgic memory. For those who never experienced their benefits, they are left in their wake with wrecked atmosphere, rising wealth inequality and white knuckled right-wing populism that reeks of fascism. Similarly, few alive experienced the truffle's golden age. Now one can drive around Lot amazed by the preponderance of former, now nonproductive truffières. They populate the landscape like unintended monuments to the truffle's "golden age". With so many abandoned and now unproductive truffières, Tsing (2015) might be right that we have no choice but to live in these modernist "ruins" without the hope of finding pure nature, a stable economy or liberating scientific progress.

Without anyone wishing it to be so, the story of post-1930s' trufficulture is one of chaos and regress. Yields, the number of hectares in truffières and the number of trufficulteurs has declined over the last 100 years. The lack of farmers, lost knowledge, increasing wild boar and deer populations, resurging forests and even the climate itself are against trufficulteurs. Co-constituting economic and ecological crisis in general and in trufficulture have ended the what Latour (2010) calls the "short modern parenthesis." Trufficulture is on the other side of that parenthesis with an uncertain future. 
Beyond just the closing of the modern parenthesis for trufficulture, hopes for human control of the climate are farcical when the "revenge of Gaia" awaits us (Latour 2010). Agricultural abandonment, climate change and reforestation have all enacted a similar kind of revenge on trufficulture. It is unlikely that one can merely practice trufficulture as it was a century ago. One surveyed trufficulture doubted that their grandparents' knowledge was useful in the wake of climate change and inoculated plants.

"Novel ecosystems", themselves not manageable on past criteria (Hobbs et al. 2014), are defined if by nothing else other than uncertainty. Precarity rules the day (Tsing 2015). In the case of trufficulture, science and practice are each trying to understand these novel ecosystems in dramatically different and possibly incomprehensible time scales. Even with all the "space-time distanciation" in modernity that revolutionized time-space relationships (Giddens 1984), oak trees have always demanded at least four years of patience by the trufficulteur before producing truffles (Hall et al. 2007; Valserres 1874).

As much as one hopes to at last code the mystery of the truffle, the truffle will demand patience as new techniques are tested. Surveyed trufficulteurs argued that fewer and fewer farmers now have the patience needed to cultivate the truffle. For them, farmers have become too accustomed to annual crops and annual subsides to endure the unpredictability of trufficulture. If they are correct, then not only has the truffle lost virulence (Sourzat 2009), but the people who would need to cultivate it have lost their own kind of virulence. The truffle gained its reputation as being unpredictable and few have actively challenged this idea by daring to try to cultivate it.

Yet all actants are a product of their relations. One can say that the truffle is less virulent in its current actor-networks. On literally the same plots of land in Lot 100 years 
ago it is remarkably virulent. In this dissertation, I have offered the most complete description ever conducted of its passage from virulence to nonvirulence. I followed truffle across time and space, always fearful of losing its traces. Yet, I believe I have tracked down enough of its past actor-networks to imagine new ones. They are a starting point for the "composition of a common world" (Latour 2004) suitable to the truffle.

New actor-networks, for trufficulture and beyond must be assembled. No single actant will be able to control, guide or dominate these new actor-networks. Actants will often be unaware of each other. No single actant will be championed for their success or blamed for their failures. One cannot even assume that humans will maintain a hierarchical position over nonhumans. Humans and nonhumans will relate in inextricable hybrids. All dreams of nature as something separate that can be fully understand and eventually dominated or of a society that is subsumed under kind of laws of nature should be immediately relinquished. The hopes of modernism, many of which were allusions all along, will be sacrificed. One does not need to look back to blame actants. An almost incomprehensible amount of change has occurred, so there is no going backwards. One cannot wait to be lifted upon the wings of progress to a utopic future. Everything relies, as it always has, on the hard and unpredictable work of assembling of actor-networks.

One must pay constant attention to the "missing masses" (Latour 1992) and understand if they must be incorporated. Yet, one must monitor and break with harmful associations and actants. Like trufficulteurs, one must actively maintain actor-networks, but also must be patient to the needs of other actants. One must constantly be observant of association across space and time. Actants will continue to modify spatial and 
temporal scales. One can never expect stability until the work has been done by actants. Ideas of what constitutes actor-network stability will be under regular revision.

These recommendations go beyond trufficulture. A multitude of actor-networks are under rapid, distressing modification. Truth itself is under attack. Yet too much political energy is wasted reacting to such effronteries. There is little conception of anything new, much less movements to realize it. Modernism, its economic, political, legal and social order is still defended by the few whom it still benefits. From frequent economic to ecological crisis, there remains little of comfort for everyone else amidst these "ruins" (Tsing 2015). New actor-networks are necessary. New "progressive compositions of a common world" (Latour 2004:18) are desperately needed. In this dissertation, I have attempted to work with actor-network to do just this for trufficulture. Trufficulture is as good of a place to start as any, but it is just a start. More work is needed to reimagine novel actor-networks for nearly everything else. There is no shortage of work to do now, nor any limits to how fruitful it may be. Now is the time to begin. 


\section{Works Cited:}

\section{Works Cited:}

\section{A. General Works Citied}

Águeda, B., Fernández-Toirán, L. M., \& Martinez-Peña, F. (2010). Ectomycorrhizal status of a mature productive black truffle plantation.

Águeda, B., Zambonelli, A., \& Molina, R. (2014). Tuber 2013: Scientific Advances in Sustainable Truffle Culture,

Akrich, M., Callon, M., Latour, B., \& Monaghan, A. (2002). The key to success in innovation part I: The art of interessement. International Journal of Innovation Management, 6(02), 187-206.

Akrich, M., \& Latour, B. (1992). A Summary of a Convenient Vocabulary for the Semiotics of Human and Nonhuman Assemblies,

Alvarado, P., \& Manjon, J. (2013). A quantitative and molecular examination of tuber melanosporum mycorrhizae in quercus ilex seedlings from different suppliers in spain. Forest Systems, 22(2), 159-169.

Andrés-Alpuente, A., Sánchez, S., Martín, M., Aguirre, Á. J., \& Barriuso, J. J. (2014). Comparative analysis of different methods for evaluating quality. Mycorrhiza, 24(1), S29-S37.

Antony-Babu, S., Deveau, A., Van Nostrand, J. D., Zhou, J., Le Tacon, F., Robin, C., . . . Uroz, S. (2014). Black truffle-associated bacterial communities during the development and maturation of tuber melanosporum ascocarps and putative functional roles. Environmental Microbiology, 16(9), 2831-2847.

Belfiori, B., Riccioni, C., Tempesta, S., Pasqualetti, M., Paolocci, F., \& Rubini, A. (2012). Comparison of ectomycorrhizal communities in natural and cultivated tuber melanosporum truffle grounds. FEMS Microbiology Ecology, 81(3), 547-561.

Bennett, J. (2009). Vibrant matter: A political ecology of things Duke University Press.

Benson, M. C. (2014). The british in rural france: Lifestyle migration and the ongoing quest for a better way of life Oxford University Press.

Bernard, H. R. (2012). Social research methods: Qualitative and quantitative approaches Sage.

Berry, W. (1978). The unsettling of america: Culture \& agriculture. San Francisco: Sierra Club Books. 
Bess, M. (2003). The light-green society: Ecology and technological modernity in France, 1960-2000. University of Chicago Press.

Bonet, J., Fischer, C., \& Colinas, C. (2006). Cultivation of black truffle to promote reforestation and land-use stability. Agronomy for Sustainable Development, 26(1), 6976.

Bonet, J. A., Oliach, D., Fischer, C., Olivera, A., Martinez de Aragon, J., \& Colinas, C. (2009). Cultivation methods of the black truffle, the most profitable mediterranean nonwood forest product; a state of the art review. EFI Proceedings, , 57 57-71.

Bonnet, H. (1869). La truffe: Études sur les truffes comestibles au point de vue botanique, entomologique, forestier et commercial A. Delahaye.

Botkin, D. B. (1990). Discordant harmonies: A new ecology for the twenty-first century. Boulanger, E. (1906). Notes sur la truffe. Lons-Le-Saunier: Lucien Declume.

Bourdieu, P. (1984). Distinction: A social critique of the judgement of taste Harvard university press.

Brillat-Savarin, A. (1825). Physiologie du gout ou, méditations de gastronomie transcendante Michel Lévy frères.

Brunet, R. (1902). Manuel pratique de la culture des champignons et de la truffe:

Champignons... Truffes... L. Mulo.

Büntgen, U., Egli, S., Camarero, J. J., Fischer, E. M., Stobbe, U., Kauserud, H., ... \& Stenseth, N. C. (2012). Drought-induced decline in Mediterranean truffle harvest. Nature Climate Change, 2(12), 827.

Busch, L., \& Juska, A. (1997). Beyond political economy: Actor networks and the globalization of agriculture. Review of International PoIiticaI Economy, 4(4), 688-708.

Byé, P. (2000). Truffle cultivation, 1860-1960: The limits of domestication. Food and Foodways, 9(1), 1-20.

Byé, P., \& Chazoule, C. (1998). Production, protection et profession truffières. Cahiers d'Economie Et De Sociologie Rurales, 46, 131-152.

Callon, M. (1984). Some elements of a sociology of translation: Domestication of the scallops and the fishermen of St Brieuc Bay. The Sociological Review, 32(1_suppl), 196233.

Callon, M. (1999). Actor-network theory-the market test. The Sociological Review, 47, 181-195.

Callon, M. (2006). What does it mean to say that economics is performative? 
Callon, M., \& Latour, B. (1981). Unscrewing the big Leviathan: how actors macrostructure reality and how sociologists help them to do so. Advances in social theory and methodology: Toward an integration of micro-and macro-sociologies, 1 .

Callon, M., \& Latour, B. (1992). Don't throw the baby out with the bath school! A reply to collins and yearley. Science as Practice and Culture, 343, 368.

Callon, M., \& Muniesa, F. (2005). Peripheral vision: Economic markets as calculative collective devices. Organization Studies, 26(8), 1229-1250.

Callot, G. (1999). La truffe, la terre, la vie Editions Quae.

Campbell, C. (2004). Phylloxera: How wine was saved for the world. HarperCollins Publishers.

Castree, N. (2002). False antitheses? marxism, nature and actor-networks. Antipode, 34(1), 111-146.

CBS News. (2012). Truffles: The most expensive food in the world. Retrieved from https://www.youtube.com/watch?v=JUVcxa-wGcE

Chambers, R. (1994). Foreword in beyond farmer first: Rural people's knowledge, agricultural research and extension practice. () Intermediate Technology Publications.

Chambre de commerce et d'industrie. (1994). Histoire de l'économie lotoise. Cahors: Chambre de Commerce et d'Industrie du Lot.

Champagnac, J. (2000). Le paysan et la truffe. Martel, France. Laquet.

Chapin, M., Lamb, Z., \& Threlkeld, B. (2005). Mapping indigenous lands. Annu. Rev. Anthropol., 34, 619-638.

Chatin, A. (1892). La truffe Baillière.

Chauveau, M. (1994). Concots (canton de limogne) (1st ed.). Amiens: Encrage.

Chazoule, C. (2004). L'histoire inachevée de la domestication truffière. Ruralia.Sciences Sociales Et Mondes Ruraux Contemporains, (15)

Chevalier, G., \& Frochot, H. (1997). La maîtrise de la culture de la truffe. Revue Forestière Française, 49, 201-213.

Chevalier, G., \& Pargney, J. C. (2014). Empirical or rational truffle cultivation? it is time to choose. Forest Systems, 23(2), 378-384.

Clarke, J. (2002). A new kind of symmetry: Actor-network theories and the new literacy studies. Studies in the Education of Adults, 34(2), 107-122.

Cullather, N. (2010). The hungry world Harvard University Press. 
De Bosredon, A. (1887). Manuel de trufficulture (1st ed.). Périgueux: Imprimerie E. Laporte.

De la Bellone, Camille de Ferry. (1888). La truffe: Étude sur les truffes et les truffières JB Baillière.

De La Pradelle, M. (2006). Market day in provence University of Chicago Press.

De Laet, M., \& Mol, A. (2000). The zimbabwe bush pump: Mechanics of a fluid technology. Social Studies of Science, 30(2), 225-263.

Diette, S., \& Lauriac, A. (2005). La sylviculture truffière: Aperçus historiques, apports techniques et enjeux pour la région méditerranéenne. For Méditerr, 26(2), 157-168.

Durepos, G., \& Mills, A. J. (2012). Actor-network theory, ANTi-history and critical organizational historiography. Organization, 19(6), 703-721.

Fairhead, J., \& Leach, M. (1996). Misreading the african landscape: Society and ecology in a forest-savanna mosaic Cambridge University Press.

Fine, B. (2005). From actor-network theory to political economy. Capitalism Nature Socialism, 16(4), 91-108.

Fischer, C., \& Colinas, C. (1996). Methodology for certification of quercus ilex seedlings inoculated with tuber melanosporum for commercial application. First International Conference on Mycorrhiza,

Foucault, M. (1984). The foucault reader Pantheon.

FranceAgriMer. (01/23/17). Note TRUFFE (ref : M1669) lundi 23 janvier 2017. Retrieved from http://truffesnoires-lalbenque.com/wp-content/uploads/2017/01/msg16692017-01-23.pdf

Gaignebet, J. (1923). La culture de la truffe dans le causse de martel. Revue De Botanique Appliquée Et d'Agriculture Coloniale, 3(26), 660-666.

Giddens, A. (1984). The constitution of society: Outline of the theory of structuration. Berkeley: University of California Press.

Gioacchini, A. M., Menotta, M., Guescini, M., Saltarelli, R., Ceccaroli, P., Amicucci, A., ... \& Stocchi, V. (2008). Geographical traceability of Italian white truffle (Tuber magnatum Pico) by the analysis of volatile organic compounds. Rapid Communications in Mass Spectrometry, 22(20), 3147-3153.

Goetz, A. F., Wellman, J. B., \& Barnes, W. L. (1985). Optical remote sensing of the earth. Proceedings of the IEEE, 73(6), 950-969.

Goldman, M. J., Nadasdy, P., \& Turner, M. D. (2011). Knowing nature: Conversations at the intersection of political ecology and science studies University of Chicago Press. 
Gomart, E., \& Hennion, A. (1999). A sociology of attachment: Music amateurs, drug users. The Sociological Review, 47(S1), 220-247.

Gregori, G. (2008). Trufficulture en italie: Experiences, problèmes et évolutions possibles. L'avenir De La Truffe Face Au Réchauffement Climatique: La Truffe Européenne Est-Elle En Danger, , 65-76.

Grente, J., \& Delmas, J. (1974). Perspectives pour une trufficulture moderne.

Grimblot, G. A. (1878). Études sur la Truffe. Paris: Imprimerie Nationale.

Groom, G., Mücher, C., Ihse, M., \& Wrbka, T. (2006). Remote sensing in landscape ecology: Experiences and perspectives in a european context. Landscape Ecology, 21(3), 391-408.

Hall, I. R., Brown, G. T., \& Zambonelli, A. (2007). Taming the truffle Timber press.

Haraway, D. J. (2008). When species meet $\mathrm{U}$ of Minnesota Press.

Hecht, S. B., \& Saatchi, S. S. (2007). Globalization and forest resurgence: Changes in forest cover in el salvador. AIBS Bulletin, 57(8), 663-672.

Hobbs, R. J., Higgs, E., Hall, C. M., Bridgewater, P., Chapin, F. S., Ellis, E. C., . . Hulvey, K. B. (2014). Managing the whole landscape: Historical, hybrid, and novel ecosystems. Frontiers in Ecology and the Environment, 12(10), 557-564.

IGN. (05/10/2016). Remonter le temps. Retrieved from https://remonterletemps.ign.fr/.

INSEE. (12/01/2017). Convertisseur franc-euro pouvoir d'achat de l'euro et du franc: Le convertisseur franc-euro mesure l'érosion monétaire due à l'inflation. Retrieved from 2417794

INSEE. (12/10/2017). Comparateur de territoire comparez les territoires de votre choix résultats pour les communes, départements, régions, intercommunalités... Retrieved from https://www.insee.fr/fr/statistiques/1405599?geo=DEP-

46;\%20http://www.bdm.insee.fr/bdm2/affichageSeries?idbank=000067608\&page=graphi que $\&$ codeGroupe $=28 \&$ recherche $=$ idbank

Jensen, J. R. (2009). Remote sensing of the environment: An earth resource perspective 2/e Pearson Education India.

Jensen, J. R., \& Cowen, D. C. (1999). Remote sensing of urban/suburban infrastructure and socio-economic attributes. Photogrammetric Engineering and Remote Sensing, 65, 611-622.

Johnson, J. (1988). Mixing humans and nonhumans together: The sociology of a doorcloser. Social Problems, 35(3), 298-310. 
Kizos, T., Dalaka, A., \& Petanidou, T. (2010). Farmers' attitudes and landscape change: evidence from the abandonment of terraced cultivations on Lesvos, Greece. Agriculture and Human Values, 27(2), 199-212.

Kohler, F., Thierry, C., \& Marchand, G. (2014). Multifunctional agriculture and farmers' attitudes: Two case studies in rural france. Human Ecology, 42(6), 929-949.

Korkmaz, C., \& Türkoğlu, A. (2016). Establishment of truffiere, management and harvest. Mugla Journal of Science and Technology, , 11-12.

Kuhn, T. (2012). The structure of scientific revolutions: 50th anniversary edition (4th ed.). Chicago: University of Chicago Press.

Latour, B. (1983). Give me a laboratory and I will move the world. In K. Knorr, \& M. Mulkay (Eds.), Science observed (pp. 141-170). London: Routledge.

Latour, B. (1984). The powers of association. The Sociological Review, 32(S1), 264-280.

Latour, B. (1987). Science in action: How to follow scientists and engineers through society Harvard university press.

Latour, B. (1988). A relativistic account of einstein's relativity. Social Studies of Science, 18(1), 3-44.

Latour, B. (1990). Drawing things together.

Latour, B. (1990a). Technology is society made durable. The Sociological Review, 38(1_suppl), 103-131.

Latour, B. (1992). "Where are the missing masses? the sociology of a Few Mundane artifacts".

Latour, B. (1993). We have never been modern Harvard University Press.

Latour, B. (1996) Aramis, or, The love of technology. Cambridge, MA : Harvard University Press.

Latour, B. (1996a). On actor-network theory: A few clarifications. Soziale Welt, 369381.

Latour, B. (1999). On recalling ANT. The Sociological Review, 47(S1), 15-25.

Latour, B. (1999). Pandora's hope: Essays on the reality of science studies Harvard university press.

Latour, B. (2004). Politics of nature Harvard University Press.

Latour, B. (2004). Why has critique run out of steam? from matters of fact to matters of concern. Critical Inquiry, 30(2), 225-248. 
Latour, B. (2005). Reassembling the social: An introduction to actor-network-theory Oxford university press.

Latour, B. (2007). To modernize or to ecologize? that is the question. Technoscience: The Politics of Interventions, , 249-272.

Latour, B. (2010). An attempt at a" compositionist manifesto". New Literary History, 41(3), 471-490.

Latour, B. (2013). An inquiry into modes of existence Harvard University Press.

Latour, B. (2014). Agency at the time of the anthropocene. New Literary History, 45(1), 1-18.

Law, J. (1987). Technology and heterogeneous engineering: The case of portuguese expansion. The Social Construction of Technological Systems: New Directions in the Sociology and History of Technology, 1, 1-134.

Law, J. (1992). Notes on the theory of the actor-network: Ordering, strategy, and heterogeneity. Systemic Practice and Action Research, 5(4), 379-393.

Law, J. (2004). After method: Mess in social science research Routledge.

Law, J. (2004a). And if the global were small and noncoherent? method, complexity, and the baroque. Environment and Planning D: Society and Space, 22(1), 13-26.

Law, J. (2009). Actor network theory and material semiotics. The New Blackwell Companion to Social Theory, , 141-158.

Law, J., \& Singleton, V. (2013). ANT and politics: Working in and on the world. Qualitative Sociology, 36(4), 485-502.

Le Tacon, F., Marçais, B., Courvoisier, M., Murat, C., Montpied, P., \& Becker, M. (2014). Climatic variations explain annual fluctuations in french périgord black truffle wholesale markets but do not explain the decrease in black truffle production over the last 48 years. Mycorrhiza, 24(1), 115-125.

Lee, N., \& Brown, S. (1994). Otherness and the actor network: The undiscovered continent. American Behavioral Scientist, 37(6), 772-790.

Loua, T. (1875). Aperçu statistique sur les vignobles européens. Journal de la société française de statistique. 16, 23-28, Société de statistique de Paris.

Martin, F., Kohler, A., Murat, C., Balestrini, R., Coutinho, P. M., Jaillon, O., . . . Percudani, R. (2010). Périgord black truffle genome uncovers evolutionary origins and mechanisms of symbiosis. Nature, 464(7291), 1033.

Mas, J. (1999). Monitoring land-cover changes: A comparison of change detection techniques. International Journal of Remote Sensing, 20(1), 139-152. 
Massumi, B. (2015). The supernormal animal. The Nonhuman Turn, , 1-18.

Mayssonnier, J. (2010). Les hommes de la truffe couraient le monde...1860-1995. Souillac: J.-J. Mayssonnier.

McCarthy, J. (2005). Rural geography: multifunctional rural geographies-reactionary or radical?. Progress in human geography, 29(6), 773-782.

Mello, A., Murat, C., \& Bonfante, P. (2006). Truffles: Much more than a prized and local fungal delicacy. FEMS Microbiology Letters, 260(1), 1-8.

Mendras, H. (1970). The vanishing peasant. innovation and change in french agriculture.

The Vanishing Peasant.Innovation and Change in French Agriculture.,

Mergoil, G,.(1978). Une tentative de reconquête agro-pastorale: Le débroussaillement des causses du quercy. In L. Rietort (Ed.), Espaces fragiles et dynamiques des systèmes agricoles : L'élevage des ovins en france (pp. 253-261). Bordeaux: CERAMAC.

Meulet, J. (1889). Culture de la truffe. Cahors: Imprimerie de Laytou.

Mol, A. (1999). Ontological politics. A word and some questions. The Sociological Review, 47(1_suppl), 74-89.

Mol, A. (2010). Actor-network theory: Sensitive terms and enduring tensions. Kölner Zeitschrift Für Soziologie Und Sozialpsychologie.Sonderheft, 50, 253-269.

Mouillefert, P. (1904). Exploitation et aménagement des bois: Futaies, taillis, trufficulture, abatage et procédés de vidange $\mathrm{F}$. Alcan.

Müller, M. (2015). Assemblages and actor-networks: Rethinking socio-material power, politics and space. Geography Compass, 9(1), 27-41.

Murat, C. (2015). Forty years of inoculating seedlings with truffle fungi: Past and future perspectives. Mycorrhiza, 25(1), 77-81.

Murat, C., Zampieri, E., Vizzini, A., \& Bonfante, P. (2008). Is the perigord black truffle threatened by an invasive species? we dreaded it and it has happened! New Phytologist, 178(4), 699-702.

Murdoch, J. (1998). The spaces of actor-network theory. Geoforum, 29(4), 357-374.

Napoli, C., Mello, A., Borra, A., Vizzini, A., Sourzat, P., \& Bonfante, P. (2010). Tuber melanosporum, when dominant, affects fungal dynamics in truffle grounds. New Phytologist, 185(1), 237-247.

Office du Tourisme de Lalbenque-Limogne. (2017). Marché aux truffes à lalbenque. Retrieved from https://www.lalbenque.net/truffes/march\%C3\%A9s-aux-truffes/. 
Olivier, J., Savignac, J., \& Sourzat, P. (2012). Truffe et trufficulture (2nd ed.) Editions Fanlac.

Patten, M. L. (2016). Questionnaire research: A practical guide Routledge.

Paxton, R. O. (1997). French peasant fascism: Henry dorg? res' greenshirts and the crises of french agriculture, 1929-1939 Oxford University Press.

Pezet, M. A. (1883). Culture de la truffe dans le département du lot. Cahors: Imprimerie F. Delperie.

Pinto-Correia, T., \& Vos, W. (2004). Multifunctionality in Mediterranean landscapespast and future. The new dimensions of the European landscape, 4, 135-164.

Planchon, J. E. (1875). In Delahye A. (Ed.), Les vignes américaines : leur culture, leur résistance au phylloxéra et leur avenir en europe. Paris: Librarie de la faculte de medecine, de l'academie des science et lettres.

Pradel, L. (1914). Manuel de trufficulture. Paris: Baillère et fils.

Ravel, M. (1857). Culture de la truffe. Paris: 18, rue de l'Ancienne-Comédie.

Rebière, J. (1974). La truffe du périgord : Sa culture. (2nd ed.). Périgueux: P. Fanlac.

Rémy, J. (1861). Champignons et truffes. Paris: Librarie Agricole de la Maison Rustique.

Renwick, A., Jansson, T., Verburg, P. H., Revoredo-Giha, C., Britz, W., Gocht, A., \& McCracken, D. (2013). Policy reform and agricultural land abandonment in the EU. Land Use Policy, 30(1), 446-457.

Rindfuss, R. R., \& Stern, P. C. (1998). Linking remote sensing and social science: The need and the challenges. People and Pixels: Linking Remote Sensing and Social Science, , 1-27.

Robbins, P. (2001). Tracking invasive land covers in india, or why our landscapes have never been modern. Annals of the Association of American Geographers, 91(4), 637-659.

Robbins, P. (2012). Lawn people: How grasses, weeds, and chemicals make us who we are. Temple University Press.

Rubini, A., Belfiori, B., Riccioni, C., Arcioni, S., Martin, F., \& Paolocci, F. (2011). Tuber melanosporum: Mating type distribution in a natural plantation and dynamics of strains of different mating types on the roots of nursery-inoculated host plants. New Phytologist, 189(3), 723-735.

Rudy, A. P., \& Gareau, B. J. (2005). Actor-network theory, marxist economics, and marxist political ecology. Capitalism Nature Socialism, 16(4), 85-90. 
Samils, N., Olivera, A., Danell, E., Alexander, S. J., Fischer, C., \& Colinas, C. (2008). The socioeconomic impact of truffle cultivation in rural Spain1. Economic Botany, 62(3), 331.

Savignac, J. (2008). Allocution d'ouverture. In Y. Rousset-Rouard (Ed.), L'avenir de la truffe: Face au réchauffement climatique (1st ed., pp. 21). Paris: Albin Michel.

Scoones, I. (1999). New ecology and the social sciences: what prospects for a fruitful engagement?. Annual review of anthropology, 28(1), 479-507.

Scott, J. C. (1998). Seeing like a state: How certain schemes to improve the human condition have failed Yale University Press.

Shaviro, S. (2015). Consequences of panpsychism. The Nonhuman Turn, , 19-44.

Sol, E. (1980). Le vieux quercy (tome 1) : Usages anciens. Cahors: Bibliothèque de la Maison des oeuvres Cahors.

Souperbie, T. (2014). La première guerre mondiale et la légion d'Honneur dans le lot. Retrieved from http://medialot.fr/la-premiere-guerre-mondiale-et-la-legion-dhonneurdans-le-lot/

Sourzat, P. (1994). Guide pratique de trufficulture. station d'experimentation sur la truffe.

Sourzat, P. (2009). The truffle and its cultivation in france. Acta Botanica Yunnanica, Supplement XVI, , 72-80.

Splivallo, R., Rittersma, R., Valdez, N., Chevalier, G., Molinier, V., Wipf, D., \& Karlovsky, P. (2012). Is climate change altering the geographic distribution of truffles?. Frontiers in Ecology and the Environment, 10(9), 461-462.

Star, S. L. (1990). Power, technology and the phenomenology of conventions: On being allergic to onions. The Sociological Review, 38(S1), 26-56.

Stobbe, U., Egli, S., Tegel, W., Peter, M., Sproll, L., \& Büntgen, U. (2013). Potential and limitations of Burgundy truffle cultivation. Applied microbiology and biotechnology, 97(12), 5215-5224.

Streiblová, E., Gryndlerová, H., \& Gryndler, M. (2012). Truffle brûlé: An efficient fungal life strategy. FEMS Microbiology Ecology, 80(1), 1-8.

Sundberg, J. (2014). Decolonizing posthumanist geographies. Cultural Geographies, 21(1), 33-47.

Syndicat des trufficulteurs de Lalbenque. (2016). Apports \& cours 2015-2016. Retrieved from http://truffesnoires-lalbenque.com/marches/cours-2015-2016/ 
Taylor, P. J. (2011). Agency, structuredness, and the production of knowledge within intersecting processes. Knowing nature: conversations at the intersection of political ecology and science studies, 81-98.

Therville, C., Mangenet, T., Hinnewinkel, C., Guillerme, S., \& De Foresta, H. (2013). Is truffle growing a response to sustainable development and heritage issues in Mediterranean territories? The case of Uzès, southern France. Forests, trees and livelihoods, 22(4), 257-274.

Tongco, M. D. C. (2007). Purposive sampling as a tool for informant selection. Ethnobotany Research and applications, 5, 147-158.

Toujas-Pinède, C. (1954). L'émigration des habitants du lot en amérique du sud à la fin du XIXe siècle. Revue Géographique Des Pyrénées Et Du Sud-Ouest, 25(4), 277-292.

Tsing, A. L. (2011). Friction: An ethnography of global connection. Princeton University Press.

Tsing, A. L. (2015). The mushroom at the end of the world: On the possibility of life in capitalist ruins Princeton University Press.

Turner, W., Spector, S., Gardiner, N., Fladeland, M., Sterling, E., \& Steininger, M. (2003). Remote sensing for biodiversity science and conservation. Trends in Ecology \& Evolution, 18(6), 306-314.

Valserres, J. (1874). Culture lucrative de la truffe pour le reboisement. Paris: Librarie de la Société des gens de lettres.

Velasco-Graciet, H., \& Rouvellac, E. (2003). Le vignoble de cahors au temps de l'économie-monde. Les Vignobles Du Sud-Ouest Européen Dans La Mondialisation, (14), 87.

Viré, A. E. E. (1907). Le lot, padirac, rocamadour, lacave, guide du touriste, du naturaliste et de l'archéologue. Paris: Masson.

Walsham, G. (1997). Actor-network theory and IS research: current status and future prospects. In Information systems and qualitative research (pp. 466-480). Springer, Boston, MA.

Wedén, C., Danell, E., \& Tibell, L. (2005). Species recognition in the truffle genus Tuber-the synonyms Tuber aestivum and Tuber uncinatum. Environmental Microbiology, 7(10), 1535-1546.

Whittle, A., \& Spicer, A. (2008). Is actor network theory critique? Organization Studies, 29(4), 611-629.

Winner, L. (1980). Do artifacts have politics? Daedalus, , 121-136. 
Yates-Doerr, E., \& Mol, A. (2012). Cuts of meat: Disentangling western natures-cultures. The Cambridge Journal of Anthropology, 30(2), 48-64.

\section{B. Archival Works Cited}

Baux, É. (1982). Agriculture et vie rurale en quecy au XIX siècle: 1789:1914 (1st ed.). Cahors: Archives du Lot: Services Educatif.

Baynac, J. (1971). La crise phylloxérique et ses conséquences dans le canton de luzech (lot). (Unpublished Doctorate). Université de Toulouse, Université de Toulouse. (BR 1 729)

Castelnau, E. (1978). Le truffe dans le lot. (Unpublished Masters). Université de Toulouse, Université de Toulouse. (BR 1744 )

Comité départemental de production et d'Equipment agricoles: procès-verbaux des séances. (1952). Investissements agricoles : Programmes 1948-1952 (récapitulation). ( No. 1 W 391). Cahors: Comité départemental de production et d'Equipment agricoles: procès-verbaux des séances.

Conservateur des Eaux et Fores au Conseil Général. (1933). Rapports du conservateur des eaux et fores au conseil général 1901-33. ( No. 4 M 53). Cahors: Conservateur des Eaux et Fores au Conseil Général.

Correspondance et rapports. (1894). Apparition et traitement de la maladie: Circulaires et instructions, documentation, administratives et scientifiques (1871-1890). ( No. $7 \mathrm{M}$ $56)$.

De Lamberterie, M. L. (1856). Études sur le département du lot . ( No. BR 3 art. 1109). Paris: Impremerie Adminstrative de Paul Dupont.

De Lamberterie, M. L. (1874). Études sur le département du lot . ( No. BR 2 1414). Paris: Impremerie Adminstrative de Paul Dupont.

De Lamberterie, M. L. (1880). Études sur le département du lot (3rd ed.). Cahors: Imprimerie de A. Laytou.

Delpon, J. -. (1831). Statistique du département du lot. (No. Tome II). Paris: Libraire Bachelier.

Département du Lot. (1860). Statistiques agricoles pour les communes de l'arrondisement de Cahors 1856-1860. ( No. 6 M 384). Cahors: Département du Lot.

Département du Lot. (1862). Statistiques agricoles annuelles arrondissement of gourdon 1852-1862. Cahors: Département du Lot.

Département du Lot. (1882). Statistiques agricoles pour les communes de l'arrondissement de cahors 1882. (No. 6 M 385).Le département du Lot. 
Département du Lot. (1886). Recensement de 1886; état récapitulatif sommaire; tableau général de la population; divers états récapitulatifs. (No. 6 M 16). Cahors: Le Département du Lot.

Département du Lot. (1900). Statistiques agricoles annuelles arrondissement of gourdon 1896-1900. (No. 6 M 437). Cahors: Le département du Lot.

Département du Lot. (1907). Statistiques agricoles annuelles arrondissement of gourdon 1904-07. (No. 6 M 440). Cahors: Département du Lot.

Département du Lot. (1908). Enquête sur les dégâts causes aux truffières par les troupeaux 1908. (No. 7 M 80). Cahors: Le Département du Lot.

Département du Lot. (1911). Statistiques agricoles annuelles arrondissement of gourdon 1908-1911. (No. 6 M 441). Cahors: Département du Lot.

Département du Lot. (1912). Phylloxera 1876-1912. Enquêtes annuelles sur le phylloxera étendu des vignobles attaques, détruits, traites. (No. 7 M 58). Cahors: Département du Lot.

Département du Lot. (1915). Statistiques agricoles annuelles arrondissement of Gourdon 1912-1915. (No. 6 M 442). Cahors: Le département du Lot.

Le département du Lot. (1918). Sous-comité consultatif d'action économique du lot: Rapports, procès-verbaux des réunions 1916-1918. (No. 6 M 377). Cahors: Le Département du Lot.

Le département du Lot. (1918). Statistiques agricoles annuelles arrondissement of gourdon 1916-1918. (No. 6 M 443). Cahors: Le département du Lot.

Département du Lot. (1931). Statistiques agricoles : Tableaux récapitulatifs pour l'ensemble du département: 1885-1931. ( No. 6 M 450). Cahors: Département du Lot.

Département du Lot. (1934). Statistiques agricoles annuelles arrondissement of gourdon 1938-39. (No. 6 M 449). Cahors: Le département du Lot.

Département du Lot. (1939). Relevés des déclarations pour les récoltes de 1934 et 1936, rapport du directeur des services agricoles sur la récolte de 1939. ( No. 7 M 63). Cahors: Département du Lot.

Direction Départemental de l'Agriculture du Lot Service du Génie Rural des Eaux et des Forest. (1969). Le Causse de Gramat Aménagement et Développement: Analyse Tome 1. Cahors.

Gay, L., \& Gromas, R. (1937). Monographie agricole du département du lot (1st ed.). Cahors: Impremerie Coueslant. 
Gluck, J., \& Gluck, E. (1852). Album historique du département du lot: Avec les vues des principaux monuments et sites de cette partie du quercy Gluck.

Hermet, M. (2002). Le phylloxera et ses conséquences sur le vignoble de la vallée du lot. (Unpublished Doctorate). Université de Toulouse, Toulouse.

Larue, P. (1906). Le quercy: Aperçus agronomiques sur le département du lot. ( No. BR 2 44). Toulouse: Chez L'auteur.

Le Centre de Gestion et D'Economie Rurale du Lot. (1963). Causses du lot: Perspectives de remise en valeur D'un group D'ExploitationsCaussenards. ( No. BR 2 590). Cahors: Chambre D'Agriculture du Lot.

Ministère d'Etat, Ministère de L'intérieur. (1975). Ministère d'Etat, ministère de L'intérieur recensement général de la population de 1975: Population du département $d u$ lot arrondissement, cantons et communes. ( No. BR 144 ). Cahors: Ministère d'Etat, Ministère de L'intérieur.

Ministère de L'agriculture. (1869). Enquête agricole . ( No. 1 180). Paris: Impremerie Imperial.

Ministère de L'agriculture. (1959). Monographies agricoles départementales: 46 le lot. ( No. BR 576). Paris: La Documentation Française.

Ministère de L'agriculture. (1973). La reconversion de la population agricole active dans le département du lot entre 1967 et 1970. ( No. BR 1 37). Cahors: Ministère de L'agriculture.

Ministère de L'agriculture et de La Foret. (1988). La statistique agricole. recensement agricole 1988 lot: Principaux résultat. (). Toulouse: Ministère de L'agriculture et de La Foret.

Ministère de l'agriculture et de la foret. (1992). La statistique agricole : Annuaire 1992 région midi-pyrénées. (). Toulouse: Ministère de l'agriculture et de la foret.

Ministère de 1'agriculture et de la foret. (2002). La statistique agricole annuaire 2002: Sélection de données sur le monde agricole, forestier et agro-alimentaire de midipyrénées. Toulouse: Ministère de l'agriculture et de la foret.

Rey, E. (1889). L'agriculture progressive dans le lot (1st ed.). Cahors: J. Girma.

Rey, E. (1908). L'agriculture progressive dans le lot (2nd ed.). Cahors: J. Girma.

Service de l'Aménagement Foncier et Forestier. (1964). La foret dans le département du lot. (No. BR 1 888). Cahors: Service de l'Aménagement Foncier et Forestier. 
Société Française de Protection Contre le Phylloxera. (1912). Enquetes annuelles sur le phylloxera etendu des vignobles attaques, detruits, traites 1876-1912. ( No. 7 M 58).

Cahors: Société Française de Protection Contre le Phylloxera.

Toujas-Pinede, C. (1994). La population du lot de 1801-1975. Toulouse: Rene Toujas.

Toujas-Pinède, C. (1990). L'immigration étrangère en quercy: Aux XIXe et XXe siècles Privat.

C. Survey Interviews Cited

Trufficulteur \#1, personal communication, 07/19/2016.

Trufficulteur \#2, personal communication, 08/06/2015.

Trufficulteur \#3, personal communication, 08/06/2015.

Trufficulteur \#4, personal communication, 08/05/2015.

Trufficulteur \#5, personal communication, 08/05/2015.

Trufficulteur \#6, personal communication, 07/30/2015.

Trufficulteur \#7, personal communication, 07/31/2015.

Trufficulteur \#8, personal communication, 07/30/2015.

Trufficulteur \#9, personal communication, 07/30/2015.

Trufficulteur \#10, personal communication, 08/07/2015.

Trufficulteur \# 11, personal communication, 07/10/2015.

Trufficulteur \#12, personal communication, 07/16/2015.

Trufficulteur \#13, personal communication, 07/08/2015.

Trufficulteur \#15, personal communication, 07/16/2015.

Trufficulteur \#16, personal communication, 07/16/2015.

Trufficulteur \#17, personal communication, 07/16/2015.

Trufficulteur \#18, personal communication, 07/01/2014.

Trufficulteur \#19, personal communication, 07/04/2014. 
Trufficulteur \#20, personal communication, 07/04/2014.

Trufficulteur \#21, personal communication, 07/16/2014.

Trufficulteur \#22, personal communication, 07/17/2014.

Trufficulteur \#23, personal communication, 07/17/2014.

Trufficulteur \#24, personal communication, 07/18/2014.

Trufficulteur \#25, personal communication, 07/18/2014.

Trufficulteur \#26 personal communication, 08/12/2014.

Trufficulteur \#27, personal communication, 08/12/2014.

Trufficulteur \#28, personal communication, 08/12/2014.

Trufficulteur \#29, personal communication, 08/13/2014.

Trufficulteur \#30, personal communication, 08/13/2014.

Trufficulteur \#31, personal communication, 08/13/2014.

Trufficulteur \#32, personal communication, 08/14/2014.

Trufficulteur \#33, personal communication, 07/16/2014.

Trufficulteur \#34, personal communication, 08/14/2014.

Trufficulteur \#35, personal communication, 08/14/2014.

Trufficulteur \#36, personal communication, 01/24/2015.

Trufficulteur \#37, personal communication, 01/21/2015.

Trufficulteur \#38, personal communication, 01/21/2015.

Trufficulteur \#39, personal communication, 01/25/2015.

Trufficulteur \#40, personal communication, 01/09/2015.

Trufficulteur \#41, personal communication, 01/08/2015.

Trufficulteur \#42, personal communication, 01/07/2015. 
Appendix 1:

Trufficulture's Ecological, Economical and Sociological Role in the Territorial Dynamics of Lot, France $\underline{\text { Study Project Complete by Eric Van Vleet }}$

(for a doctorate in Geography from Florida International University, United States)

Date of Survey:

General Personal Data:

Name/Last Name:

Address/Town:

What is your age?

Where were you born?

\section{Truffle Ecology}

Introduction: These questions regarding the ecology of the truffle seek to understand the place that trufficulture has in landscapes, how it is currently practiced in Lot. These questions seek to understand the use of mycorrhized/inoculated plants, the effects of climate change on trufficulture as well others positive or negative environmental effects.

1. How long have you had a truffière or how long have you been a trufficulteur?

2. How many hectares of truffières do you have?

3. At what age did your plantations begin to produce?

4. What percentage of your trees produce in your plantation?

5. In what state were your lands before they became a truffière (arable land, fallows, forests etc.)?

6. What species of trees have you planted? Did you plant certified mycorrhized plants? Why did you choose these species (Quercus pubescens, Q. ilex, Q. cerris, Q. coccifera, Corylus avellane, C. colurna and Carpinus betulus)?

7. Do you believe that mycorrhized trees are better than trees created on site like those that were planted in the past?

8. Did you examine your soil ( $\mathrm{pH}$ analysis, pedological profile) before planting your truffière? Did you change your soil (amendments, crushing rocks)? How?

9. Have you harvested other species of truffles other than Tuber melanosporum? (Tuber brumale, Tuber aestivum, Tuber rufum, Tuber excavatum, etc) Do you think these other 
species are problematic, especially because of fungal contamination or fungal competition?

10. Do you believe in climate change? If so, has climate change had an influence on truffle production? Could you explain how climate change has affected Tuber melanosporum truffles (too much rain in the spring, summer droughts that destroy young truffles, sustained freezes in winter that damage truffles, etc.?)

11. Have you changed your trufficulture techniques because of climate change? How?

12. What other challenges or ecological problems in your point of view influence truffle production (wild animals such as wild boar or deer, acid rain, etc.)?

\section{The Truffle Economy}

Introduction: Truffle production seems to have contributed to the territorial economy. We should envision this economy at once with the direct impacts of trufficulture (plantations, their maintenance and the sale of truffles and indirect effects (agritourism, restaurants and lodging).

1. Are subsidies important for trufficulture? What kinds of subsidies aid trufficulteurs?

2. Do you think that trufficulteurs are sufficiently subsidized from public or other funds? Have you personally already benefited from public aid for your truffle plantations?

3. Do you have plans to enlarge your plantations?

4. Have you had problems with truffle thieves? Have you done anything to protect your truffières?

5. Do you believe Lalbenque's truffles (or Lot's or Quercy's) deserve an appellation d'origine contrôlée? Why or why not?

6. Is Lalbenque's truffle different than those of Provence or Spain? If so, how would you explain this difference (the gustative qualities are better in Lalbenque, the aroma of Lot's truffles are more subtle or intense, harvested truffles are at their peak maturity).

7. Do tourists interested in the truffle participate in Lalbenque's local economy or that of Southern Lot, or Lot in general? How? (They are interested in trufficulture, in buying truffles, in going to restaurants to consume truffles, in visitant trufficulteurs, etc.?)

8. In your case, is the trufficulteur is a supplementary or additional source of revenue?

9. Do you have another source of revenue other than trufficulture?

\section{The Relaunch of Truffle Production}

Introduction: Truffle production has seen a period of progressive decline after the first World War that continued throughout the $20^{\text {th }}$ century. Many hypotheses exist for the reason(s) of this decline. We also focus here on truffle associations and syndicates, public support and the work of the experimental truffle station at Le Montat and its efforts over the last 40 years to relaunch truffle production in Lot and France. 
1. Why has Tuber melanosporum production declined? Among these options, which seem to be the most plausible?

a). Loss of knowledge and techniques, b). Declines in the uses of fuelwood, c)

Mechanization of agriculture, d) Decline in rural populations, e) Lack of scientific knowledge, f) Preference for viticulture, g) Climate change, h) invasion of other truffle species, i) low prices for Tuber melanosporum, j) CAP subsidies, k) preference for other crops.

2. How did you learn trufficulture? Who taught you?

3. Do you think older trufficulteurs have shared their knowledge and techniques? How? 4. Near your truffière, is there a farm that commonly uses pesticides or herbicides? Do you think these applications have a positive or negative on truffle production? What other agricultural practices could influence Tuber melanosporum production (viticulture, sunchokes, lavender, etc.?).

5. Do you think that there are fewer and fewer farmers engaged in agriculture? Do you think that access to agricultural retirement funds (to either rent or sell your lands) penalize trufficulture? Do you think that CAP per hectare subsidies hurt initiatives for farmers to develop trufficulture?

6. What are the most common reasons for becoming a trufficulteur (complementary revenue, the valuing of patrimony, memories of childhood such as looking for truffles with your parents or grandparents?

7. Do you have any other hypothesis to help explain declines in Tuber melanosporum during the $20^{\text {th }}$ century?

8. Do you belong to a truffle association or syndicate? Which one? Since when? Is it important to participate in such associations to help trufficulture progress? Why (because you can exchange results, to learn other methods of trufficulture, better sell your production, increased conviviality, etc.)?

9. Do you subscribe to a technical or professional trufficulture magazine? Which one(s) (the French trufficulteur, Trifficulteurs from the Causses du Quercy and the MidiPyrenees region?

10. Are you familiar with the truffle experiments carried out by the truffle research station at Le Montat? Have you received technical advice from the truffle research station at Le Montat? Do you wish to receive technical advice from them?

11. About which subjects should Le Montat conduct research (quality of truffle plants, maintenance of truffle plantations, irrigation in a truffière, pruning of trees, which crops improve truffières, the restoration of former truffières?

12. Is there anything else you would like to say about the truffle, notably about subject of which we have not mention? How do you feel about the future of the truffle? 
VITA

ERIC VAN VLEET

Contact details: $2454 \mathrm{Na}$ Wa Ka Drive, Marinette WI, 54143.

T: 786-245-5243; mail:

eevanvleet@gmail.com

Education and Career History

08/2013-Current Florida International University

PhD Geography

01/2011-05/2015 Florida International University

GIS Graduate Certificate

08/2011-05/2013 Florida International University

MA Environmental Studies

09/2003-05/20005 University of Wisconsin-Madison

BA Journalism

09/2001-05/2003 University of Wisconsin-Marinette

Associate's Degree

08/2011-12/2017 Florida International University

Teaching Assistant

- Researching, preparing and presenting PowerPoint presentations on South Florida ecology

- Organizing and supervising field trips to local protected areas

- Writing questions and grading quizzes

- Maintaining class pages in both Moodle and Blackboard for online learning

- Scheduling and maintaining office hours to address student concerns.

06/2017-09/2017 Rocky Mountain National Park (seasonal assignment) Interpretative Park Ranger:

- Researched, created and presented environmental education programs to the public

- Provided formal and informal interpretation in English, French and Spanish

- Created active environmental education for children aged 412 
- Led educational walks with groups of 2-20 members of the public

09/2008-05/2009; 09/2009-05/2010 CEDEI

English Teacher

- Planned, designed and implemented English lessons

- Assigned and graded homework and submitted final grades

- Incorporated video, audio and games in lessons

- Utilized immersion teaching techniques at all levels

- Taught group as well as individual classes

- Students levels ranged from intermediate to advanced

10/2008-04/2009 La Casa de la Mujer

Co-founder, Teacher:

- Co-founded program providing free English classes to local artisans

- Worked with local partners to develop this program

- Planned, developed and implemented lessons for beginners

- Explained grammar points in both English and Spanish

- Recruited other native speakers for this volunteer program

Calserves

Mentor/AmeriCorps Volunteer

- Planned and implemented lessons on reading fluency and comprehension

- Tutored individual students from first to sixth grade

- Conducted regular assessments to verify their progress

- Served as an afterschool teacher for 20 fifth-grade students

- Organized reading and math lessons for after-school students

- Communicated with students' parents and homeroom teachers

Research Projects

Knowing but Not Knowing: Systematic Conservation Planning in Oaxaca, Mexico

- Conducted ethnographic fieldwork in seven indigenous communities in Oaxaca,

- Mexico

- Analyzed remotely sensed images to understand land cover changes over time 
- Conducted semi-structured group interviews with community leaders

- Arranged guided walks with community leaders to understand agricultural uses

- Research drove the completion of master's thesis

The Truffle Was Never Modern: 150 Years of French Trufficulture

- Conducted nine months of archival research in Lot's départemental archives

- Analyzed historical aerial images to understand land use and cover changes

- Conducted semi-structured survey interviews with truffle growers

- Attended meetings with truffle associations and syndicates

- Conducted participant observation at truffle markets and museums

\section{PEER-REVIEWED PUBLICATIONS}

Van Vleet, E., Bray, D. B., \& Durán, E. (2016). Knowing but not knowing: Systematic conservation planning and community conservation in the Sierra Norte of Oaxaca, Mexico. Land Use Policy, 59, 504-515. 